\title{
Go-ahead men: Yankee Westerners test masculine bonds in the early American republic
}

\author{
Charlotte Cathy Rodabaugh \\ West Virginia University
}

Follow this and additional works at: https://researchrepository.wvu.edu/etd

\section{Recommended Citation}

Rodabaugh, Charlotte Cathy, "Go-ahead men: Yankee Westerners test masculine bonds in the early American republic" (2011). Graduate Theses, Dissertations, and Problem Reports. 4774.

https://researchrepository.wvu.edu/etd/4774

This Dissertation is protected by copyright and/or related rights. It has been brought to you by the The Research Repository @ WVU with permission from the rights-holder(s). You are free to use this Dissertation in any way that is permitted by the copyright and related rights legislation that applies to your use. For other uses you must obtain permission from the rights-holder(s) directly, unless additional rights are indicated by a Creative Commons license in the record and/ or on the work itself. This Dissertation has been accepted for inclusion in WVU Graduate Theses, Dissertations, and Problem Reports collection by an authorized administrator of The Research Repository @ WVU.

For more information, please contact researchrepository@mail.wvu.edu. 
GO-AHEAD MEN: YANKEE WESTERNERS

TEST MASCULINE BONDS IN

THE EARLY AMERICAN REPUBLIC

\author{
Charlotte (Cathy) Rodabaugh \\ Dissertation submitted to the \\ Eberly College of Arts and Sciences \\ at West Virginia University \\ in partial fulfillment of the requirements \\ for the degree of \\ Doctor of Philosophy \\ in \\ History \\ Approved by \\ Kenneth Fones-Wolf, Committee Chairperson \\ Brian Luskey \\ Michal McMahon \\ Katherine Aaslestad \\ James Brewer Stewart \\ Department of History \\ Morgantown, West Virginia \\ 2011
}

Keywords: Symmes, Giddings, abolition,

Bleeding Kansas, manhood, self-made man

Copyright 2011 Charlotte (Cathy) Rodabaugh 


\author{
Abstract \\ GO-AHEAD MEN: YANKEE WESTERNERS \\ TEST MASCULINE BONDS IN THE \\ EARLY AMERICAN REPUBLIC \\ by Charlotte (Cathy) Rodabaugh
}

Colonial New England fathers normally launched sons' careers, often aided by other male relatives. However, economic developments in the early American republic rendered sons' expectations less sure even as Americans began celebrating the concept of the self-made man and pressured young men to distinguish themselves. Even worse, they asserted that success or failure signaled more about the man than about his particular circumstances. This study delves into some close male relationships through which were negotiated these tensions between cultural expectations and reality. Scholars describe the rise of a distinctly Northern, middle-class manhood, but this project isolates how the relationships that undergirded it functioned for individual men propelled toward imagined opportunities in the emerging West, where the fabled "Yankee go-ahead" might achieve its purest expression. It corrects an overemphasis on Eastern urban centers and also challenges a prevailing view that a cultural celebration of individualism reflecting broad changes underway was exemplified by hordes of ambitious, competitive young men eager to try their hands at self-fashioning. If this research is indicative, often a circle of close male associates surrounded and protected aspiring men from suffering the full potential brunt of the competitive marketplace. Three chapters examine case studies involving Northwest Territory Judge John Cleves Symmes, Western Reserve abolitionist Joshua Giddings, and Bleeding Kansas participant Oscar Learnard. All three had New England backgrounds and ideas about what roles close male associates might play in the lives of young men hoping for a launch into adulthood. They also had a boundless supply of ambition and viewed the developing West as the place to unleash it: they were go-ahead men. 


\section{DEDICATION}

The author dedicates this work to her husband, Stephen Rodabaugh, for his boundless support, and to the memory of her father, Bert Earls. 


\section{ACKNOWLEDGMENTS}

I owe thanks to numerous individuals or institutions without whose assistance this work would have never seen completion. Foremost, my husband Stephen Rodabaugh's enthusiasm and patience never flagged for a moment, even when it meant my prolonged absence from home-and from reliable income production. My sister Patricia Earls Lucy selflessly oversaw the care of our elderly parents in a distant state so conscientiously that I could stay on task during times when I knew I should have been in Kansas with her. The history faculty at Youngstown State University was engaged and encouraging, especially Diane Barnes, in whose graduate class this project began. On her prodding, an academic neophyte introduced herself at a conference to Jim Stewart, who quickly became the Giddings study's unofficial shepherd, and a source of priceless advice and encouragement. Raymond Krohn is a graduate program office-mate turned son-inlaw who is also patience personified, and has spent hours reading or discussing parts of this project. Stacey Robertson sent me her unpublished book manuscript and Rachel Doddato of the Sutliff Museum allowed me to read the un-accessioned Sutliff papers. James Hilston's invaluable technical assistance rescued me at just the right time.

Numerous institutions opened their archives to me and their staffs provided on site support or copying, for which I am grateful. Those include the Western Reserve Historical Society (Cleveland), Sutliff Museum (Warren, Ohio), Maag Library of Youngstown State University (Youngstown, Ohio), West Virginia University/Special Collections (Morgantown, West Virginia), Spencer Research Library of Kansas State University (Lawrence, Kansas), Antiquarian Society (Worcester, Massachusetts), Firestone Library of Princeton University (Princeton, New Jersey), Library Company (Philadelphia), Abraham Lincoln Presidential Library (Springfield, Illinois), Indiana Historical Society (Indianapolis), Indiana State Library (Indianapolis), Kansas Historical Society (Topeka, Kansas), Clements 
Research Library (Ann Arbor, Michigan), Library of Congress (Washington D.C.), Newberry Library (Chicago), Vermont Historical Society (Barre, Vermont), Gilder Lehrman Institute of American History (New York City), Filson Historical Society (Louisville), Winterthur Estate and Research Library (Wilmington, Delaware), and Kreitzberg Library of Norwich University (Northfield, Vermont).

Several of those institutions funded my visits by way of research fellowships: Gilder Lehrman Institute of American History, Vermont Historical Society, Winterthur Estate, and Filson Historical Society. Additional funding came through awards from Colonial Dames of America, the Stuart and Joyce Robbins Fellowship, the Wesley M. Bagby Award, WVU Department of History, WVU Graduate Office, WVU Graduate Education and Life, and the Eberly College of Arts and Sciences. In addition, the WVU Department of History helped fund numerous trips for conferences or research through departmental grants.

All three case studies evolved over time and were presented in various forms at numerous conferences. The feedback of commentators and attendees has improved each one. Carol Lasser opened a fresh vista for the Giddings study when she suggested I look into the circumstances surrounding Giddings's marriage and the birth of his first child.

It is impossible to overstate the value of a supportive department. The Department of History at West Virginia University repeatedly exceeded my expectations in encouragement, provision, hospitality, and collegiality. Graduate director/Chairperson Steve Zdatny and Chairperson Elizabeth Fones-Wolf each seemed magically to make potential obstacles disappear. Two of my case studies originated in seminar classes of Mary Lou Lustig and Kenneth Fones-Wolf. I appreciate tremendously the input and patience of my exam and defense committees: Kenneth Fones-Wolf, Mary Lou Lustig, Michal McMahon, Brian Luskey, Katherine Aaslestad, James Brewer Stewart, and Diane Barnes. Somehow, Martha May solves our innumerable problems with her incomparable 
patience and good nature. Finally, it would be hard to overstate what an outstanding advisor Ken Fones-Wolf has been. He helped me envision separate studies as a coherent dissertation topic and was an unending source of valuable guidance on research or funding strategies. He normally set me loose to do my own thinking, but reined me in when my preoccupation for solving every last question threatened to derail every deadline we set-and re-set. For the generous guidance, patience, friendship, and example of Ken (and Liz), I will always be grateful. 


\section{TABLE OF CONTENTS}

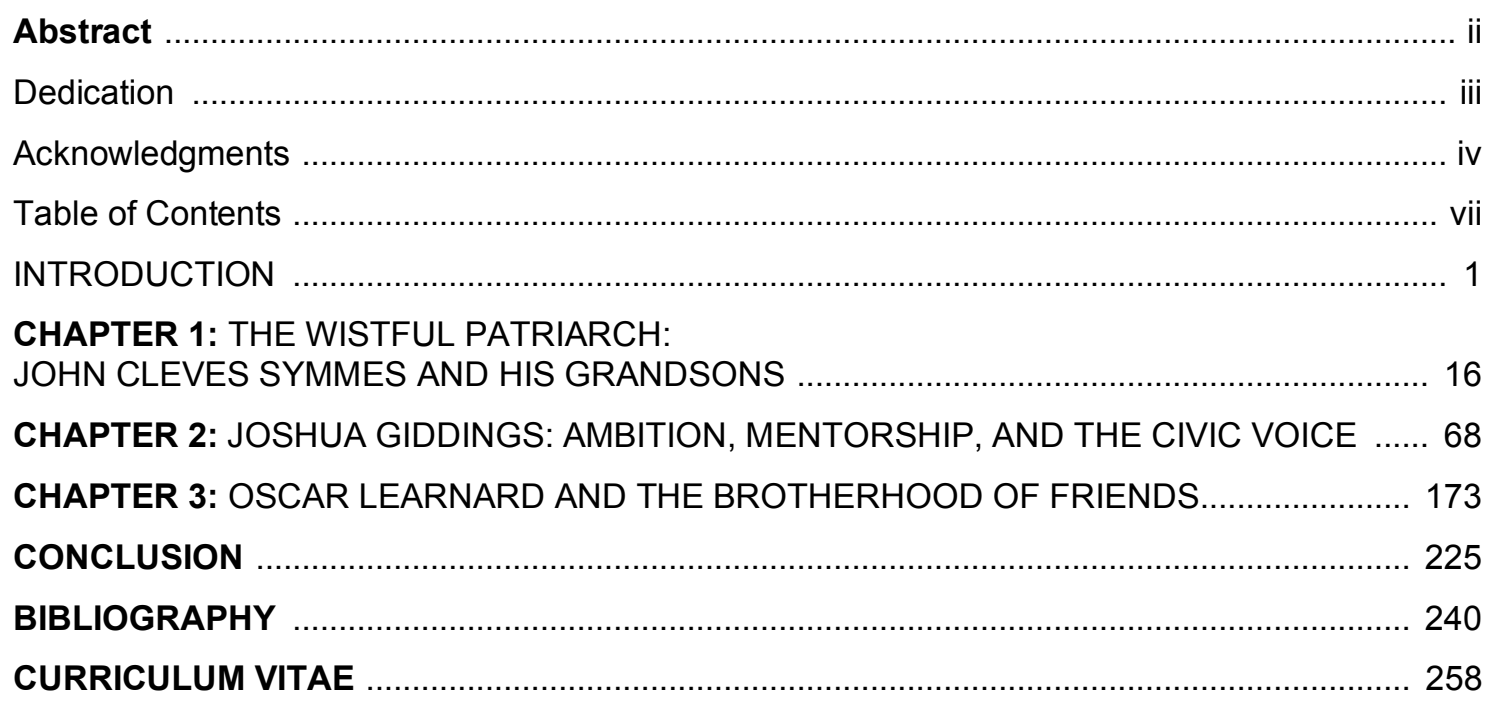




\section{INTRODUCTION}

When the earliest strains of what became the devastating Panic of 1837 hit the United States, Nathaniel Hawthorne was just getting his bearings at the American Magazine of Useful and Entertaining Knowledge, where he was both editor and primary contributor. The magazine's founders believed Americans could benefit generally from learning more about "our own fine and native country." By 1837 proper, this brooding romantic, so identified later with New England tales of deep introspection and moral dilemma, recognized his suffering national kinsmen needed encouragement, as well as entertainment. ${ }^{1}$

Despite the plebian nature of his current employment, Hawthorne, like other nineteenth-century New England literati, still reflected a belief that exceptional wisdom tended to emanate from their corner of the nation. Hawthorne included in his third issue a short article about Maine promoting its inhabitants as the exemplary possessors of the American can-do spirit. They had, it read,

long been distinguished for their hardihood and enterprise, their shrewdness, economy, industry, and public spirit ... . [A]lthough they may encounter reverses to-day, like 'true Yankees' they are 'up and doing' to-morrow.' Nothing in fact discourages them. 'Go ahead!' they cry; and ever prepared to act, 'go ahead' it is. ${ }^{2}$

In fact, despite its earliest and strongest association with New England, this same spirit eventually became linked with the United States generally. "Go Ahead!' is our national motto," proclaimed Ballou's Monthly Magazine in 1881. "We Americans are always striving to obtain and never waiting to enjoy." When used as an adjective, the phrase was said to be "distinctively American." Purportedly, this people "by virtue of their restless, untiring activity and the facility with which

${ }_{1}^{1}$ American Magazine of Useful and Entertaining Knowledge, Vol. 1 (Boston: Sibley and Ticknor, 1836), 1.

2 Van Wyck Brooks, The Flowering of New England, 1815-1865, Rev. Ed. (E. P. Dutton and Co., 1940), 528; and American Magazine of Useful and Entertaining Knowledge, Vol. 3 (Boston: Sibley and Ticknor, 1837), 181. 
they adapt themselves to new surroundings and conditions, are said to be a goahead nation-a type of bold and fearless progress." Americans not only embraced the idea, but invented new words to encapsulate its essence: "goaheaditiveness" and "go-aheadifying." 3

If any place in the early American republic begged for inhabitants with "goaheaditiveness," it was the newly developing portion of the United States west of the Appalachian Mountains. Actually, patriots passed an ordinance organizing the Territory Northwest of the Ohio [River] in 1787, two years before they inked the national Constitution. This region eventually became five states, with Ohio taking the lead in 1803. National expansion had been made possible partly because the seaboard states of the new nation agreed to relinquish their western claims. However, shortly later expansion received even more impetus when President Thomas Jefferson approved the Louisiana Purchase in 1803, adding a north-south swath comprising a third of the present continental United States. With boundaries growing at a remarkable rate, the new western territories-once officially organized for settlement-beckoned the onrush of can-do migrants that quickly poured into them. In fact, so associated with boundless opportunity was the "great Republic of the West" that some observers claimed people in those locales fairly "breathe[d] a go-ahead atmosphere." The heady air of potential success was so thick, wrote one, that it even "'tastes good in the nostrils."'4

New Englanders had been migrating inland for generations, first to the frontier western portions of their own colonies, and later into what became Vermont and then into upstate New York. The closest areas to fill up from this rush soon became mere wayside stops for hordes more, edging westward by degrees.

\footnotetext{
${ }^{3}$ Ballou's Monthly Magazine, Vol. 13 (Boston: 1861), 491; Americanisms, Old and New, John S. Farmer, Ed. (London: Poulter and Sons, 1889), 2267; and Knowledge: An Illustrated Magazine of Science, Literature and Art, Vol. 10, Richard Proctor, Ed. (Richard Proctor, 1886-1887), 276.
} 
To many, it seemed the whole population of the Atlantic seaboard states was stretching farther and farther inland as lands opened for settlement.

Their most common migration path predated and predicted that of the Erie Canal, the completion of which in 1825 convinced ever larger numbers that the time was ripe for a western venture. At the canal's terminus in Buffalo, they wended their way along the southern boundaries of the Great Lakes, dispersing themselves gradually inward. Actually, most went westward by fits and starts, meandering ever farther from home until they finally settled on a promising situation. They began their journeys during all stages of life, as newborns-in-arms to aging men, although the majority migrated during young adulthood or middle age. Those who were young and single often traveled alone. Men with families might venture ahead first to find a suitable location before sending back for loved ones, whose participation in these undertakings helped determine their final shape. Migrating New Englanders often traveled in kinship groups, and occasionally whole towns sent a large cohort en masse. But come they did, in a great torrent hastening so mightily out of New England that it led inhabitants there to remark in wonder on their outgoing tide of population. ${ }^{5}$

Early national leaders often linked America's potential for future progress and happiness to geographical expansion. Indeed, to many Americans the emerging West represented the most obvious place to test post-Revolutionary possibilities for self-making. Land was cheap and plentiful, communities awaited building, and leadership roles awaited filling. To many, newly opened territories

5The two standard early works on Yankee migration are Stewart H. Holbrook, The Yankee Exodus: An Account of migration from New England (New York: Macmillan, 1950) and Richard Lyle Power, Planting Corn Belt Culture: The Impress of the Upland Southerner and Yankee in the Old Northwest (Indianapolis: Indiana Historical Society, 1953). Community studies offer some insight into localized pockets of relocated Yankees. Two examples include Susan E. Gray, The Yankee West: Community Life on the Michigan Frontier (Chapel Hill: University of North Caroline Press, 1996), and Mary P. Ryan, Cradle of the Middle Class: The Family in Oneida County, New York, 1790-1865 (Cambridge: Cambridge University Press, 1981). On the effects of depopulation on rural New England communities, consult Hal S. Barron, Those Who Stayed Behind: Rural Society in Nineteenth-Century New England (Cambridge: Cambridge University Press, 1984). 
appeared the best place to pursue the economic, political, and legal independence that signaled full male adulthood and respectability. Even without fully grasping the significance of changes underway around them, Americans witnessed the effects of demographic and territorial growth, political revolution, religious revivalism, and nascent industrial capitalism. Commercial markets expanded rapidly alongside the improvements in legal, financial, and transportation structures necessary to attract investors. In a world that for many appeared teeming with possibilities, postRevolutionary Americans drew little distinction between the exercise of political liberties and pursuit of the main chance. ${ }^{6}$

Individual migrants carried a variety of personal ideas about changes linked to the Revolution with implications for politics, economy, and society. For example, some welcomed escape from a home region too orthodox for their own religious tastes, having only recently shed the mantle of established religion. Others desired independence from entrenched local gentility unwilling to share the reins of influence, despite the implications of democracy. Virtually all were alert to the potential connection of personal independence to affordable land, and most appreciated the importance for expanded commerce of navigable Western waterways and roads. Men with access to capital or investors imagined that in a short time rising land values, local development, and settlers' needs for basic goods would yield remarkable returns to those ambitious enough to act promptlyand on as large a scale as possible.

This study is about white male Easterners who responded to the West's call for go-ahead men. All with ancestral ties to New England, they exemplified that 'up

6 On transformations underway in America and their implications for social change, see Christopher M. Clark, Social Change in America (Chicago: Ivan R. Dee, 2006); Charles Sellers, The Market Revolution in America: Jacksonian America, 1815-1846 (New York: Oxford University Press, 1991); Gordon S. Wood, The Radicalism of the American Revolution (New York: Vintage Books, 1991) and Empire of Liberty: A History of the Early Republic, 1789-1815 (New York: Oxford University Press, 2009); Daniel Walker-Howe, What Hath God Wrought: The Transformation of America, 1815-1848 (New York: Oxford University Press, 2007); and Joyce Appleby, Inheriting the Revolution: The First Generation of Americans (Cambridge, Massachusetts: Belknap Press, 2000). 
and doing' Yankee spirit of which Hawthorne wrote. Striving upward and alert to opportunity, the fathers, brothers, and husbands who dominated these migrating ranks truly were go-ahead men. However, we should not view their departures from Eastern homes and families as inevitable or solely the product of individual choice. Toward the end of the eighteenth century, traditional social and commercial relationships based on patronage and hierarchy began to give way before a culture that increasingly championed self-mastery, free enterprise, and individual exertion. Alongside this growing celebration of personal ambition, market expansion, urbanization, and the beginnings of industrialism disrupted production patterns that previously had tied household members closely to home. Concurrent with these changes, high land prices, overly divided estates, and overtaxed soils in the Eastern seaboard states challenged families hoping to provide livelihoods for sons eager to leave home-a traditional expectation among New Englanders. ${ }^{7}$

Colonial New England fathers had normally launched sons into viable careers. Most often, this assistance was tied closely to the distribution of family lands. However, it also sometimes took the form of arranging apprenticeships, offering money for entrepreneurial endeavors, or funding college educations. Fathers also offered non- material aid in the form of professional contacts or advice. Of course families differed in their abilities to fulfill traditional expectations, and within families not every son received the same provision for his future career. In addition, some expected sons to repay family coffers from career earnings. If a young man's father was unable to underwrite his launch, sometimes sympathetic uncles or brothers filled the breach. ${ }^{8}$

Economic changes of the late-eighteenth and early-nineteenth centuries rendered a son's expectation of career provision less likely to materialize even as

\footnotetext{
${ }_{7}$ Lisa Wilson examines this cultural expectation in some detail in Ye Heart of a Man: The Domestic Life of Men in Colonial New England (New Haven: Yale University Press, 1999), Chapter One.

8 Ibid.
} 
Americans began to embrace the concept of the self-made man and identified the emerging West as a locus of special opportunity. Indeed, in the half-century after the Revolution, ambitious striving and the pursuit of distinction or honors became linked to national patriotism and public spirit, codifying desires that once had signaled excessive selfishness and pride. Young men faced increased pressure to distinguish themselves even as many fathers became less able to provide the foundations necessary to achieve it. Complicating their lives further was the cultural expectation that success-and unfortunately, failure-depended less on extenuating circumstances than it did on a man's good habits and character, or lack thereof.' Early adulthood became a time marked by high hopes, yet fraught with equally high anxiety about how to achieve them. Consequently, ambitious young men in the early republic often found themselves casting about for male relationships that could help them weather the uncertain seas threatening to overtake many of them. Those men-friends, kin, mentors, and professional or organizational compatriots, for example-often provided or supplemented the kinds aid that New England fathers had offered more reliably in the past. Aspiring men fashioned their own networks of support, within which they worked out not only their particular career paths, but their ideas about life, and about themselves.

This study offers a fresh examination of ambitious nineteenth-century Northern men by delving deeply into some of those close male relationships through which many negotiated the tensions between cultural expectations and personal reality. Its focus is the emerging West of the early republic, a setting where expectations of success were extremely high, and where Yankee "goaheaditiveness" was thought to achieve its purest expression. Although some scholars have linked Northern middling men to a growing nineteenth-century cult of ambition or self-making, their works are delineated by region, chronology, or

'On the rise of an early national cult of personal ambition see J. M. Opal, Beyond the Farm: National Ambitions in Rural New England (Philadelphia: University of Pennsylvania Press, 2008). Scott A. Sandage, Born Losers: a History of Failure in America (Cambridge: Harvard University Press, 2005), addresses the common belief that success-and failure-were "in the man." 
emphasis in ways that place the ambitious Yankee frontiersman outside their purview. Several describe the rise of a distinctly Northern, middle-class manhood, but they have not isolated how the relationships that undergirded it functioned for individual men propelled almost without explanation on an ambitious westerly course toward imagined opportunities..$^{10}$ This project pulls the focus away from an overemphasis on Eastern towns or urban centers and examines instead those men who were willing - in some cases almost driven — to forgo proximity to Eastern amenities and family to pursue their particular vision of the successful life. Moreover, it challenges a prevailing view that a cultural celebration of individualism reflecting broad social changes underway was exemplified by hordes of ambitious, competitive young men eager to try their hands at self-fashioning. In one sense they were, but if the research for this study is indicative, often a circle of close male associates surrounded and protected aspiring men from suffering the full potential brunt of the competitive marketplace.

"Go-Ahead Men" is based upon a close social reading of a cohort composed of Northern men of Yankee origin or ancestry who pursued opportunity in a developing environment-in this case, the trans-Appalachian West and beyond. It isolates how man-to man relationships among male relatives, mentors, friends, and other male associates-not always fellow Yankees-informed this process. As the assumption that family patriarchs would launch adult sons faded, tensions emerged regarding exactly how young men would achieve their imagined

10 Anthony Rotundo, American Manhood: Transformations in Masculinity from the Revolution to the Modern Era (New York: Basic Books, 1993); Michael Kimmel, Manhood in America: A Cultural History (Jew York: Free Press, 1996); Stuart Blumin, The Emergence of the Middle Class: Social Experience in the American City,1760-1900 (Cambridge University Press, 1996); Thomas Augst, The Clerk's Tale: Young Men and Moral Life in Nineteenth-Century America (Chicago: University of Chicago Press, 2003); Brian P. Luskey, "Jumping Counters in White Collars: Manliness, Respectability, and Work in the Antebellum City," Journal of the Early Republic 26 (Summer 2006): 173-219; J. A. Mangan and James Walvin, eds., Manliness and Morality: MiddleClass Masculinity in Britain and America 1800-1940 (Manchester: Manchester University Press, 1987); David D. Gilmore, Manhood in the Making: Cultural Concepts of Masculinity (New Haven: Yale University Press, 1990); Bertram Wyatt-Brown, Southern Honor: Ethics and Behavior in the Old South (Oxford: Oxford University Press, 1982) identifies a distinctive Southern masculinity centered on manly honor; and Nicole Etcheson, "Manliness and the Political Culture of the Old Northwest, 1790-1860," Journal of the Early Republic 15 (Spring 1995): 59-77, asserts an identifiable regional masculinity in the frontier upland South. 
station in life, especially in an era of high expectations. Strategies emerged for dealing with the potentially atomizing and isolating effects of a burgeoning capitalist and market economy. As the nineteenth century progressed, some men found that they involved ever more distant or complex networks of masculine support. This study investigates periods in men's lives when special challenges to maintaining close masculine bonds tested those ties, as well as how the men under examination reacted to the disappointment of broken trust, when it occurred. Without doubt, some men in the early republic developed a personal culture of cooperation to successfully confront a world that celebrated competition. What were their circumstances? What relationships functioned this way, how were they understood over time, and did they weather the strain of conflict or disruption?

The always present fear in aspiring men's lives was that they would somehow lose social ground-that material gains or reputations would disappear. This anxiety was not a trifle. Nineteenth-century Americans on the frontier and off were quite often keenly aware-some might say preoccupied-regarding perceived differences in status. Even Walt Whitman, herald of the "builders and steerers of ships and the wielders of axes and mauls, and the drivers of horses," wrote in 1858 that "the most valuable class in any community" was the "middle class, the men of moderate means." ${ }^{11}$ By then, even casual observers connected mode of employment or income level with rank. The men in this study did not reject those associations, but they were often less concerned with general social arrangements than they were with proving themselves capable of success. In other words, their go-aheaditiveness also revealed itself in staying productive, gaining respect for doing so, and in not failing.

11 Walt Whitman, I Sit and Look Out: Editorials from the Brooklyn Daily Times, by Walt Whitman, selected and edited by Emory Holloway and Vernolian Schwartz (New York: 1932), 145. The standard work on the development of a middle class, albeit in the urban North, is Blumin, The Emergence of the Middle Class. 
Max Weber linked this perpetual anxiety about non- or under-productivity to the work model of the New England Puritans in The Protestant Ethic and the Spirit of Capitalism over one hundred years ago. However, scholars are even now confirming the truth of the enormous pressures bearing on nineteenth-century men who feared failure to go ahead. Indeed, Scott Sandage shows in his recent work, Born Losers, just how universal had become the cult of ambition, and how devastating to aspiring men was the experience of failure. Even more recently, Brian Luskey revealed the precarious nature of the clerk's life in nineteenth-century America, wherein social aspirations often conflicted with life's realities for those near the bottom professional rung of the capitalistic marketplace. ${ }^{12}$ The responsibility to make something of themselves weighed heavily on men in the early republic, and they wore this burden very self-consciously more often than not. Distinction, respectability, public usefulness - this was the vocabulary the men in this study used to describe their aspirations. It went without saying that men achieving these things usually also attained comfortable levels of existence. However, without denying they may have owned some genuine motives for the public good, these words were also code for being acknowledged by society, especially by leading men, as worthy of their approval, indeed capable of joining their ranks.

The methodology of this project is mostly descriptive and tied to sources chosen because they are especially candid and revealing-mainly the personal letters of men whose names are not recognizable to most people. As self-

\footnotetext{
12 Max Weber, The Protestant Ethic and the Spirit of Capitalism, (New York: Scribner and Sons, 1958); Sandage, Born Losers; Brian P. Luskey, On the Make: Clerks and the Quest for Capital in Nineteenth-Century America (New York: New York University Press, 2010), and Daniel Walker Howe, Making of the American Self: Jonathan Edwards to Abraham Lincoln (Oxford: Oxford University Press, 2009). On failure's potential to threaten perceptions of manhood, see Toby L. Ditz, "Shipwrecked: or, Masculinity Imperiled: Mercantile Representations of Failure and the Gendered Self in Eighteenth-Century Philadelphia, The Journal of American History (1994) 81 (1): 51-80. Ditz identifies the tensions that confronted the wealthiest of Philadelphia's merchants as relationships formerly based upon commercial patronage and reciprocity sometimes changed into what he calls "mercantile friendships."
} 
representations, these sources are of course subject to a certain amount of imaginary construction on the part of the authors. However, they are unparalleled as windows into close male relationships and how they functioned, especially when both sides of an exchange are available. Without entirely rejecting the prescriptive literature that abounded in middle-class circles and which many scholars find useful, this project nonetheless relegates them, along with the implications of popular literature or other cultural productions of the Eastern elite, to supporting roles.

All manner of sources agree that the self-conscious desire to establish oneself was quite characteristic of the developing middle class in the nineteenth century. Unfortunately, men who may have attempted an ascent instead from the very lowest strata of society rarely left documents to trace their motivations for migrating, or the results. Certainly, men migrated from the East, even from relatively homogeneous New England, who did not identify themselves or their ancestors as New England Yankees. Moreover, the cohort here under studythose who did claim Yankee backgrounds-recognized a commonality with other men as men. More specifically, the ambitious Eastern men lured West by potential opportunity recognized that they chased dreams of success alongside men with a variety of backgrounds. According to Dana Nelson, white men in the early American republic navigated the challenges of "competitive individualism and market exchangeability" by identifying as a common fraternity, in marked distinction to "women, racial others, and national 'foreigners." While this may be generally true for the men examined for this study, the degree to which they took white manhood as the "natural" model for the new republic varied from man to man. ${ }^{13}$

${ }_{13}$ Dana D. Nelson, National Manhood: Capitalist Citizenship and the Imagined Fraternity of White Men (Durham, North Caroline: Duke University Press, 1998), 37. 
What these men invariably agreed upon was what they wanted from their westward migration. In a classic 1953 study, Planting Corn Belt Culture, Richard Lyle Power writes, "The simplest way to classify the Yankee's motives is to say that they were religious, economic, and political, though these were never quite separable from one another." Lyle misses the difference between primary motive and the possible secondary cultural effects of relocation. Granted, there were religious emigration companies who sent population westward and New Englanders founded innumerable social and religious organizations to help shape the society forming there. However, by overemphasizing corporate migrations or organizational influences scholars risk not hearing the collective voice of individuals who migrated. The men in this study by and large make it plain: their primary and overriding concern was that they make something of themselves, through what means and with whose help might be available to them. ${ }^{14}$ Those who achieved "respectable" status were generally men whose families had been at least middling in socio-cultural outlook, but whose ability to maintain that status or pass it on to sons was severely diminished. Often, the cohort examined for this study set out deliberately to achieve regional prominence and shape the public discourse-to influence the conditions under which many less well-connected people lived. Understanding the process by which they strove for that status, leveraging beneficial masculine connections along the way, may reveal not only why they pursued such a course, but infer why others could not, or did not even try.

The three central chapters of "Go-Ahead' Men" examine specific case studies of Northern men. The first-and earliest-reveals the compromises a developing market economy demanded of Northwest Territory Judge John Cleves Symmes's idealization of the family patriarch and gentleman farmer, and how he negotiated that terrain as he proffered advice to financially distressed grandsons.

${ }^{14}$ Power, 37. 
Symmes was one of the earliest migrants to the Ohio River region after the organization of the Northwest Territory. He was a man of some substance already, but relocated after the Revolutionary War to the vicinity where Cincinnati later grew up, disappointed that other men in his home region in New Jersey had secured leadership status in his absence. Symmes had become acquainted with George Washington during the war, and the president's appointment of Symmes as a Northwest Territory judge fit perfectly with his plan to become a land magnate and rich speculator there.

Raised mostly on Long Island by grandparents, Symmes's ties to his New England birth region were somewhat ephemeral and rarely asserted overtly into the cosmopolitan world in which he aspired to identify. In fact, his imagination of himself as the genteel owner of a country estate remained stuck precisely therein his imagination. The reality of managing sales from his huge speculative land holdings never quite matched the life Symmes envisioned for himself, or those planned for the two grandsons whose futures became his burning concern when their mother died around 1800. This chapter examines the patriarchal role Symmes attempted to play in those boys' lives, albeit from across state lines, and how their own unreliable Kentucky planter father complicated Symmes's ability to rescue them from ruinous futures.

The second case study shows the substantial impact Congressman Joshua Giddings's professional mentor, Elisha Whittlesey, had on this noted abolitionist's rise and subsequent effort to find his own political voice, as well as how it complicated Giddings's relationships with other men. This chapter takes up around 1820, shortly after the Symmes study concludes. Where Symmes's migration to the Old Northwest took him to the Ohio River region, Giddings's father located his family, ten-year-old Joshua among them, along the southern banks of Lake Erie. There, on Ohio's Western Reserve, fabled then for being perhaps more like New England than New England had become, Giddings worked out a formula for 
cooperative male relationships that offset his inauspicious beginnings and demonstrated his capability to become a regional leader in civic, political, and religious life.

The specter of slavery-or more precisely, what to do about it-dogged Giddings's steps beginning in the 1830s, when the Reserve was rocked by an exploding antislavery movement and an equally volatile antiabolitionist backlash. From then forward, it colored all of Giddings's masculine relationships in some way, even contributing to the serious decline of some very close friendships. Moreover, it damaged the close fifteen-year relationship Giddings had shared with his mentor even as it made developing a similar one with his own young assistant nearly impossible.

The Giddings study is an extended one, carefully covering two decades of his progress in the anti-Jacksonian political realm that he, Whittlesey, and indeed most Reserve men inhabited. Safely ensconced therein, Giddings adroitly maneuvered his ascent, assisted in no small measure by his political ties to thenCongressman Whittlesey. Central to understanding Giddings's rise is realizing the importance he placed on the exercise of the civic voice among his Reserve neighbors, and the necessity of his understanding it before he could aspire to shape or represent it. This chapter is extended so that process can be examined in some detail, and also because it allows the narrative to incorporate Giddings's attempted transmission of Whittlesey's mentorship model to his own political assistant, once Giddings took Whittlesey's place in Congress.

The third study involves Oscar Learnard, a Vermont migrant to "Bleeding Kansas," pioneer hero, and state-builder. Learnard began life as the son of a struggling Vermont merchant whose involvement in civic affairs was probably the more successful part of his life. Making sure his only son received an adequate early education was a priority for Learnard's father, and it is in those academic 
settings where Oscar's considerable talents truly shined. There, he became an acknowledged leader among his peers, and there his ideas about masculine cooperation and competition formed. Traveling as much for adventure as for health concerns, Learnard sampled the South and the developing West, marking the latter as the place to make a real future for himself. He attended military academy with a friend's aid and then became a lawyer, but it was land—both for settlement and speculation-that drew him to Kansas Territory in the mid-1850s, just as the territorial civil war known as Bleeding Kansas was getting underway. Learnard landed in the "Yankee town" of Lawrence among men who were front-and-center to the display of breathtaking events. This study reveals that the code of masculine conduct Learnard applied there had formed earlier, certainly with input from his father, but mainly within a close circle of New England school chums. It also reveals that a sense of masculine commonality sufficient to mitigate the effects of competition-so elusive to always-struggling fellow New England migrant John Brown-served Learnard well and informed the vitriol he later directed at the hagiographic Brown mythology.

All three of these case studies focus on men who migrated, alone or with their families, to the developing western regions of the early Republic. In every case the move represented some man's dream to rise above circumstances in the Eastern locale of his home. Even for Giddings, who was ten when he arrived on the Reserve, homesteading westward had been part of his earliest awareness, and the bitter experiences of his father made him determined to discover how a man might make himself successful there. Learnard moved as a young man, traveling singly, although never landing far from a friendly Yankee by design. Symmes, the oldest of the three, navigated the challenge of enacting his patriarchal vision for grandsons from across the Ohio-Kentucky line, an activity which proved nearly as precarious as navigating the river that marked that divide had been during his frequent travels along it and its tributaries. These men carried their own ideas about what roles close male associates might play in the lives of 
young men hoping for a launch into adulthood, and during the hoped-for subsequent rise. What makes the three men similar is that they were of New England background, had ambition in boundless supply, and viewed the developing West as the place to unleash it. All weathered times of crisis that tested masculine bonds. As Hawthorne writes, "[A]lthough they may encounter reverses to-day, like 'true Yankees' they are 'up and doing' to-morrow." ${ }^{.15}$ They were all goahead men. 
CHAPTER 1: THE WISTFUL PATRIARCH: JOHN CLEVES SYMMES ANDHIS GRANDSONS

In the summer of 1803 , a nine-year-old Kentucky boy received his very own letter. The message began: "And pray my dear grandson Charles, was you not looking for birds eggs, while your brother John was writing a kind letter to grandpah." ${ }^{11}$ That single statement probably confirmed what young Charles already knew: older brother John sometimes tattled, their relatives enjoyed receiving mail from them, and-most important-the boys' grandfather, Judge John Cleves Symmes, was determined to be a force for good in their lives.

Charles Wilkins Short and his brother, the judge's namesake John Cleves, were nine and eleven, respectively, when the above letter arrived. Intensely affectionate to his family, Symmes had increased his interest in the boys' wellbeing when their mother-his elder daughter-died two years earlier and they were sent to live with a paternal aunt and her husband. Symmes longed "exceedingly" for extended visits from his grandsons, and his letters to them demonstrate the avid interest the judge took in fostering their development. ${ }^{2}$ They also reveal what Symmes believed were the appropriate manners,

${ }^{1}$ Symmes to Charles Short, 2 June 1803, The Intimate Letters of John Cleves Symmes and His Family, ed. Beverley W. Bond Jr. (Cincinnati: Historical and Philosophical Society of Ohio, 1956), 1.

${ }^{2}$ Symmes to John Cleves Short, Peyton Short, and Charles Short, 1805 (date uncertain), Bond, Intimate Letters, 20. Peyton Short, young son of Symmes's deceased brother Timothy, spent a good deal of time with the Short family. Symmes oversaw the well-being of his only sibling's large family, who lived nearby. Timothy and his family had followed Symmes to the Miami Purchase. Bond, Intimate Letters, xxvii, xix-xxiii. Stephen M Frank cautions that a "wide range of parental behavior and beliefs" characterized the nineteenth-century Northern fathers he studied. Given Symmes's movement from New England to the middle Atlantic coastal region, the salient cultural referents from which he drew to inform his own fatherhood, or more importantly, his grandfatherhood, remain unclear. Moreover, no work on grandfatherhood as a separate condition appears to exist, and to assume a man's fathering and grandfathering styles matched would be making a leap not justified in the literature. See Frank, Life With Father: Parenthood and Masculinity in the Nineteenth Century (Baltimore: Johns Hopkins University Press, 1998), 2. Lisa Wilson claims that New England families were very affectionate, a point that scholars sometimes miss because of the language colonists used. See Wilson's Ye Heart of a Man: The Domestic Life of Men in Colonial New England (New Haven: Yale University Press, 1999), Chapter Five. 
education, and vocations for young men confronting life in the post-Revolutionary America of the emerging West. The realities of financial uncertainty forced Symmes to alter his idealization of the gentleman landowner, resulting in a model for manly competence containing the awkward pairing of paradoxical messages. Symmes's man for the age was scholarly, gentle, frugal, solicitous, completely family-oriented and entirely non-combative. The judge recognized, however, that the fluid economy of a rapidly-developing frontier sometimes required that he also be calculating, suspicious, and determined to win the competition of the professional marketplace.

The death of the boys' mother, Maria, had temporarily disrupted their home. $^{3}$ Consequently, Symmes urgently desired to impart as much encouragement and genuinely useful guidance as possible to these two cherished grandsons. This study examines Symmes's attempt to help shape and later launch his grandsons during the problematic decade that followed. It also touches on how Symmes felt about the roles played by other men in their extended families as they promoted —or obstructed—Symmes's vision. This work provides a window into the strategies by which some men structured their lives in the early republic, most notably the way the differing perceptions held by Symmes and the boys' father of their roles as family patriarchs complicated Symmes's relationship with his grandsons.

The mid-eighteenth-century New England culture into which Symmes was born dictated that fathers provide a source of livelihood for sons approaching adulthood. Occasionally, older brothers or other close kin assisted or supplanted the efforts of fathers unable to launch sons entirely themselves. Traditionally, aid from family patriarchs had come as a gift or inheritance of land, but could also

\footnotetext{
${ }^{3}$ Bond, Intimate Letters, xix. A summary of the lives of the Symmes family members appears in the introduction to that work. Also see The Correspondence of John Cleves Symmes: Founder of the Miami Purchase, ed. Beverley W. Bond, Jr. (New York: MacMillan Company, 1926); and American National Biography, Vol.21, ed. John A. Garraty and Mark C. Carnes (New York: Oxford University Press, 1999), 230-232.
} 
include money, professional contacts, college education, or guidance. Families tended to decide what path each son would follow, and sometimes expected that sons successfully launched into careers would repay the family coffer from their earnings. ${ }^{4}$

Symmes spent most of his youth on Long Island in the care of his maternal grandparents, but he understood traditional New England patriarchal roles. In fact, much later he reminded a grown daughter that because he had consciously departed from the patriarchal pattern of withholding gifts of family land until no longer needed, he expected her particular appreciation. It remains uncertain exactly who aided Symmes's attainment of status and wealth in the East, but he apparently married well, especially for a boy whose clergyman father had become an itinerant missionary after he lost his settled church. In any case, by the time Symmes had grandsons to advise, he was a notable from New Jersey who identified with the national elite and imagined his patriarchal role involved guiding them gently into lives of wealth and ease, engaging with the professional or commercial marketplace as part of the gentleman's well-rounded activities, not a survival strategy.

A young adult at the beginning of the Revolutionary era, Symmes's transformation to regional legal and political leader occurred alongside the momentous social changes unleashed as Americans rejected status as British colonial subjects. His speculative venture in the Old Northwest only mirrored a near-consensus that the post-Revolutionary expansion of markets and territory offered incomparable benefits to any man willing to pursue them. Indeed, to the

4 Wilson, Chapter One. 
minds of many the Revolution merely confirmed that general social benefits resulted when masses of responsible citizens pursued their self-interest. ${ }^{5}$

Symmes had been a colonel of his local New Jersey militia during the Revolutionary War. He was also a member of the New Jersey legislature, a drafter of its constitution, and an associate judge on the New Jersey Supreme Court. He won election to the Continental Congress in 1785. His father had been a Harvard-educated Massachusetts man, a minister turned itinerant missionary during the Great Awakening. Symmes was born on Long Island and reared there by maternal grandparents. Symmes was not college educated himself, about which he always felt a little defensive. Nonetheless, he received training in surveying, law, and the classics, and achieved beneficial social connections through three well-placed marriages. ${ }^{6}$

Struck with western fever like so many after the Revolution, including Washington and Jefferson, Symmes petitioned Congress in 1786 to purchase two million acres in the Northwest Territory. His tract in what is now southwestern Ohio was sometimes called the Miami Purchase because it was bounded by the Great and Little Miami Rivers. By 1788, Symmes was a recently-appointed territorial judge and shortly later led a party of early settlers to his reserved lands. ${ }^{7}$ He divided his time over the next decade among traveling the legal circuit, erecting his house and farm buildings, and colonizing his extensive property.

John Cleves Symmes may seem an odd choice for a study regarding masculine relationships, for historians have always demonstrated a certain

\footnotetext{
5 On changes brought about by the Revolution, see Gordon Wood, The Radicalism of the American Revolution (New York: Vintage Books, 1993); and Empire of Liberty: A History of the Early Republic, 1789-1815 (New York: Oxford University Press, 2009).

${ }^{6}$ Symmes made three beneficial matches, through which he garnered "many influential connections." Bond, Intimate Letters, xvi-xvii, xxiii.
}

${ }^{7}$ American National Biography, 230-232. 
ambivalence regarding the frontier judge. Douglas Hurt claims the "unconcerned" Symmes stands out among Ohio Country land developers for his willingness to play "fast and loose." Symmes also tended toward greed and negligence, according to Andrew Cayton. Timothy Shannon offers a slight rehabilitation, contending that Symmes's problems were not entirely his fault, given the challenges of large-scale speculation in territorial Ohio. The kindest assessments come from Beverley Bond, the editor of the Symmes papers and author of The Civilization of the Old Northwest. In that 1934 publication, Bond asserts that Symmes, despite his "peculiarities," was a "farsighted pioneer who was somewhat careless in details, but was not intentionally dishonest." Contradictions regarding the judge's character abound: scholars describe him as quarrelsome, careless, and avaricious, but also as meticulous, generous, good-natured, and wise. $^{8}$

On the other hand, Symmes offers the potentially fertile example of his complex life, characterized by the bipolar tensions of plenty and penury, status and embarrassment, love and loss. An expansive range of emotional experiences comes through clearly and frankly in his correspondence. Of elevated rank and an important figure on the frontier of the early republic, Symmes nonetheless lost all his substantial holdings in legal settlements and was eventually reduced to writing his nephew to borrow a dollar to buy peaches. ${ }^{9}$ Symmes made his conclusions regarding the best path to success as a man

\footnotetext{
${ }^{8}$ R. Douglas Hurt, "John Cleves Symmes and the Miami Purchase," in Builders of Ohio, ed. Warren Van Tine and Michael Pierce (Columbus: Ohio State University Press, 2003), 24; Beverley W. Bond, Jr., The Civilization of the Old Northwest: A Study of Political, Social, and Economic Development, 1788-1812 (New York: MacMillan Company, 1934), 85; Andrew R. L. Cayton, The Frontier Republic: Ideology and Politics in the Ohio Country, 1780-1825 (Kent, Ohio: Kent State University Press, 1986), 61; and Timothy J. Shannon, " 'This Unpleasant Business': The Transformation of Land Speculation in the Ohio Country, 1787-1820," in The Pursuit of Public Power: Political Culture in Ohio-1787-1861, ed. Jeffrey P. Brown and Andrew R. L. Cayton (Kent, Ohio: Kent State University Press, 1994); ;and Fred J. Milligan, Ohio's Founding Fathers (Lincoln: iUniverse, 2003), 94-98. One thing upon which many scholars agree is the national significance of the history of the Ohio region during its territorial and early statehood periods. See Daniel Feller, "Oh Why, Oh Why Ohio?, Reviews in American History, vol. 17, no. 2 (June 1989), 205-209.
}

${ }^{9}$ Symmes to Daniel Symmes, 1809-1811 (date uncertain), Bond, Intimate Letters, 136. 
disillusioned by his own experience and with eyes finally open to the inadequacy of social connections in overcoming the insistent incursions of a market economy. With no sons of his own, Symmes's fondest wish was to help set up his grandsons as landed gentlemen. This tender, protective facet of his personality has gone largely ignored due to the understandable emphasis scholars place on his important role as Ohio Country jurist and founder. ${ }^{10}$

The nineteenth century dawned with little hint of the calamities that were about to befall John Cleves Symmes, who had served by then for over ten years as one of three federally-appointed territorial judges of the Old Northwest. ${ }^{11}$ Sonin-law William Henry Harrison, elected in 1799 as that territory's non-voting delegate to Congress, was optimistic that Symmes's rather creative interpretation of his federal contract to purchase extensive holdings there would garner a sympathetic hearing from that body. ${ }^{12}$ In 1800 , Harrison secured passage of a federal land act setting reasonable prices on public lands in the Northwest Territory, temporarily forestalling Symmes's continual fears that Congress would undercut what he charged for acreage in his own tract. About the same time, Symmes's ambitious son-in-law also benefitted from the passage of a bill in Congress creating the Indiana Territory, where he was appointed territorial governor. ${ }^{13}$

${ }_{10}$ Andrew Cayton briefly discusses Symmes's nurturing relationship with his young, motherless grandsons in Frontier Indiana (Bloomington: Indiana University Press, 1998), 193-194.

${ }^{11}$ Information relating to the territorial system of government in the Northwest Territory and Symmes's part in it is found in David K. Watson, "The Early Judiciary, Early Laws and Bar of Ohio," Ohio History 3, (1897): 141160; William L. Jenks, "Territorial Legislation by Governor and Judges," The Mississippi Valley Historical Review 5, No. 1 (June 1918): 36-50; Bond, The Civilization of the Old Northwest, and R. Douglas Hurt, The Ohio Frontier: Crucible of the Old Northwest, 1720-1830 (Bloomington: Indiana University Press, 1996. Also see, George W. Knepper, Ohio and its People (Kent, Ohio: Kent State University Press, 1989), which covers this topic and is a competent overall history of Ohio.

${ }^{12}$ Bond, Correspondence, 19. For Harrison's early career in territorial governance, see Robert M. Owens, Mr. Jeffersons Hammer: William Henry Harrison and American Indian Policy (Norman, Oklahoma: Oklahoma University Press, 2007); Jenks, 44-45; and also Bond, Civilization of the Old Northwest. The younger of Symmes's two daughters, Anna, married Harrison in 1795.

${ }^{13}$ The Pursuit of Public Power: Political Culture in Ohio-1787-1861, ed. Jeffrey P. Brown and Andrew R. L. Cayton (Kent, Ohio: Kent State University Press, 1994), xv; Bond, Civilization of the Old Northwest, 151; and 
Symmes's fortunes were changing, however. The loss of his son-in-law's presence in Congress left Symmes with fewer connections to those with whom he had to negotiate any changes to his rights and obligations regarding the Miami Purchase. Unfortunately, the Harrison Land Act also offered Ohio Country settlers easy purchase arrangements through regional land offices, potentially siphoning buyers from private developers such as Judge Symmes. ${ }^{14}$

The presidential election of 1800 presented Symmes some measure of optimism concerning his situation. As the contest resolved early in 1801 in Thomas Jefferson's favor, doubtless Symmes could also foresee the diminishing national influence of territorial governor Arthur St. Clair, super-Federalist, judicial antagonist, and determined obstacle to the judge's haphazard approach to land sales. ${ }^{15}$ Savoring his enemy's certain decline in his ability to trouble Symmes was not long on Symmes's mind, however, for soon he was already experiencing the first in a series of distressing personal setbacks.

\section{"Beloved Mah" and "Honored Pah"}

Early that same year, the boys' mother and Symmes's beloved elder daughter died. Maria Symmes Short was only 38 years old. Her death was not entirely unexpected, at least in Symmes's mind. Maria's health always had been frail, but especially so in the several months previous, during which she had also delivered her third child, daughter Anna. Symmes was especially close to his elder daughter. Commenting on one occasion regarding Maria's recurrent bouts

Knepper, 89. Located along the Ohio River in the Cincinnati region, Symmes's purchase was also bounded east and west by the Great and Little Miami Rivers.

${ }^{14}$ Shannon, in Pursuit of Public Power, 26-27; and Bond, Correspondence, 19.

${ }^{15}$ The staunchly formulaic St. Clair became Judge Symmes's nemesis due to the ad hoc nature of the latter's land claims and legal decisions. A wounded Symmes maintained that, in the matter of his land disputes, the governor treated him as if he were a British insurgent, attempting to establish a foreign claim to American soil. See Bond, Correspondence, 146-47. 
of poor health, Symmes wrote that he was "extremely afflicted" at the news, and would fly to her on "eagles wings, were it in my power." Actually, Symmes had been convinced for some time that both his daughters lacked the robustness necessary to carry them into old age. He had always hoped they and their families would eventually locate near him in the Cincinnati region, and encouraged their husbands to buy land nearby, which they did. It was probably some comfort that he was closely connected to the children of his deceased only brother, and they lived nearby. However, Symmes consistently mourned that so much distance separated him from his two daughters and their families. ${ }^{16}$

The boys' parents had been married eleven years. Father Peyton Short was the scion of an influential Virginia family. After receiving the usual fine education of Virginia planters' sons, Peyton Short struck out to explore investment possibilities in the newly-opened lands west of Virginia, including the "Cumberland Country" of present-day Tennessee and Virginia's district of Kentucky. It was on a 1788 trip through the latter that Short met Maria Symmes, then a guest in the Kentucky home of General James Wilkinson. ${ }^{17}$

Wilkinson had been a high-ranking Revolutionary War officer from Maryland and, like Symmes, was also an acquaintance of George Washington. Relocating to Lexington after the war, Wilkinson appeared in every way the wealthy gentleman, conspicuous among a local elite already distinguished for their "charm, hospitality, and 'conscious superiority'." Aspiring young men

\footnotetext{
${ }^{16}$ Bond, Intimate Letters, xviii-xix. Symmes to Peyton Short, 22 April 1798 and 17 March 1800, Bond, Correspondence, 54 and 58. Anna Symmes Harrison actually lived a very long life, preceded in death by her husband and all but one of her ten children, only two of whom lived to maturity. Migration of families to one region, whether at once or in stages, is one frequent characteristic of the major westward migration streams in United States history.

${ }^{17}$ Ann Biddle Wilkinson and Thomas Robson Hay, Letters of Mrs. Ann Biddle Wilkinson from Kentucky, 17881789 (Kessinger, 2006), 36; and Thomas Speed, The Political Club, Danville, Kentucky, 1786-1790 (Louisville: Filson Club Publications, 1894), 78. The fullest examination of the Short family and their various associates is C. W. Short and Mary Churchill Richardson, "A Chronological Record of the families of Charles Wilkins Short and Mary Henry Churchill," unpublished manuscript, Short Family Papers, Filson Historical Society.
} 
admired the dashing officer's self-assertive eloquence and suave manners. Consistent with tendencies present among the Southern gentry, Wilkinson was actually more adept at charming creditors and moneyed acquaintances than earning enough to support his luxurious lifestyle. He entertained lavishly, which no doubt impressed his guest Maria Symmes and her father, if Symmes was with her. It was there that Short, a suave Virginian with the most impressive conversational skills and manners, first caught Maria's eye. ${ }^{18}$

Maria's father also would have been impressed with Short's social graces, but probably more so with his pedigree. Peyton's father was a well-known Virginia planter and his mother was the daughter of a Cavalier British nobleman. Of more probable immediate interest, however, was Peyton's slightly older only brother and prominent American diplomat to Europe. William Short was enmeshed in the highest circles of power in the western world at this time, having begun as Thomas Jefferson's protégé, now referred to by Jefferson as his "adoptive son." Several years earlier, the two Short brothers had received an inheritance from their father, which Peyton was busy investing and managing—or mismanaging, but Symmes could not know that yet. ${ }^{19}$

So in the late 1780 s, perhaps Symmes saw no compelling reason to oppose openly Maria's proposed match to Short. Symmes had been thoroughly engrossed in his own efforts to gather an initial group of New Jersey migrants to settle with him in his vast Ohio Country landholdings. He may have heard some of the rumors of dishonesty, incompetence, and insubordination that followed

${ }^{18}$ Lowell H. Harrison and James C. Klotter, A New History of Kentucky (Lexington: University Press of Kentucky, 1997), 59-60; and Owens, 17. On the reputation of Lexington among larger towns in the emerging West, see Richard C. Wade, The Urban Frontier: Pioneer Life in Early Pittsburgh, Cincinnati, Lexington, Louisville, and St. Louis (Chicago: University of Chicago Press, 1959). The quote about the Lexington upper class is on page 107.

${ }^{19}$ The most complete information on William Short is available in George Green Shackelford, Jefferson's Adoptive son: The Life of William Short, 1759-1848 (Lexington, Kentucky: University Press of Kentucky, 1993). Also see C. W. Short and Mary Churchill Richardson, "A Chronological Record of the families of Charles Wilkins Short and Mary Henry Churchill," unpublished manuscript, Short Family Papers, Filson Historical Society. 
Wilkinson after the war. Even if those mattered to him, Symmes may not have realized how deeply involved Short was with Wilkinson and his circle of associates, which, after all, also included George Scott, a Brigadier-General in the Revolution. Besides, Symmes quickly became preoccupied with staving off Indian resistance to national expansion into the Northwest Territory. Indeed, before long his Miami Purchase lands bore the nickname "Miami slaughter house."20

Wilkinson and Short belonged to a group of prominent "anti-Virginia" Kentuckians then promoting the district's independent interests in opposition to Virginia's control-especially the necessity to acquire navigation rights on the Spanish-controlled Mississippi River. Both participated in a self-styled "political club" that debated issues important to Kentucky's future, where Wilkinson made "inflammatory and eloquent speeches" regarding Mississippi navigation. Most of Kentucky was not like Lexington and a few other growing western cities, "pockets of civility in a sea of insecurity," and men scrambled to gain some advantage in the "sordid mess" that 1780 s Kentucky represented. Moreover, no foregone conclusion existed among Kentuckians that future independence from Virginia necessarily aligned them with the new United States. In 1787 Short and Wilkinson were "deputed" to visit Congress on "business of a public nature," no

\footnotetext{
${ }^{20}$ On Short's involvement with Wilkinson and Scott, see Andro Linklater, The Artist in Treason: the Extraordinary Double Life of General James Wilkinson, Commander in Chief of the United States Army and Agent 13 in the Spanish Secret Service (New York: Walker, 2009), 76, 106, 119, 128, and 150; Short and Richardson, unpublished manuscript, Short Family Papers, Historical Society; Thomas Marshall Green, The Spanish Conspiracy: a review of the early Spanish movements in the South-West (Ithaca: Cornell University Library, 2009), 326; and William E. Connelley and Ellis M. Coulter, History of Kentucky, in five volumes (American Historical Society, 1922), 1170-1171. Linklater observes that the official business partnership of Short and Wilkinson began in 1790. However, as members of the "anti-Virginia" group of Kentucky's leading men, they clearly associated in some capacity much earlier. Short's position as customs collector at the Louisville junction would have exposed him to the "bribery and forged papers" that were frequently blandished to gain advantage in commercial shipping activities. The "slaughter house" reference appears in John T. Faris, The Romance of Forgotten Men (Freeport, New York: Books for Libraries Press, 1969), 179; and Wade, 25. Ironically, later Symmes's other son-in-law, William Henry Harrison, also became closely involved with Wilkinson-in military affairs and then subsequently as governor of Indiana Territory. Harrison discounted evidence of Wilkinson's involvement in Aaron Burr's supposedly treasonous activities, claiming Burr was "artful and mischievous." Wilkinson extricated himself from that legal imbroglio by providing evidence against Burr to the prosecution. See Owens, Mr. Jeffersons Hammer, in addition to the sources cited above.
} 
doubt to represent the district's interests to a federal government that seemed too often insensitive to western needs. They also partnered in some town development and commercial shipping ventures. It is unclear whether Short's 1789 appointment as customs collector at the Louisville juncture on the Ohio River shipping route appealed to Wilkinson's innumerable schemes, but it may have. When Maria married Peyton that same year, rumors had not yet openly circulated that Wilkinson was also involved in treasonous activities with the Spanish government. After secretly swearing allegiance to Spain, Wilkinson negotiated a private treaty with the governor of Spanish Louisiana, contracting for a near-monopoly of Mississippi River navigation rights for goods originating in Kentucky. ${ }^{21}$

Short shared Wilkinson's imagination that Kentucky district gentlemen's fortunes eventually might be tied more closely to the Spanish than to Virginia or even the new United States, so overwhelmingly focused on its more settled coastal regions. Wilkinson may have admired Short's adventuresome nature, evidenced by Short's late 1780s explorations of the Mississippi River and adjacent regions. The two men partnered in shipping tobacco downriver to New Orleans, the same place Wilkinson negotiated his private navigation agreement. In any event, whether Short knew the depth of Wilkinson's intrigues, he was in thick with some powerful and impressive men, and marked by his own dangerously quixotic disposition. Short's awareness of Wilkinson's full mettle came a few years later when Short alone faced paying large debts he and Wilkinson had incurred jointly, but which Wilkinson avoided by re-entering the military.

\footnotetext{
${ }^{21}$ Speed, 29. The general unsettled nature of the emerging West in the 1770 s and 1780s receives treatment in Patrick Griffin, American Leviathan: Empire, Nation, and Revolutionary Frontier (New York: Hill and Wang, 2007), Chapter Seven and 250. On Short and Wilkinson, again see Short and Richardson, unpublished manuscript, Short Family Papers, Historical Society; Green, 326; Connelley and Coulter, 1170-1171; and Linklater, 76, 106, 119, 128, and 150.
} 
Concerned with the issue of inland waterway access himself, Symmes may not have faulted Short and Wilkinson-treason aside, perhaps-for working all angles seeking commercial transportation, but there was a rumor circulating about Short that could have given Symmes pause. Not long before meeting Maria, Short was involved in a scandal that reverberated widely through gentlemanly circles. While boarding long term with a well-to-do Kentucky family as he scouted business prospects, Short decided that he had met there the love of his life. Only one obstacle blocked the fulfillment of his plan to spend a blissful lifetime with the vivacious twenty-year-old Rachel Donelson Robards: her husband. The large extended Robards family of Virginia transplants lived with Rachel's widowed mother-in-law. Rachel was younger than her husband by ten years, lonely for her own Nashville family, and sometimes friendlier to boarders than decorum suggested. Lewis Robards came to suspect something invidious lurked behind the "extreme politeness" that characterized Short's conversations with his wife. Eventually, he accused them of being secret lovers. ${ }^{22}$

Rachel shortly wound up back at her widowed mother's house in Nashville, fetched by relatives at Robards's request. Meanwhile, Short fled the Robards home toward Virginia, stopping en route to write Rachel and beg her to elope with him to the Spanish territories. He assumed, of course, she would ditch her husband. Short's father had recently died, so Short suggested he leverage his inheritance into cash to fund their escape. A watchful Robards intercepted the letter, however, and set out after Short, intent on receiving satisfaction. Eventually Robards's mother convinced men mutually friendly to Robards and

\footnotetext{
${ }^{22}$ Short's involvement in the Short-Donelson-Robards affair appears in Ann Toplovich, "Marriage, Mayhem, and Presidential Politics: The Robards-Jackson Backcountry Scandal," in Ohio Valley History (Winter, 2005), 3-22; Boynton Merrill, Jr., Jefferson's Nephews: A Frontier Tragedy (Lincoln, Nebraska: University of Nebraska Press, 2004), 170; and Patricia Brady, A Being So Gentle: the Frontier Love Story of Rachel and Andrew Jackson (New York: Palgrave, 2011), 35 and 53. See also Harry Innes to Peyton Short, 21 July 1787 and James Overton Mercer to Peyton Short, 29 June 1788, Short-Symmes-Harrison Papers, Library of Congress. Innes backed out of a business arrangement with Short because of Short's regional reputation after the affair, and Mercer was one of a group of men asked by Robards's mother to intervene in the romantic triangle. General information on the Donelson-Robards dispute and aftermath appears in Robert V. Remini, Andrew Jackson (New York: Harper Perennial, 1966), 20-25, but Short's name does not appear.
} 
Short to write the latter and request that he settle the matter in such a way that Robards would agree to have Rachel back. ${ }^{23}$

Short offered Robards a duel or a cash settlement as satisfaction for "excessive attentions" paid Rachel. Robards, recently pinched for funds, accepted the latter. Initially, Short offered to pay Rachel an annual installment while she remained separated from her husband, clearly hoping for some future contact. However, Robards and their mutual male friends in the region wanted this unsavory matter put to rest, so Short agreed to a larger one-time payment made directly to Robards, and Robards agreed to reconcile with his wife. ${ }^{24}$

Short must have felt crushed when Rachel soon reconciled with Robards, who had joined her in Nashville at her mother's for the time being. He was convinced she did not love Robards, and was probably right. However, pressured by regional gentlemen to let go of his obsession with Rachel, he moved on, and shortly afterward met, then married, Maria Symmes. Within a couple of years, Short may have heard that the Robards marriage failed after all. In Nashville, Robards soon again accused Rachel of attracting the improper attentions of a young gentleman, this time a boarder on her mother's property. After several arguments and a near duel with that boarder, Robards finally stomped away,

\footnotetext{
${ }^{23}$ Ibid. Legal divorces were unusual in early America, rare in the South, and normally the venue of state legislatures rather than courts. Women petitioners almost never received them. Marriages did dissolve, however, often just as many had occurred-informally. Some observers thought people entered in and out of the married state all too frequently, especially in the backcountry, where the primary arbiter of acceptable unions was the immediate society in which they occurred. See Catherine Clinton and Christine Lunardini, The Columbia Guide to American Women in the Nineteenth Century (New York: Columbia University Press, 2000), 64-65. Kentucky District divorce petitions would have been presented to the Virginia legislature, which maintained ultimate control over legal divorce decrees until well into the nineteenth century. See Marylynn Salmon, Women and the Law of Property in Early America (Chapel Hill: University of North Carolina Press, 1986), 63-64; and Toplovich, 3-22.
}

${ }^{24}$ Ibid. 
leaving Rachel and her love interest-a young Tennessee lawyer named Andrew Jackson—to their own devices. ${ }^{25}$

Rumors about the Robards-Short scandal, involving one gentleman's attempt to steal the wife of another, would certainly have made the rounds among well-placed Kentucky and Virginia men. Men's rights to personal property, including wives, were sacrosanct in this period from New England to the Chesapeake. William sent Peyton the name of the best "married attorney" he knew in case a trial ensued, planning that Rachel receive portrayal as the possessor of such charms that no man could hope to escape them. ${ }^{26}$ That is probably the story floated to cover Peyton Short's reputation, and surrounded as he was by impressive gentlemen and high brass like Wilkinson and Scott, perhaps Short's reputation was gradually reclaimed.

Symmes had just gone through his own period of heartbreak before Maria's engagement to Peyton Short. He migrated West despite an intense-and apparently unrequited-love for an unnamed woman back East. He was angry at his inability to stop thinking about her, and if he heard of Short's ill-starred obsession with Rachel Robards, perhaps he sympathized. In any case, Symmes was probably surprised to hear that Maria had attracted a man of such impressive pedigree and charming personality, for it appears Maria did not possess Rachel's charms. Maria was in her latter twenties, several years in advance of the typical marrying age for young women of her background, and well beyond that of most planters' brides. She lacked the gregarious nature and

\footnotetext{
${ }^{25}$ Merrill, 170; and Brady, 35 and 53. See also Harry Innes to Peyton Short, 21 July 1787 and James Overton Mercer to Peyton Short, 29 June 1788, Short-Symmes-Harrison Papers, Library of Congress.

${ }^{26}$ Shackelford, 139. Compare Short's experience to that of a young George Washington, whose amorous attentions to the wife of a close friend apparently raised no great stir in their circle of Virginia aristocrats. See Thomas Fleming, The Intimate Lives of the Founding Fathers (New York: Harper Collins, 2009), 3-18.
} 
vivacity of Rachel Robards, for Maria was "retiring," sickly, sometimes fearful, and prone to completely immerse herself in domestic affairs. ${ }^{27}$

Rapidly marrying in the wake of the Short-Donelson-Robards scandal was the most surefire way to convince observers-especially other gentlemen-that Short had discarded the unruly foolishness of bachelorhood to take on the sober responsibilities of husband and father. Fortunately for Short, Robards did not file suit against him-a necessary step before petitioning the legislature for an act of divorcement-until 1791, two years after his marriage to Maria Symmes. Nonetheless, the action brought the scandal into full public view, if it was not already. The adultery judgment against Short, called in the legal parlance of the day a "criminal conversation," required a thousand dollar payment to Robards and subsequently prompted the Virginia legislature to grant Robards the divorce. ${ }^{28}$ It may have also placed some doubt in Symmes's mind regarding the character of his son-in-law.

Not in doubt would be the appeal Symmes's control of a huge tract of western land had for Short. On the other hand, Short's recent inheritance probably convinced Symmes that this suitor was not one of the myriad Southern gentry whose vaunted reputations far outstripped actual wealth. If Symmes or Maria either one feared she might never attract a husband of appropriate

\footnotetext{
${ }^{27}$ John Cleves Symmes to Richard Clough Anderson, 21 June 1787, Anderson-Latham Family Papers, Filson Historical Society; Michael R. Haines, "The White Population of the United States, 1790-1820," in A Population History of North America, Michael R. Haines and Richard Hall Steckel, Eds., (Cambridge: Cambridge University Press, 2000), 305-370; and Elizabeth Haven Appleton, In Memory of Elizabeth Haven Appleton is Printed this Selection of Her Lectures (Cincinnati: Robert Clarke and Company, 1891), 261; and also see Short and Richardson, unpublished manuscript, Short Family Papers, Filson Historical Society. Remaining in developed Kentucky towns meant Maria did not face the Indian attacks she worried surely awaited her father when he settled on his Ohio land the same year of her marriage.

${ }_{28}$ Papers of Henry Clay vol. 6, Mary W. M. Hargreaves and James F. Hopkins, ed. (Lexington: University Press of Kentucky, 1981), 227; Marquis James, The Life of Andrew Jackson (New York: Garden City Publishing, 1940), 855-856; and Lawrence Stone, Road to Divorce: England, 1537-1987 (Oxford: Oxford University Press, 1990), 231-233.
} 
substance and background, her match to Short resolved those concerns. That the match may have held social benefits for each partner is not to say that the life created for the children who soon arrived was unpleasant. Maria was lonely when Peyton was absent on his countless business excursions and Peyton also missed his family when he was away. And despite the financial misfortunes that dogged the impulsive and careless Short, he situated his family in appropriate comfort in the fashionable Kentucky town of Lexington, where they eventually owned an impressive country estate in addition to a house in town.

If Symmes carried any serious doubts about the match, he did not move on them at the time, if his actions at the later marriage of younger daughter Anna are any indication. Although Symmes had already given Anna his permission to marry William Henry Harrison, he changed his mind and withdrew it. Symmes apparently doubted Harrison's ability to support Anna, despite his impressive Virginia family pedigree. By all accounts, Anna was a remarkably beautiful, serious, and well-educated young woman; certainly Symmes expected she could make any number of favorable matches. When the couple married anyway, Symmes remained estranged from them for a short time. On the other hand, Maria's and Peyton's match proceeded smoothly, and before long Symmes had involved Short-and Short's recent inheritance-in land deals. He also expected Short to lobby Congress on Symmes's behalf regarding his Miami contract. Moreover, Symmes apparently respected Short's judgment early on, for facing a trip to Congress alone, he told Short that he "wished for your counsel. ${ }^{29}$

\footnotetext{
${ }^{29}$ Owens, 39-40; John Cleves Symmes to Peyton Short, 14 November 1796, Short-Symmes-Harrison Papers, Library of Congress; and Short and Richardson, unpublished manuscript, Short Family Papers, Filson Historical Society.
} 


\section{“My Dear Grandsons"}

Symmes was still mourning Maria's untimely death when his dismay only increased, the result of an unfavorable decision by Congress regarding Symmes's request for flexibility on the boundaries of his territorial holdings. ${ }^{30}$ Land purchasers, many of whom now held invalid titles, began to file claims against the judge. The next year, 1803, Symmes was in New Jersey struggling to collect rents from property there when he was arrested on three warrants, the result of suits filed by claimants from that state. Unable to pay bond, Symmes offered his New Jersey homestead, Solitude, to secure the debenture. ${ }^{31}$

Thinking about the possible loss of his New Jersey farm was a melancholy exercise for Symmes. There, almost three decades earlier, he and first wife Anna Tuthill Symmes had joined thirteen-year-old Maria in welcoming baby sister Anna. And there, too, exactly one year later, he and his two daughters grieved their mother's untimely death. Symmes had been left motherless himself as a boy and was subsequently raised by his maternal grandparents. As a recent widower in New Jersey, Symmes had done similarly, and sent toddler Anna into the care of Anna Tuthill Symmes's influential Long Island family. It was a pattern common to Virginia families, too. Upon her death, Maria's children were divided between two sets of Lexington relatives. The boys went to live in one paternal aunt's family, while baby Anna went into the household of another. ${ }^{32}$

\footnotetext{
${ }^{30}$ Bond, Correspondence, 20. Due to Symmes's inability to make scheduled payments on his tract in the Northwest Territory, Congress in 1794 officially reduced Symmes's original purchase between the Greater and Little Miami Rivers by about two-thirds, the amount for which Symmes had already paid. Symmes, ignoring the new boundaries, continued to sell lands beyond them. For details of Symmes's troubled land dealings, see Brown, "'This Unpleasant Business'."

${ }^{31}$ Bond, Intimate Letters, xvii and xviii; and Bond, Correspondence, 21; and Faris, 181-182. Symmes was arrested on three separate warrants, whereby Colonel James Henry, kin-by-marriage and manager of Symmes's New Jersey holdings, bailed him out. Symmes subsequently instructed a son-in-law-presumably Short-to indemnify Henry. As repayment Symmes secretly transferred ownership of his New Jersey estate to said son-in-law, although the transfer was not recorded, ostensibly so New Jersey tenants would continue to pay rent to Henry. Short's later contemplations regarding selling New Jersey lands always met with strong resistance from Symmes, who may have instructed Short to retain them for his Maria's sons.

${ }^{32}$ Symmes's marriage to Anna Tuthill, who came from a prominent New York family, was the first of three favorable matches. Bond, Intimate Letters, xvi-xvii, xxiii.
} 
When Maria died, Symmes already felt fairly beset by financial and legal challenges, as well as the care of his Cincinnati-area farm and demanding requirements of the frontier legal circuit. Nonetheless, he resolved to continue in his imagined patriarchal role and aid Maria's three motherless children. Little Anna was too young to understand the significance of the mail that came regularly from her grandfather addressed to her brothers, but not so the two boys, who were nine and seven when their mother died. Symmes's letter to John and Charles were instructive without being discouraging, lovingly crafted, and always offering his unyielding affection and determination to see his grandsons succeed.

Symmes hoped his enormous speculative undertaking would provide his grandchildren with "not only a tolerable, but an elegant situation." Toward that end, he purchased Ohio Country acreage for them, which, once developed, might generate lifelong rents. The Short boys also owned New Jersey land already producing income that Symmes had provided for them through their mother's estate. Judge Symmes wanted his grandsons to have gentlemanly lives of status and wealth, tempered by the work necessary to successfully pursue rural life in the Ohio River regions. ${ }^{33}$

Symmes also intended for the boys to develop admirable personal qualities. While they were young, he meant to hone their rough edges and to teach them the benefits of gentle manners and kindness. To be "beloved by your fellows," he cautioned, "never be proud and scornful, quarrelsome and fight, nor hard to please [nor] [find]ing fault with every thing that falls in your way. On the contrary you must always be in a pleasant humor, seemingly well pleased with everything. When you see any person in distress pity them. . . [S]uch conduct will

\footnotetext{
${ }^{33}$ Symmes to Charles Short, 7 November 1809 and 23 February 1810, Bond, Intimate Letters, 34 and 35-38.
} 
make every body love you and speak well of you."134 Experienced with the advantages of favorable connections, Symmes knew the value of social graces in creating and maintaining beneficial ties.

Kinship provided the truly reliable bonds, and Symmes underlay his communications to Charles and John with the assumption of family cohesion. Even in the case of step-relatives, he simply made no distinction. After Peyton Short's second wife died in 1808, Symmes comforted his grandsons, referring to Jane Henry Short as their "late deceased mother," a phrase he might have reserved only for his beloved Maria. He always sent his love-once in the form of a "hundred kisses"-to Anna in his letters to John and Charles, courting her affections through them. He encouraged the boys to do likewise: "[A]bove all things, you must love and take care of your dear little sister Anna, when you walk together lead her by the hand ... try to please her and not cross her. . . always carry her ... something good to eat, this will make her love you and always glad to see you." ${ }^{35}$ Of all the characteristics Judge Symmes tried to instill in John and Charles, affection and loyalty toward family were undoubtedly most important to him.

Symmes's primary devotion to family signaled no lack of concern for others, however. Despite his own considerable personal expenses and the cashstrapped nature of frontier life, he was still a frequent benefactor to acquaintances. Settlers to the Miami Purchase sometimes lived on the Symmes homestead until their own property was habitable. Governor Harrison's 1809 visit prompted a round of visits to neighbors and kin. The week ended with breakfast at Symmes's house, where, he said, "I had thirty ladies and gentlemen, men and

\footnotetext{
${ }^{34}$ Symmes to Charles Short, 2 June 1803, Bond, Intimate Letters, 1. Similarly, Thomas Jefferson encouraged his grandson to avoid every argument or dispute. See Jan Lewis, "'The Blessings of Domestic Society'," in Jeffersonian Legacies, ed. Peter S. Onuf (Charlottesville: University Press of Virginia, 1993), 130.

${ }^{35}$ Symmes to John Cleves Short, 21 May 1808, and Symmes to John Cleves Short and Charles Short, 2 June 1803, Bond, Intimate Letters, 26 and 3.
} 
women, workmen and cooks, to eat breakfast with me." Complicating financial matters, Symmes had a penchant for covering orders for friends at area merchants. A typical arrangement was preceded by a note similar to the following: "Mr. Erwin and Co. . . , please to let . . Ezekial Mulford have a small bake oven and a wool hat and charge your friend. John Cleves Symmes." Charles Short doubtless believed his grandfather's assertion that his efforts to secure him a "handsome establishment" might be all the more expected given, noted Symmes, "this I have done for many who were not at all related to me." ${ }^{36}$

Symmes wanted his grandsons to be prepared for the free participation expected of responsible inhabitants of the new nation. Similar to others of the Revolutionary era, he promoted the contemplation of ancient history as a way to achieve that aim. According to Gordon Wood, analyzing dead republics-and especially the natures of their decline-promoted a citizenry resistant to decay and tyranny. Symmes was well-versed himself in classical studies, and encouraged John to peruse Kennet's Roman Antiquities, observing it would be "very entertaining as well as very instructing." He tried for months to locate a copy for the boys, sending in the meantime a "catalogue of the Kings of Rome, most celebrated Dictators, \& Consuls, and of the Roman Emperors," constructed from memory, which he added they should "learn by heart." Symmes eventually sent the boys a copy of Antiquities, including the cautionary notation that the ancient Romans, although a "great people," were still "barbarous and savage" considered beside the "much more civilized" Greeks. Kennet's was a popular didactic classical history, one of many that stressed the connection between

\footnotetext{
${ }^{36}$ Symmes to Jonathan Dayton, 26 May 1791, and Symmes to Mrs. William Henry Harrison, 11 September 1809, Bond, Correspondence, 140 and 297-298; Symmes to Charles Short, 7 November 1809, Bond, Intimate Letters, 34, and also xxx.
} 
decadence and decline, a lesson with broad applications that Symmes no doubt hoped would not be lost on John and Charles ${ }^{37}$

The boys apparently requested a "dissected map of Europe," which Symmes located, although he characterized it as a "mere puzzle-chart, that serves to amuse rather than instruct." Consequently, he sent John extensive details on constructing his own world map on paper, using an existing map or chart as a guide. If he methodically transferred countries and cities to their appropriate latitudes and longitudes, Symmes predicted, John's association of the concepts would be "ever after inseparable." ${ }^{138}$ If Charles had spent the winter of 1808-9 with him, wrote Symmes, "I would have had you so far master of the nautical art, that you. . . [could] have navigated a first rate man of war to the East Indies." ${ }^{139}$ Symmes and the colonizers of Ohio were not parochial men in their outlooks or commercial schemes, and tended to have expansive, even international mind sets. Apart from promoting a well-rounded education, exercises such as these Symmes devised for John and Charles also encouraged the development of cosmopolitan attitudes.

Symmes believed that some of life's important fundamentals were best learned by spending time with him on the farm. He could teach his grandsons "many precepts of oeconomy and industry," he said, "of the greatest service to you through life, but which can never be acquired . . . [except] by practical lessons on a large farm, adapted both for agriculture and stock, and which none can teach but a regularly bred farmer." ${ }^{40}$ Malcomb Rohrbaugh describes the frontier Miami Valley region, which included Cincinnati, as "wealthy and worldly,"

\footnotetext{
${ }^{37}$ Gordon S. Wood, The Creation of the American Republic 1776-1787 (Chapel Hill: University of North Carolina Press, 1969), 6-7, 48-49, 50-53; and Symmes to John Cleves Short and Charles Short, 26 February 1804, 1 April 1804, and 9 May 1804, Bond, Intimate Letters, 7-13.

${ }^{38}$ Symmes to John Cleves Short, 21 October 1804, Bond, Intimate Letters, 16-17.

${ }^{39}$ Symmes to Charles Short, 22 February 1809, Bond, Intimate Letters, 28.

${ }^{40}$ Symmes to Charles Short, 7 November 1809, Bond, Intimate Letters, 34.
} 
was that, but it was also challenging and varied. ${ }^{41}$ His days consisted alternately of building grist mills and fighting barn fires or attending teas and charity theater performances. He tried to convince Charles to stay with him one fall, promising that if the boy would draw him some maps, for which he was "so well qualified," his grandfather would teach him surveying. Measuring cornfields with him, he said, would provide "pretty amusement and instruction for you" and offer his father "no regret" for time lost from school. ${ }^{42}$ Symmes revealed a strong preference for the model of the gentleman farmer, cultured and well-educated, but earnestly familiar with his agricultural pursuits.

Most of all, Symmes wanted his grandsons to love spending time with him, and he constantly wished for their companionship. As the boys grew older, their grandfather became somewhat lonely and disheartened. His third wife, Susanna Livingston, left Symmes and the frontier and returned permanently to her prestigious New York family in $1808 .{ }^{43}$ Long, arduous journeys on the legal circuit kept him from farm duties that were never adequately performed in his absence. His hapless method of land sales made him a considerable number of enemies, especially those whose titles were invalid and had to pay twice for the same land. Symmes suspected that several incidents of arson on his property were the work of disgruntled clients or tenants, especially since some had threatened retaliation when he tried to collect long-overdue rents. Feeling oftentimes discouraged and exposed, Symmes shared his frustrations with the boys over the years, including

\footnotetext{
${ }^{41}$ Malcomb J. Rohrbaugh, The Transappalachian Frontier: People, Societies, and Institutions 1775-1850 (New York: Oxford, 1978), 138.

${ }^{42}$ Symmes to Charles Short, 9 August 1808, Bond, Intimate Letters, 27-28.

${ }^{43}$ Bond, Intimate Letters, xxv-xxvi. A dispute over the management of Susanna's personal finances may have contributed to the dissolution of the Symmes marriage. After Susanna's departure, Symmes ceased mentioning her in his letters. Little is known regarding Symmes's second wife, Mary Henry Halsey, who died before Symmes relocated to Ohio. See Bond, Intimate Letters, xvii.
} 
the difficulty of keeping trustworthy hired help, which sometimes kept him from visiting them. ${ }^{44}$

In essence, Symmes's own frontier community consisted almost entirely of family members, his many other connections notwithstanding. Spread mainly across the trans-Appalachian West, they were his source of emotional wholeness. If kept from seeing them often, he felt their absence intensely. One winter evening, Symmes penned a particularly poignant letter to John. "My dear Grandson," he wrote, "the first thing we did this evening. . . was to drive our cattle to deer-creek \& back again, when I missed you exceedingly, and I fear it will be long before we go again together. ${ }^{45}$

It pleased Symmes immensely that he could do farm work from dawn to dusk well into his sixties, but he provided a balanced masculine example for John and Charles to follow. ${ }^{46}$ His relationship to them was intimate and heartfelt, providing Symmes with a link to his beloved Maria. He encouraged the boys to develop well-rounded associations with each other and their fellows, promoting competition only when the outcome was sure to be mutually beneficial. "Let there be no other strife between you, than ... who shall acquire knowledge most rapidly," he advised. The only vigorously physical pastimes he recommended were solitary ones, such as running or chopping, and he discouraged wrestling and other "violent" exercise. Among "sedentary" pursuits, he recommended the

\footnotetext{
${ }^{44}$ Symmes to Charles Short, 8 March 1809, 9 April 1810, and to John Cleves Short, 3 August 1807, Bond, Intimate Letters, 29-30, 38-40, and 25. See also Symmes to John Cleves Short, 3 March 1811, Bond, Correspondence, 303

${ }^{45}$ Symmes to John Cleves Short, 18 December 1804, Bond, Intimate Letters, 18. Family was important to frontier settlers, according to Andrew Cayton, because it "gave order and predictability to their lives" in the absence of more traditional institutions or communal identities." See Frontier Republic, 4. Carolyn Earle Billingsley suggests that scholars consider kinship as "a discrete category of analysis complementary to and potentially as powerful as race, class, and gender." See Communities of Kinship: Antebellum Families and the Settlement of the Cotton Frontier (Athens, Georgia: University of Georgia Press, 2004), 1.

${ }^{46}$ Symmes to Charles Short, 8 March 1809, Bond, Intimate Letters, 31. "No man is more favored with health than I am," wrote Symmes at sixty-six. "In the morning, I can walk six miles to the point, do a day's work there, and walk home again at night."
} 
"noble game" of chess. Because the outcome did not depend upon "fickle chance," young men would not be "engulfed" in the dangerous habit of gambling. Symmes encouraged Charles to welcome a friend's son to his Lexington boarding school, certain they would develop an "intimate friendship." ${ }^{47}$ Symmes advocated emotionally fulfilling masculine relationships that fostered kindness, mutual benefit, and social cohesion.

Judge Symmes encouraged his grandsons to be affectionate and solicitous to their female relatives, but apparently offered no advice regarding associations with other women. However, he promoted self-control as a sign of respectable masculinity, urging moderation "in all your passions." ${ }^{\text {"8 }}$ Perhaps he intended this oblique reference to cover romantic ardor, as well. Symmes was far from priggish, though. The women in the French settlement at Vincennes were, he wrote to a close, longtime friend, "tolerably inviting," and wore "petticoat short." Situated near the priest's quarters, he observed the "handsomest women. . . go to confess their old sins and contrive to commit new ones." He noted disapprovingly that French women seemed to boss their husbands, who, he predicted, they possibly obliged at night to "observe an humble distance." "Civilized" and "refined" nations", possessing a superior social arrangement, "caressed" and "indulged" their women, he claimed." ${ }^{49}$ Discomfiture with this topic could not be why Symmes omitted it from his instructions on social relations to the grandsons he deemed old enough to participate in decisions regarding their future occupations before this series of letters ends. Apparently he was satisfied that their home environment or the larger socio-familial context provided adequate directions regarding their conduct with potential sweethearts.

\footnotetext{
${ }^{47}$ Symmes to John Cleves Short, 25 March 1805, and to Charles Short, 15 April 1810, Bond, Intimate Letters, 21 and 41-42.

${ }^{48}$ Symmes to Charles Short, 3 July 1810, Bond, Intimate Letters, 43.

${ }^{49}$ Symmes to Robert Morris, 22 June 1790, Bond, Correspondence, 287-290.
} 


\section{"Cruelly Disinherited"}

Symmes, whose Massachusetts ancestors had attended Harvard, expressed pleasure when seventeen-year-old John arrived in New Jersey in 1809 to begin studies at Princeton. There, predicted Symmes, "you will meet with hundreds who are acquainted with your grand-pah." He hoped Charles, then 15, would soon follow John's example..$^{50}$ The previous year, their stepmother of six years died a few months after the birth of a baby son, whose death followed four months later. Peyton's marriage earlier to Jane Henry Short had only cemented the Henrys of New Jersey society to the Short and Symmes families, as Jane had been not only Maria's dear friend, but the sister of Symmes's second wife, as well. Jane's demise left the boys and their sister, as well as several younger halfsiblings, without a mother. Fortunately, her mother-whom Symmes always called Mama Henry-remained in the Short home and continued to oversee the family. Probably much to her relief, the boys spent much of their time away at schools. So by the time John went off to Princeton, fulfilling the dearest hopes of his grandfather and father, the family seemed to be doing fairly well, despite the recent death of Jane Short. However, a family crisis that began late that year soon changed the complexion of Judge Symmes's concern for the boys. Their father, through unsuccessful land speculations and injudicious business agreements, suffered a spectacular financial collapse. ${ }^{51}$

Peyton Short was similar to many speculators, perceiving themselves a landed gentry who sometimes faced real estate payments or taxes beyond what they could collect promptly. Indeed, the ubiquitous shortage of specie in the emerging West almost guaranteed speculators would occasionally find

\footnotetext{
${ }^{50}$ Symmes to John Cleves Short, 1 January 1806, and to Charles Short, 22 February 1809, Bond, Intimate Letters, 22 and 18.

51Detailed genealogical and other information relating to the Short, Symmes, and Henry family connections appears in Short and Richardson, unpublished manuscript, Short Family Papers, Filson Historical Society.
} 
themselves in this position. When that occurred, gentlemen in Short's circle often asked a friend to cover for them or simply sold other holdings to raise cash. The Virginia gentry were notorious for loosely made business arrangements, promises to cover for each other, and a strong hesitance to approach friends to collect debts. Attempting the latter could imply that the man inquiring about the debt doubted a fellow gentleman's word that he intended to repay it. The men in Short's world apologized dramatically when they originated debt repayment inquiries, always assuring the debtor that only their extreme present shortness of cash could induce them to even mention the matter. Successful relationships in many cases depended less on actually managing their business affairs effectively, which few did, than on promoting-and protecting-reputations as men of honor. ${ }^{52}$

Despite his large land holdings in Ohio, Kentucky, and New Jersey, Peyton Short found himself in late 1809 in a real financial mess. He had overestimated his speculative abilities, even in Symmes's Miami Purchase, and payments came due well beyond what he could cover by the usual means. Short thought he also saw a way around his dilemma. He decided to sell his plantation outside Lexington, which would also allow him to concentrate his family at their house in town. What Short did not tell the buyer was that he had secretly placed a lien on part of that property to guarantee another debt. Short hoped that he could use the earliest payments on the plantation to quietly remove the lien, but the holder of the lien revealed the scheme. Feeling duped, the potential buyer of the plantation noised Short's secret machinations and walked away from the deal. $^{53}$

${ }^{52}$ Kenneth S. Greenberg also recognizes this honor-based system of personal loans and relates it to the larger culture of planter gifts that maintained their superiority as a class. See Honor and Slavery: Lies, Duels, Noses, Masks, Dressing as a Woman, Gifts, Strangers, Humanitarianism, Death, Slave Rebellions, the Proslavery Argument, Baseball, Hunting, Gambling in the Old South (Princeton: Princeton University Press, 1996), 78-80.

${ }^{53}$ The details of Short's financial collapse, and his reaction to it, are mainly found in his letters to Frederick Ridgeley and Charles Wilkins in late 1809 and 1810 in the Short-Symmes-Harrison Papers, Library of 
Short knew his masculine world of landed gentlemen might now view him as a schemer, not a man of honor who they could trust in business dealings. Moreover, he expected every man to whom Short owed money would rush to collect before Short's assets were finally depleted, possibly leading to his family's complete devastation. As he later explained, this "derangement of my finances. . . produced a restlessness among my creditors. . . . and excite[d] an alarm in the heart of every man to whom I owed a schilling." At the time, Short envisioned his family "turned into the streets without a way to cover their heads or a cent wherewith to buy them bread." Previously, Short was a man of prestige, owning as he did one of Kentucky's finest estates, "well stocked" with slaves and cattle. In a "fatal dilemma" and with his precious reputation crumbling, he now feared others might view him as a man "standing on the brink of ruin.".54

Deranged with panic, Short hastily devised a way to extricate himself from the swirl of horrible events about to crash down on him: he ran. Drawing up a letter assigning power of attorney to the boys' two Lexington uncles-each married to one of Peyton's sisters-Short mounted his horse and at first headed away from Lexington toward other lands he owned and managed in Kentucky. There, he unexpectedly collected two hundred dollars and, as he later told it, began to realize that he could live as cheaply traveling on his horse as at home. So off Short went on a grand tour, also scouting for profitable lands in which he thought he might later speculate to restore his fortune. He wandered through states and territories in a huge circle that took well over a year to trace and came

Congress. However, letters exchanged between other men in Peyton's circle during that period illuminate the details considerably.

54 Peyton Short, undated statement, Short-Symmes-Harrison Papers, Library of Congress. This document appears to have been written in late 1809 or early 1810 and was probably included in a letter to either Frederick Ridgeley or Charles Wilkins. Also see Peyton Short to Messr's Charles Wilkins or Doctor Frederick Ridgeley, 22 October 1809, Short-Symmes-Harrison Papers, Library of Congress; and Short and Richardson, unpublished manuscript, Short Family Papers, Filson Historical Society. 
nowhere near Kentucky. This behavior represented the essence of Peyton Short, impulsive dreamer and failed chaser of grand schemes and fast fortunes. ${ }^{55}$

The escape route the panicked Short followed was initially similar to the one he had suggested to Rachel Robards as he planned their hasty flight together from her husband: the Spanish south. The 1803 Louisiana Purchase had since added much of the lower Mississippi Valley to United States holdings, but Short did not stop there. He travelled on to Florida, still under Spanish control, and became entranced with the possibility of pursuing a life of true opulence there with much smaller investment.

Short had left a few dollars and some store credit with the aging Mama Henry, who had overseen his household since Jane's death the previous year. Periodically he wrote the boys' uncles, begging them to take special pity on his family, watch over them, and understand Short's special predicament. On one occasion he wrote,

Having as yet heard nothing from you ... I have not much to say in regard to my business. I can only say I hope you have been at least a friend to my poor dear bereaved children, and that you will do the best you can for their interest and happiness. For my part I know not what to say as to myself. My heart sinks within me whenever I think of my poor distressed family and my deranged affairs. I am distracted to see them until the stain in some measure subsides at home. I shall, however, in the meantime, should an occasion offer, by some bold effort, either regain my former standing in society or sink forever in the attempt. I can say no more at present than throw up my prayers to heaven for the health and welfare of yourself and family, and may God cast a pitying eye on the dear, dear children of your fortunate friend and humble servant. ${ }^{56}$

55 Joan Cashin notes that the friends and relatives of males migrating to the frontier Southwest sometimes described them as "impulsive," or of an "unsettled disposition." She also describes some of them as "obsessive." See A Family Venture: Men and Women on the Southern Frontier (Baltimore: Johns Hopkins University Press, 1994), 36.

${ }^{56}$ Peyton Short to Frederick Ridgeley, 22 December 1809, Short-Symmes-Harrison Papers, Library of Congress. 
The uncles were frustrated that contacting Short proved impossible, as before they could send a reply to the few letters they received from him, Short was off again toward an unknown destination. Uncertain of exactly how his children and extended family felt about him now, Short pled with Ridgeley to "consider me . . . as dead and consider my dear children as bereaved orphans ... consigned to the mercy of the world." Although he longed to hear that his children fared acceptably, Short's travel pattern did not allow mail to reach him efficiently, possibly because he also wished to avoid being reminded of the responsibilities he left behind. ${ }^{57}$ It all became too much for poor old Mrs. Henry, however, who died during Peyton's absence. Once again, the younger children were all divided among kindly relatives in the Lexington area. Fortunately, John and Charles were already spending much of their time boarding at school.

Symmes was furious, even before he realized what would be the eventual length of Short's flight from his personal reality. For one thing, Symmes had wanted rents on some New Jersey lands to pay John's way through Princeton and support him while there. Before his collapse, however, Short had begun sale on those lands. The would-be buyers, hearing of Short's downfall and worried their land titles would become entangled in Short's financial nightmare, got Short's permission to withhold payments until John reached legal age. Symmes forgot his earlier caveat to the boys that gentlemen never speak ill of others. In letters to them he railed against Peyton's "imprudence" and "cruelty," charging that he had effectively "disinherited" John and Charles. ${ }^{58}$ Peyton Short apparently

\footnotetext{
${ }^{57}$ Peyton Short to Frederick Ridgeley, 20 January 1810, Short-Symmes-Harrison Papers, Library of Congress. The actual date written on the letter is 1809 , but its contents demonstrate that this date is in error, and probably Short wrote 1809 out of habit, not having adjusted to the new year yet.

${ }^{58}$ Symmes to Charles Short, 23 February 1810 and 3 July 1810, Bond, Intimate Letters, 36 and 43 . Also see Symmes to Charles Short, 4 January 1815, Short-Symmes-Harrison Papers, Library of Congress. Ironically, Short lost part of his fortune investing in Symmes's own Miami tract, implying a certain mockery in Symmes's charges against Peyton Short. Short also may have been a poor judge of men with whom he dealt, a failing Symmes did not possess. He leaned too far the other way, trusting almost no one to assist with his business affairs. The responsibilities overwhelmed him, leading to numerous errors that eventually contributed to the lawsuits against him and his own financial collapse. By 1810, word was circulating that associating financially with son-in-law Peyton Short had also somehow contributed to the demise of Mrs.
} 
crossed a line that signaled he no longer deserved treatment as a gentleman, even before his own sons. Symmes drew that boundary at risking a child's fortunes along with a father's own. Certainly, that man forfeited the respect and social protection of his fellows, irrespective of his background and bearing.

Symmes's correspondence acquired an urgent tone for the next two years as he desperately sought to bring John home and effect a plan for both boys' futures. Their calamitous financial outlook and Symmes's own fiscal crisis that resulted from his failed land dealings forced the conclusion that a young man without enough property already in hand to guarantee his support should train for a successful professional career and leverage connections to the regional elite.

In the meantime, Peyton chased other speculative ventures while from Lexington the boy's two local uncles-by-marriage oversaw the disposition of Peyton's children. Prominent physician Frederick Ridgeley and Charles Wilkins, a successful merchant, deserved the boys' complete cooperation and obedience, urged Symmes. Peyton's apparent removal from the process of resolving the boys' futures allowed other male relatives-specifically Symmes and the two uncles - to claim de facto fatherly roles. Occasionally, Symmes offered that the boys might make their own career choices, but he was more comfortable asserting his grandfatherly position as family patriarch. Finish your schooling, he urged Charles, and then "fly immediately to me." If the uncles approved, Symmes proposed bringing both boys to Ohio so he could "form [his] own opinion of [their] respective talents" and acquaint them "with the country and the more respectable parts of the inhabitants" there. ${ }^{59}$

Henry's personal wealth. See James Henry to Charles Wilkins, 26 January 1810, Short-Symmes-Harrison Papers, Library of Congress. In years to come, Peyton Short and sons believed Henry, the longtime agent managing the Symmes ancestral New Jersey properties, inappropriately transferred funds into his own "omnivorous clutches." Charles Short to John Short, 29 November 1853, Short-Symmes-Harrison Papers, Library of Congress.

${ }^{59}$ Symmes to Charles Short, 7 November 1809, Bond, Intimate Letters, 33-34 (and note). 
During this uncertain period, a benevolent and gentlemanly competition ensued as Symmes and the uncles Ridgeley and Wilkins negotiated their respective roles in charting a future course for John and Charles. Unfortunately, Peyton's very wealthy and influential older brother, William, was again residing overseas when the calamity hit. Ridgeley visited Symmes briefly to report the alarming state of affairs. Later Symmes, observing that letters to Lexington were going unanswered, suspected he was being left out of the process. He was partly right. Remaining loyal to Peyton, the uncles confided to William Short that they meant just to "indulge the old man" until Peyton give them directions regarding John's future course. Moreover, Wilkins confided that they also feared crossing Symmes too much might "enrage" Symmes and thereby endanger the "expectation" of John and his family to receive some inheritance from Symmes. Granting that their uncles had "the welfare of [John and Charles] as much at heart as is possible for the best of men to have," Symmes still confided to Charles, "[y]et I fear that we may not perfectly agree as to the measures that are to be pursued." Symmes may have overasserted his patriarchal authority early on. "John must be a lawyer," he had insisted previously to Charles, "but what I shall make of you, my dear grandson, I can better decide when you come to live with me." The tug-of-war over directing the boys' futures abated while Peyton continued to roam. For the time being, John would live with his grandfather and study law, although the two Lexington uncles viewed time with Symmes "not profitably spent." A conciliatory Symmes wrote Charles to disregard his earlier instructions to join him in Ohio: "I now release you of this call."

\footnotetext{
${ }^{60}$ Symmes to Charles Short, 9 April 1810, 23 February 1810, and 14 April 1810, Bond, Intimate Letters, 35-42. Also see wwCharles Wilkins to William Short, 25 October 1810, Short Family Papers, Filson Historical Society. William Short returned stateside during Peyton's wandering sojourn, and even met with his younger brother in New York, but Peyton did not reveal to him the state of his affairs. Charles Wilkins later wrote William that Peyton's "fake pride still prevails, an aversion to make known his situation to his friends has contributed not a little to embarrass his affairs." See Charles Wilkins to William Short, 30 September 1810, Short Family Papers, Filson Historical Society.
} 
Symmes, who promoted farming as a source of valuable "practical lessons," presented Charles three decidedly-non agrarian career choices: "Law, physic [i.e., medicine], and commerce are open before you." "While I live," he added, "I can aid you in either which you may prefer."161 Obviously, Symmes could provide alliances and guidance for a young man pursuing a law career. However, Symmes's assertion that he could position Charles favorably in commerce or medicine may underscore a desire to leverage his involvement in the boys' futures. Their two uncles, already successful in those very occupations, probably presented more chance for patronage and favorable connections in those fields. Symmes, however, claimed that the boys could not "live in Kentucky reputably without Negroes," and commanded that John and Charles "must both settle on this side of the Ohio." He encouraged the boys to consider the merits inherent in an alternate system where "a man . . . may go from the bench of the supreme court to his woodpile" and still maintain the respect of his fellows. ${ }^{62}$ This position carried the clear advantage of further encouraging John and Charles to reside outside Kentucky.

Illusions about the reliability of entrepreneurial land speculation now dissipated, Symmes was apparently willing to consider other forms of "commerce" as potential careers for Charles, although he did not address that topic directly. On other hand, Symmes clearly approved of careers in law or medicine. As true professions, both were occupations voluntarily regulated by practitioners, and this level of structural autonomy asserted a high degree of social responsibility and trustworthiness, for, according to Daniel Calhoun, "professional men stood as gatekeepers in a fast-growing, ill-organized society."63

\footnotetext{
${ }^{61}$ Symmes to Charles Short, 23 February 1810, Bond, Intimate Letters, 38.

${ }^{62}$ Symmes to Charles Short, 9 April 1810, Bond, 39.

${ }^{63}$ Daniel H. Calhoun, Professional Lives in America: Structure and Aspiration 1750-1850 (Cambridge: Harvard University Press, 1965), 4. There exists no clear historiographical lineage regarding frontier lawyers and
} 
Recognizing law as the source of authority, people allowed the legal order a distinctive claim to "place and power in the republic." ${ }^{\text {"S4 }}$ Symmes asserted law's primacy among careers while the boys were very young. Becoming scholars in "books and science," he claimed, would help make them "great as well as good men." The state might then confer upon them the ultimate tribute and make them "judges or members of Congress, [or] something still higher." Men elevated to such positions controlled the flow of justice and law in the republic, and Symmes encouraged his grandsons to "learn men and the world" in anticipation that they might someday participate in that exchange. Granted, true gentlemen did not practice law as their main source of income, but when that necessity changed, it was a valuable asset to any gentleman's overall education. On the more practical side, Symmes recognized the relative ease with which he could prepare either grandson for a law career. Even though Ohio law, as of 1799, regulated access to the bar, it did so without requiring education beyond apprenticeship and deferred decision-making to other legal practitioners. Symmes had saved his law library for John's eventual use, and, although continually lacking cash, he expected he could pay for John's apprenticeship in a colleague's office with land or horses. ${ }^{65}$

The legal and medical occupations shared one very important concern for Symmes. A lack of clear training structures in prior decades had left the new republic with too many practitioners in each field characterized mainly by their incompetence. Symmes respected the style of medical professionalism modeled

their world. For an assessment of why that is the case see Cathy Rodabaugh, "Where Have All the Lawyers Gone from the American Frontier?," unpublished essay.

${ }^{64}$ Michael Grossberg, "Institutionalizing Masculinity: The Law as a masculine Profession," in Meanings for Manhood: Constructions of Masculinity in Victorian America, Mark C. Carnes and Clyde Griffen, eds. (Chicago: University of Chicago Press, 1990), 134.

${ }^{65}$ Symmes to Charles Short, 2 June 1803, and 23 February 1810, 2 and 37. Also see Watson, 150. On gentlemen and law practice, see Gordon S. Wood, The Radicalism of the American Revolution (New York: Vintage Books, 1991), 344. 
by the boys' "kind and skilful Uncle Ridgeley," however. By contrast, those unfortunate souls struck ill at the Symmes homestead would probably have "a drunken woman attend" them. In the unlikely event that he could procure much better, Symmes observed, his doctor was "but a mere quack" compared to Ridgeley. ${ }^{66}$ In Symmes's view, another bane of the developing frontier was its overpopulation with unqualified lawyers. Increasing nearly four times as fast as the population in the post-Revolutionary period, the bar was, according to Symmes, "already crowded with men who call themselves lawyers," most of whom had "none of the attributes." He would rather that John be "no lawyer, than . . . only of the second grade." Despite a rising emphasis on formal education in preparing men for the professions, Symmes, recognizing John could continue no longer at Princeton, defended simultaneously his own legal training and the continued reliability of legal apprenticeships. Besides, he consoled, a "kind of mental rust [was] contracted within the damp walls of a college," and Princeton was, after all, a "hot bed of federalism." 67

Interestingly, Symmes did not suggest that John or Charles consider some occupations in which family members had also been heavily involved, the most obvious being property investment. The recent experiences of Symmes and Peyton Short only emphasized the potential peril attached to relying too heavily on land speculation as a primary source of income. Although Symmes consistently maintained governmental shortsightedness produced his own financial difficulties, he believed Peyton's downfall was largely due to his own credulity, making him and others of imperfect judgment the special prey of men ever poised to take advantage. "[B]e ever on your guard," Symmes warned John, as he prepared him to set out on his own. "[T]his is an age for swindling."18

\footnotetext{
${ }^{66}$ Calhoun, Professional Lives, and Symmes to Charles Short, 14 December 1810, 45.

${ }^{67}$ Grossberg, 134; Symmes to Charles Short 9 April 1810 and 23 February 1810, Bond, Intimate Letters, 36-39.

${ }^{68}$ Symmes to John Cleves Short, 3 July 1810, Bond, Intimate Letters, 43.
} 
Symmes omitted comment regarding the noteworthy military career of the boys' only maternal uncle, Indiana territorial governor William Henry Harrison, an obvious potential source of patronage for young men considering a military occupation. ${ }^{69}$ Although he liked the topic of martial history, apparently Symmes did not write about his own fairly extensive military experience or the lurid details of the Indian conflicts just passed, with which he was very familiar. ${ }^{70}$ Despite a growing emphasis in the military on skill rather than strength, Symmes had written in 1804, "war is [and] always was a curse to mankind, [and] it is a great pity that all mankind are not Quakers." Compare that comment, however, with one made to a friend during the Indian wars of the 1790s. It was "to the honor of many young gentlemen of that Society," he said, that some Quaker youths had marched with the local militia, and now risked, with their parents, banishment from the sect. ${ }^{71}$

Symmes viewed military service as an honorable venture, but he frowned upon the pursuit of that avocation without other occupational interests. Indeed, that was part of his initial concern about having Harrison as a son-in-law years ago, so no doubt he recognized the potential vagaries of fortune adhering to a military career, especially where there existed no tradition of a large standing army. In fact, despite Harrison's rapid rise in rank and esteem in the military, he also knew that a soldier's modest pay sometimes could be hard to collect. This was certainly not a career that could repair the boys' damaged fortunes. Moreover, Symmes also may have wanted to discourage any youthful tendency

\footnotetext{
${ }^{69}$ Harrison continued to distinguish himself not only politically, but also militarily, acting as Commander-in-Chief of the Army of the Northwest during the War of 1812.

${ }^{70}$ Even though the army's "shameful" and infamous St. Clair-led 1791 defeat by Indians took place so close to Symmes's holdings that people were afraid to settle there, Symmes still wrote nothing of his own intense interest in recent military affairs to his grandchildren. Symmes to Jonathan Dayton, 15 August 1791 and 17 January 1792, Bond, Correspondence, 150 and 158.

${ }^{71}$ Symmes to John Cleves and Charles Short, 9 May 1804, Bond, Intimate Letters, 13; and Symmes to Jonathan Dayton, 30 September 1794, Bond, Correspondence, 167. In a 30 October 1812 letter to John, Peyton reminds John that he never liked the military as a profession and had told the boys so several times in the past. See in the Short-Symmes-Harrison Papers, Library of Congress.
} 
to imagine military life as romantic, also protecting his grandsons from harm. Harrison was, after all, then at the forefront of the federal government's drive to deal with resistant Indians in the remaining parts of the Old Northwest. ${ }^{72}$

Symmes also did not suggest an ecclesiastical career for either grandson, an instructive omission considering the noteworthy contribution of his New England forbears to that vocation. Symmes had once written the boys that his ancestors included men who were "ornaments of the pulpit and bar." Many family forerunners of this missionary's son had been ministers; indeed, his great-great grandfather was one of the earliest clergymen in colonial Massachusetts." ${ }^{173}$ One of the most respected professions in the early republic, alongside the practices of law and medicine, a clerical vocation still did not hold the same potential for personal economic stability. Fewer churches provided patronage in the form of guaranteed long-term appointments that had existed commonly in the eighteenth century. Moreover, the socioeconomic fluidity of the frontier augured demonstrable benefit for professions tied more directly to the burgeoning market economy. ${ }^{74}$ In any event, Symmes cared little for organized religion, despite the many options for affiliation the Cincinnati region offered. Apparently rejecting them all, he concluded that "the best religion after all is to fear God and do all the good we can to ... mankind." He once noted wryly to daughter Anna his "consolation" that one hundred "ecclesiastics" expected to convene soon in Cincinnati would be kept "in order" by the Supreme Court, scheduled to sit at the

${ }^{72}$ Symmes to Silas Condict, 28 February 1796, Bond, Intimate Letters, 102; Calhoun, 16-17; Owens, 39-41; and Nancy Beck Young, "Anna Tuthill Symmes Harrison," in Presidential Wives, an Anecdotal History, Paul F. Boller, ed. (New York: Oxford University Press, 1998), 76. Owens and Young both recount the supposed incident wherein Symmes, seeing Harrison for the first time after the marriage of which Symmes disapproved, challenged Harrison regarding how he expected to support his new wife. Harrison supposedly gestured to his sword and gallantly declared it his sole means of support. On Harrison's general significance in the Old Northwest, see Owens.

${ }^{73}$ Symmes to Mrs. William Henry Harrison, 7 August 1802, Bond, Correspondence, 295-296; and Symmes to Charles Short, 8 March 1809, reprinted in Short and Richardson, unpublished manuscript, Short Family Papers, Filson Historical Society.

${ }^{74}$ Calhoun, 88-89. 
same time. ${ }^{75}$ Judge Symmes was not impious, however, and maintained a certain resolution to God's will. For a time in 1810, John was so ill the doctor characterized his case as "almost hopeless." But, wrote Symmes to a worried Charles, "all that I can do is . . seal my lips in silence [and] profound adoration of that divine being, in whose hand is the breath of every living mortal. ${ }^{76}$

Above all, Symmes's concern for the boys' future plans following Peyton's monetary crisis -apart from John's return to health—was their financial security. Choosing marketable professions became the foundation of that strategy. Now without independent means of support, John and Charles would have to compete in a rapidly changing environment. But they would still compete as gentlemen, if Judge Symmes had any say. Trusting few and with family as their primary base of social cohesion, they were "doubly called upon to exert [them]selves" to remedy their father's "folly." With "application to oeconomy and business," Judge Symmes predicted his grandsons might still go "through life in very easy circumstances." 77

Symmes still emphasized the basic tenants of good behavior: "[B]e studious, be prudent, careful and wise. . . waste nothing. . . improve yourself also in suavity of manners, be moderate in all your passions, genteel in your deportment. . . . [J]ustify yourself by your deeds and others will . . . justify you in loud praises." The benefits of virtue were as axiomatic to Symmes as they were to Benjamin Franklin, who advocated "Industry and Frugality, as the means of procuring Wealth." In either case, men achieved success by developing admirable traits, although Symmes's maxims existed alongside a reminder of the value of appearances and advantageous connections. John Cawelti presents

\footnotetext{
${ }^{75}$ Symmes to Mrs. William Henry Harrison, 17 September 1809, Bond, Correspondence, 297.

${ }^{76}$ Symmes to Charles Short, 14 December 1810, Bond, Intimate Letters, 46.

${ }^{77}$ Symmes to Charles Short, 7 November 1809, 3 July 1810, and 9 April 1810, Bond, Intimate Letters, 34, 43, and 39 .
} 
Franklin as the prototype of the American self-made man, a concept that scholars believe required a near-mythological construction in every age. ${ }^{78}$ Symmes projected an image of masculine success bearing more resemblance to a self-monitored man than the almost total self-reliance asserted in the folklore of American character formation.

Symmes presented his masculine ideal as an organic whole, never separating the encouragement of personal virtues and social graces from instruction on how to make and save money. Creating a good impression was very important: "[K]eep yourself erect while standing, sitting, or riding. . . . keep yourself always clean and neat, your hair combed, your shoes black. . . . In plainness of your dress be a Shaker-in ease and politeness be a Chesterfield. ${ }^{179}$ In Symmes's mind, all was pragmatic, designed to not only win his grandsons general respect, but to maintain a lifestyle that identified them with the elite, the wellspring from which potential patronage and favorable marriages flowed. Inability to guarantee socioeconomic status for John and Charles panicked Symmes when Peyton Short's investments collapsed. The crisis not only endangered the boys' financial futures, but-equally vital to their eventual well-being in Symmes's mind-their ability to maintain the acceptance and respect of their neighbors and peers.

In many ways, Symmes's idealization of masculine behavior resembles a more sincere version of Castiglione's Courtier, who became the model for

\footnotetext{
${ }^{78}$ Symmes to Charles Short, 3 July 1810, Bond, Intimate Letters, 42-44; and Benjamin Franklin, Memoirs, quoted in John G. Cawelti, The Apostles of the Self-Made Man (Chicago: University of Chicago Press, 1965), 16. Also see chapter one on Franklin as the model of the American self-made man.

${ }^{79}$ Symmes to Charles Short, 3 July 1810, Bond, Intimate Letters, 3 July 1810, 43-44. Craig Thompson Friend observes the role Lord Chesterfield's Advice to His Son on Men and Manners, popular with American audiences beginning in the 1790 s, played in showing young men the importance of outward behaviors to demonstrating status as gentlemen. See "Belles, Benefactors, and Blacksmith's Son: Cyrus Stuart and the Enigma of Southern Gentlemanliness," in Southern Manhood: Perspectives on Masculinity in the Old South, Craig Thompson Friend and Lorri Glover, Eds. (Athens, Georgia: University of Georgia Press, 2004), 100. Also see, from that same anthology, Lorri Glover, "Let Us Manufacture Men": Educating Elite Boys in the Early National South," 29.
} 
Renaissance nobility throughout Europe. The scholarly and decorous man-ofaction may find his appeal in every age. On the other hand, the model of the "many-sided" Renaissance man placed before Judge Symmes's grandsons, while certainly less brazenly opportunistic than Castiglione's version of the ultimate gentleman, still carried practical applications, even for a frontier setting. The boys' grandfather recognized the interconnectedness of their social sphere with the broader, more influential world of the eastern United States. While Symmes could not imagine that he or his grandsons would ever desire removal from the Ohio River regions, he certainly did not envision any necessity to rend advantageous social or political ties to New York or Virginia. ${ }^{80}$

\section{Conclusion: Patrimony and Memory}

Given Peyton Short's fine education, noteworthy social graces and pedigree, plus Lexington's reputation as a regional cultural center and the presence of devoted kin there, it seems almost remarkable that Symmes felt so compelled to instruct the boys in such careful detail. Perhaps he feared they might follow in the paths of those many planters' sons who became unruly and profligate before finally settling down. On the other hand, Peyton also wrote them occasionally regarding proper conduct, and although his letters were much shorter and not nearly as didactic as Symmes's, they were still very clear about expectations of generally respectful behavior. Lorri Glover maintains that "drinking, gambling, sexual experimentation, and dueling and other forms of orchestrated violence" were "accepted and even encouraged in Southern male culture" and did not negatively impact a man's place in "genteel society."

${ }^{80}$ Baldesar Castiglione, The Book of the Courtier, trans. George Bull (Middlesex, England: Penguin Books, 1980), 14-17. For a discussion of the influence of cosmopolitan or national experiences versus regional (Virginia) ties upon competing political alignments among Ohio's founders, see Andrew R. L. Cayton, "Land, Power, and Reputation: The Cultural Dimension of Politics in the Ohio Country," William and Mary Quarterly, 3rd. ser., Vol. 47, No. 2 (Apr., 1990), 266-286. Consistent with his historical reputation as a crank, Symmes does not fit comfortably into either of Cayton's model groups of influential early Ohioans, and he mentions him only in passing. 
However, there is no evidence that either of the Short boys was then-or everprone to such behaviors. On the other hand, "Southern scions" were typically raised "with a strong sense of self-satisfaction and little inclination toward obedience." Symmes clearly felt the boys would benefit from his influence, especially after Maria's death. Short had offered to duel with Robards over the affections of Rachel, and in the lack of self-awareness that seems central to Symmes's nature, perhaps he viewed Short's risky business ventures as evidence of a planter's gambling mindset. In any case, Symmes put a lot more of his instructions to paper than did Short, and those he did are not only much more detailed, but encouraged behaviors decidedly opposite those that characterized many elite young men in the early national South. ${ }^{81}$

When Maria married a Virginia planter's son and removed to Lexington, Symmes bemoaned her situation in a letter to James Henry, the uncle of Symmes's deceased second wife. "Poor, dear Maria, she seems lost to us all, and buried at Lexington in a circle of strangers. She would not come here with me. . . ; the fear of the Indians deters her." ${ }^{82}$ Symmes viewed the New Jersey Henry clan as part of his own extended family circle, but clearly he had trouble envisioning the "strangers" among whom Maria was metaphorically "buried"including her new husband's acquaintances-in quite the same potential light. For a man such as Symmes, used to traveling in the West and broadly acquainted with influential men from all parts of the new nation, this seems a rather parochial statement, unless Symmes felt some kind of permanent chasm existed. Without being overtly chauvinistic, Symmes still obviously preferred

${ }^{81}$ Lorri Glover, "'Let Us Manufacture Men'," 22-47; and Southern Sons: Becoming Men in the New Nation (Baltimore: Johns Hopkins, 2007), 28. Also see Bertram Wyatt-Brown, Southern Honor: Ethics and Behavior in the Old South (Oxford: Oxford University Press, 1982, 161-165.

82 Quoted in Elizabeth Haven Appleton, In Memory of Elizabeth Haven Appleton is Printed this Selection of Her Lectures (Cincinnati: Robert Clarke and Company, 1891), 261. Years later, Symmes contrasted caring relatives with the "strangers" that made up his Ohio homestead "family," as households were often also called. Symmes said these "strangers" were "in no way interested in my prosperity." See John Cleves Symmes to Charles Short, 9 April 1810, William Henry Harrison Papers, Indiana Historical Society. 
Northern life to that exemplified by the Southern gentry. By the time his other daughter also married one of Virginia's westering sons, Symmes knew he would have to make the best of it to remain close to his daughters and their children.

Given that Maria's relatives all lived so far away, after her death Symmes probably hoped to provide some sense that meaningful influences in the boys' lives still came from his side of the family. In a sense, they were now "buried" among those same people Symmes could once only envision as strangers, despite Maria's living among them. No doubt Symmes also suspected that as a child he had missed out on something in the absence of his parents, as had fouryear-old Anna when she went to live with the parents of Symmes's deceased wife. Moreover, in each of those circumstances it was grandparents who had taken on the obligation of childrearing. Symmes may have worried that Virginia planter ways would prevail without Maria's potentially tempering influence, especially given that the boys' two devoted Lexington aunts were Short's sisters. Through his daughters' marriages the Symmes family became deeply intertwined with the Virginia migrant culture of the Kentucky and the Ohio Valley. In fact, Kentucky affairs were dominated by transplanted Virginia planters' sons almost from the start. Still, Symmes occasionally assessed his grandsons' upbringing there by contrasting it with his own Yankee beginning. Symmes thought the boys started their school studies too late; Symmes had begun before he was even three years old. Widowed Virginia planters were notorious for stashing children with relatives, then "dissipating" their way to another wife, even if barely able to support the first family. Given what happened in the boys' lives, it would be easy for Symmes to worry whether Short had the wherewithal to see adequately to the boys' futures when he began his second family, and Symmes certainly knew otherwise by $1810 .{ }^{83}$

\footnotetext{
${ }^{83}$ John Cleves Symmes to Anna Symmes Harrison, 10 December 1802, William Henry Harrison Papers, Indiana Historical Society. On the prominence of transplanted Virginia planters to Kentucky and their dominance there see David Hackett Fischer and James C. Kelley, Bound Away: Virginia and the Westward Movement (Charlottesville, Virginia: University of Virginia Press, 2000), especially page 159. The "dissipating" comment
} 
Actually, John Cleves Symmes and Peyton Short were more alike than Symmes ever would have been willing to admit. They often instructed the boys in fairly very similar fashion, emphasizing classical history and diligence in studies, standard training for prospective gentlemen in the early republic. In this regard, the difference was more one of degree than content. Granted, Symmes spilled a lot of ink on the topic of manners and comportment, but of the two men he was probably less convinced that the boys' future status might ride comfortably atop their pedigree, and felt it was something that in his experience partly had to be learned. Both men were quixotic and careless, chasing dreams larger than managerial skills could bring to fruition. Each wound up selling land with unsecured titles as he grasped toward his personal vision of being a wealthy gentleman land magnate. And when each man failed-and each failed spectacularly-he complained that persecutory enemies were bent on robbing him of the legitimate rewards of sacrifice and hard work.

For the longest time Symmes outwardly revealed no serious hesitation upholding Short as a man to be honored and respected, and before Short's dramatic crash he reminded the boys that their ultimate respect was owed their "honored pah." At some point Symmes must have learned of the "Spanish Conspiracy," as the Wilkinson intrigue came to be called. By the time of the adultery hearing, he certainly also knew of Short's foiled attempt to steal Rachel Robards away from her husband, a fellow Virginia-born gentleman. Within a few years of Maria's marriage, Symmes had to know that Short was in financial trouble, the aftermath of his foolish connections to the slippery Wilkinson. And by 1802, when William Short finally visited the states to check on Peyton's management of their inheritance, Symmes must have heard of William's extreme displeasure at finding family assets rapidly dwindling due to Peyton's hasty

comes from William Short and is quoted in Short and Richardson, unpublished manuscript, Short Family Papers, Filson Historical Society. 
speculative ventures. Perhaps eventually Symmes knew all of these things. Outwardly, he urged the boys to respect their "honored pah," but perhaps the awareness of Short's uneven past is one more reason Symmes wrote the boys such careful instructions and watched them so wistfully from afar.

The intense affection Symmes displayed for his family, including his grandsons, compares favorably to that feature common to many planter families in the South. Thomas Jefferson, for example "idealized affectionate family life." On the other hand, Peyton Short's sons felt his relationship to them was one characterized more by distance and reserve. Parenting styles and possibly also modes of grandparenting likely varied widely. For example, Stephen Frank cautions that a "wide range of parental behavior and beliefs" characterized the nineteenth-century Northern fathers he studied. Given Symmes's movement from New England to the middle Atlantic coastal region, the salient cultural referents from which he drew to inform his own fatherhood or-more importantly-his grandfatherhood, remain unclear. No work on grandfatherhood as a separate condition appears to exist, but it seems safe to say that Symmes learned to appreciate the precious nature of family relations by being deprived of so many of them over the years. Lisa Wilson claims that colonial New England families were normally affectionate, a point that scholars sometimes miss because of the language colonists used. The two hallmarks of fatherly affection she identified in colonial New Englanders were the concern for proper behavior and education in their children, and these salient features were also foremost among the concerns Symmes expressed regarding his grandsons' development. ${ }^{84}$

Although the judge clearly had a tender and affectionate slant, those scholars who offer readers instead a grasping, quarrelsome, and self-centered

${ }^{84}$ Cynthia A, Kierner, "Martha Jefferson and the American Revolution in Virginia," in Children and Youth in a New Nation, James Marten, Ed.(New York: New York University Press, 2009)30; Stephen M. Frank, Life With Father: Parenthood and Masculinity in the Nineteenth Century (Baltimore: Johns Hopkins University Press, 1998), 2; and Wilson, Chapter Five. 
Symmes are not necessarily incorrect in their assessments. The ugly realities of an uncertain economy exacted the same toll from the most confirmed gentlemen that it demanded from everyone else. Apparently, land speculation and failure created a Symmes whose behavior ventured away from reflecting his personal ideal. As long as he believed his grandsons possessed the certainty of a secure and easy future, Symmes could promote the illusion that men of pure gentility still rose above the fray. The boys' financial crisis forced Symmes to finally verbalize the changes he already embodied, but clearly hoped would not become part of the permanent landscape confronting men in the Ohio River regions of the new republic.

To observers of Symmes, whether contemporaneous or separated by the distance of nearly two centuries, he was a man of the new nation. The texture of his life included influences from New England, the middle Atlantic, the South, and the emerging West-on both sides of the Ohio River. His was a life tied completely to no particular American region, but at the same time fastened loosely to all of them. That being the case, Symmes seemed to fit in wherever his business or civic duty took him, in civic affairs and in life. To be sure, he made enemies. Political enemies he expected; vengeful purchasers of confused land titles he thought responsible for their own problems.

In the Ohio Valley and frontier Kentucky Symmes blended fairly seamlessly into a world often populated, and sometimes dominated, by migrating Virginia planters, especially when his daughters' families are included in the mix. Somehow, Symmes managed to keep his own negative views of slave culture from creating serious rifts with associates or relatives who owned slaves. The Shorts' large Kentucky plantation was "well stocked" with slaves and even Mama Henry apparently purchased slaves after she moved to Lexington with Jane. Symmes and Harrison shared the labor shortage frustrations that were fairly common in regions in the Old Northwest, where slavery was banned by the 
Northwest Ordinance. Harrison threw his influence as Indiana Territory governor into a movement there that aimed to solve the labor shortage by circumventing the ban; indeed, Harrison and others there kept slaves—or "indentured servants," as some called them. ${ }^{85}$

For Harrison, establishing himself as a slaveholder could allow him to reclaim a social rank that had diminished some alongside the small paternal inheritance that he had promptly mismanaged. Men of his background certainly never expected to do agricultural work on their own extensive lands. Symmes, however, took some pride in his agricultural activities, although he complained of the difficulty of finding reliable and loyal help. He was among Ohio Country settlers residing north of the river who believed Kentuckians generally lacked ambition or a work ethic, characteristics Northerners often assigned to Southerners and attributed to the cultural impact of slavery. ${ }^{86}$

When Peyton Short remained absent several months after he fled Kentucky, Symmes took advantage of the parental vacuum to press the boys to plan futures on free Ohio soil, something Short might have resented, and perhaps did later. In a letter penned to Charles, Symmes wrote,

The case is already decided that you must both settle on this side of the Ohio. You cannot live in Kentucky reputably without negroes. Here you will need none. They are a curse here to the master. The lowbred whites are always conspiring with the black to rob their owner. Here a man may feed and saddle his own horse without danger of losing either his bride or his election, or may go from the bench of the Supreme Court to his woodpile, chop his wood and make his own fire without danger of having his legal judgments set aside as vulgar errors. ${ }^{87}$

\footnotetext{
85 Paul Finkelman, An Imperfect Union: slavery, Federalism, and comity (Union, New Jersey: Lawbook Exchange, Ltd, 2000), 85; Owens, 68; and Cayton, Frontier Indiana, 187-193.

86 Cayton, Frontier Indiana, 187; and Etcheson, 6-7.

87 Symmes to Charles Short, 9 April 1810, John Cleves Symmes Papers, Indiana Historical Society. Also see Bond, Intimate Letters, 39.
} 
Emboldened by family calamity, Symmes pushed the notion that free soil regions were culturally superior to the slave South. Nonetheless, he recognized the necessity to sugar-coat the labor force frustrations that dogged large landowners in a region where slaves were banned and so many potential employees could afford their own plots. Symmes defended his honor as a man who occasionally performed hard labor at the same time he asserted that the boys' path to living "reputably" was an easier one to travel in free Ohio. His plea was couched in decidedly pragmatic language, but it also hints that Symmes felt a little defensive.

Symmes normally kept a fairly low profile regarding his feelings on slavery, despite his upbringing in a family that supposedly opposed it strongly. As a territorial judge he occasionally had to rule on cases that involved illegal servitude, and in that capacity Symmes even freed two slaves brought into the region. However, family attachments and the aspiration he shared with his sonsin-law to become wealthy gentlemen land magnates kept Symmes focused on harmonious relations, although those with Harrison have been described as "cordial more than close." It took the boys' financial emergency to stir Symmes to press openly for their relocation to Ohio, but apart from a little tension between Symmes and the two uncles, family relations apparently suffered little upset as a result. $^{88}$

There was an ongoing conflict, however. It was one only Symmes and Short knew much about and the weighty significance of which was not lost on either of them. Symmes may not have paraded his attachment to his ancestral past, but as his grandsons grew older, Symmes realized how desperately he wanted them to connect in a meaningful way to the Symmes side of their heritage. It had begun with their inheritance of Symmes family land in New

${ }^{88}$ Bond, Intimate Letters, xxix-xxx; and Owens, 39. 
Jersey that had belonged to Symmes's daughter Maria before she died. When control of it went to Short, supposedly in trust for the boys, Symmes realized Short would rather sell and invest in western acreage with better prospects of producing income. For some parts of New Jersey lands Short controlled, that was fine, but Symmes hoped portions, especially those closely tied to his own early life there, would exist in future years for his descendants to visit, as well as provide college income for John.

To assure that the boys understood the importance of their northeastern roots, Symmes described for them in lengthy detail a journey about which he fantasized whereby he and the boys made a tour of those New Jersey lands for which he was so sentimental, what Symmes called "that hallowed ground." Regarding the Long Island property on which he was born Symmes pointedly exclaimed, "Hallowed spot on earth! Were it mine I would not exchange it for a kingdom." But he wished to do even more, he said. Symmes wanted to take them through New England, seeing the graves of long-dead ancestors, paying homage to their deeds and respect to their memories. Certain lands signified respect for heritage to Symmes. Toward that end, he made sure the boys had Ohio land near his own, too, hoping they might one day settle there, which John eventually did. $^{89}$

Peyton Short understood the vocabulary heritage. After all, this was a language the planter aristocracy spoke flawlessly. Bertram Wyatt-Brown cautions, however, that "some Northern families were as conscious of lineage, honor, and patriarchal authority as Southern families were." ${ }^{\text {"While Symmes }}$ certainly did not wear his ancestral consciousness as overtly as did Boston Brahmins, he was still aware that the maternal background of John and Charles

\footnotetext{
${ }^{89}$ John Cleves Symmes to Charles Short, 8 March 1809, in Bond, Intimate Letters, 29-33.

${ }^{90}$ Wyatt-Brown, 127.
} 
was quite respectable. The problem was that it really did reside, figuratively speaking, in the background. Symmes must have wearied at hearing Short's maternal relatives referred to with the titles of English nobility. With Maria gone, Symmes knew that after his own death there would be few tangible reminders that the boys had connections to something other than the Virginia and Kentucky planter aristocracy.

By leaving John and Charles a patrimony in the form of Ohio land he had purchased for each of them, Symmes hoped to set them on the way to solid futures, plant their roots on free soil in a region founded by their grandfather, and create a sense of permanency that they could pass on to their own sons. Rents produced on ancestral New Jersey lands would supplement their incomes and give them reason to go back East periodically, where Symmes expected they would be thankful the former possession of their grandfather was not to be gazed upon as outsiders, exiles from its precious memories. At least that is what Symmes insisted to Short when Peyton first talked about selling it.

Short secretly had a different idea of patrimony. Lands assigned to John and Charles as individuals pulled attention-and assets-away from the creation of the best family estate Peyton could acquire. For him, this was the true heritage, and when the time came, this is what would pass on to his sons. In keeping with planter family culture, the ambition and energy of young sons should function to preserve the family fortune and focus all honor and respect upon their father. At one point, Short complained bitterly to Symmes that Symmes expected land gifts to sons-in-law be held by them for future generations, a stipulation Symmes placed upon no others. Short marked it up to 
"jealousy," but should have realized Symmes did not want his ancestral lands or the memories they evoked leveraged to increase Peyton's personal estate. ${ }^{91}$

At the time of Peyton's meltdown, there were plenty of things about which Symmes could have been angry. Short abandoned his motherless family to uncertain circumstances, made himself impossible to contact for over a year, and put so much stress on his recently departed wife's mother-Symmes's own beloved former mother-in-law-that that she soon died, as well. However, the thing that really enraged Symmes seems rather minor by comparison-that Short had begun the sale of John's New Jersey lands. For all Symmes knew, those payments were being used to fund John's presence at Princeton that very term. But Symmes had specifically predicted to Peyton some years before that when John went to Princeton, he would be grieved to feel himself an outsider to the family lands that connected him to the Symmes lineage. And while there is no evidence that John felt so inclined-in fact, Short had challenged that presumption when Symmes made it-the point Short should have seen was that Symmes cared, and hoped when John got to New Jersey he too would learn to care. When Symmes raged that Peyton's collapse had disinherited John, he meant it in the most literal sense, that of taking away John's maternal heritage.

Just as Symmes might have predicted, Peyton Short's eventual recovery, if it can be called that, eventually came funded partly from assets that Symmes always meant to belong to the boys. As soon as John reached legal age, Short had him leverage those holdings to help develop Kentucky land Peyton was in the process of buying, another too-good-to-be-true opportunity. Of course, in the end it really was. Previously, Peyton had insisted that Symmes's assessment of him was misplaced; he would never endanger his children's inheritance.

${ }^{91}$ Wyatt-Brown, Southern Honor, 120-121; and Peyton Short to John Cleves Symmes, date uncertain, ShortSymmes-Harrison Papers, Library of Congress. That Symmes is the recipient of this letter is clear from the text. The date of the letter would be between 1794 and 1809, according to the facts contained therein. 
Moreover, he added, "We have both passed through a rigid discipline in the school of adversity. If our respective sufferings have not inspired our bosoms with a mutual sympathy, they ought at least to have taught us a lesson of charitable forbearance. ${ }^{92}$ Symmes never agreed.

In 1813 Symmes was broke, living in Cincinnati with the Harrisons, and perhaps already suffering the early symptoms of the cancer that killed him the next year. Symmes passed his days with only occasional contact from John and none from Charles, who was in school in Philadelphia. He had long since stopped sending his greetings to their "honored pah" in any letters he sent the boys-now men, actually. John had finished his legal training, but was prone to moodiness, and for a time flitted from one plan for his life to another, which alarmed Peyton, ironically. But Peyton needed John's full commitment to see to it that all their assets were leveraged toward creating for himself-he said for his whole family - a new Kentucky estate. In numerous letters on the topic, Peyton appealed to John's sense of family loyalty. One, written in early 1813, read:

You too well know the late as well as present state of my affairs for me at this time to make any comments on them. Like a once robust constitution my estate has been shocked by a most violent combination of disorders, now inflamed by the most burning fevers, and now chilled by the most freezing consumption. In short, but for the ministration of a timely restoration, ere this time it would have sunk into its grave. You may now compare it to [a] patient in a state of convalescence. Nurse it with care, and in a few years it will be restored to its pristine health. You know that you have been selected as an auxiliary nurse and physician. Perform your office with fidelity and care, and every symptom of disease will soon be removed, but neglect the patient, or mismanage the disorder, and it will in all probability return with the most fatal paroxysm, carrying death and dissolution in its course..$^{93}$

\footnotetext{
${ }^{92}$ Peyton Short to John Cleves Symmes, 20 April 1812, Short-Symmes-Harrison Papers, Library of Congress. That this letter was addressed to Symmes is evident from its contents.

${ }^{93}$ Peyton Short to John Cleves Short, 26 February 1813, Short-Symmes-Harrison Papers, Library of Congress.
} 
The boys knew only too well that Peyton could be somewhat dramatic, and John probably took that into account when he read this overdrawn metaphor of estate as the very essence of life. In other correspondence, Peyton had been blunt: John and Charles had assets that Short needed to rebuild the family plantation, which also would function down the road as a traditional inheritance for this planter's sons. However, the level of obligation placed on John to make the family estate his foremost concern is remarkable, nonetheless.

Symmes died early in 1814, and if the Short men took special notice of it that fact it is not evident in their correspondence. John and his Uncle Harrison were co-executors of Symmes's personal estate, the condition of which was so precarious that Symmes had told them to keep any money they could produce from it for their efforts. ${ }^{94}$ That year and thenceforth Peyton's sons were busy doing as he wished, leveraging various assets to provide a family plantation and rebuild Short's landed legacy in Kentucky. John's law training came in handy when it came time to oversee legal transactions. The New Jersey lands passed into the hands of people who had no special connection to its past. Some of the Ohio lands helped fund activities relating to lives Peyton and Charles created elsewhere. There is no evidence the boys ever took the excursion their grandfather dreamed for them and paid homage to their northeastern forbears.

Mark Kann writes that the traditional American patriarch of the lateeighteenth century viewed marriage partly as a vehicle by which to produce legitimate sons and "continue his 'accomplishments, indeed his very character, into the future'." One such man, he notes, claimed that "grandfathers often were 'more affectionate towards their children's children than to their immediates as seeing themselves further propagated in them, and by their means proceeding to a further degree of eternity, which all desire naturally, if not in themselves, yet in

94William Henry Harrison to James Henry, 4 March 1814, William Henry Harrison Papers, Indiana Historical Society. 
their posterity'." Kann adds that the "concerned father. . . expected to achieve a sense of immortality through his children." Without sons of his own, Symmes apparently transferred that expectation onto grandsons John and Charles. If, as Kann also claims, Southern men desired to "extend family dynasties" much longer than the one generation typical of Northerners, then in promoting a long view of his northeastern heritage for the boys' memory, Symmes may have actually been adapting to Southern cultural influences. ${ }^{95}$

${ }^{95}$ Mark E. Kann, A Republic of Men: The American Founders, Gendered Language, and Patriarchal Politics (New York: New York University Press, 1998), 7. 
CHAPTER 2: JOSHUA GIDDINGS: AMBITION, MENTORSHIP, AND THE CIVIC VOICE

In 1839, the opponents of freedom went too far. The Kentucky General Assembly, responding to complaints of slave-owning citizens tired of chasing "property" escaped to Ohio, insisted that the Ohio legislature help solve the problem. The result was Ohio's comprehensive fugitive slave law of 1839. Not only did the new code fairly invite the kidnapping of blacks - whether former slaves or not-but it made interference with recapture a crime and placed "special restrictions" on three or more persons assembling who might "cause a disturbance." "Infuriated" Ohio abolitionists called for the defense of blacks, defiance of the law, and reclamation of republican ideals. ${ }^{1}$

Joshua Giddings, freshman United States congressman from Ohio, was already angry: the federal government was aiding in illegal slave recaptures in Florida Territory in the "piratical" Seminole War. In an Ohio ambiance of obstructionism and fed up with government abuse, Giddings joined local friends to create an organization of resistance, albeit one aimed primarily at the national misdeeds that demanded most of his attention. Giddings wrote its constitution, which reads, in part:

Whereas the authority of Britain over her American provinces was first set at defiance by an association of patriots called "the Sons of Liberty," who by their personal efforts concentrated their influence, and gave direction to the popular voice which is always powerful when guided by discretion and judgment ... we hereby revive the ancient order of "the Sons of Liberty" . . . to inculcate and maintain the duty of human governments to protect human rights; that the violation of those rights by officers or by men acting as a government constitutes a crime... [and] we declare that "no person shall be

\footnotetext{
${ }^{1}$ Stephen Middleton, The Black Laws: Race and the Legal Process in Early Ohio (Athens, OH: Ohio University Press, 2005), 174-175.
} 
deprived of life, liberty, or property without due process of law" where we have power to prevent it. ${ }^{2}$

The Revolutionary rhetoric of rights and liberties was part of the common culture in the early republic. In fact, men such as Giddings's father had witnessed the halting transformation in status from British "subjects" to American "citizens." Founding documents did not close debate on what would be the rights and privileges of citizenship, however, nor did colonial holdovers in customs or institutions immediately give way. On the contrary, in the decades following the Revolution, Americans worked out ideas about civic equality, the role of law in contests for power and justice, and the "legitimacy of organized power." ${ }^{3}$

Giddings and his fellow "Sons" believed a civic crisis threatened when government began violating the very rights it existed to protect. Even from Washington, Giddings's instinct was to reach back to Ohio-to his base of masculine identity, cooperation, and influence. Giddings promoted returning to what he understood as the essence of American citizenship. His description of it is remarkably similar to one scholars still use: a bloc of "free people who collectively, possess sovereignty. "For Giddings, the preferred vehicle for this expression was ultimately politics - not only as it relates to the general distribution of power in society, but also how that power is funneled through organizations formed specifically to express the "popular voice."

2 "Constitution of the Sons of Liberty," Vertical File Material (Giddings, Joshua Reed), WRHS. This document is in Giddings's handwriting and a notation added afterward confirms the authorship. Approximation of the date comes from comparing comments in the text with known historical events and Giddings's other writings. Clandestine Sons of Liberty clubs also appeared in Giddings's home region after John Brown's capture in 1859. Some locals pledged themselves to prevent federal apprehension of Brown's family members living in the area. See William O. Williams, History of Ashtabula County, Ohio (Philadelphia:William O. Williams, 1878), 35 (transcript accessed online at http://solomonspalding.com/SRP/saga2/1878Ast1.htm).

${ }^{3}$ Douglas Bradburn, The Citizenship Revolution: Politics and the Creation of the American Union, 1774-1804 (Charlottesville, VA: University of Virginia Press, 2009), Introduction.

${ }^{4}$ I have used the same definition Bradburn uses. He credits David Ramsay, A Dissertation on the Manner of Acquiring the character and privileges of a citizen of the United States (Philadelphia, 1789). 
In reality, men who envisioned themselves as society's leaders-both shaping and expressing the popular will-learned that to "concentrate their influence and give direction to the popular voice," as Giddings wrote, they must prove themselves worthy to "guide by discretion and judgment." That accomplished, these men still had to constantly renegotiate their alliances and terms of cooperation, or risk diluting their influence. Joshua Giddings, New England migrant to frontier Ohio, was one of those men. This chapter examines how he managed to identify that voice in himself, prove its legitimacy, and join it to those of other civic-minded regional men to increase its effectiveness. Along the way he also served his own ambition, managed personal loyalties, and weathered the crises that Antimasonry, religious awakening, financial panic, and antislavery discord represented to his circle of close associates, threatening their ability to cohere and to lead.

Central to that process in Giddings was his relationship to professional and political mentor, Elisha Whittlesey. Whittlesey's figure cast a long shadow during this period of Giddings's life-roughly 1820 to 1840 . Even those aspects existing mainly apart from Whittlesey, such as revivalism, antislavery activism, or Giddings's battle with chronic depressive illness, existed alongside everyone's awareness that Giddings's remarkable rise and probably his political future both linked inextricably to Congressman Whittlesey. As Giddings leveraged that connection and crafted a significant role for himself on the Reserve, he associated with an acknowledged pool of leading men, becoming close to a handful of them, including Whittlesey. A series of turbulent events in the 1830s tested those relationships and challenged Giddings's own attempt to become a professional and political mentor. Through it all, he remained aware that every crisis threatened not only to disrupt the ability of his Reserve cohort to negotiate a coherent civic voice, but also to diminish his own standing as one they trusted to help shape it. 


\section{The Rise}

Giddings grew up in hardship and he knew it. His birth in 1795 completed a large family that included several half-siblings, some of whom were substantially older. His father-also named Joshua-had just ushered the family out of Connecticut, and young Joshua spent nearly the entirety of his first decade in Canandaigua County, New York. The family—including one son-in-law-struck out again for the Connecticut Western Reserve lands in Ohio. Similar to most Reserve settlers, they had begun their westward migration from rural Connecticut seeking fertile, affordable farm acreage as they concomitantly fled an unstable local economy. The crude homestead they hastily constructed there in Ashtabula County was ten-year-old Joshua's third. ${ }^{5}$

Undergoing a rush of Eastern migrants, northern Ohio was still a challenging environment, blanketed by dense forests and muddy soil. The Western Reserve comprised the northeastern corner of Ohio and originally existed as an intended western extension for Connecticut. At this time, fear of Indian uprisings in the western portion of the Reserve led newcomers to concentrate their homesteads in the eastern half. Settled primarily by families from Connecticut and Massachusetts - often by way of upstate New York-the region quickly became distinguished in Ohio for the distinctly rural New England quality of its villages,

\footnotetext{
${ }^{5}$ The standard biography on the life of Joshua Giddings is James Brewer Stewart, Joshua R. Giddings and the Tactics of Radical Politics (Cleveland: Case Western Reserve University, 1970). Also useful is George Washington Julian, The Life of Joshua R. Giddings (Chicago: A. C. McClurg and Company, 1892). Of interest, if extremely brief, is Walter Buell, Joshua R. Giddings: A Sketch (Cleveland: William W. Williams, 1882). An especially revealing glimpse into several early events in Giddings's life exists in an unattributed biography fragment housed with the George W. Julian collection in the Indiana State Library. It remains unclear exactly who penned the short essay titled "Biography of J. R. Giddings," but the level of detail it contains leaves little doubt that the information must have been dictated by Giddings at some point. The text does not resemble that of the biography later published by son-in-law George W. Julian. More likely, the author is one of Giddings's two daughters - one of whom was Julian's wife - as material from both women appears in the Julian collection. Unfortunately, if the essay was ever completed relating to years beyond 1822, that portion apparently no longer exists.
} 
society, and political culture. Consequently, the men who tackled the landscape and built its institutions and towns shared bonds forged through this unique and defining experience. ${ }^{6}$

One such man was Giddings's father. A very religious man, this migrant carried among his valued belongings a letter of recommendation from his old Congregational church. Clearly, he meant to re-establish fellowship wherever he settled, and embraced church membership as a component of character. In fact, despite the absence of clergy, the elder Giddings hosted one of the earliest religious gatherings on the Reserve in his cabin.

That faith was painfully challenged several years later when the title to his land proved faulty. Improvements and labor all for naught, the Giddings troop suddenly found themselves homeless and penniless. Any expectations that father Joshua could provide land for young Joshua, then 14, must have quickly faded. The family struggled to regain a foot-hold, hoping eventually to purchase land for themselves again. ${ }^{8}$

In the meantime, a season of scarce provisions led Giddings's father to hire him out to a wealthy Reserve farmer-one month of field labor for enough wheat to keep the family in bread. As the outright owner of substantial property, employer John Andrews was recognized as belonging to the first rank of Reserve men, and his situation presented a stark contrast to the struggling Giddings family venture.

\footnotetext{
${ }^{6}$ Stewart H. Holbrook, The Yankee Exodus: An Account of Migration from New England (New York: MacMillan, 1950). See especially Chapter Three. The best general history of the Western Reserve remains Harlan Hatcher, The Western Reserve: The Story of New Connecticut in Ohio (Kent, OH: Kent State University Press, 1991).

${ }^{7}$ Aaron Church to "the Church of Christ," 21 January 1799, George W. Julian Papers, Indiana State Library (hereafter, ISL). Aaron Church served as pastor to Giddings's church in Hartland, CT. On worship in Giddings's cabin, see William O. Williams, History of Ashtabula County, Ohio (Philadelphia: Williams Brothers, 1878), 72-84 and 243.

${ }^{8}$ Stewart, 5; and Julian, 19.
} 
Andrews was an educated man and kind employer; days hastened as he and Giddings labored together, absorbed in discussion. Recognizing Giddings's potential, he offered his patronage in support of his young charge's future career path. Much later, Giddings rebutted critics of northern free labor by referring them to his employment by Andrews, to whom he said he had felt equal, despite their relative extremes of wealth. Of course what he omitted from that story was the bare fact that it was because Andrews agreed to it in theory and in practice that it existed at all. Nonetheless, it did great things for Giddings's self confidence that the two became lifelong friends. ${ }^{\text {? }}$

Giddings imbibed early the lesson that some kinds of status were not dependent upon wealth. Embarrassing as it must have been to see his aging father thrown into poverty, he knew that same father had always played an active role in civic life. In Ohio, Joshua the younger observed his father, older brothers, and brother-in-law aid in the creation of a new civic environment, where they occasionally functioned as election or town council officers. Usually, this was more easily accomplished in townships where a wealthy family with especially large holdings had not asserted early dominance in town affairs. Nonetheless, at this stage of development men on the Reserve generally accepted that decent character and leadership potential qualified even struggling men to join the debate over how to understand their obligations and duties in relation to each other-and the country.

The men in Giddings's family rose fairly quickly to minor leadership roles, perhaps in part because they were not entire strangers to everyone on the Reserve. Frequently, Reserve inhabitants knew each other because they had become acquainted back East. In fact, often dozens of inhabitants of a New

\footnotetext{
${ }^{9}$ Author unknown, "Biography of J. R. Giddings" (undated documentary fragment), George W. Julian Papers, ISL. Years later, when Giddings was fighting slavery from Congress, Anderson reportedly read of the salutary effect Giddings claimed Andrews's kindness had on his sense of self-worth, and was brought to tears.
} 
England town migrated en masse, just as happened in Hartford, Connecticut, the Giddingses' hometown. Relatives of father Giddings's first wife, Submit Jones, also settled on the Reserve. In fact, young Joshua's brother-in-law, Nathaniel Coleman, was somehow related as well to this same Jones clan. It appears other Giddingses-perhaps distantly related-settled in the general area, too. As a lawyer, Coleman may have seemed a natural choice for civic leadership, but in this environment, character and ability were sometimes recognizable even in men whose immediate situation might suggest otherwise. In a sense, then, men could transport a family reputation for civil and religious responsibility with them, along with a supportive network of neighbors and kin. ${ }^{10}$

One civic duty expected of Reserve men was military service. The call came early in the War of 1812 to the Giddings household. Indians across northern Ohio had allied with British interests; confrontations were expected. Giddings-still underage-offered to serve in place of his brother, whose contribution to their support the family loathed to spare. ${ }^{11}$

Neither soldiering nor farming really appealed to Giddings, however, who soon announced his intention to study law. Pious neighbors warned him against tempting God's will by aspiring to rise above his assigned humble station in life. A man of his background could not succeed as a lawyer, anyway, some associates warned, but by the time of his certain failure he would have lost his "love of labor," and thus be without either means of support. However, these warnings revealed to all sides that Giddings's goal was understood as more than attaining a means of support. Giddings's critics had accepted their stations in life, and questioned why

${ }^{10}$ On the extended Jones clan, into which the sister of Joshua Giddings's wife also married, see L. Newton Parker, History and Genealogy of the Ancestors and Descendants of Captain Israel Jones of Barkhamsted, Connecticut (Prepared for Hon. Asahel Wellington Jones, 1902). On the civic involvement of Giddings and Jones men, see Moina W. Large, History of Ashtabula County, Ohio (Topeka: Historical Publishing Company, 1924), Chapter Twenty-Three, accessed at http://www.conneautohio.us/Ashtaco ConneautHistory xxxviii.htm.

${ }^{11}$ Author unknown, "Biography of J. R. Giddings" (documentary fragment, n.d.), George W. Julian Papers, ISL. 
this youngest son of a poor farmer could not be grateful for what appeared to be his natural destiny. The unspoken message-for some, the fear-was that Giddings's ambitions would change their relative status, even if the courier couched it in the language of Christian obedience. ${ }^{12}$

Such strict religious determinism and Federalist New England codes of deference were rapidly waning on the Reserve, however. Instead, Giddings came to share the religious and reform interests of New England's mainstream evangelicals, whose ideological currents traveled the same paths across New York and into this northeastern corner of Ohio as the migrants who continued to settle there. Unlike his Puritan forbears, Giddings rejected religious establishment and Calvinistic orthodoxy in favor of the liberalizing and democratizing trends sweeping across the North as part of the Second Great Awakening. A revised "New School" Calvinism allowed man more responsibility for his salvation, as did the controversial "new measures" of the revivalists. Deference to tradition and community eroded before a rising culture of individualism. ${ }^{13}$

Moreover, due to recent changes in production modes, young men increasingly pursued their own goals, no longer dependent upon their fathers to provide a livelihood, as had been the pattern in rural New England. Fathers found it increasingly difficult to provide land or arrange occupations, so quite often other willing men stepped into the breach. This was fine with young Giddings. Unceasingly curious and driven by ambition, he rejected his father's precarious agrarian example and entrusted Elisha Whittlesey to chart him a path to success. In an era when the viability of pure patriarchy was waning, young men attached

\footnotetext{
${ }^{12}$ Julian, 21; and Author unknown, "Biography of J. R. Giddings" (documentary fragment, n.d.), George W. Julian Papers, ISL.

${ }^{13}$ Irving H. Bartlett, The American Mind in the Mid-Nineteenth Century, 2 ed. (Wheeling, IL: Harlan Davidson, Inc., 1982) 42-43.
} 
great significance to pleasing masters or mentors-a source outside fathers for possible aid in launching young man's career. ${ }^{14}$

As one of the Reserve's most admired citizens, Whittlesey provided an excellent role model for a young man hoping to attain social and professional prestige. He had also arrived with some of the Reserve's earliest settlers, newly married and with a fresh Connecticut law degree. Polly Whittlesey's well-to-do parents joined them in Canfield, Trumbull County, only one year later. Whittlesey promptly allied himself there with wealthy and influential men, one of whom was land magnate Simon Perkins, who became Whittlesey's mentor. Whittlesey was a "leading spirit" in local fraternal organizations, such as the Freemasons and the purely social "Onion Society." Before long, Canfield folks were greeting their town's principal attorney as "Squire Whittlesey." Whittlesey's name became associated with the establishment of the Reserve's first (and largest) bank, as well as the building of churches and schools that show a community is thriving. In fact, Canfield soon gained a reputation for being a desirable village, due in part to the quality of people it attracted. Whittlesey served in the War of 1812 in the Fourth Militia Brigade, which encompassed the Reserve, and rose-under General Simon Perkins's leadership_to Brigade-Major and Inspector. There is no evidence that either man noticed the scraggly, underage soldier sent to represent the struggling Giddings family, toting the "old family gun." Ultimately, their paths crossed, however, and before Giddings departed his tutelage in 1820, Whittlesey had begun serving his first term as state representative in Columbus, aided by Perkins's shepherding. Elected to Washington three years later, Whittlesey served

${ }^{14}$ E. Anthony Rotundo, American Manhood: Transformations in Masculinity from the Revolution to the Modern Era (New York: Basic Books, 1993), 294; Anne S. Lombard, Making Manhood: Growing Up Male in Colonial New England (Cambridge, MA: Harvard University Press, 2003), Chapter Three; and Lisa Wilson, Ye Heart of a Man: The Domestic Life of Men in Colonial New England (New Haven: Yale University Press, 1999), Chapter Five; and Karen Halttunen, Confidence Men and Painted Women: A Study of Middle-Class Culture in America, 1830-1870 (New Haven: Yale University Press, 1982, 12. Giddings's relationship with Elisha Whittlesey receives some coverage in Stewart, Chapter One. One changes in patriarchal roles, see Anne S. Lombard, Making Manhood: Growing Up Male in Colonial New England (Cambridge, Massachusetts: Harvard University Press, 2003), Chapter Three. 
fifteen years in the House. For young men on the Reserve eager to rise, gaining Squire Whittlesey's mentorship was a superb first step. ${ }^{15}$

Reserve inhabitants did not universally approve Giddings's acceptance into Whittlesey's training program. The practice of law was normally reserved for young men with social connections and formal preparatory education. Twentythree-year-old Giddings had neither. Young Joshua's few weeks of formal schooling ended before the family arrived in Ohio. Between backbreaking days of clearing forested land for homesteading relatives, he fed his limitless curiosity with books borrowed from frontier neighbors. After his military stint, Giddings boarded for several months in Vernon in Trumbull County, where local pastor Harvey Coe tutored young men in mathematics, Latin, and-in the case of potential ministers-theology. Real encouragement came, however, from Giddings's brother-in-law and another lawyer neighbor, as well as Andrews. These men also proffered financial assistance when needed, as did Giddings's older brothers. With fathers less likely to entirely provide career launches, young men relied increasingly on other, more established men. So in early winter, 1818, though they had the barest knowledge of each other, a determined Giddings departed his home on foot for Whittlesey's Canfield office forty miles distant, eager to embark on a professional career. ${ }^{16}$

Young men hoping to enter the legal profession typically apprenticed with established lawyers, usually boarding in their homes or nearby, such as the local hotel where Giddings rented lodging. Whittlesey gained a reputation as an assiduous legal educator, training many of Ohio's outstanding adjudicators in the

15 Kenneth Edwin Davison, “Forgotten Ohioan: Elisha Whittlesey, 1783-1863," (Ph.D. diss., Western reserve University, 1953), Chapter Three. This work remains the standard comprehensive treatment of Whittlesey's life. An unnamed biographer claims Giddings went to the War of 1812 with the "old family gun" that had been the family's security from potential conflict with nearby Indians. Author unknown, "Biography of J. R. Giddings" (undated documentary fragment), George W. Julian Papers, ISL.

${ }^{16}$ Stewart, Joshua R. Giddings, 5-7; Julian, 11-22; and Buell, 9-25. 
early decades of the nineteenth century. Grooming suitable young men for potential leadership roles in law or politics fit well with Whittlesey's New Englandderived Federalists leanings. As an influential early citizen of the Reserve, he also provided his students with valuable social and legal contacts. ${ }^{17}$

The barely educated son of a failed farmer was an unlikely candidate for acceptance to legal training in the early nineteenth century. More typical was the other student under Whittlesey's tutelage at that time--Whittlesey's Yaleeducated nephew, William, from a respected eastern family. Law was a distinct profession that held a powerful place in the new republic, and the potential for shared conviviality was a primary concern among its practitioners. Frontier attorneys usually rode the legal circuit with the judge. The men traveled, ate, and lived together for extended periods. At each town, they divided the cases among them, and alongside a fascinated local audience, intently followed the ensuing extemporaneous debates that filled the day's legal docket. After hours, they enacted mock trials for any of their fellows whose actions that day deserved good-natured scrutiny. Such intense sociability led to an "alternating rhythm of competition and kinship." According to Giddings's earliest biographers, developing legal life on the Western Reserve mirrored this general pattern. ${ }^{18}$

The student culture in Whittlesey's law office developed similar characteristics while Giddings and William Whittlesey completed the two years of preparation Ohio law required prior to applying for examination. At first, the eloquent Yale graduate and halting farm-boy kept distance. The turning point in their relationship came when they debated each other at the local young men's lyceum, to which they both belonged. This valued source of popular

\footnotetext{
17 Davison, 40-41 and 109-111.

18 Julian, 23 and 28-29; Rotundo, 198; Michael Grossberg, "Institutionalizing Masculinity: The Law as a Masculine Profession," in Meanings for Manhood: Constructions of Masculinity in Victorian America, ed. Mark C. Carnes and Clyde Griffen (Chicago: University of Chicago Press, 1990), 134-137; and Buell, 26-30.
} 
entertainment attracted a substantial audience. The erudition and eloquence of William's introductory presentation invited murmurings: should this apparently cruel mismatch be allowed to continue? With scant formal schooling, Giddings lacked those valuable public speaking abilities many young men developed during yearly academy exercises. Giddings knew his oratorical skills were no match for what he had just heard, so he turned his humble background to his advantage. He apologized up front for lacking polish, but asked onlookers to allow him to state as best he could the logic and the facts of his position, letting truth be the goal. When he finished, the audience rose in applause, much to Giddings's surprise. ${ }^{19}$

Giddings suddenly realized that this was how a disadvantaged country lad could still craft an enviable reputation for himself-with self-deprecating charm and appeals to basic and sound reasoning, added of course to the thorough and methodical background preparation that characterized Giddings's engagement with any project. It was a formula he used successfully the rest of his life. Possibly the wisest thing he did that night, however, was confess to the audience how impressed he was with his opponent's oratorical abilities, noting, in fact, that no one present could be prouder of William Whittlesey than was Giddings! This cemented Giddings in his Canfield neighbors' favor, and gained him a steady friend in young Whittlesey. ${ }^{20}$

Insistence on speaking well of other men was a code Giddings generally followed, and he violated it only when he felt maliciously provoked or that some vital truth was being assailed. Unpleasant facts about men with whom he might need to cooperate someday Giddings simply never mentioned. This outward goodwill toward other men tended to make him popular, and sometimes even his

\footnotetext{
${ }^{19}$ Author unknown, "Biography of J. R. Giddings" (undated documentary fragment), George W. Julian Papers, ISL.

${ }^{20}$ Ibid.
} 
political enemies grudgingly admitted to liking him. Moreover, it signaled to the community of respectable men that under normal circumstances his strategy for elevating his reputation did not involve diminishing —or directly competing withthe reputations of others. He would not attempt to dent most other men's shields of respectability, and hoped in return they would also leave his similarly undamaged.

It appears Canfield society fully welcomed Giddings, a fact that may have originally surprised him, given the village's reputation for settlement by some of the "better" eastern families. When he wasn't studying, Giddings accepted invitations to numerous parties or dinners. He also attended the premiere male social gathering in Canfield-the Onion Society-where he happily feasted shoulder-to-shoulder with some of the region's most influential men. In Canfield, he associated socially with the same kind of men among whom he hoped someday to be numbered, and their friendship and social example could not have been more valuable, given his plans to join the legal community. ${ }^{21}$

Boundaries formed within the inchoate professional legal culture based on the acceptance or rejection of peers. Consequently, the bar tightly controlled access to its membership, so when Whittlesey requested permission for both students to take their examinations, objections arose based on Giddings's unsuitability to associate with other lawyers. Two particularly aristocratic members objected not only to Giddings's scant preparatory education, but the "sphere" in which he "moved." Despite his own ease operating within elite Reserve circles, this struck a familiar chord with Whittlesey. Newly licensed in Connecticut fifteen years earlier, country-bred Whittlesey feared he could never match the eloquence or skill of Connecticut's many talented lawyers. He once confessed, ${ }^{21}$ History of Trumbull and Mahoning County Vol. 2, ed. H. Z. Williams and Bro., (Cleveland: H. Z. Williams and
Bro., 1882), 29 . 
I thought if I remained in Connecticut ... . I could not hope to attain their height, nor to resist their strength. My reasoning was that an honest young man, with good habits, in morals, and industry, with good practical common sense, without a diploma, might make a living in a new country and be respected. ${ }^{22}$

Consequently, Whittlesey had fled to the frontier to escape Eastern snobbery and intense professional competition. Now he stood resolutely by his beleaguered young candidate, insisting that the examination go forward.

Despite a tradition for rendering only unanimous decisions, the bulk of the bar agreed to certify Giddings for examination without the approval of the two objectors. Whittlesey revealed the true nature of the objections to Giddings only after the he passed his examination, softening their potential insult by claiming they may have been politically motivated. Nonetheless, Giddings knew that despite his attainments in life, some men would always see him as the undereducated son of an impoverished farmer. On the other hand, he also understood the value of having the patronage of one of Ohio's most distinguished lawyers, and for the time being concentrated on leveraging that connection. ${ }^{23}$

Whittlesey had not only accepted the unlikely student and later defended his suitability before the bar. During Giddings's second year of study, Whittlesey allowed him to contract business in his preceptor's eminent name and keep the income thus generated, a favor that the recently-married Giddings must have certainly appreciated. Shortly after his certification, the young attorney wrote the elder man indicating that his recent assistance had placed Giddings "under increased obligation" that would "not soon be forgotten." "[N]othing," Giddings wrote later, which I shall ever have in my power to do for you will one half repay

\footnotetext{
${ }^{22}$ Quoted in Davison, 14.

${ }^{23}$ Author unknown, "Biography of J. R. Giddings" (undated documentary fragment), George W. Julian Papers, ISL; and Elisha Whittlesey to Joshua Giddings, 9 January 1821, Giddings Papers, Maag; and Julian, 23-24.
} 
the obligations under which you have laid me by your often repeated kindnesses, and should I forget them, then surely I do not possess the heart which I always flattered myself I had. ${ }^{24}$

Whittlesey knew that Giddings's feelings of intense obligation came with good reason, for not only had he allowed Giddings to earn income during his apprenticeship, he allowed him to marry before finishing the arrangement-a highly unusual occurrence. However, Giddings's sweetheart was pregnant. Moreover, when the baby arrived little more than three months after they wed, it must have entered the "town talk" that typically circulated regarding such affairs. Traditionally, New England men had talked of sexual and social affairs as a means of assessing and maintaining each man's potential in-group status. Conditions on the early Western Reserve appeared little changed; connections were still often based on trust and a circle of friends could be vital to managing the reputation of any man who had become the topic of town gossip. ${ }^{25}$

Complicating the unfortunate pregnancy's possible effect on Giddings's application to join the regional bar, his new wife's background was no more socially appealing than was his own. From a poor family of New England migrants herself, Laura Waters had been teaching school to earn her support since age fourteen. Despite the fact that premarital pregnancy rates had risen substantially in rural New England in the late eighteenth century concurrent with

24 Julian, 23-24; Joshua Giddings to Elisha Whittlesey, 29 January 1821 and 27 August 1830, Elisha Whittlesey Papers, WRHS.

${ }^{25}$ Information on Laura Waters's premarital pregnancy is ascertained by comparing her marriage date with the birth date of her first child-only three and one half months later. See Edmund West, Comp., Family Data Collection - Marriages [database online] (Provo, UT: The Generations Network, Inc., 2001). Accessed via Ancestry.com (subscription required). On "town talk" and the managing of men's reputations through circles of peers, see Thomas A. Foster, Sex and the Eighteenth-Century Man: Massachusetts and the History of Sexuality in America (Boston: Beacon Press, 2006), 79-97. 
waning parental oversight, by the nineteenth century such occurrences were increasingly associated with society's lower ranks. ${ }^{26}$

Perhaps more importantly, impregnating his sweetheart could complicate Giddings's budding career, even though a marriage eventually followed. A man aspiring to a professional occupation and community leadership could not afford to send the message that he was undisciplined or lacked sexual restraint. Furthermore, Giddings was not financially secure enough on his own to offer marriage, so self-mastery was especially important in his case. Perhaps a man with an established place in society could recover from a temporary loss of sexual self-mastery, but for a young man of doubtful background hoping to demonstrate his capacity to join the ranks of community leaders, a foolishly-timed pregnancy could place his future status in doubt. ${ }^{27}$

${ }^{26}$ Reliable information on attitudes toward unwed pregnancy in the early republic is rather scarce (although anecdotal evidence suggests social unease could accompany such events, as some families apparently altered the claimed birth date of a child conceived before marriage). Giddings's biographers are consistently vague on the details and chronology of this period. George W. Julian, who married the younger Giddings daughter, only joined the family the year before the deaths of Giddings and his wife, but obviously became aware of the potential of the untimely marriage to strain the family narrative, as he also glosses over the exact timing of the marriage and the details surrounding it. Writing after the deaths of Joshua and Laura Waters Giddings, and of his own wife, Laura Ann Giddings Julian, Julian's defensiveness on behalf of the family is still palpable. He claims a necessity to defend young Joshua's marriage to "likewise poor" Laura Waters because of his having neither the training or means to take on such responsibilities, even as he discourages further contemplation on the part of the reader: "While yet a student, Giddings was married to ... a young woman of more than common intelligence and worth .... To the eye of worldly prudence the wisdom of his marriage at this time would have seemed at least debatable .... But their marriage was the special concern of nobody but themselves, and the sequel vindicated their action." Julian, 24-25. See also John D'Emilio and Estelle B. Freedman, Intimate Matters: A History of Sexuality in America, 2 Ed. (Chicago: University of Chicago Press, 1998), Chapters Two and Three; Peter Laslett, Illicit Love in Earlier Generations: Essays in Historical Sociology (Cambridge: Cambridge University Press, 1980), 110 and 128-130; and Daniel Scott Smith, "The Long Cycle in American Illegitimacy and Prenuptial Pregnancy," in Bastardy and is Comparative History: Studies in the History of Illegitimacy and Marital Non-conformism, Peter Laslett, Ed. (Cambridge, MA: Harvard University Press, 1980), 362-378.

${ }^{27}$ Thomas, Sex and the Eighteenth-Century Man, best examines the potential social ramifications of sexual behavior for men of New England origin. Attitudes on the developing Western Reserve of 1820 would likely have come closer to resembling those of rural New England in the late eighteenth century than the cultural norms that came to embody Victorian America as the century progressed. Also see D'Emilio and Freedman, Intimate Matters. 
Giddings faced a conundrum. Likely, intense social pressure existed to marry his pregnant sweetheart. This would be the only way to secure both reputations from further damage. On the other hand, Giddings could not afford to anger Whittlesey, who could have easily justified ending an arrangement which did not readily admit Giddings's new situation. How would Giddings support this new family without means or occupation? What about the men who had invested in Giddings's future success? Was their investment to come back squandered, and what would such an outcome mean for Giddings's ability to restore a reputation thus sullied among the very men who had constituted his strongest supporters? However he puzzled his way through the dilemma that confronted him, Giddings knew his situation was precarious.

It is difficult to know with much certainty the social impact of Giddings's abrupt marriage not even halfway through his apprenticeship-and the birth of his child only a few months later. Certainly, as the Victorian era progressed, with its idealizations of female purity and morality as well as masculine financial responsibility and self-control, an untimely pregnancy or marriage could complicate identification with respectable status. It is unknown whether Whittlesey laid more responsibility for this unfortunate complication of Giddings's legal training on Joshua or Laura, or whether Giddings knew Whittlesey's thoughts on it. Giddings had to know that it was highly irregular for a boarding legal apprentice still early in his program to marry, and that Whittlesesy was under no obligation to accommodate this abrupt change to Giddings's situation, much less allow him to begin to earn income from cases initiated in Whittlesey's name (although Whittlesey apparently allowed his nephew to do the same). It is not clear where Giddings resided to complete his training, or whether the couple even lived together, but by the time Giddings finished his training and set up his own practice forty miles north in Ashtabula County, the couple was housekeeping there on the family farm. Fortunately, Laura Waters had invested some of her teaching pay in a 
flock of sheep, the sale of which brought enough profit to purchase Giddings's initial law books, and begin practice independent of Whittlesey. ${ }^{28}$

The issue of Giddings's acceptability to associate with members of the bar was still far from resolved in the minds of the region's self-appointed aristocrats who had opposed allowing Giddings to take his examination. Shortly after gaining his license, Giddings unknowingly found himself opposite one of them in court. This opponent was Roger Griswold, son of an elite Reserve founder. During the trial, Griswold compared notes with the son of Gideon Granger, another elite founder and Reserve magnate; it would not do to suffer defeat at the hands of such a man as Giddings. At one point, the elder Granger had owned much of the county in which Giddings now lived. Reserve inhabitants considered these two scions of Reserve aristocrats among the region's best- educated lawyers. When the judge, similarly dubious of Giddings's acceptability, upheld them in court, riveted onlookers agreed that these two lawyers and the judge had proven the superiority of their backgrounds and education in what must now be an ironclad case. ${ }^{29}$

Giddings, however, was not so sure. He appealed the case to the state supreme court, where it was overturned. So embittered was the judge at receiving his comeuppance at the hands of an aspirant like Giddings that in the years following he ruled against Giddings every chance he got. Rankling as he did at implications of inferiority, Giddings let no personal slight go unchallenged, but wisely tempered his parries with as much good-natured humor as his responsibility to clients allowed, thereby lightening the entire courtroom environment. Eventually, the judge grew to take his prejudices against Giddings

\footnotetext{
${ }^{28}$ Harriet Taylor Upton, History of the Western Reserve Vol. 1 (Chicago: Lewis Publishing, 1910), 567.

${ }^{29}$ Author unknown, "Biography of J. R. Giddings" (undated documentary fragment), George W. Julian Papers, ISL. The Griswolds were notoriously aristocratic, and some from that family felt Whittlesey rose too high, all things considered. See Joshua Giddings to Elisha Whittlesey, 27 August 1830, Elisha Whittlesey Papers, WRHS.
} 
less seriously, and he gradually accepted Giddings as a legitimate colleague. Reserve inhabitants, become wary of hiring a new lawyer so obviously despised by the local magistrate, finally came around, as well. ${ }^{30}$

So here was a formula for success that seemed to be working well for Joshua Giddings: praise other men's abilities, good-naturedly disarm your opponents (befriend them if appropriate), and make every connection work to your potential benefit. When Elisha Whittlesey "stood"-politicians hated to admit to actually seeking anything-for election to the United States Congress in 1822, Whittlesey and his friends recognized the potential usefulness of Giddings's gregarious nature, drive, and charm. Whittlesey's election opponent made his living as a substantial farmer, and as such, did not invite the anti-lawyer prejudice that was strong at the time among a number of the Reserve's primarily rural inhabitants. Sensing potential defeat, Whittlesey asked Giddings to talk to certain men in Giddings's home of Ashtabula County, where support for Whittlesey was questionable. Giddings not only did so, but sent Whittlesey a long, detailed report of all his activities there on Whittlesey's behalf. Some of Whittlesey's friendsbelieving "success was doubtful"-also wrote Giddings and "earnestly suggested" that he do all he could to sway the county's leading men toward Whittlesey. Apparently, they had all determined to support Whittlesey's opponent, despite the former's superior qualifications. Giddings assured Whittlesey of his discretion, noting that the only man to whom he had revealed the full scope of his mission was his brother-in-law, Lynds Jones. Not only would Jones "not expose them," he had also promised to gather what useful information he could as he made rounds in the county on professional business. ${ }^{31}$

Here the narrative diverges, however, apparently depending on the circumstances under which Giddings was revealing the event. An unpublished

${ }^{30}$ Ibid.

${ }^{31}$ Ibid.; and Joshua Giddings to Elisha Whittlesey, 22 August 1822, Elisha Whittlesey Papers, WRHS. 
family memoir emphasizes the fact that on election night, with all county totals reported except Ashtabula, a dejected Whittlesey retired to his home, certain of defeat. Shortly after, he sullenly entertained a call from the apparent victor, come to gloat. Almost immediately, however, a courier brought news of a shocking reversal of fortune. Ashtabula County voters had gone almost unanimously for Whittlesey, just tipping the scales to Whittlesey's favor. Giddings's persuasive friendliness and diligence on Whittlesey's behalf had won the day, according to this version. However, Giddings's comments to Whittlesey after the event wisely downplayed his role. Looking back on it two years later, Giddings confessed to Whittlesey that "the result taught me that I might some times be mistaken in political affairs." At the time of that 1822 election, Giddings had apparently led Whittlesey to conclude by election day that the result could not be in serious doubt. Despite pulling through in Ashtabula County, it is clear that Giddings felt some embarrassment over being unable to better inform Whittlesey of exactly how the election would play out. Nonetheless, it remained important to Giddings that he cement Whittlesey's attachment to him, so he continued to work diligently on gaining Whittlesey's approval. ${ }^{32}$

Whittlesey skillfully converted Giddings's loyalty to his political advantage. Eager to please his mentor, Giddings catered to Whittlesey's interests tirelessly, serving throughout much of the 1820 s and 1830s as Whittlesey's political eyes and ears on the Reserve. This was even more easily accomplished after 1823 when Giddings relocated to the village of Jefferson, seat of Ashtabula County, and built his home and office adjacent one another directly facing the courthouse square. At Whittlesey's encouragement, Giddings polled his chances in upcoming elections, tracked the ambitions of their friends, attended meetings of nascent political organizations to assess their potential impact, and followed the numerous ad hoc conventions which served at this time to declare political

\footnotetext{
${ }^{32}$ Author unknown, "Biography of J. R. Giddings" documentary fragment, George W. Julian Papers, ISL.; and Joshua Giddings to Elisha Whittlesey, 28 September 1824, Elisha Whittlesey Papers, WRHS.
} 
positions or select candidates. It all functioned as a token of remuneration to Whittlesey for helping to launch Giddings's career; however, it also reassured Giddings that he was indispensable to Whittlesey. In 1828, Giddings even boasted how he had honed his predictive abilities since the near debacle of 1822:

Don't laugh for this attempt at mathematical calculation. I have long been of opinion that by proper attention the events of an election might be foretold with some degree of mathematical certainty .... . You may think I am too sanguine in my own opinion, but I think I have dispassionately considered upon it and have deliberately sought information from every source in any way. . .

Whittlesey thrived on Giddings's detailed political reports, much preferring personal letters to newspaper reports. On one occasion he instructed Giddings , "I want to know all and something more."33

Giddings was a willing assistant. Even as he amassed significant personal wealth and professional eminence, his accession to Whittlesey's political wishes remained constant. One temporary period of political disillusionment still did not preclude his pledging the congressman his dedicated support. During one such time, he wrote,

But [I] have become so disgusted with the versatility of popular favors that I have about concluded to withdraw altogether from political concerns. . . . except as to member of Congress. ... I shall ever deem it a privilege to exert myself on that subject while your name is on the list of candidates.

Apparently also responding to a request from Whittlesey that Giddings not overdo his efforts on Whittlesey's behalf, Giddings continued, "But I must protest against your ever speaking to me about 'becoming bothersome to your friends.' It is possible that I have not been as active on the subject as duty required. If so it was ungrateful neglect for which I ought to apologize." Perhaps inured to the

33 Joshua Giddings to Elisha Whittlesey, 15 July 1828; Henry Howe, Historical Collections of Ohio in Two Volumes, Vol. 1 (Cincinnati: State of Ohio, 1900), 269; Condensed History of Jefferson, Astabula County, Ohio (Jefferson: J. A. Howells and Co., 1878), 44-50; and Davison, 89. 
dependent nature of his relationship to Whittlesey, Giddings once told his mentor that he occasionally laughed at the "political squabbles" occurring in many parts of the nation. "Here," he wrote, "I react and admire that which pleases me, without the risk of being called a sycophant or office-seeker." Giddings's attraction to politics increased over time, and he followed Whittlesey's example by serving a term in the Ohio legislature. From Washington, however, Whittlesey needed the connection Giddings provided to political events back in Ohio. Eventually, Giddings realized that he indeed had been Whittlesey's political minion. $^{34}$

During this time Giddings ardently sought all that Whittlesey's friendship and example offered, later admitting that as a young man he "lived for the purpose of ambition, distinction, and honors." He followed a predictable path to respectability for the period: prominent roles in his church, fraternal, and benevolent organizations, and close association with his influential mentor. Giddings diligently built on any advantages provided, believing that man's morality was tied up with his dedication to professional ambition. He became expert in criminal and maritime law. With Whittlesey's quiet aid, Giddings successfully prosecuted a sensational medical malpractice suit before the state supreme court that won him accolades throughout the region. He followed Whittlesey into the American Colonization Society and the Free Masons, eventually becoming an officer in the state Masonic lodge at Columbus. A term in the state legislature in the mid-1820s bored him, but a passion for politics developed throughout the decade as he guarded Whittlesey's political interests and shepherded their political allies on the Reserve. Giddings's concurrent ragsto-riches ascent gave the outward appearance of confirming the prevailing mythology that asserted a connection between the growing individualism of a republican democracy and boundless market-driven opportunities in the vast

\footnotetext{
${ }^{34}$ Joshua Giddings to Elisha Whittlesey, 27 August 1830 and 10 January 1828, Elisha Whittlesey Papers, WRHS.
} 
American landscape. In the back of Giddings's mind, however, he never lost the nagging awareness that occasionally self-appointed aristocrats looked down on him, and toward that attitude he carried a "lifelong hatred". ${ }^{35}$

\section{"Hypo"}

Despite all that Giddings learned about gaining an enviable reputation, one potential peril to its maintenance he battled without Whittlesey's aid-perhaps even without his knowledge. Depression and infirmity plagued Giddings periodically throughout his adult life. He wrote of recurrent bouts of "hypochondria" or "hypo," which he described as periods of illness, "melancholy," and "low spirits." Known also as "ennui" to antebellum physicians, "hypo" struck only males and was characterized by "dullness, fear, indefinite pains, and the lack of desire to attend to any business." Stress, despair, and disease were especially threatening to nineteenth-century males, who recognized the importance of maintaining constitutional resilience in that competitive environment. Nervous conditions were not only labeled "feminine," but they signaled in men an inability to maintain control over emotions. Even more potentially dispiriting, the general reform ethos of the period sometimes imparted moral overtones to physical well-being and included the notion that illness was potentially a matter of moral concern. Understandably, many men in the early republic feared the personal destabilization that infirmity or temperamental weakness predicted for their lives. ${ }^{36}$

${ }^{35}$ Davison, 40-41 and 109-11; Joshua Giddings to Lura Maria Giddings, 8 January 1840 and Joshua Giddings to Joseph A. Giddings, 1 June 1842, Joshua Giddings Papers, Maag; Stewart, -10; Buell, 26-34; Marvin Meyers, The Jacksonian Persuasian: Politics and Belief (New York: Vintage Books, 1960) on the issue of land acquisition as a vehicle of social ascent; and Daniel Feller, The Jacksonian Promise: America 1815-1840 (Baltimore: Johns Hopkins University Press, 1995), 7-8.

${ }^{36}$ Sounding much like today's anxiety and depression, "hypo," according to frontier doctors, included among its causes "hard drink, fevers, gout, night air, scolding companions, or intense thought." The preferred treatment was "cheerful company and a light diet." Females were not diagnosed with "hypo;" they suffered "hysterics." See R. Carlyle Buley, The Old Northwest: Pioneer Period, 1815-1840 (Bloomington: Indiana University Press, 1950), 263. On the implications of infirmity for men, see Phillip Andrew Gibbs, "Seasons of American Manhood, 1750-1860): Mirror of the Changing Republic" (Ph.D. diss., Mississippi State University, 1988), 114-116 and 
Giddings's depressive bouts often accompanied alarming physical symptoms, including severe heart palpitations. During such times, Giddings revealed a gloomy sense of foreboding, clearly anticipating that his condition might be life-threatening. Stricken ill away from home on one occasion, Giddings confessed to his wife:

[L]ast night I was taken about twelve o'clock with a severe palpitation of the heart, which as usual is attended with great depression of spirits and gloom of mind. In such cases I think of home, of wife, children, and friends. You can hardly imagine how fleeting and transitory all the pomp and circumstance ... appears when I am afflicted in this way. ... The church bell will soon ring and I will then try to get to meeting and get my mind on the subject of futurity, which is quite natural in such times. ${ }^{37}$

Giddings's doctor advised travel as a palliative, which usually helped him considerably. Once arrived at his destination, however, Giddings's "hypo" often returned. Travel throughout the Old Northwest was often precarious and unreliable, but Giddings recognized the value of challenging activity and constant diversion in keeping his symptoms at bay. A man who worked as hard as he deserved more time with his family, he once complained, but if he remained at

205-212; Roberta J. Park, "Biological Thought, Athletics and the Formation of a 'Man of Character': 18301900," in Manliness and Morality: middle-class masculinity in Britain and the America 1800-1940 (Manchester: Manchester University Press, 1987), eds. J. A. Mangan and James Walvin, 7-13; Buley, 312; and Edward Pessen, Jacksonian America: Society, Personality, and Politics (Urbana: University of Illinois, 1985), 47 and 65.

37 Joshua Giddings to Laura Giddings, 12 January 1840, Joshua Giddings Papers, Maag. Giddings also suffered from nagging dyspepsia, but the exact cause of his various complaints remains somewhat unclear, possibly due to the state of medical diagnosis at the time. One biographer describes his condition as "an affection of the nervous system acting upon the heart." Giddings's expectations that he might die suddenly appeared to come true on two occasions in the late 1850s, when he collapsed as if dead on the floor of the House of Representatives, only to later revive. His illness continued for a half-dozen years more before finally proving fatal-something that he had by that time anticipated for decades. The Biographical Encyclopaedia of Ohio of the Nineteenth Century, Charles Robson, Ed. (Cincinnati: Galaxy Publishing Company, 1876), "Joshua Reed Giddings." 
home "melancholy and depression of spirits would constantly prey upon my mind." 38

In 1835, Giddings sought treatment through therapies available at the fabled Saratoga Springs mineral spa resort in upstate New York. Normally, only a fraction of spa-goers there sought relief from actual illness. Most visited to maintain tolerable health, escape summer heat and boredom, or join the endless parade of social events scheduled to break the monotony of spa therapies. Thousands of influential and wealthy Americans made spa vacations an annual rite. For example, politician Henry Clay vacationed in the late 1830 s at Saratoga Springs resort, where he was feted with a dinner for eight hundred guests. Alongside the galas, promenades, and hoopla of an occasional political rally, Giddings could quietly seek relief without drawing undue attention to his destabilizing episodic illness. ${ }^{39}$

Writing son Joseph-whom everyone called Addison-from the springs, he confessed that he had been ill, "very low spirited and very melancholy." Although feeling somewhat better now, he still wondered about the completion of the travel he planned through New England, New York, and Pennsylvania. "But how long it will take I cannot say," he pondered, "and perhaps I may not live to

${ }^{38}$ Joshua Giddings to Laura Giddings 22 April 1837, Joshua Giddings Papers, Maag. On travel conditions, see Buley, Chapter Seven.

${ }^{39}$ The best general treatment of mineral spa culture in the United States is Thomas A. Chambers, Drinking the Waters: Creating and American Leisure Class at Nineteenth-Century Mineral Springs (Washington: Smithsonian Institution, 2002). Resort spas of upstate New York receive special attention in Theodore Corbett, The Making of American Resorts: Saratoga Springs, Ballston Spa, and Lake George (New Brunswick, NJ: Rutgers University Press, 2001). Chapter Thirteen discusses the types of visitors these three spas enjoyed and contains the report of Henry Clay's visit to Saratoga Springs. Charlene M. Boyer Lewis illuminates the southern mineral spa culture in Ladies and Gentlemen on Display: Planter Society at the Virginia Springs, 1790-1860 (Charlottesville: University Press of Virginia, 2001). All three authors note the class-based structure at mineral spa resorts at this time, but also that a small percentage of visitors attended for relief of physical maladies rather than the opportunity to mingle and display status. Status-seeker though he truly was, there is no evidence that Giddings intended or attempted to use his time at Saratoga Springs to rub shoulders with the rich and influential. 
accomplish it." By contrast, a letter written to law partner Benjamin Wade the very next day exhibited a confident and even lighthearted tone. The "water cure" at Saratoga had helped him a great deal, he said, and he drank "a little short of a barrel a day." He and the spa's other off-season visitors formed an "invalid society," he joked lightheartedly, "over which I have the honor to preside. . . . That duty I perform with 'awful dignity'." Although Wade, as his legal partner, worked closely enough with Giddings that he probably knew the psychological aspect of his illness, Giddings's letter to this male peer nonetheless portrayed a competent, composed self, actively seeking a return of health. His selfdeprecating humor acknowledged the potential his situation held for embarrassment without revealing the level of discouragement that also accompanied it. ${ }^{40}$

On the other hand, correspondence directed to Whittlesey throughout their relationship occasionally refers to bouts of common illnesses, such as bad colds or regional cholera scares, but never Giddings's struggle with the "hypo." Although Giddings regularly reminded Whittlesey that their friendship depended upon mutual frankness, trust, and confidentiality, he apparently reserved the honest details of his episodic illness for his family. Consequently, this political patriarch and professional father-figure received news of Giddings's health when he suffered ailments to which all people were susceptible, not descriptions of the private contest Giddings waged to overcome his depressive illness and the alarming physical symptoms that accompanied it. More to the point, Giddings typically represented himself to Whittlesey as a man who was content, independent, and emotionally self-sufficient. If the older and more powerful man

40 Joshua Giddings to Joseph A. Giddings, 21 May 1835 and Joshua Giddings to Benjamin Wade, 22 May 1835 , Joshua Giddings Papers, Maag. Benjamin Wade, who also studied law under Whittlesey's tutelage, is best known for his later activities as a Radical Republican senator from Ohio. Wade's exposure to Giddings's personal life would have been heightened by the fact that their office was located in the side yard of the Giddings house. 
was also aware of Giddings's ongoing struggle with "hypo," he and Giddings avoided that subject. Giddings's impressive muscular build misled others into assuming he enjoyed uncomplicated health, and Giddings revealed to only a select few that it was a lie. ${ }^{41}$

Giddings knew that a man's public character ultimately depended on the opinions of others. Undoubtedly, he recognized the negative potential a protracted battle with depression had for opinions of his masculine competence, admitting his vulnerability only to his immediate family and, to a lesser degree, his business partner. Given the intense social culture of Giddings's legal and political circle-and his desire to replace Whittlesey someday in CongressGiddings was preoccupied with his reputation. Moreover, he had always believed in the necessity of a strong physical constitution to any man's success in life. Consequently, episodes of illness could throw him into paroxysms of despair. ${ }^{42}$

Paradoxically, Giddings's physical strength was the substance of Western Reserve legend. There, he occasionally amazed onlookers by holding a young child in a single outstretched arm, the youngster standing solely upon his open palm. Tall, muscular, and athletic, Giddings was known at home for his wrestling abilities, love of baseball, and competence out of doors. A palpable sense of his powerful physical competence led him to fear almost nothing except the despair and fatalistic melancholy that accompanied his regular, solitary bouts of illness. ${ }^{43}$

It may have been the reassuring rigors and challenge of early nineteenthcentury travel that appeased Giddings's dispirited moods as much as the actual

\footnotetext{
${ }^{41}$ In 1831-32, a cholera epidemic struck with special force in the transappalachian West. See Buley, 252-253.

42 Joshua Giddings to Elisha Whittlesey, 17 July 1828 and 22 January 1837, Elisha Whittlesey Papers, WRHS; and Author unknown, "Biography of J. R. Giddings" documentary fragment, George W. Julian Papers, ISL.

${ }^{43}$ Howe, 269; and, 5.
} 
change of scenery. Confronting physical obstacles seemed to lift his spirits and replenish his emotional energy. Traveling by boat across Lake Erie on one occasion, he said he felt better and "not so much troubled with hypochondria," even though "the bedbugs were so thick we could not sleep except we stood up on the promenade deck where the wind blew pretty throughly." Indeed, the subsequent struggle through thick Michigan woods was so arduous that it left him no time to indulge his melancholia. He felt at home in the Western wilds, where he "ate pone and pork in the woodsman's shanty," and had the best sleep of his life, "although" he wrote, "I had neither bed nor mattress, pillow nor blanket." Grown to manhood clearing thick forest for homesteading family members, Giddings was comfortable confronting environmental obstacles. Uncomplicated by issues of social status or professional competition, these primitive challenges rejuvenated him and seemed to offer a respite from the discouragement of the "hypo." 44

This vital part of his nature, the emotional strength he drew from physical challenge, remained largely absent from what he revealed of himself to other men. Even confessing the salutary effect of nature's sublimity to his wife embarrassed him a little. Conquering obstacles to long distance travel was a safer topic, as it challenged everyone's endurance at this time, and Whittlesey's yearly trip across the Allegheny Mountains for Congressional sessions could be downright life-threatening, on occasion. Still-his occasional trite romanticisms aside-something touching exists in Giddings's poignant confessions of how rusticity rebalanced the rising lawyer who had once been a rough-hewn farm boy. That may have been precisely what he did not want Whittlesey to see. ${ }^{45}$

44 Joshua Giddings to Laura Giddings, 14 July and 20 July 1837, Joshua Giddings Papers, Maag.

${ }^{45}$ Giddings asked his wife not to laugh at his romantic descriptions of the natural prairies around Chicago, saying had she seen them, she would have been similarly moved. Joshua Giddings to Laura Waters Giddings, 20 July 1837, Joshua Giddings Papers, Maag. 


\section{Antimasonry}

For men in the early republic whom scholars would later label middle class, expanded democratization and changing modes of production and marketing promoted lives increasingly characterized by social and economic independence ${ }^{46}$ However, many realized they needed to cooperate with other men to succeed, and many still found they needed the camaraderie and acceptance of other men, which they-Giddings among them-found in the Masons or other fraternal associations. The men in Giddings's circle most successfully resolved this tension by conflating political alliance with friendship. The appearance of universal white male suffrage led to a "new male political culture" in the 1820 s based on party association and "competing self-interests." In Ohio, these arrangements were particularly strong at the county level. Giddings's regional network of political allies offered relative social safety for members by providing an outlet for individual ambition closely monitored and regulated by the group of peers. This social arrangement mirrored the developing culture of the antebellum legal bar, probably owing to the fact that, on the Reserve, leadership in law and politics was largely pursued by the same group of men. Friendship, expressed dually as loyalty to group goals and individual

${ }^{46}$ When possible, I avoid using the term middle class because the historical subjects here under examination did not use this terminology, nor had they articulated exactly what the developing class structures of the early nineteenth century signaled or represented. Most often, people in Giddings's circle used the term "respectability" to describe what scholars now assume are developing middle-class values. Giddings's cohort used the word "class," but not to mean position on a hierarchy of social rank. While I acknowledge the significance of the developing ethos of middle-class identity during this period, I do not want to prejudice the narrative in such a way to color a full understanding of how Giddings and his acquaintances understood and articulated their world. On the development of middle-class identity in the nineteenth century, see Stuart M. Blumin, The Emergence of the Middle Class: Social Experience in the American City, 1760-1900 (Cambridge, UK: University of Cambridge Press, 1989); Karen Halttunen, Confidence Men and Painted Women; Mary P. Ryan, Cradle of the Middle Class: the Family in Oneida County, New York, 1790-1865(Cambridge, UK: University of Cambridge, 1981); Edward Pessen, Riches, Class, and Power: America Before the Civil War (New Brunswick: Transaction, 1990); and John F. Kasson, Rudeness and Civility: Manners in NineteenthCentury Urban America (New York: Hill and Wang, 1990. 
ambitions, offered a means by which Giddings and his peers confronted the competing bipolar forces of kinship and competition inherent in the early bar. ${ }^{47}$

Lawyers predominated in the men who ran for elective office at the state and national levels. In fact, it was politics, more than law, which came to define and cement the relationships of Whittlesey, Giddings, and the men with whom they closely associated. Various regional alliances existed, but they remained somewhat hard to define until sometime in the 1820s. During that decade, a new party system was still emerging out of the political fallout from the demise of the old Federalist-Anti-federalist schema that had taken root in the late eighteenth century. From that time until the late 1820s, men in the United States tended to align themselves according to the national leaders they favored.

Around that time, rancor in Washington between friends of President John Quincy Adams and Henry Clay on one side and supporters of Andrew Jackson on the other worked to polarize voters, who increasingly now claimed affiliation with one side or the other. The Adams-Clay men-included Whittlesey and Giddings-frequently identified as National Republicans, while Jackson men were known as Democrats, or colloquially as "Jacksonians," and later also "Van Buren men." However, no envisioned denouement mandated a two-party system, or that it should remain tied to national political leaders. Indeed, the two camps soon began claiming ideological views around which they encouraged potential voters also to rally. In those days, pockets of concerned voting men anywhere could hold nominating conventions without reference to any party or particular group identity. Men present at such gatherings might endorse a candidate from

\footnotetext{
${ }^{47}$ Rotundo, 218; and Andrew R. L Cayton and Peter S. Onuf, The Midwest and the Nation: Rethinking the History of an American Region (Bloomington: Indiana University Press), 68. See also Mark C. Carnes, "Middle-Class Men and the Solace of Fraternal Ritual," in Meanings for Manhood: Constructions of Masculinity in Victorian America, ed. Mark C. Carnes and Clyde Griffen (Chicago: University of Chicago Press, 1990), 37-52. .
} 
either of the developing major parties, ally with a smaller alternate party, run their own unaffiliated candidate, or endorse absolutely no one at all. ${ }^{48}$

Despite the relative instability of politics in the early decades of the nineteenth century, Reserve men still formed political alliances. Giddings and Whittlesey took theirs very seriously, always referring to members of their political cohort as "our friends." By the end of the 1820s, their circle of district men was united mainly by a visceral dislike of Andrew Jackson and the inordinate greed for power they believed his party represented. Moreover, if the presidency of a scholarly, statesman-like New Englander like Adams could be overturned by a hothead Tennessee frontiersman, what fearful message might Adams's regional kinsmen in Ohio imbibe regarding the potential outcome of their own orderly, serious preparations for success? The majority of men on the Reserve might have disagreed over whether Adams or Clay represented the best national leader around whom to rally, but their alliance and identity was cemented by opposition to Jackson. ${ }^{49}$

Anti-Jacksonians held healthy majorities in the northern three counties in the sixteenth congressional district, including Giddings's home of Ashtabula County, but in Trumbull County, where Whittlesey lived, voters divided more evenly. Normally, nomination in the district as the anti-Jacksonian candidate for Congress was tantamount to election. However, if multiple candidates ran who might appeal to the Anti-Jacksonian voters, victory for any one of them became less likely. United, the anti-Jacksonians stood; divided, a Jacksonian or other

${ }^{48}$ On the political culture of early Ohio, see Donald Ratcliffe, Party Spirit in a Frontier Republic: Democratic Politics in Ohio, 1793-1821 (Columbus: Ohio University Press, 1998). The best source of any particular region's nineteenth-century political culture is local newspapers, as they were overtly partisan and carried more political reporting than what we today consider actual news.

49 Two useful recent treatments of the significance of Jackson's elections—to both sides-are Lynn Hudson Parsons, The Birth of Modern Politics: Andrew Jackson, John Quincy Adams, and the Election of 1828 (New York: Oxford University Press, 2009); and Donald B. Cole, Vindicating Andrew Jackson: The 1828 Election and the Rise of the Two-Party System (Lawrence, Kansas: University Press of Kansas, 1999). 
interloper could sneak in a victory, or even influence the outcome of local and state elections also being decided. In fact, political instability of any kind could threaten to derail candidates standing for any number of offices. Consequently, Giddings, Whittlesey, and "friends" took all threats to the political success of their allies seriously-sometimes even personally-even as they recognized the necessity of riding out the occasional disruptive political wave.

This truth is probably best illustrated by the "rash, rabid, and uncontrollable" Antimasonic frenzy that swept parts of the North in the late 1820s and early 1830s. Its precipitate was the mysterious 1826 disappearance of William Morgan, a western New York man who had threatened to reveal Masonic secrets. From the tainted investigation that followed grew the general suspicion that powerful men benefited from a clandestine Masonic culture of fraternal preference and loyalty, in effect subverting the democratic process. Giddings puzzled over the reactions of his neighbors, who he said were poised to "run crazy" on the subject. ${ }^{50}$

Freemasonry was established on the Reserve in 1808, with original connections to the Grand Lodge of Connecticut. It was never a problem for Whittlesey's political life before, despite his being a founder of the first lodge in Trumbull County, located in his own home of Canfield. In fact, at the time of the Antimasonic uproar, the Reserve contained one-fourth of the Masonic lodges in the entire state of Ohio! Ironically, Masonry's strength on the Reserve was also its eventual downfall: the shear mass of rising men who appeared to be colluding

\footnotetext{
50 Joel H. Silbey, Martin Van Buren and the Emergence of American Popular Politics (Lahman, Maryland: Rowman and Littlefield, 2002), 53; Pessen, Jacksonian America, 263-265; and Giddings to Whittlesey, 6 July 1832, Elisha Whittlesey Papers, WRHS. Although his study focuses only on the Antimasons in New England, probably the most thoughtful examination on this topic is Paul Goodman, Towards a Christian Republic: Antimasonry and the Great Transition in New England, 1826-1836 (New York: Oxford University Press, 1988).
} 
together to control the reins of power left the region especially vulnerable to suspicion that some might be perverting republican ideals. ${ }^{51}$

In the brouhaha following Morgan's disappearance, normal social relations on the Reserve heaved. Reputations under fire, hordes of Masons across the country made public confession, hoping to avoid condemnation by townspeople and churches. ${ }^{52}$ Giddings was horrified that his own hard-won reputation might suffer permanently; nonetheless, he bristled that years spent struggling for offices or honors, legitimate public markers of respectability, could potentially all be for naught.

The Reserve reverberated with Antimasonic enthusiasm. Consequently, ambitious men recognized they might advance political careers by aligning with the expanding movement. Further upsetting the region's political equilibrium, many incoming New Englanders during this period were going Democratic. The powerful anti-Jacksonian network of Whittlesey's and Giddings's friends began to unravel. Fulfilling the worst fears of some, Whittlesey's longtime colleague Jonathan Sloane assumed a leadership role in the budding Antimason confederation, thereby challenging Whittlesey's regional political hegemony. Both groups now angled for influence, dividing the Reserve's loose anti-Jacksonian coalition and violating the understood interrelation of friendship and political alliance.

Throughout his long political career, Whittlesey's primary preoccupation remained that constituent allies agree on a single candidate and not invite Democratic insurgency. Giddings's concerns during much of the Antimasonic imbroglio were of a more personal nature. Recently elevated to high office in the

\footnotetext{
${ }^{51}$ Davison, 87-88.

${ }^{52}$ Goodman, 6-12.
} 
state Masonic lodge, Giddings became a primary regional target. A weekly Antimasonic paper published in the district trumpeted opposition to exalted "High Mightinesses" with Masonic titles, and insisted that freemen had a right to demand of the new "Right Worshipful Grand Junior Warden of the Grand Lodge of Ohio" what were the "purposes, designs, and benefits of such an office." Contributors and correspondents excoriated Giddings for the aristocratic posturing that supposedly characterized Masonic officeholders. They also averred that his acts of Christian benevolence were hypocritical. Noting that Giddings was concurrently serving as senior vice-president of the Sabbath school society, one critic challenged him to "reconcile the oaths and principles of Masonry with the principles professedly taught in the Sabbath School." Another man mocked references Giddings had made to a young household ward while defending his charitable character: "Sir, could you not vindicate the cause of so honorable and ancient an institution as Freemasonry, without the assistance of a School Girl?"53

These kinds of assaults ran exactly counter to Giddings's ideas about how men should deal with each other. Furthermore, some charges stung because they nearly resembled truth, such as one critic's exclamation that "it is astonishing to what pitch of emulation and ambition human nature will climb!" Unmasked and infuriated, Giddings fumed to Whittlesey over the schemes of the Antimasons-including former anti-Jacksonian colleagues-to undermine his good reputation:

Everything is brought to bear upon us which fanaticism, party spirit, personal envy, church quarrels, neighborhood difficulties, superstition, malevolence, ignorance, vanity, and the most impudent falsehoods can invent ... . [H]ow far their fiendlike designs may succeed God only knows .... . The plan is to put down the character of every Mason who does not renounce, to thrust

${ }^{53}$ Ohio Luminary, 12 February and 19 February 1830. Also see Stewart, 12-14. 
every one from office, from churches, and by ruining their characters to render them unable to regain a standing in society. ${ }^{54}$

This vile plan deranged Giddings, challenging the cherished public life that now assured him he had shaken off his low beginnings. Indeed, one of Masonry's most salient features was the role it played in confirming respectable status, especially to rising young men. Appealing especially to businessmen and professionals, it offered an immediate circle of friendly contacts, as well as the potential of fraternal recreation. Giddings had leveraged a brief stint as representative in Columbus into a networking venture that lifted his status in the state Masonic lodge. Because higher ranking Masons paid higher dues, Giddings's position testified not only to the respect of his fraternal brothers, but his wealth, as well. ${ }^{55}$

It was not just Giddings's choice of fraternal organization coming under fire at home, then, but also his highest social achievement to date. The implications went much deeper, however. Antimasonic demands for public renunciation resembled nothing as much as the immediate repentance expected of sinners on the anxious seat at revivals or the insistence tipplers take a temperance pledge. Here was Giddings, then, a well-known guardian of social values, now cast in the role of impenitent sinner! The reformer now found himself in the unhappy position of being the object of others' reforms. No wonder he was angry at this very public humiliation. All of this posed a troubling dilemma for Giddings: to cave in to his critics now would discredit Giddings as a Christian reformer.

54 Ohio Luminary, 20 March 1830; Giddings to Whittlesey, 17 July 1828 and 26 July, 17 October, and 23 November of 1832, Elisha Whittlesey Papers, WRHS; Donald J. Ratcliffe, "The Market Revolution and party Alignments in Ohio, 1828-1840," in The Pursuit of Public Power: Political Culture in Ohio, 1787-1861,ed. Jeffrey P. Brown and Andrew R. L. Cayton (Kent, Ohio: The Kent State University Press, 1994), 116; and Gerald McFarland, A Scattered People: An American Family Moves West (New York: Penguin Books, 1987), 109-11.

${ }^{55}$ Goodman, 13 and 46-50. 
His standing sustained by deeper roots, Whittlesey counseled cooperation with the malcontents. Moreover, he served at the popular will. As a politician around whom district men had repeatedly unified—and alert to the possibility of a coup-he sought some way to reassure Reserve neighbors grown especially wary of powerful men. Whittlesey quietly led a movement to surrender Masonic lodge charters across the Reserve and hoped it would dampen regional "excitement." Giddings regained his equilibrium and again became Whittlesey's helpmate, eventually even suggesting the more extreme move of closing the state lodge. Spurred by public abuse, Giddings began to see some wisdom in downplaying the mark of respectability he thought Masonic leadership had conferred-especially if the loss could be made to hit Masons across the board. ${ }^{56}$ $\mathrm{He}$ recognized the value of maintaining masculine cooperation, whenever possible.

In a master stroke of political maneuvering, Giddings also aided the creation of a local Workingmen's Party to draw off half-hearted Antimasons and other district populists still wary of the National Republicans through which Reserve men usually fielded Whittlesey's candidacy. Exactly as Giddings planned, the Workingmen also nominated Whittlesey, and the previously fractured cohort limped to victory over Democratic foes. Still smarting slightly, a nonetheless resolute Giddings remarked that it was finally time to end the "political divisions and animosities of those who should be friends." Even the earlier "malevolent" personal attacks and "fiendlike designs" of the Antimasons did not preclude the acceptance of errant friends back into his circle of intimates once the political crisis had subsided. In this crowd, friendships entailed unshakable political fealty-here beginning to take shape in the form of antiJacksonianism. Consequently, Giddings could assert very consciously to

${ }^{56}$ Davison, 87-88. 
Whittlesey that Jacksonians, their established political opponents, were, of course, "excepted" from consideration as potential friends. By the time the Antimasonic dust on the Reserve settled, Giddings had proven his loyalty to Whittlesey, his ability as a regional political operative, and his talent for mitigating not only potential divisions, but threats to his persona. ${ }^{57}$

\section{Awakening}

Somewhere alongside Giddings's rise to regional prominence the nature of his preoccupation with respectability and reputation shifted. That alteration appears tied to a personal awakening —or considerable strengthening-of religious feeling. Although reared by pious parents, Giddings says that for a time as an adult he questioned the faith that had been their example. Giddings later explained his spiritual path to a daughter in whom glimmers of independent religious thought concerned him:

On the subject of religion my opinion was not formed by education. I was much inclined to skepticism after I arrived to years of maturity. I was not only inclined, but wished to disbelieve. I entered upon a full and extensive investigation of the subject. I scrutinized it by the same rules that I would have sought to develop trust on every subject. I had long been in the habit of searching after truth, both in my office and in court. I felt prepared for the task. I searched diligently, faithfully, and earnestly. My mind was led to satisfactory conclusions. I was confirmed in the full belief of those truths. . . . Having made up my mind on the subject I have never failed to teach my children the principles in which I believe."

Giddings admitted to fourteen-year-old Maria that he shared this story to buttress his insistence that for the present she should trust his judgment on "religion and all other subjects." Giddings the legal man liked to imagine the

\footnotetext{
57 Joshua Giddings to Elisha Whittlesey, 17 October 1832 and 21 July 1836, Elisha Whittlesey Papers, WRHS. In some state elections, the Reserve's anti-Jacksonian factions agreed not to run candidates against one another to avoid dividing their votes.

58 Joshua Giddings to Lura Maria Giddings, 18 March 1840.
} 
foundation of his mental universe was a consistent adherence to fact, logic, and reason. After all, the bread and butter of any lawyer existed in convincing people that his thinking was correct.

The problem with Giddings's claim here regarding how he arrived at his religious faith is that it in itself defies all logic! By the time Giddings wrote that letter, his family had been enmeshed in the revivalist world of enthusiastic religion for years. They joined the throngs across the Reserve who craved religious excitement and a personal, emotional connection to faith. So enamored were many Reserve inhabitants of these fiery gatherings in this period that it led one visitor to note wryly that if churchgoers "were not actually enjoying a revival, they were on the look out." How could Giddings reconcile his recollection of applying a cool-headed, lawyerly approach to the topic of religious truth with his own religious reality ${ }^{59}$

For one thing, the general culture promoted the idea that reasoned consideration underlay belief regarding just about any topic. "Knowledge" was hailed as nearly akin to virtue, even among evangelical religious enthusiasts. Schools, reform or religious organizations, and burgeoning political parties counted on society believing that exposure to correct facts led almost inexorably to the discovery-and acceptance-of truth. Otherwise, what was the point of the endless rallies, debates, lyceums, lectures, and printed materials that circulated so generously on the Reserve?

Perhaps just as important, Giddings had been publicly challenged to examine the sincerity of his religious beliefs in 1830, when under attack by Antimasons. Noting at that time that Giddings simultaneously held offices in the

${ }^{59}$ D. Griffeths, Jr., Two Years in the New Settlements of Ohio (Ann Arbor, MI: University Microfilms, Inc., 1966), 166. The Griffeths work was written in 1832. 
regional Sabbath school union and the state Masonic lodge, one contributor to an Antimasonic newspaper declared,

We publicly call upon this gentleman to reconcile the principles and practices natively and correctly flowing from the investiture of these offices to each other, and to the grand feature of evangelical morality; wherein they promote in all their bearing and ramifications the glory of Him who made and redeemed us . . ."60

Giddings was already involved in some of the evangelical reform movements of the day, of which the Sabbath school movement was only one example. Respectable men often promoted the general public good through religious channels, especially in places similar to the Reserve where a strong Yankee Protestant heritage underlay the very culture of most of its residents. Some men-Whittlesey, for example-donated money toward multiple churchbuilding projects. Others supported Western Reserve College, a Congregational school in Hudson and the pride of the Reserve in the early nineteenth century. The Masons in some towns donated money to build churches and schools, often with the understanding that during "off" hours the organization could use the building for its meetings. Giddings's position as Senior Vice President of the Ashtabula Sabbath School Union indicates he was fully involved in the evangelical reform community, but the point his critic was making was that Giddings was just collecting one more office to add to the leadership roles he coveted. ${ }^{61}$

Giddings fought back. One opponent quotes Giddings as saying, "To him who sits upon the throne of the Universe I am accountable for my religious faith, and to him alone I either stand or I fall." This critic would have none of it, however, and filled an entire newspaper page with a harangue on the insincere nature of Giddings's religious faith. The very question of whether Giddings was a

${ }^{60}$ Ohio Luminary, 19 February 1830.

${ }^{61}$ Whittlesey contributed toward the construction of both the Methodist Episcopal and Congregational churches in Canfield. See History of Trumbull and Mahoning Count Vol. 2, 18 and 25. 
fraud now resided in the public consciousness. It was a question Giddings was probably asking himself, even as he defended his religious sincerity by reciting a list of his good civic works.

Good deeds were not enough, according to his Antimasonic examiner. Giddings was a leader in the regional Sabbath school movement, and citizens needed to know they could trust him with the future of their children's souls. After all, the object of the movement was "the instruction of children and youth in the Holy Scripture, the Word of Almighty God; to enlighten their souls in the principles of the Bible in anticipation that means will result in their eternal blessedness and glory." Perhaps Giddings could defraud himself regarding his religious sincerity, but was he willing to take such liberties with other people's children?

Hard as he fought, this challenge to Giddings's personal legitimacy joined the other nagging doubts that he carried in the back of his mind. Was he educated enough? Would elite men respect his insistence on being accepted as their equal? Could respectable men butt heads without ravaging each other's reputations? Giddings thought he had settled the most important issue of whether he was a legitimate and acceptable choice to represent the interestsindeed, the voice-of Reserve inhabitants, either through civic or political organizations. Much later, Giddings confided to his daughter that once, he had indeed "lived for the purposes of ambition, of distinction, and honors." Only fortyfive at the time, Giddings felt so old that he said he now lived to promote the "honor, virtue, and bearing" of his children. But in 1830, with the Antimasons dogging his heels, Giddings must have been asking to what end he had sought all the honorifics they accused him of hoarding. ${ }^{62}$

${ }^{62}$ Joshua Giddings to Lura Maria Giddings, 8 January 1840. 
It was a perfect season for soul-searching. As the 1830s dawned, the vicinity around Jefferson was rocked with a particularly intense wave of religious fervor. Revivals fires burned so bright that for years after, Reserve residents bemoaned the loss of the general glow of non-sectarian Christian love that blanketed the general region at the beginning of the decade. There was no Congregational church in Jefferson in 1830, so townspeople desiring worship in an affiliated church most likely traveled five miles west to Austinburg, where a particularly energetic Congregational church had existed for decades under the oversight of Reverend Giles H. Cowles. However, Reverend Cowles also frequently ministered to inhabitants in Jefferson as part of his regional circuit. When Giles Cowles retired about this time and son Henry took the pulpit, the Austinburg church enjoyed a series of intense revivals. By 1831, the number of adherents in the vicinity mandated that Jefferson also build its own Congregational Church—which it did under Giles Cowles's direction. ${ }^{63}$

Evidence exists that at some point—certainly before the mid 1830s—the Giddings family-Congregationalist in their background-became closely involved with the Cowleses and also with Samuel Hendry, a founding member and lay leader of the Jefferson Congregational Church. In fact, the Hendry house was very close to the Giddings residence in the courthouse square neighborhood of Jefferson. A lawyer like Giddings, Hendry held local or county political offices occasionally, but his interest in politics was at least matched by a passion for religion. If Giddings were going to do some soul searching after the confrontation by the Antimasons, and if a personal awakening_or recommitment-resulted from intense Congregational revivals in the Jefferson area nearly concomitant with the Antimasonic attack, then closer attachments to people such as the

\footnotetext{
${ }^{63}$ Condensed History of Jefferson,59. Local historians actually refer to the churches in question as Congregational-Presbyterian in nature during this period, but when the 1801 Plan of Union ended in 1837 they become purely Congregational, which was their leaning all along. The connection of the Cowleses to Jefferson is traceable in the Giles H. Cowles Papers, Kent State University Library.
} 
Cowleses and Hendrys around this time period is precisely the evidence one would expect to find. ${ }^{64}$

In any case, as the 1830s progressed-and as opportunity aroseGiddings drew even closer to many of the Reserve's more religious inhabitants. Since the early 1820 s, traveling evangelists had conducted numerous protracted meetings, prayer gatherings, and other revival activities throughout the Reserve. At some point well after establishing himself as a lawyer, Giddings also embraced a personal and enthusiastic religious style, despite the fact that he later rationalized it as the product of study and reason. In fact, Giddings not only approved of the controversial "new measures" Charles Finney and other evangelical revivalists employed to urge transgressors toward immediate repentance, but partnered with other religious men to promote at least one revival gathering among Reserve inhabitants. ${ }^{65}$

In 1835, Giddings and Hendry shared a letter sheet to write to Levi Sutliff regarding plans a small group of men were hatching for a religious revival in Warren, about thirty miles from Jefferson, between Jefferson and Canfield. The seat of Trumbull County, Warren was the earliest major Reserve center of

${ }^{64}$ Condensed History of Jefferson, 79 and 94.

${ }^{65}$ Two excellent sources describing the growth of enthusiastic religion on the Western Reserve are Griffeths, Two Years in the New Settlements of Ohio and William S. Kennedy, The Plan of Union or a History of the Presbyterian and Congregational Churches of the Western Reserve (Hudson, OH: Pentagon Steam Press, 1856). Giddings revealed little of his religious views in the sources or period here examined. Consequently, it is impossible to determine precisely the role they played in his masculine friendships. He reveals more of his religious views after his 1838 departure to Congress, mainly in published writings or speeches. An examination of those years provides the best view of his sacred sensibilities, although they may have evolved as antebellum sectional tensions increased. Although not the topic of this study, the evolving religious beliefs of antebellum reformers or policy-makers bear close scrutiny for the effect they had on all their relationships, gender-specific or otherwise. In Giddings's case, a Western Reserve background of New School Calvinism and intense revivalism eventually combined with an evolving perfectionism and romanticism to form a comprehensive backdrop for his particular reform-based cosmology-and his politics. The best overall examination of Giddings's congressional period is the Stewart biography, cited above. To trace the sociological and theological progression from New School Calvinism to perfectionism and millennial reform cosmology, see Leo P. Hirrel, Children of Wrath: New School Calvinism and Antebellum Reform (Lexington: University Press of Kentucky, 1998) and Robert H. Abzug, Cosmos Crumbling: American Reform and the Religious Imagination (New York: Oxford University Press, 1994). 
banking, commerce, and judicial activity. The men hoped scheduling the revival while court was in session would increase attendance. ${ }^{66}$

Levi was a son of local religious lay leader Samuel "Deacon" Sutliff, whose family resided just outside Warren in Vernon. Giddings had once lived in Vernon briefly while the Sutliff family's pastor, Harvey Coe, tutored him prior to his law training. While in this Trumbull County hamlet, Giddings became acquainted with regional families and nurtured friendships with several of them. On the occasion of Deacon Sutliff's death some years later, Giddings claimed a nearly lifelong acquaintance, possibly because the Sutliffs haled originally from the same Connecticut town as Giddings's father. Giddings, Hendry, and Levi Sutliff were all fairly substantial men whose activities would occasionally and quite naturally place them in the same orbit. This ad hoc committee targeted the bustling commercial and court center of Warren for their revival, where the crowd of potential converts might include some of their irreligious acquaintances of the legal world, and where enough provisions and host families could be found if the revival turned into a long-lasting event, as some did. ${ }^{67}$

This was to be no minor affair if the men pulled it off as planned. They targeted Warren because, according to Hendry, it was perhaps the "most important town in the Western country." Hendry and Giddings wrote about ways to ensure success, the main one being to gain the attendance of men referred to

${ }^{66}$ Samuel Hendry and Joshua Giddings to Levi Sutliff, 29 July 1835, Sutliff Family Papers, Sutliff Museum.

${ }^{67}$ On the significance of the related Sutliff and Plum families to establishing churches in the region surrounding their settlements, see Historical Collections of the Mahoning Valley (Youngstown, Ohio: Mahoning Valley HistoricaL Society), 395-401. Attempts by scholars to assign denominational attachment to Reserve inhabitants during the Plan of Union period of 1801-1837, by which Congregationalists and Presbyterians cooperated in the West, can be misleading. For example, most Reserve churches leaned heavily Congregational, but pastors who served them might be ordained as Presbyterians, such as Harvey Coe, and the churches were governed by a Presbytery and sent a member representative delegate to the Presbyterian Synod. Apparently, most of Giddings's closest religious associates identified with their New England Congregational backgrounds, so I normally identify them as Congregationalists. It is unclear if Whittlesey held church membership anywhere until he joined a Canfield Presbyterian church in his latter years. 
simply as "Finney" and "Foote." The former is obviously famous revivalist Charles Finney, just arrived in Ohio to join the faculty of nearly Oberlin College. The latter is likely one of the evangelist Foote brothers who occasionally ministered in Ohio. Foote had already expressed interest in the plan. Both preachers were apparently in Ohio at this time, and were well-known enough that organizers could expect a larger crowd, if they participated. Hendry and Giddings had already enlisted a number of men closely associated with evangelical religion in several surrounding counties. Included among them were the pastor of Jefferson's Congregational church and Henry Cowles of the Austinburg church, both of whom already had close ties to Harvey Coe, partly though his tutoring would-be ministers. Only a small number total would be told of the plan, however, lest someone "set the impenitent in that vicinity on their guard." However, wrote Hendry, among those who did know of it "already a goodly number are praying."

Hendry expected that there might be trouble finding a church agreeable to hosting the revival and predicted resistance from the usual source-"old, sour, bigoted, cold hearted professors of religion." "Many things" would have to be

${ }^{68}$ Ibid. On Finney, see Charles E. Hambrick-Stowe, Charles G. Finney and the Spirit of Modern Evangelism, (Grand Rapids, MI: W. B. Eerdmans, 1996) and Charles G. Finney, Charles G. Finney: an Autobiography (Westwood, New Jersey: Fleming $\mathrm{H}$. Revell, 1908). It is impossible to determine with certainty to which of the Foote brothers - Hiram, Lucius, or Horatio-Giddings and Hendry refer. All traveling preachers, they also were "more or less influenced" by Finney. Horatio was Finney's "assistant and companion" in the great revivals of upstate New York in the early 1830s. Hiram left Oneida Institute around 1833 and in the mid-1830s was one of the traveling antislavery evangelists known as the "Lane Rebels." While finishing his education at Oberlin College he stumped the Reserve for antislavery, also at some point later campaigning for Giddings for Congress. Lucius Foote served for a short time in the 1830s as pastor of the Congregational church in Jefferson, although the date is uncertain. Of the three men, Hiram is most associated with Finney in Ohio; in 1836, he and Finney joined Oberlin president Asa Mahan to plan a revival for the Oberlin church. A fourth brother, Horace, supported western evangelism but never became a clergyman. On the Foote brothers, see Charles A. Church, History of Rockford and Winnebago County Illinois from the First Settlement in 1834 to the Civil War (Rockford, IL: New England Society of Rockford, III., 1900), Chapter Twenty-One; Abram W. Foote, Comprising the Genealogy and History of Nathaniel Foote of Weathersfield, Conn., And his Descendants Vol. One (Rutland, VT: Marble City Press-The Tuttle Company, 1907), 290-291; The Oberlin Jubilee 1833-1883, ed. W. G. Ballantine (Oberlin, OH: E. J Goodrich, 1883), 59-73; and Richard Muelder Hermann, Fighters for Freedom: A History of Anti-slavery Activities of Men and Women Associated with Knox College (New York: Columbia University Press, 2005), 87-88. 
"carefully managed," he said. Giddings cautioned that the meeting would not be "profitable" unless the minister and church chosen were completely on board. Ever the politician, however, he suggested a wire-pulling maneuver to enhance their chances of having a favorable outcome: "Indeed, [the minister and church] should take the lead in the matter, and should be led to think that they are the movers of it and they will feel a greater responsibility and more anxiety for the results. "While it was not unusual to enlist the aid of several ministers for a proposed revival, this behind-the-scenes management of information seems especially apropos to one planned by legal and political men. ${ }^{69}$

Hendry and Giddings approached this proposed joint venture of fellow religious enthusiasts in somewhat different manners. Hendry is blunt, spouting bitter invective against the older, conservative church men who tended to stand in the way of revivals and protracted meetings. He takes a sterner and negative-perhaps he would say more realistic-view of challenges confronting the upcoming event: "[O]ne thing you may be sure of, and that is that so much as is aimed at in this thing will not be attended without serious conflicts with the grand enemy of souls, and the trial of the faith and patience and perseverance of Christians." Giddings, on the other hand, had crafted a personal approach to relating to other men that tended to diminish anger and resistance. He gently suggests in more positive language that for the meeting to be "profitable" a church and minister must agree to host the event. Far from tensing for expected resistance, Giddings suggests the minister and church would respond best to an idea they thought was their own-and work harder to guarantee the success of the venture. In this instance, it is more important to Giddings that the gathering be successful and cooperative than that the men in the ad hoc committee now planning it ultimately take credit. So thoroughly had Giddings identified with the Congregationalists in his vicinity by this time that he guarantees Sutliff may

${ }^{69}$ Ibid. 
expect the "cooperation of our people in the measure, and such assistance as can be afforded from this part of the country ..." Further, he assures Sutliff that Henry Cowles told him he would "endeavor to attend."70

\section{Cooperation}

It is not surprising that cooperation existed on a proposed venture among this group of Reserve men, given their general acquaintance and religious connections. They also clearly identified together in contradistinction to those "sour" and "cold-hearted" churchgoers of their acquaintance in the mid-1830s. However, Reserve men had shown themselves generally willing to partner for good causes since regional settlement began in earnest around 1800. At first, isolated families sought out neighbors for assistance building shelters or for simple, home-based worship gatherings such as had occurred in the Giddings family's first rude cabin. As settlement increased and the region began to prosper, some men stepped forward in ad hoc committees to oversee various building projects with a desire for the public good being their only major bond. Whittlesey donated money to the construction of two different Canfield churches despite the fact that he apparently belonged to neither one at the time. As Giddings rose to regional prominence, he worked harmoniously with numerous regional men as an attorney, election officer, political party leader, militia member, and churchgoer. He held memberships in numerous reform or fraternal organizations, a corporation formed to fund a road project, another aimed at founding a fire insurance company, a convention called in response to a crisis in specie values, a teacher-examination committee, and a nascent county historical society. In similar manner, men all across the Reserve became acquainted as they concomitantly found common goals around which to build cooperative

${ }^{70}$ Throughout his life, Giddings was never one to shrink from honors or accolades, but on this occasion-and perhaps because it relates to spiritual matters and involves co-religionists-he suggests letting others step to the fore. On the other hand, enough men knew of the plan that if it did fail-which he felt could happen without the church and minister on board-some might associate Giddings with the failed endeavor. Ibid. 
relationships. Giddings's readiness to collaborate with all kinds of men was one part desire to avoid making enemies-who posed a potential obstacle to success-and one part reflection of a culture of masculine cooperation that grew up alongside Reserve towns and villages. ${ }^{71}$

If Giddings did embrace enthusiastic evangelical religion in the very early 1830s, there is no evidence that it disrupted his friendship with Whittlesey, despite the latter's own preference for a more vague, providential Christianity. Their relationship functioned mainly in the political arena, anyway. Forged in the loyalty of early mentorship and professional generosity, Giddings's feelings for Whittlesey ran so deep that it was hard for him to imagine as he climbed his way to success that they could ever come under any serious threat. In fact, within a decade of Giddings's 1820 departure from Whittlesey's tutelage, it was also clear Whittlesey was completely confident in Giddings and in their friendship.

It was around this time that Whittlesey, Giddings, and law partner Ben Wade became deeply involved in land speculation. The western half of the Reserve was finally secured from Indian threat and speculators poured into the area as soon as the federal government released the lands for sale. Whittlesey had toured this area several times previously on other business and felt the potential for profit was great. Whittlesey, Giddings, and several other men invested jointly in large amounts of land in the Toledo area. Whittlesey also funneled money from eastern investors wanting in on what seemed a remarkable

\footnotetext{
${ }^{71}$ One good example of a group of regional men coming together to promote their common good is their 1848 creation of the Ashtabula Central Plank Road Company to promote building a road from Ashtabula harbor, via Jefferson, to the Pennsylvania and Ohio Canal in Trumbull or Mahoning County. See Acts of a General Nature Passed by the Forty-Seventh General Assembly of the State of Ohio Vol. XLVII (Columbus, 1849). Given the overwhelming political strength of Ashtabula County's anti-Jacksonian coalition, most of Giddings's cooperative ventures there may not have challenged his willingness to reach across political boundaries very much. It was the Jacksonian men who risked being left out of leadership opportunities in many Reserve counties, if they gave the appearance of being contrary.
} 
opportunity. Giddings traveled extensively overseeing their interests, even meeting with potential investors in New York City. ${ }^{72}$

At the height of "speculation fever," as it was called, so many men in the district were speculating in the Toledo area that they joked about running into each other there as soon as the court term expired. Levi Sutliff and his brothers also invested in Toledo area lands. Sutliff's younger brother Flavel once observed that Giddings appeared to have a reputation for finagling profitable land deals. Edward Wade, younger brother of Giddings's law partner, was so feverstricken that he seemed to his investment partners-which in one venture included Giddings and Whittlesey-to be imagining profits without limit. Speculative investment was actually out of character for Whittlesey, who once wrote, "A burning desire to get rich at once, by a splendid dash, is one of the demoralizing evils of the day." However, Giddings and the Wade brothers had all studied law under Whittlesey, who probably trusted their ability to handle the legal paperwork, which sometimes involved complicated layers of investors. Whittlesey also enjoyed very close ties to large and established Ohio banks from which he got loans easily, making him a desirable partner. ${ }^{73}$

By the early 1830s, then, respectable men across the eastern half of the Reserve seemed to be getting on very well, despite the Antimasonic frenzy that had temporarily disrupted normal relations. A number of thriving villages and towns dotted the landscape and although conditions were still rude by standards in the eastern states the future of the region looked bright. The completion of the Erie Canal in 1825 brought an increase in migration and opportunities for

\footnotetext{
${ }^{72}$ Davison does an excellent job of unraveling the details of the Whittlesey-Giddings's circle of investors. See Chapter Seven .

${ }^{73}$ Davison, Chapter Seven. The Whittlesey quote regarding get-rich quick schemes is on page 117 and comes from a letter Whittlesey wrote to Roger M. Sherman on 15 November 1836. Also see Flavel Sutliff to Milton Sutliff, 4 May 1836, Sutliff Family Papers, Sutliff Museum. .
} 
commercial exchange. Men appeared to be well on their way to making fortunes speculating in land, especially in the western half of the Reserve.

Certainly, the area was not free of tension. Some anti-JacksoniansWhittlesey among them-feared the country might suffer irreparable harm from Jackson's tenure in office. Whittlesey worried that it might eventually destroy national government "for all constitutional and practical purposes." Giddings commiserated in Whittlesey's apprehension, at one point also pondering if they might be facing the "last chapter in the history of our present republic." Alarmed though many Reserve anti-Jacksonians were, however, many remained optimistic enough in the 1830s to pursue land speculation and Whittlesey entertained audiences with an occasional Fourth of July speech. Tensions existed as well within the anti-Jacksonian crowd in Whittlesey's district. Several men-each hoping to enjoy a stint in Whittlesey's congressional seat-claimed their own loyal cliques and stood poised to challenge Whittlesey, if the right conditions beckoned. In addition, although religion thrived at this time, it did so a little too much for the comfort of all. Some Reserve inhabitants were too accepting of Mormonism, Adventism, and even the controversial self-named Prophet Mathias to suit their more traditional religious neighbors. ${ }^{74}$

\section{Antislavery}

It was in the vicinity of a Reserve village founded by some of these more conservative migrants that trouble began which shortly cast the whole region into upheaval. Tallmadge had been founded in 1808 as a religious colony of New England Congregationalists. Five years after, Elisha Whittlesey's more pious brother, Asaph, moved his family there and became a merchant, then shortly

\footnotetext{
${ }^{74}$ Elisha Whittlesey to Joshua Giddings, 17 January 1831, Joshua Giddings Papers, Maag; and Joshua Giddings to Elisha Whittlesey, 26 June 1832, Elisha Whittlesey Papers, WRHS.
} 
later also justice of the peace and postmaster. Asaph was also closely tied to Western Reserve College, founded a few miles away in Hudson shortly after his arrival. In a mid-1820s ceremony celebrating the erection of that Congregational institution's first permanent building, college officials interred into the cornerstone a hymn Asaph Whittlesey had composed for the occasion. ${ }^{75}$

It is unclear exactly what level of emotional closeness the Whittlesey brothers shared, but one bond that cemented their interests by the early 1830 s, apart from attachment to the college, was an unbending loyalty to the American Colonization Society. Most respectable Reserve men, including Giddings, were colonizationists at this time, although few were as devoted to the cause as the Whittlesey brothers. Throughout the 1830s, both men donated money to the ACS and also funneled offerings from other Reserve sources to the national headquarters. Elisha Whittlesey became especially active in the society, which he joined in 1823. President of his local branch, he also rose quickly to prominence in the national chapter, becoming a delegate, executive committee member, vice-president, and occasional stand-in for the president in leading meetings. According to one early scholar, Whittlesey and Henry Clay were the two "most influential" colonizationists in the West. In 1827, Whittlesey and his friend Jonathan Sloane persuaded Henry Clay to make the keynote speech at the national ACS annual meeting. ${ }^{76}$

The ACS sought the wholesale relocation and Christianization of free blacks and the goodwill of Southern slaveholders. It held special appeal for many

\footnotetext{
${ }^{75}$ Carroll Cutler, A History of Western Reserve College: during its first half-century 1826-1876 (Cleveland: Crocker's Publishing House, 1876), 26; and Western Reserve and Northern Ohio Historical Society, Ninth Annual Meeting, May, 1877 (Cleveland: Western Reserve Historical Society, 1877), 407-409.

76 Thomas D. Matijasic, "Whig Support for African Colonization: Ohio as a Test Case," Mid-America:66:2 (1981), 79-91; Early Lee Fox, The American Colonization Society 1817-1840 (Baltimore: Johns Hopkins Press, 1919), 94. The names of both Whittleseys_but especially Elisha-appear throughout the journal published by the ACS. See The African Repository and Colonial Journal, Vols. 9-16, for the period 1833-1840.
} 
Ohioans in the 1820 s, lately becoming more hostile to waves of free blacks then moving into the border state. Ohio's Black Codes failed to deter immigration as significantly as lawmakers had hoped. Never very large, the free black population in Ohio nonetheless burgeoned from around three hundred in 1800 to nearly 10,000 by 1830 . The Quaker-founded town of Salem, only a few miles distant from Whittlesey's Canfield home, numbered thirty formerly enslaved black families by 1830 . Concerned Ohioans such as Whittlesey had turned with mounting interest to the ACS, founding local chapters across the state. ${ }^{77}$

Whittlesey believed that blacks could never live freely in the United States because of the "excitement, commotion, or opposition," that would result. Social and cultural harmony required diligent protection. Because racism was so firmly entrenched in American society, he reasoned, freed slaves would become "dangerous alike to the property and repose" of all. He may have theorized in national terms, but for Whittlesey and many other Ohioans, the threat was real, observable, and existed in their own back yards. ${ }^{78}$

Events in the early 1830 s raised a good deal of regional concern. The antiMasonic disruptions were just resolving when trouble began in Hudson at Western Reserve College. Some faculty there began openly promoting abolitionism in lectures, newspaper articles, and through the spread of related materials, including William Lloyd Garrison's antislavery paper, The Liberator. This set the trustees and most supporters of the college, dedicated colonizationists, on edge. Responding favorably to the abolition message, some student leaders in the college colonization society, including Deacon Sutliff's son Milton, agitated for the group to disband. Criticism of the colonization movement

${ }^{77}$ Ellen Eslinger, "The Evolution of Racial Politics in Early Ohio," in The Center of a Great Empire: The Ohio Country in the Early Republic, ed. Andrew R. L. Cayton and Stuart D.Hobbs (Athens, Ohio: Ohio University Press, 2005), 92; and Middleton, 70 and 90.

${ }^{78}$ Davison, 141-142. 
increased significantly nationwide after Garrison's 1832 publication of a fiery treatise, Thoughts of African Colonization. Reserve colonizationists rankled at implications they wanted Christian character. Even Elisha Whittlesey stepped into the fray at the college, claiming to a friend that he elicited agreement from one abolitionist professor that the success of that cause would ultimately "destroy the union and the constitution." ${ }^{79}$

The Whittleseys watched warily as abolitionists from the college attempted to sway Asaph's hometown of nearby Tallmadge also to their cause. Asaph noted in July, 1833, that recently Tallmadge had been "abundantly favored" with "addresses [and] lectures" from abolitionists from the faculty or administration at Western Reserve College. Elisha concurred: "abolitionist missionaries" had targeted the town directly for their "fanaticism." The Whittlesey brothers were unwilling that the abolitionist onslaught in Tallmadge go unanswered, however. ${ }^{80}$

Asaph apparently had a hand in arranging speakers for the town's annual Fourth of July celebration-always a major event in Reserve communities-for the roster's two speakers that day were both relatives. Brother and sitting congressman Elisha Whittlesey spoke on the topic of colonization-for over three hours. Asaph reports in the ACS national journal that the audience of over three hundred listened with "great attention" to Elisha Whittlesey's address. Afterward, two abolitionist professors from Western Reserve College, there "restively" monitoring the speech, announced that one of them would give an address later

${ }^{79}$ A useful history of the Western Reserve College is Carroll Cutler, A History of Western Reserve College: during its first half-century 1826-1876. First-hand accounts of some of the brouhaha taking place there in the early 1830s appears in Liberator issues of that time frame. A very telling inside source of the general atmosphere among the students occurs in the letters of Milton Sutliff to his brothers during this period, found in the Sutliff Family Papers, Sutliff Museum. For the dust-up between Professor Beriah Green and Elisha Whittlesey, see Elisha Whittlesey to Richard Fenn, 6 July 1833, Elisha Whittlesey Papers, WRHS. For Garrison's anticolonization treatise, see Thoughts on African Colonization, or an Impartial Exhibition of Doctrines, Principles and Purposes of the American Colonization Society, together with the Resolutions, Addresses and Remonstrances of Free People of Color (Boston: Garrison and Knapp, 1832).

${ }^{80}$ African Repository and Colonial Journal Vol. 9; and Elisha Whittlesey to Richard Fenn, 6 July 1833, Elisha Whittlesey Papers, WRHS. 
that day. That lecture, says Asaph, "consisted solely in animadversions" of his brother's speech and so disgusted listeners that the "larger part" of the audience left well before the presentation ended. ${ }^{81}$

Asaph Whittlesey crowed that abolitionism in the area had only cost the Tallmadge colonization society a handful of adherents, which a recent increase of around seventy new members had more than offset. Although an abolition society recently formed at the college boasted over fifty members, Whittlesey triumphantly reported that most of them were women, children, and students of the college. Besides, some of those students, as well as members of the abolition society affiliated with Western Reserve College, registered their names that July fourth with both societies. ${ }^{82}$

Indeed, there was no foregone conclusion on the Reserve at this time that support for abolition mandated departure from a colonization society. For a time, abolitionist Western Reserve College students debated whether to resign from their colonization society. At a regional convention held in Cleveland, some concerned men wondered if they could form a blended abolition and colonization society. ${ }^{83}$

Nonetheless, Reserve abolitionism had a good deal of momentum and continued to progress steadily. Antislavery societies appeared in even the tiniest hamlets and soon they had abolition literature in the hands of people all across the Reserve. Local abolitionists answered a call in 1833 to form a national

\footnotetext{
${ }^{81}$ African Repository and Colonial Journal Vol. 9. At a similar event in nearby Elyria on this same date, a "respectful" audience of four hundred followed an all-day debate over the best solution to slavery. See Griffiths, 95-100.

${ }^{82}$ African Repository and Colonial Journal Vol. 9.

${ }^{83}$ Milton Sutliff to Flavel Sutliff, 13 June 1833 and 30 May 1834, Sutliff Family Papers, Sutliff Museum.
} 
antislavery society, and two years later also had a significant presence at the birth of the state society, as well.

One of the most influential groups that formed in the region was the Ashtabula County Female Antislavery Society, which organized in the fall of 1835. Its constitution supported the total abolition of slavery and immediate emancipation of slaves, peacefully attained by spreading information and Christian sympathy while concurrently promoting the religious, moral, and intellectual improvement of blacks. By 1838, the prolific organization boasted hundreds of members and had hired a male agent and generated eight auxiliary groups. $^{84}$

Two prominent leaders of this organization were Betsey Cowles of the Austinburg Cowles family and Joshua Giddings's wife, Laura. A charter member in 1835, Laura Giddings was responsible for adding the names of many Jefferson women to the group's roster. Such visible activism must have drawn the notice of conservative Whittlesey, who disapproved of women claiming ever-larger shares in the public discourse. It probably also explains why the abolitionist evangelist Theodore Weld stayed for a time in the Giddings home that same fall. Weld was lecturing his way through Ohio promoting immediate abolition and leaving social turmoil in his wake. ${ }^{85}$

${ }^{84}$ Donna Marie DeBlasio, "Her Own Society: The Life and Times of Betsy Mix Cowles, 1810-1876" (Ph.D. diss., Kent State University, 1980), 55-58. Extant records of the Ashtabula County Female Anti-Slavery Society are at the Western Reserve Historical Society and consist of a memorandum book which lists members, offices, resolutions, and some other minor data. Additional information on Reserve women's abolitionist activities is found in the Betsey Mix Cowles Papers at the Kent State University Library, mainly in the form of correspondence directed to Betsey Cowles.

${ }^{85}$ Davison, 79; Volpe, "Weld's Antislavery Mission" ; DeBlasio, 55-58; Letters of Theodore Dwight Weld, Angelina Grimke Weld, and Sarah Grimke, 1822-1844 Vol. 2, Gilbert H. Barnes and Dwight L. Dumond, Eds., (Gloucester, Massachusetts: Peter Smith, 1965), 879; Robert Abzug, Passionate Liberator: Theodore Dwight Weld and the Dilemma of Reform (New York: Oxford University Press, 1980), 124 and 136; and Stewart, 2730 . 
Some scholarly debate exists regarding the source of Giddings's abolitionist impulse, especially pertaining to the significance of Weld's role. The potential influence of Giddings's wife is never mentioned, but it seems unlikely Laura Giddings became a regional antislavery leader without her husband's tacit approval. Normally, antislavery women on the Reserve whose husbands did not approve of their joining abolition societies apparently declined becoming members, albeit reluctantly. Moreover, Giddings was fairly autocratic when it came to the conduct of household members-even grown children-during this period, and Laura seemed to concentrate her activities fairly close to home and among women she knew. On the other hand, the wives from the two neighboring Jefferson families to which the Giddingses were closest joined the same antislavery society as Laura Giddings, and neither husband was an abolitionist at the time. In fact, one husband remained a leader in the local colonization society for over a year. One reason women abolitionists became the topic of such debate over their proper sphere was that they played such an early and visible role in the movement. Despite their relative religious conservatism, it is likely that the Giddings household was in a period of ideological transition, and that Laura-like the two neighbor women, one of whom was her sister-encouraged the change to antislavery belief. With so many close associates already passionate about the burgeoning antislavery movement, the eventual adherence of Giddings and his wife to the cause seems rather natural. ${ }^{86}$

The year or two preceding the 1835 establishment of the Ashtabula County Female Antislavery Society had been an unsettling one for many on the Reserve, and it appears to have been a period of some transition for Joshua Giddings. In 1834, he and Whittlesey continued regular communications-still mainly about politics. Some confidential letters flew between them in the summer

${ }^{86}$ On Laura Giddings's devotion to her husband, see Memorial of the Pioneer Women of the Western Reserve Vol. 1, Gertrude Van Rensselaer Wickham, Ed., (Cleveland: Cleveland Centennial Commission, 1896), 47. Any liberalizing influences radical abolitionists of Giddings's later acquaintance might have on him remained at this time several years into the future. 
as they cleared up the issue of whether the district's anti-Jacksoniansbeginning to identify themselves with the Whig label-would again rally behind Whittlesey as a single candidate. Whittlesey confessed to Giddings his preference for retirement, but left it up to Giddings and his friends to ascertain what was best for the district. This put Giddings in a sticky situation, given his position as acknowledged heir-apparent to Whittlesey's seat and his ready admission that he was poised to run for the seat if Whittlesey declined to run for re-election. Some misunderstanding resulted from this exchange when Whittlesey misread Giddings's prediction of how the various anti-Jacksonian factions would align, which led to a slightly defensive exchange. Nonetheless, they ironed out the confusion with the usual reassurances of affection and goodwill.

That same summer of 1834 , Giddings was still an active promoter of colonization. Perhaps he even proudly distributed the pamphlet version of his mentor's 1833 Tallmadge colonization speech, which had proven extremely popular among colonizationists throughout the country, at his local July fourth celebration. Giddings and Hendry both attended the annual meeting of the Ashtabula County Colonization Society held that day. Members pondered the problem that now confronted them: "unwearied efforts" to "prostrate "the ACS by "erroneously representing" its views. Given the present crisis, they declared it their "imperious duty" to come to the society's defense. At that meeting Giddings seconded two resolutions, clearly also formulated in response to the antislavery movement gearing up all around them. The first resolution confirmed the members' "unabated confidence" in the ACS. The second proposed that a committee of three members should prepare a report to consist of the "solution of some objections" to the ACS or "should set forth some advantage." 87

\footnotetext{
${ }^{87}$ Ashtabula Sentinel, 12 July 1834.
} 
That same day the Ashtabula County Antislavery Society-a males-only organization-held their own annual meeting, their first. At this Austinburg event another Giddings friend, Henry Cowles, presided over a gathering of members also concerned about their organizational reputation. Resolution five passed that evening asserted rather defensively "[W]e altogether disclaim all anti-union designs and influence, fully believing that our measures and objects are the only possible hope for the permanent peace and union of our republic, and that they have no tendency to promote disunion." Resolution one declared it "highly important to exert a mild and persuasive influence"-language that members no doubt hoped would calm fears of their friends and neighbors who belonged to the county colonization society meeting nearby. Obviously feeling under some condemnation from the other side, the antislavery society also averred that they "must regard the Colonization Society as taking unchristian and unjustifiable ground when it censures all other efforts for abolishing slavery and asserts that slaves must not be emancipated without being immediately sent to Africa." ${ }^{88}$

So there they were: two groups of leading Ashtabula County men firing ideological volleys at each other through their organizational cannons by way of resolutions passed at annual meetings held on the same day. The memberships of these two groups represented friends now separated from friends, a father opposed to his son, and neighbors for whom the topic of resolving slavery had become increasingly tense. Fortunately for Giddings, assignment to the colonization group's committee tasked with answering objections to the ACS, or determining its advantages, fit perfectly with his particular approach to problem solving. It is unclear whether the committee ever delivered a report to the society-or even completed it, for that matter. However, if Giddings did the project as assigned, he would have commenced with the mammoth fact-

\footnotetext{
${ }^{88}$ Ashtabula Sentinel, 19 July 1834.
} 
gathering that was his habit, and it is interesting that no record of Giddings's active membership in a colonization society exists beyond this period.

Shortly later, in the fall of 1834 , Giddings and Whittlesey exchanged letters briefly. Giddings said acquaintances were worried about Whittlesey, concerned that "incessant labors" might ruin his health. Mainly, however, Giddings had business matters to discuss. Whittlesey had been on a very short list of men being considered for an important post with Ohio's largest financial institution. Giddings asked to be told of the eventual outcome immediately, as Whittlesey's congressional seat would then need to be filled. Riding unspoken atop this conversation was the issue of when Giddings might finally have his chance to fill Whittlesey's congressional seat. ${ }^{89}$

Whittlesey did not receive the appointment. However, something marks this exchange as unusual: it was apparently followed by a long silence. In fact, after this apparently routine exchange in late 1834 there is no evidence that Giddings and Whittlesey communicated again for over a year. In January, 1836, Giddings wrote Whittlesey requesting that he secure him a $\$ 20,000$ loan for a business venture, assuring him it would only increase the obligation Giddings felt for Whittlesey. However, by then Giddings must have noticed Whittlesey pulling back from their old level of political intimacy. He may have suspected Whittlesey was becoming a little paranoid over whom to trust. Who could blame him, given Whittlesey's leadership in the ACS, tensions over abolitionism on the Reserve, and the fact that Giddings was friendly with some of those evangelical enthusiasts who had come out early as abolitionist leaders? ${ }^{90}$

Giddings could not know in late 1834, when he and Whittlesey discussed the future course of Whittlesey's career, that so much time would elapse before

89 Joshua Giddings to Elisha Whittlesey, 8 November 1834, Elisha Whittlesey Papers, WRHS.

90 Joshua Giddings to Elisha Whittlesey, 27 January 1836, Elisha Whittlesey Papers, WRHS. 
they touched base regarding politics again. By the following spring, however, Giddings was truly miserable, despite the fact that his investments were by then making him a wealthy man-on paper, at least. In fact, within a year he would decide he was rich enough to retire entirely from the practice of law. In early 1835 , however, for some reason Giddings endured the worst season of "hypo" he had experienced up to this time-or would for some time after. Perhaps it relates to having his hopes at filling Whittlesey's seat recently dashed again, but that is simply not clear. In any case, this is the juncture at which he sought relief at Saratoga Springs, putting on a droll mask for Ben Wade while contemplating morosely whether he would live to finish his planned trip in a letter to his son.

Whether feeling better or not, Giddings was back in Ohio by summer, and it is then that he collaborated with Hendry, Cowles, and others in their projected revival for Trumbull County's major community. Something made these men want to promote a special period of Christian love and fellowship at this particular time. One possibility is that it relates to the strain the continuing debate over slavery had placed on relationships in their circle and across the region.

The antislavery disputes on the Reserve had disrupted all manner of social bonds. Among those men accustomed to functioning together at the head of regional affairs, taking the side of either colonization or abolition could now mean enduring attacks on their character. Often, those assaults came from other respected men, even if sometimes delivered indirectly through organizational resolutions. Enduring the inevitable distancing this necessarily produced in circles formerly marked by cooperation had to strain the bonds of masculine consanguinity. For two years, men among the friendly acquaintances of Giddings had steadily peeled off from colonizationism in favor of abolitionism. Henry Cowles and two Sutliff brothers—Levi and Milton—emerged as early leaders in 
the antislavery movement, even assisting at the late 1833 Philadelphia convention called to create the American Antislavery Society. ${ }^{91}$

As Giddings worked with friends on revival plans in the summer of 1835, master revivalist Charles Finney was newly arrived at Oberlin College, preparing to join fellow abolitionists at the fledgling Congregational institution as their professor of theology. Among students expected that fall were a number of young men from Lane College in Cincinnati. The so-called Lane Rebels had left Lane College when their antislavery activism drew the ire of college trustees. Led by fellow student Theodore Weld, they had stopped in Zanesville on their way to Oberlin to help found the Ohio Antislavery Society. A number of men Giddings knew from the Reserve played prominent roles there. In fact, Henry Cowles, the same Congregational pastor Giddings and Hendry enlisted only weeks later to cooperate at the proposed revival, drafted the constitution the OASS adopted and revivalist Charles Finney took an early role in the state society. ${ }^{92}$

Not everyone in the group planning the revival at Warren was an abolitionist in the summer of 1835 . For example, Hendry was a leader in the Ashtabula County Colonization Society, and remained so for around two years more. The status of some men named as possible collaborators is uncertain. Nonetheless, the fact that the committee included leaders from the two opposing movements begs the question of what exactly was going on in the minds of this group of men. It is possible this venture represented an effort to bind men in religious union in response to-perhaps even in defiance of-events threatening to coax them apart. Still, the normal function of revivals was not to serve as vehicles of private affirmation, but to convince as wide an audience as possible

\footnotetext{
${ }^{91}$ Liberator, 21 December 1833.

92 Liberator, 9 May 1835.
} 
to reflect, repent, and of course to convert or recommit. ${ }^{93}$ For two years, the tensions over slavery had muddied the waters of general goodwill and cooperation familiar to Giddings and his cohort of men used to guiding the Reserve. Perhaps this was an attempt to reclaim something they all felt slipping away.

If the revival Giddings and his team planned for Warren actually took place in that community, there is no record of it. They did say finding a location would be difficult. However, just six weeks after Giddings and Hendry wrote their letter to Levi Sutliff, a revival did occur in a Trumbull County town just outside Warren. In fact, Kinsman was the home of Levi Sutliff's equally religious brother-in-law and its church was a branch of the Sutliff's church in Vernon, sharing in the rotating services of the Sutliff's pastor, Harvey Coe. Although Finney apparently did not assist in leading the revival preaching, one of the revivalist Foote brothers did. Lucius Foote had close ties to the Congregational church at Jefferson, serving for a short time as pastor there in the 1830s. After attending the Kinsman revival for several days, an unnamed reporter described the event just witnessed for the Hudson Observer:

The people of God had assembled to plead for the outpouring of the spirit. Brother Lucius Foote was in attendance, through whom the Word 'which is the power of God unto salvation' was dispensed. The salvation of God descended freely . . . . The meeting was rendered solemn an awful by a sense of God's presence .... On the last day of the holy convocation, more than one hundred and fifty presented themselves as those who proposed to walk in

\footnotetext{
${ }^{93}$ The seminal work on the social function of revivals is Paul Johnson, A Shopkeeper's Millennium: Society and Revivals in Rochester, New York, 1815-1837 (New York: Hill and Wang, 2004). Johnson downplays the most obvious possible function of religious revivals, which was as true expressions of religious enthusiasm. Instead, he promotes more strongly that they functioned as a social control mechanism for a recently atomized and unruly work force. While Giddings and his closest religious associates occasionally hired help, they were not in occupations that required them to do so very often, and rarely mention it-certainly not in the context of the revivals. On the other hand, Giddings and some of his associates were particularly concerned that men with whom they associated, closely or otherwise, swear off liquor, indication that at least in that capacity they did wish to assert their vision of society on the general Reserve population.
} 
newness of life; but who until now had neglected to obey the gracious call of the gospel. ${ }^{94}$

Unfortunately, it is unclear what the ad hoc planning committee-some prominent abolitionists and at least one colonization leader-hoped would be the fallout of their proposed revival. It is also not clear whether Giddings was still suffering so severely from his depressive illness when he, Hendry, and a few others cooked up their clandestine revival plan. Although it must have happened in this general time frame, it also remains uncertain at what point Joshua and Laura Giddings finally embraced antislavery-or whether they even did so together. However, by the time of the September, 1835, Kinsman revival, the Giddingses were either already abolitionists or preparing to heed the sacred call to work "immediately" for slavery's end. Given that Laura Giddings was apparently among several leading lights in the founding only a month later of the Ashtabula County Female Antislavery Society, she was probably already an abolitionist, and her husband, as well. That same month, antislavery evangelist Theodore Weld stayed for a time in the Giddings home, using it briefly as a base from which to energize and expand abolitionism in their vicinity. ${ }^{95}$

\footnotetext{
${ }^{94}$ Ohio Observer, 17 September 1835.

95 The supposed role of Theodore Weld in converting people on the Reserve to abolitionism is considerably overblown. In fact, Giddings supposedly recalled that that it was two of Weld's footsoldiers-known as "the seventy"-who "revolutionized his district." See Oberlin Jubilee, 76. Reserve people already knew of Weld's remarkable oratorical talents from earlier visits to the area as a lecturer for the manual school movement. As an antislavery lecturer, Weld's habit was to visit areas where abolitionism already had a significant foot-hold, whenever possible, which was certainly true of the Reserve. What Weld did, in keeping with his training as a revivalist, was get people in the audience to come forward and act. In other words, without diminishing Weld's remarkable oratorical ability and grasp of important facts on slavery, the most important effect of Weld's lecture tour on the Western Reserve was probably motivating his audiences to form local abolition societies, which they did in droves during and after Weld's tour. Credit must also accrue to the many other antislavery lecturing agents-officially sponsored or independently motivated-who roamed the Reserve at this general time period. In the case of Giddings, the near-concurrence of Weld's visit with Giddings's turn to antislavery has led to the oft-repeated mythology that Weld "converted" Giddings to abolitionism. The more likely scenario is that contact with the Cowles and Sutliff families-both early converts to antislavery activism-influenced the Giddingses. In fact, the women in those families were as active as the men in fighting slavery. It is quite possible that Laura Giddings converted to antislavery through Betsey Cowles and then Joshua followed suit. On the significance of women in the abolition movement, with some references to conditions on the Reserve, see Stacey Robertston, Hearts Beating for Liberty: Women Abolitionists in the Old Northwest (Chapel Hill: University of North Carolina Press, 2010) and Julie Roy Jeffrey, The Great Silent Army of Abolitionism: Ordinary Women in the Antislavery Movement (Chapel Hill: University of North Carolina Press, 1998).
} 
Some confirmation that Joshua Giddings did indeed embrace abolitionism in this general time frame exists in the fact that he was elected a manager of the Ohio Antislavery Society at its first annual meeting several months later. This implies that delegates there felt Giddings had already proven he was reliably loyal to the cause, someone they trusted to help oversee the movement. Actually, Laura Giddings's society requested that she attend the Granville event as their delegate, but she rarely traveled long distances and no evidence exists that she made an exception in this instance. ${ }^{96}$

\section{Betrayed?}

By the time of the April, 1836, Ohio Anti-slavery Society meeting in Granville, Giddings had retired from his law practice and dissolved his partnership with Ben Wade. For one thing, he was wondering if the routine of life at home contributed to the recent worsening of his health problems. For another, he felt a real affinity for land speculation-one observer described him as "enterprising"-and decided to concentrate his professional energies that direction. Consequently, the month before the Granville convention Giddings worked land deals nearby in Toledo, but a short time afterward was managing affairs in New York City. ${ }^{97}$

Friends in Giddings's circle may have suspected one other possible reason Giddings dissolved his practice at this particular time, however: he was preparing to finally claim Whittlesey's congressional seat. Whittlesey had told political allies over the winter of his definite intention to retire and re-confirmed it in a letter to Giddings in February. Giddings closed his practice early enough in

\footnotetext{
${ }^{96}$ Robert Price, "The Ohio Anti-slavery Convention of 1836," Ohio History 45:2 (April 1936), 182. Note that Charles Finney also held office as a vice-president in the OASS at this time.

${ }^{97}$ Milton Sutliff to Flavel Sutliff, 4 May 1836, Sutliff Family Papers, Sutliff Museum.
} 
1836 that winning the upcoming fall election would not have left many loose ends to wrap up, if his election did indeed come to pass. Arriving home from Washington in early July for the summer break, Whittlesey sent the official notice of his intention to retire to a local newspaper editor with instructions that when Whittlesey's friends gave the go-ahead, he should publish it. This time Whittlesey seemed determined to go through with declining to run. ${ }^{98}$

Shortly after, however, Giddings discovered that Whittlesey had done a complete turnaround and declared himself once again a candidate for reelection-only this time without Giddings's advance knowledge. Giddings was stunned and crushed, but not because he had thought that his time to run for Whittlesey's seat had finally come. The appearance of things left Giddings feeling Whittlesey had completely bypassed him as a political confidante-the role he had played so prominently for many years past. ${ }^{99}$

Whittlesey defended his decision. Friends had persuaded him that their Whig allies from Ashtabula and Geauga counties were not likely to agree on a single candidate-unless it be Whittlesey. For the first time since Whittlesey's first election to Congress fourteen years earlier, he planned his course without Giddings's guidance. Even worse, this time he did so without even Giddings's knowledge.

Complicating matters, Giddings discovered some weeks later that his beloved mentor had not just grown away from him; he was convinced Whittlesey had also betrayed him. Friends confirmed to Giddings that while contemplating his course, Whittlesey had privately derided to them Giddings's chances to win

\footnotetext{
98 The Giddings-Whittlesey debate over Whittlesey's actions is best pieced together from the following: Elisha Whittlesey to Joshua Giddings, 15 August 1836 and 29 January 1837; and Joshua Giddings to Elisha Whittlesey, 22 January and 29 March 1837, Elisha Whittlesey Papers, WRHS.

${ }^{99}$ Stewart touches briefly on the Whittlesey-Giddings disagreement. See Stewart, 17.
} 
the seat. Whittlesey claimed the men on the Reserve might not unify around a Giddings candidacy, even though Giddings was the congressman's heirapparent. Worse yet, Whittlesey claimed the Jacksonian candidate might defeat Giddings if he ran. ${ }^{100}$

Giddings had assumed his relationship with Whittlesey was based on complete honesty and trust, one that, in his words, "requires frankness on both sides." Giddings's recent letter to Whittlesey asking that he arrange a loan for him had betrayed no apparent change in how Giddings felt about Whittlesey. For many years, they had marked important letters "confidential" and occasionally one asked the other to destroy a particularly secretive one after reading it. Their correspondence affirmed a singular level of affection, loyalty, and trust. On the other hand, Giddings knew that when Jonathan Sloane first aligned with the Antimasons some years earlier, Sloane claimed his close friend Whittlesey had betrayed an implied promise to step aside and let Sloane run for his congressional post. It was such a sore point with Sloane that his camp used it as a public campaign issue. Ironically, it was Whittlesey who had then informed Giddings of Sloane's charges. Even more amazing, Whittlesey had once instructed Giddings how to assess the kind of betrayal he was now struggling to comprehend. A man whose associates knowingly refused to dissuade him from an ill-advised political run was, in Whittlesey's words, "deceived by pretended friends." Blind faith in his mentor had kept Giddings from seeing that Whittlesey's loyalty to Giddings had recently faded. ${ }^{101}$

As was his normal response when confronted with unpleasant truths about friends, Giddings did nothing. More precisely, he stewed privately over the

\footnotetext{
100 Whittlesey's use of gossip to aid political strategy may have reflected his experience in Washington, where gossip was part of the accepted national political culture in the early republic. See Joanne B. Freeman, Affairs of Honor: National Politics in the New Republic (New Haven: Yale University Press, 2001), Chapter Two.

101 Joshua Giddings to Elisha Whittlesey, 21 July 1834, Elisha Whittlesey Papers, WRHS; Elisha Whittlesey to Joshua Giddings, 16 September 1830, Joshua Giddings Papers, Maag; and Davison, 89.
} 
apparent betrayal for several months before finally deciding he had to know the truth. Still, he communicated only with Whittlesey. Giddings's first letter was short and direct:

Confidential. Dear Sir: I think in justice to my own feelings I ought to make the enquiry of you whether you said to Mr. Bloss . . . last fall . ... [t]hat it would have been impossible for me to have been elected if you had declined? . . . . Or whether you made the same representations to Mr. Griswold while at court? Believe me sir that the subject is truly an unpleasant one to my feelings but justice to you and myself requires me to make the inquiry. I am conscious that my friendship for you has never deserved from you any declaration that should impair the confidence which my friends have heretofore reposed in me. . . "102

Giddings could not imagine that he possibly deserved such treatment by a supposed friend. Whittlesey responded immediately, offended:

If I rightly comprehend you, you entertain the impression that I have assailed you and endeavored to lessen you in the esteem of the electors ... . I am sure your feelings cannot be more severely tried than mine are .... If my declarations are not to be taken in evidence, I appeal to my most intimate friends, from whom I have not disguised my feelings, whether I have not on all occasions expressed for you, the warmest friendship and the strongest attachment. $^{103}$

Unfortunately, Giddings had believed he was still numbered among Whittlesey's "most intimate friends," not simply the subject of their conversations.

The subject upset him, Giddings confessed to Whittlesey in letters exchanged over the next two months. Whittlesey's actions had negatively affected the younger man's "character," claimed Giddings, who sometimes equated his character with the public perception of it. Now other men might conclude that Whittlesey-in times past Giddings's likely champion—doubted

\footnotetext{
102 Joshua Giddings to Elisha Whittlesey, 22 January 1837, Elisha Whittlesey Papers, WRHS.

${ }^{103}$ Elisha Whittlesey to Joshua Giddings, 29 January 1837, Elisha Whittlesey Papers, WRHS.
} 
Giddings's political abilities. By damaging Giddings's reputation, Whittlesey had also violated his sense of communal identity. ${ }^{104}$

Equally upsetting was Whittlesey's letter defending his actions. A series of excuses contained therein defied the rhetorical logic with which he had taught Giddings to assess the merits of an argument. Giddings responded at length and laid out his case: Whittlesey's explanation made no sense. No wisdom existed in surveying those Geauga County Whigs whose support for Giddings was in doubt only after Whittlesey agreed to run again. Furthermore, why not seek guidance from men who actually lived in that part of the district? Most importantly, it strained all logic that Whittlesey changed his mind about running only thirty hours after claiming some inquiry should be made-and this without allowing even a single trial ballot. It all made Giddings realize how willing Whittlesey had been to be swayed away from Giddings, and that he could no longer trust the most important male figure of his adult life. ${ }^{105}$

Whittlesey 's actions, Giddings confessed honestly, led him to "doubt your candor." He added,

They awakened feelings of pain, mortification, and regret at what appeared to me the abuse of that unhesitating and entire confidence which I had ever reposed in you up to that period. Yet while laboring under those feelings and while all the excitement of this moment operated upon my mind I did not feel at liberty to state the facts to any person except yourself and up to this hour they have been confined to my breast.

\footnotetext{
104 Joshua Giddings to Elisha Whittlssey, 22 January and 27 March 1837, and 17 July 1828, Elisha Whittlesey Papers, WRHS. Joanne Freeman defines character, in the context of politics in the early republic, as "personality with a moral dimension, referring to the mixture of traits, vices, and virtues that determined a person's social worth." See Freeman, xx. Reputation, she claims, was central to the "personal form of politics" that characterized the era. Also see Meyers, 209-10. Nicole Etcheson notes the implications of forthrightness and maintaining a good public reputation to the political culture of upland southerners during this period in "Manliness and the Political Culture of the Old Northwest, 1790-1860," Journal of the Early Republic 15 (Spring 1995): 59-77.

105 Joshua Giddings to Elisha Whittlesey, 29 March 1837, Elisha Whittlesey Papers, WRHS.
} 
Admitting that since his initial "excitement," time had "dispelled all feelings," Giddings said he was left with mainly his ultimate judgment of the event to guide his response: "I regret that I cannot view it in a light more favorable to you than I do at present."106

How could he? Giddings said Whittlesey had "pledged" in February that he would not run again. While Giddings insisted it had not really mattered to him whether he ran or not, he did care tremendously that Whittlesey would knowingly commit "gross injustice to the feelings of a friend." Having placed "full credit and reliance" on Whittlesey's word, Giddings said that he later felt "misled and duped." "I should be glad to know," continued Giddings, ". . . whether if I had pursued the same course you think it would have resulted in our mutual respect for each other?" This was the real crux of the issue for Giddings: Did his mentor not think better of him? ${ }^{107}$

Nonetheless, Giddings said he was glad he had told no one of Whittlesey's behavior. Despite the fact that it had been "ungenerous and improper" for Whittlesey to argue the case regarding Giddings's potential candidacy without his defense, Giddings could not bear to damage Whittlesey's influence and reputation. Besides, if he was in any way wrong about Whittlesey, he "rejoiced" that he had told no one else. On the other hand, Giddings added that if he had followed Whittlesey's example, he would have been polling all their friends who agreed with Giddings and using their influence to convince Whittlesey of his error. Still, Giddings reminded Whittlesey of his many years of loyalty:

Considering you entitled to confidence, I have for at least sixteen years contributed my humble efforts to increase your well-earned reputation. Yet the same spirit of independence which binds me to

\footnotetext{
${ }^{106}$ Ibid.

${ }^{107}$ Ibid.
} 
do you justice forbids that I should silently suffer injustice at your hands.

Giddings reassured Whittlesey of his unending gratitude for Whittlesey's many favors and suggested that if Whittlesey felt wronged by Giddings's conclusions, they take the matter up before a neutral friend. ${ }^{108}$

There is no evidence the two men argued their case before an ad hoc "judge." Giddings knew, however, that his future would not be served by closing the door on seeking further reconciliation with Whittlesey. He recognized that Whittlesey's goodwill would be invaluable if he finally got the chance to stand for nomination. While Giddings was certain Whittlesey would outwardly support whoever received the Whig nomination, Giddings had also just witnessed the destructive potential of background negotiations and knew he could ill afford to have Whittlesey as an outright enemy.

Although it never entered their discussions openly, Giddings had to suspect-probably he knew-the growing distance between their individual views on slavery had entered the equation. For one thing, at least one of the men to whom Whittlesey had confessed his doubts about Giddings's ability to win the election was also a regional colonization leader. Giddings knew this, and probably had his own suspicions regarding the context in which that conversation occurred.

It is also interesting that Whittlesey began to doubt the wisdom of Giddings's nomination only weeks after Giddings's appointment to office in the state antislavery society. Moreover, Whittlesey's promise to Giddings had been made before that event. Giddings's appointment as a manager in the OASS signaled Giddings was broadening his antislavery outreach. As a result, there

${ }^{108}$ Ibid. 
they now stood: the mentor, a current congressman and national ACS leader, opposite the protégé and political heir apparent, apparently also now a rising star in abolitionism-the very existence of which was anathema to Whittlesey. Knowing this, Giddings would also recognize the wisdom of not bringing this particular topic up to Whittlesey.

In addition, Whigs in Geauga County-where Whittlesey was told support for Giddings was most in doubt-were notoriously suspicious not only that Ashtabula County Whigs wanted political dominance, but also that abolitionists in Whig ranks might try to gain the upper hand in district affairs. Reserve inhabitants observed abolitionism exploding late in 1835 and throughout 1836. In fact, by the end of that year, the tiny Reserve portion of Ohio boasted half the total abolition societies in the state. Antislavery agents and orators roamed the region in greater numbers than ever, meeting resistance regularly. With abolitionism clearly riding a headwind, Reserve colonizationists such as Elisha Whittlesey grew even more wary and defensive. ${ }^{109}$

For a man who rarely spoke in Congress, Whittlesey spared few words when assailing abolitionists: Such "fanaticism" would "destroy the union and the Constitution." Believing this as strongly as he did, could Whittlesey entirely approve an abolitionist to represent the interests of his district in Congress? It is doubtful many-if any-of those friends who convinced Whittlesey so quickly to renege on his promise to retire were abolitionists. Eventually, Giddings assured Whittlesey he believed it had not been Whittlesey's initial purpose to do Giddings harm. However, this would not be last time famously mild-mannered Whittlesey let the antislavery convulsions of the mid-1830s carry him away. ${ }^{110}$

\footnotetext{
${ }^{109}$ Estimate of the Reserve's share of Ohio's approximately 200 societies is calculated using the Third Annual Report of the American Anti-Slavery Society (NY: William S. Dorr, 1836) and Anti-slavery societies in Ohio, excerpt, Underground Railroad Collection, Fourth Annual Report of the American Anti-Slavery Society (NY, 1837), accessed online at http://ohsweb.ohiohistory.org.

${ }^{110}$ Davison, 143; and Joshua Giddings to Elisha Whittlesey, 27 March 1837, Elisha Whittlesey Papers, WRHS.
} 


\section{The Robinson Affair}

Giddings and Whittlesey remained connected by Whig loyalties, and for a while yet they also still had a partnership in some land deals. In other words, circumstances demanded that they attempt to cooperate harmoniously and reliably. However, the dismay the two men felt over Whittlesey's political misstep was soon magnified when they saw banks tightening access to the cash investors like themselves needed to cover their obligations. Before long, a devastating depression had sunk the entire nation into financial despair-a situation sure to add strain to even the best of masculine relationships.

The Panic of 1837 developed when a run of demands for specie payment failed, causing banks across the country to collapse. Fortunes and jobs disappeared, men wandered aimlessly, and riots erupted. Evangelical reformers redoubled their efforts to eradicate national sins and pave the way to national millennial glory. Whittlesey had actually begun to worry in 1836 that signs pointed to an end of the speculative bubble that some men appeared to think would never burst. Soon, the complicated web of speculative land investments of Whittlesey, Giddings, and several partners began to unravel as creditors called for payment on loans. Whittlesey suffered a major financial setback, but Giddings barely skirted bankruptcy. By the time their business dealings finally resolved, their only contact was as political colleagues, nothing more. ${ }^{111}$

\footnotetext{
${ }^{111}$ On the social effects of the panic see Scott A. Sandage, Born Losers: A History of Failure in America (Cambridge, MS: Harvard University Press, 2005) Chapter One; and Samuel Rezneck , "The Social History of an American Depression, 1837-1843," American History Review 40 (October 1934-July 1935): 662-687. Two standard works on the panic are Peter Temin, The Jacksonian Economy (New York: W. W. Norton and Company, 1969) and Reginald Charles McGrane, The Panic of 1837: Some Financial Problems of the Jacksonian Era (Chicago: University of Chicago Press, 1965). On Giddings and Whittlesey and the panic, see Davison, 127-133; and Stewart, 16.
} 
Despite the uncertainty posed by the financial crisis and regional conflict over slavery, for the most part, the friends of Giddings-including Whittleseyappeared to carry on their promotion of either abolition or colonization in respectable fashion. Unfortunately, some of their Reserve neighbors expressed themselves in less reasonable ways. Reserve towns experienced growing discord as abolitionists and colonizationists vied for supporters and antiabolitionists responded by obstructing antislavery lectures with intimidation or minor acts of violence.

Antislavery orators knew to expect such treatment. In fact, when Theodore Weld and some other Lane Rebels were newly arrived on the Reserve awaiting the opening of the next term at Oberlin College, Weld conducted a two-week training session for many of them in preparation for entering the antislavery lecture circuit. One lesson included instructions on removing tar stains. Clearly, they expected some anti-abolitionists would follow through with the threats to tarring and feathering that were their stock in trade. ${ }^{112}$

One of Weld's colleagues absorbing that lesson was Marius Robinson, who in early June, 1837, suffered one of those predicted assaults. He was in Berlin township, only ten miles from Whittlesey's residence, lecturing on abolition at the home of a local Quaker merchant, town leaders having denied access to the schoolhouse. According to Robinson, he presented his first lecture with the full knowledge that it was "in opposition to the well-known wishes of the nobility of Berlin." Leisure time spent the next evening with the host and his wife in their store ended when twelve local men appeared and violently wrestled Robinson into their custody. Robinson suffered a serious cut on a rack of garden scythes during the scuffle. During the struggle, the host's wife was not only roughed up, but also warned harshly that she was "acting very imprudently" and would be

112 Oberlin Jubilee, 68. 
remembered for it. Over the next several hours Robinson also endured dragging, beating, and eventually the coat of hot tar and feathers for which his training session with Weld had prepared him. The assailants finally drove him into Canfield and dumped him near the village center-not far from Elisha Whittlesey's home, it turns out. Robinson dragged himself from house to house until he found a family willing to help. After receiving treatment for his wounds and new clothes, he rested overnight and attended church the next daySunday-and spoke on the evils of slavery. ${ }^{113}$

Not long after, Robinson again attempted to lecture in Berlin. This time it was the local constable who interfered, come to deliver Robinson to answer for charges of disturbing the peace relating to the earlier incident. Berlin's "proslavery junta," as Robinson called them, hastily scheduled a hearing. The six witnesses pre-arranged against Robinson included the local postmaster, the town doctor, a lawyer with ties to a local land magnate, and a local religious lay leader. The men testified that Robinson's presence had indeed disrupted normal social relations. One stated, "We were a remarkable peaceful, brotherly neighborhood before he came among us preaching his abominable doctrine. Now all is changed. Families divided-father against son-brother against brother-hired men discharged." Another claimed Robinson had actually "bantered the people of Berlin by saying that all the tar and feathers in the world could not stop abolition." Largely staged to prevent Robinson from delivering

\footnotetext{
${ }^{113}$ What appears to be Robinson's original narrative plus some unattributed but related documents are in the Marius Robinson Papers, WRHS. Also see History of Trumbull and Mahoning Counties Vol. 2, 116-119; C. B. Galbreath, "Anti-slavery Movement in Columbiana County," Ohio Archeological and Historical Quarterly 30 (October 1921), 355-395; and Russel B. Nye, "Marius Robinson, A Forgotten Abolitionist Leader," Ohio Archeological and Historical Quarterly 55 (April-June 1946), 139-154. Berlin (now called Berlin Center), Ohio, sits near the southwest boundary of what is now Mahoning County, but was then Trumbull County, a short distance from the Quaker-founded town of Salem in Columbiana County.
} 
another lecture, the proceeding ended with Robinson's release, officials apparently satisfied that he felt duly warned to step carefully. ${ }^{114}$

All twelve men subsequently charged with Robinson's kidnapping and assault were known by his hosts and yet made no attempt to disguise their identities. Earlier the day of the attack, one of them even told an acquaintance he was hurrying off to attend an "abduction meeting." In truth, one remarkable feature of many anti-abolition mobs was the assumption that "gentlemen of property and standing" among or encouraging the throng would protect perpetrators from repercussions. A year earlier, Giddings and other attendees departing the OASS convention had encountered a mob commanded by Granville's town leaders, of that same supposedly "steady" New England ancestry as Giddings, carrying out plans recently hatched at their local colonization society meeting! The truly astonishing thing about the preliminary hearing finally held in rural Ohio regarding Robinson's assault, however, was that one of the lawyers there representing the attackers was the sitting United States congressman of that district. ${ }^{115}$

What many colonizationists perceived as an all-out offensive against the ACS by abolitionists threw some colonizationists off balance. By the time of the Robinson affair, Whittlesey was a recognized national ACS leader. That year he became a vice-president and also a member of the national board of directors on the petition of the Ohio society. Whittlesey's extensive knowledge of financial affairs made him a valuable asset to the ACS in view of the current panic; the

\footnotetext{
114 Liberator, 21 July 1837; and History of Trumbull and Mahoning Counties Vol. 2, 116-119.

${ }^{115}$ Liberator, 21 July 1837 . Abolitionists sometimes used the phrase "gentlemen men of property and standing" to characterize the men who mobbed them. The standard treatment of this topic is Leonard L. Richards, "Gentlemen of Property and Standing": Anti-Abolition Mobs in Jacksonian America (New York: Oxford University Press, 1971). On the Granville "riot," see Robert Price, "Further Notes on Granville's Anti-abolition Disturbances of 1836," Ohio History 45:4 (October 1936), 365-368.
} 
organization eventually asked him to help prepare an address to the entire country in an attempt to weather its present "financial embarrassment."116

Whittlesey did his best during this period to bolster the organization's beleaguered reputation. For example, he tried to answer the common charge that African colonization was unworkable in remarks published in the ACS journal. Whittlesey assured readers, "The problem which remained doubtful for some time whether a Colony could be established, whose capacity would enable it to receive any large portion of the black population of this country, is solved. Such a Colony is established." Nonetheless, despite Whittlesey's attempts to encourage the ACS rank and file, some clearly felt the society was losing its battle with abolitionists. Writing that same publication some months later, a "Gentleman in Ohio" bemoaned that Ohio colonizationists were "without unity of design, or concert of action, and in general are in apathy for want of a proper stimulus . . . . Had we a tithe of the abolition zeal, we might do wonders." Whittlesey himself occasionally lamented the relative dearth of colonization materials available to answer the large volume of abolition literature that circulated across the country. It appeared to some that the Reserve might be going over rapidly to the cause of abolition, and area colonizationists, including Whittlesey, teetered defensively. The warning of the anonymous Ohio "Gentleman"-that "opposition to abolition is not a good principle to actuate a Colonizationist"-came too late to keep Whittlesey from getting embroiled in the growing Robinson debacle. ${ }^{117}$

Actually, many observers thought such behavior out of character for Whittlesey. According to his biographer, Whittlesey's personal makeup included an "abhorrence of violence," and a strong preference for "conciliatory tactics." However, Whittlesey's elitist Federalist leanings also encouraged the view that established leaders such as he should guard the region from disruptive and

\footnotetext{
${ }^{116}$ African Repository and Colonial Journal, Vols. 13 and 14.

117 Ibid.
} 
potentially damaging influences, including the social leveling that Reserve abolitionists appeared to be promoting. Consequently, Whittlesey-similar to Robinson's Berlin opponents-faulted the region's abolitionists for provoking discord and social ferment. Regional abolitionists had their own complaints against colonizationists, however, questioning their devotion to God and to their Reserve neighbors. The rancor between Whittlesey and area abolitionists had been growing throughout the 1830s. "Quite generally criticized" at home for opposing abolitionists, he still held some appeal for them in Congress, where he presented petitions for the abolition of the slave trade in Washington D.C. Nonetheless, Whittlesey was convinced theirs was a dangerous path, noting in his nationally-circulated 1833 address that abolitionism would "destroy the Union and the Constitution." ${ }^{118}$

In the weeks immediately following the Robinson beating, the minds of many Reserve men were occupied with other problems. The 1801 Plan of Union, by which Congregationalists and Presbyterians had cooperated in the West, was dissolving. Many on the Reserve-where Union churches predominated-were quite distressed by the change. Some churches even resisted. Several "dismembered Presbyteries," for example, called meetings to denounce the dissolution action as unconstitutional and unrighteous and urged no changes in church organization or relations. In addition, the Panic of 1837 hit northern Ohio hard, given that access to cash had been a problem there even in the best of times. The weekend of the Robinson beating, Giddings and some other regional men were preoccupied with an emergency convention called to address the value of paper money in circulation and debtor-creditor relations in this "season of confusion and perplexity in all money transactions." Not long after this meeting - where he was placed on a committee to make a public report-

\footnotetext{
${ }^{118}$ Davison, 134-177; McFarland, 112; and Victor B. Howard, Conscience and Slavery: The Evangelistic Calvinistic Domestic Missions, 1837-1861 (Kent, Ohio: Kent State University Press, 1990), 15-16.
} 
Giddings was in the Detroit area working hard to salvage what he could of his own financial situation. ${ }^{119}$

As the summer progressed, however, word spread of the "gross and violent outrage" against Robinson. Some Reserve papers ran brief notices of the event, while at least one covered it in full by publishing a detailed narrative prepared by Robinson, in which he also named not only his attackers, but others in Berlin who opposed him, as well. William Lloyd Garrison's Liberator published not only some of the Robinson narrative, but described in another issue the subsequent arrest of Robinson for supposedly disturbing the peace. The story also made at least one national paper, the New York Evening Post. Some antislavery societies around the Reserve formed committees to gather the facts and report back to members. ${ }^{120}$

The dispute over abolition heated up so intensely over the summer of 1837 that the debate nearly took over the Ashtabula Sentinel. In the July 26 issue, for example, the editor noted that some news meant for that week had been deferred for now and he laid down ground rules for contributors to follow "so long as the abolition excitement holds out." One anti-abolitionist writing to the paper cautioned his sympathizers that "mob-law . . . has helped the very cause which they are trying to put down." Further, another warned, abolitionists appeared now intent on making abolition a political issue, something the South would surely not long abide. ${ }^{121}$

In truth, the Robinson issue had quickly become political. For one thing, it raised questions about the "bare exercise of the right of speech, in a country

\footnotetext{
119 Ohio Observer, 27 July 1837; and Ashtabula Sentinel, 2 June 1837.

${ }^{120}$ Ohio Observer, 21 July 1837; Liberator, 7 and 21 July 1837.(Garrison reprints portions from Free Discussion, a Lisbon, Ohio, paper and the New York Evening Post). Also see Ohio Observer, 20 July 1837. Robinson's narrative probably first appeared in The Aurora, 15 June 1837, a paper published in nearby Lisbon, Ohio.

${ }^{121}$ Ashtabula Sentinel, 9 June, 26 July, and 2 August 1837.
} 
boastful of its freedom," noted Garrison. Indeed, the language Robinson used to describe his opponents-"nobility" and "pro-slavery junta"-demonstrates he felt the spirit of the republic was violated not by abolitionists attempting to exercise their right of free speech, but by those who tried to prevent it. For another, some officials in the vicinity of the attack brazenly manipulated the system in an attempt to silence Robinson. Some of Robinson's opponents convinced a local lawyer to issue a state's warrant for his arrest for having disturbed the peace, upon which the local constable agreeably acted. Robinson rather quickly found himself facing an ad hoc hearing in front of several pre-arranged antagonistic witnesses and a local magistrate. By dragging this out over a two-day period the men managed to keep Robinson from speaking anywhere over the weekendone of their goals. However, they also demonstrated willingness to, as Robinson described it, "enact one of the most ridiculous farces that ever disgraced the theatre of professed justice." In other words, some citizens witnessed the normal rules of civic and legal conduct suffering at the hands of the very men whose job it was to enforce them. ${ }^{122}$

The Robinson matter also quickly colored the political contest being waged through the summer and fall for some county and state offices. Of particular interest to men on the Reserve was the office of Trumbull County prosecutor. Rumors swirled that the present prosecutor, Democrat William Knight, privately refused to bring Robinson's accused attackers before a grand jury, although he later denied the accusation in print. Alarms also rang when reports appeared that the "Berlin mobocrats" had queried Knight's Whig opponent regarding his willingness to prosecute the case. ${ }^{123}$

Both major parties were unnerved by the abolition excitement on the Reserve during this general period, and the 1837 Robinson criminal proceeding

\footnotetext{
122 Liberator, 7 and 21 July 1837.

123 J. Taylor to Flavel Sutliff, 9 September 1837, Sutliff Family Papers, Sutliff Museum.
} 
produced a "terrible quaking" in the region. Regional candidates for upcoming elections began maneuvering around the issue. One even lied about his abolition society membership to gain a nomination. In Trumbull County, both major parties apparently pursued an extra-legal policy of avoiding all abolitionists for nomination-"proscribed for opinion's sake," complained one. Overall, then, evidence in the Robinson case and the political climate surrounding it demonstrated that not only might abolitionists' civil rights be violated, but some Reserve inhabitants intended to deny them their legal rights, as well. ${ }^{124}$

The legal and political trouble brewing in Trumbull County that summer eventually pulled Whittlesey, the Sutliff family, and Giddings into its orbit before it was all resolved. Deacon Samuel Sutliff and local sons Levi, Milton, Flavel, and Calvin had all come out early for abolition, along with the wives of Samuel and Levi. Milton and Levi were involved in state and national antislavery affairs, as well. Milton finished his course at Western Reserve College during the conflict there over antislavery in the early 1830s, and for a time was an antislavery lecturing agent of the AAS. By 1837, he had also finished law training with Elisha Whittlesey and taken up practice in Trumbull County. It was fairly natural, then, that abolitionist Robert Taylor, the attorney set to represent Robinson's interest at the August preliminary hearing, brought Milton Sutliff on board as co-counsel. ${ }^{125}$

The exact role Giddings played is uncertain. Being close to the Sutliffs and seasoned in criminal law, he apparently joined Robinson's team later in preparation for the case actually going to trial. Although he may have been consulting early on in the background, there is no evidence he attended the August preliminary hearing in Ellsworth, just outside Berlin. ${ }^{126}$

\footnotetext{
124 Ibid.; and Marius Robinson to Emily Robinson, 6 December 1837, Marius Robinson Papers, WRHS.

${ }^{125}$ Biographical fragment, Sutliff Family Papers, Sutliff Museum; and Charles Williams, History of Trumbull and Mahoning Counties Vol. 2, 178-81.

${ }^{126}$ History of Trumbull and Mahoning Counties Vol.2, 108. While only one source plainly links Giddings to the Robinson case, the fact that around this time Giddings apparently drew closer to the Sutliff family, taking Flavel
} 
Giddings's longtime mentor was not only there, however, but he gave such an uncharacteristic and impassioned performance that it set tongues wagging. The description of the hearing varies depending upon who tells it, but it appears Whittlesey got carried away from his usual restrained nature. Whittlesey became annoyed when forced to sit through what he viewed as a one-hour abolition lecture passing for an opening statement by Robinson's counsel. Once Whittlesey finally spoke, it became clear that the crime he most wanted to try was not that of the twelve men who had attacked Robinson. In Whittlesey's mind, the real crime was what abolitionism was doing to the country, and it became clear that his determination was to put abolition on trial.

Whittlesey got his real chance on day two of the hearing. While crossexamining Robinson, Whittlesey managed to lead him into a logical dilemma whereby Robinson found himself in the unhappy predicament of choosing between dissolving the union and upholding the evil of slavery. Of course, Robinson, uncertain how he wound up at this point, hesitantly answered that he chose the former. Whittlesey was triumphant. This is what he had claimed all along: abolitionists were disloyal and could be viewed as outright treasonous. Later, apparently gathering momentum from "impassioned" spectators, Whittlesey proclaimed that if abolition discussions led to violence, then the result of those discussions must be met with force-war, if necessary. ${ }^{127}$

\footnotetext{
as his partner almost immediately after the hearing, fits with that being true. Helping to prepare the case for trial only after the preliminary hearing-and then settling before trial-means there remains no official record of Giddings's involvement.

${ }^{127}$ Information on events surrounding the hearing regarding the Robinson attack is pieced together from the following: Elisha Whittlesey to the Western Reserve Chronicle, 17 August and 6 September, 1837, and Elisha Whittlesey to J. W. Edwards, 14 September 1837, all Elisha Whittlesey Papers, WRHS; and Western Reserve Chronicle, 22 and 29 August 1837. Additionally, see materials in the Marius Robinson Papers, WRHS. Whittlesey was so convinced abolitionism would ruin the country that several months later he defended the burning of a new abolition hall in Philadelphia. According to Whittlesey, the decision to destroy the building was made "coolly and deliberately," the men who carried it out were not just from the lower rank, and everything was done "quietly and orderly." Elisha Whittlesey to Polly Whittlesey, 20 May 1838, Elisha Whittlesey Papers, WRHS.
} 
At least that is what Whittlesey claims he said. Others thought he got so carried away that he said abolitionists themselves must be put down with force, if necessary. In fact, when Whittlesey heard about the existence of the alternate version, he placed a notice in all the regional papers denying it. This led Taylor, lead attorney, to write the papers that he was the source of the other version, but that he had proof and stood by it. Whittlesey, of course, replied in kind. Later, sixteen of Whittlesey's friends-including some of the very Berlin leaders who had tried to harass Robinson out of action-published a statement backing Whittlesey's version.

A curious thing had happened. For all intents and purposes, public attention veered from the Robinson attack and potential political misdeeds surrounding it. Now, the center of attention was sitting United States Congressman Elisha Whittlesey and whether he had advocated that abolitionists be "put down." Ironically, the very lawyers who opposed Whittlesey at the hearing-Taylor, Sutliff, and apparently Giddings in the background-were all trained by Whittlesey. Moreover, Whittlesey had committed a serious error in his conduct, one he no doubt had warned these three former students to avoid. Whittlesey let his emotions color his presentation in such a way that it distracted from the issue at hand.

Whittlesey failed that day. The twelve accused men were bound over for trial. However, the case eventually settled out of court-perhaps neither side was eager to prolong the public debacle the case had turned into-and defendants each paid Robinson forty dollars. 
Given Giddings's penchant for smoothing out relations, he may have joined the team representing Robinson's interests with hopes of finding a way for Robinson to receive justice without further damaging Whig coherence. The fact that the case settled before going to trial lends some credence to that admittedly hypothetical supposition, and certainly once Robinson's twelve assailants were bound over for an actual criminal trial they might see settling served their own best interest. Years later, when Whittlesey's name came up in consideration for nomination for Ohio governor by the Whigs, recollections of his indiscreet entanglement with the Robinson affair led his colleagues to abandon the idea. ${ }^{128}$

In any case, for the most part Giddings stayed out of sight. His attendance at the preliminary hearing would have been unwise, anyway, given that he was still hoping for the nomination to Whittlesey's seat. The men representing both sides of the case were all strong Whigs from his district, and Giddings could not afford to get publicly identified with a heated Whig versus Whig dispute. However, what Giddings did not do is also instructive. Giddings did not join in the newspaper discussion that flew back and forth for several weeks over Whittlesey's character, even though for years past he was the most likely man to uphold it. On the other hand, although Giddings did not defend his mentor's character, there is no record he ever truly spoke ill of Whittlesey, anywhere or to anyone. Remarkably, he also apparently never mentioned the Robinson affair to Whittlesey—then, or ever.

Giddings's personal policy of not damaging other men's reputations-and his desire to win nomination for Whittlesey's seat-guided him to take the proverbial high road. Given the excitement in Whittlesey's life that summer, he may not have even noticed the quiet gesture Giddings made in submitting an

\footnotetext{
${ }^{128}$ History of Trumbull and Mahoning Counties Vol. 2, 108. On the Whigs' snub of Whittlesey regarding the governorship nomination see Letters of James Gillespie Birney, 1837-1857 Vol. 1, Dwight L. Dumond, Ed. (Gloucester, Massachusetts: Peter Smith, 1966), 536.
} 
ACS donation to the national office on behalf of a woman who normally did so through Whittlesey. Apparently, this time she gave the donation to Giddings, still linking the two men closely together in her mind. What Whittlesey probably did notice was that someone arranged that an article praising Whittlesey's record of public service appear in a Reserve newspaper, the type of task that used to fall to Giddings. If Whittlesey's past behavior is any indication, he may have even coaxed that gesture along. In any case, Whittlesey's plan for the Robinson hearing was to finally unveil the true character of abolitionism. Now, Whittlesey's reputation was also being weighed in the public mind. ${ }^{129}$

If the Robinson affair set Reserve inhabitants wondering how far abolitionists' opponents would go to silence them, the murder of Elijah Lovejoy directly on the heels of it raised true alarm. An antiabolitionist mob had attacked Lovejoy's Alton, Illinois, printing office only two months earlier, but that story raised no particular interest, given that newspapers received more stories about mob violence in the mid-1830s than editors were willing to print. However, the Robinson attack and Lovejoy murder suggested a more sinister pattern of resistance than the typical antiabolitionist demonstrations. Kidnapping, beating, and murder were more hateful crimes than throwing a few eggs or dumping a printing press in the river. ${ }^{130}$

Pursuant to a public call, the Ashtabula County Antislavery Society met in a day-long convention with concerned citizens from Ashtabula and Geauga counties. Resolutions passed that day demonstrated the heightened level of concern these Reserve inhabitants felt for their liberty, their civic voice, and their safety:

\footnotetext{
${ }^{129}$ African Repository and Colonial Journal Vol. 13.

${ }^{130}$ Editor of an antislavery newspaper, Lovejoy died when antiabolitionists mobbed his office on 7 November 1837. On the prevalence of mob violence in the mid-1830s, see Richards, Gentlemen of Property and Standing.
} 
Resolved, that ... [slavery's] evils are not confined to slaveholding districts; it is the direct and deadly foe of all liberty among us . . . . Resolved, that the spirit of mobs is most dangerous to the Commonwealth .... Resolved, that the spirit of slavery which recently burst its barriers at Alton, Illinois, if not abolished, will stifle the voice of the people in their right of petition-silence our statesmen in our legislative halls .... Resolved, that resolutions recently introduced in the Senate ... on the subject of the liberty of speech and the press, the right of citizens to meet peaceably, and petition Congress on any subject they may consider a grievance. . . merit our most cordial approbation ..."

To be sure they got the point of that last resolution, the group voted to send a copy to their representatives in Washington, one of whom was Elisha Whittlesey. ${ }^{131}$

The Jefferson Antislavery Society also called a special meeting, separated by only a day from the county society's convention. Giddings had been president of this organization for at least a year. By now, its membership included Flavel Sutliff, living in Jefferson and working with Giddings, and Samuel Hendry, who finally left the ACS and now proclaimed that " . . . members of this republic . . . are loudly called upon . . . to protect the civil and religious institutions of the country from the violence of an overheated and infuriated populace." One man present noted the "deep solemnity" characterizing members' faces. Sutliff spoke on Lovejoy's martyrdom to the cause of liberty, a man become "obnoxious to the rabble and nought but his blood could give satisfaction." Giddings seconded Sutliff's motion upon the "inalienable rights of man," and followed with a speech delivered "with much feeling upon the willful, the uncalled for violation of those rights." Events of the past several months demonstrated that abolitionists exercising their constitutional rights

\footnotetext{
${ }^{131}$ Ashtabula Sentinel, 27 January 1838. The other representative in Washington receiving a copy of the last resolution was Senator Thomas Morris, whose recent presentation of similar sentiments to the Senate was praised in the Ashtabula meeting and in the full-length version of the resolution. His Democratic colleagues back in Ohio were not as thrilled with Morris and he was not back in Washington representing Ohio the following term.
} 
sometimes did so under serious threat to their lives. This realization drew Giddings and his antislavery Reserve friends more closely together and focused their attention on the dangers even free northerners faced when confronted with the "spirit of slavery."132

\section{The Mentor}

One result of the Robinson affair was that Giddings drew even closer to the Sutliffs, for shortly after the hearing he took on Flavel as his legal partner. It appears their attachment grew rather naturally, as colleagues addressed the firm as "Giddings and Sutliff" long before either one thought to draw up any official documentation of the partnership. Having just finalized his training, Flavel probably helped older brother Milton and Giddings that fall as they strategized the Robinson case for possible trial. As another of Deacon Sutliff's several sons, Flavel certainly came from a family Giddings knew well and trusted. He was also serious, outwardly moral, and a devoted abolitionist. As Giddings got up his nerve quietly to join the Robinson team after the preliminary hearing, he probably soon took comfort in knowing he had a professional companion who shared his antislavery enthusiasm and was likely to look up to Giddings rather than question whether he could ever represent the will of his district. ${ }^{133}$

Giddings's choice of Ben Wade for his first partner in 1831 had not turned out entirely to his liking. For a time, the somewhat younger Wade was so reticent that he contented himself in the office while Giddings did court duty. If Giddings

\footnotetext{
${ }^{132}$ Ashtabula Sentinel, 3 February 1838.

133 David Tod to Giddings and Sutliff, 17 January 1837 (1838), Joshua Giddings Papers, Maag. The date on this letter is incorrect, probably owing to the newness of the year and old habit of writing the year as 1837 . When Giddings received it, however, he apparently wrote the correct date of 17 January 1838 on the outside edge before filing. It remains uncertain exactly how long the partnership had been in place before January, 1838 . Giddings and Sutliff apparently did not draw up an official notification for the court until an official asked for it much later. Flavel Sutliff, "Memorandum of an agreement," 7 August 1838, Sutliff Family Papers, Sutliff Museum.
} 
encouraged him onto the public stage at that time, Wade certainly resisted. Theirs was an odd pairing in other ways. Even before Giddings's full-on embrace of religious enthusiasm, it appears he had not advertised his departure from the beliefs of his pious parents. Wade, on the other hand, was well known as a scoffer of religion. Although Wade had rather forward views on race equality, he refused to join any of the Reserve antislavery societies that flourished from the mid-1830s on, probably to keep his political options unencumbered. Nicknamed "Bluff Ben," he also exhibited a rough manner and used rude and even profane language, not willing to work as hard as Giddings to offset the evidence of inauspicious beginnings. ${ }^{134}$

However, like Giddings, Wade was a rough-hewn poor farm lad turned lawyer who trained with Elisha Whittlesey. The two became known to locals as great friends. For a time, Wade also watched over Giddings's growing family in his occasional absences-not really an onerous task, given that the law office stood adjacent the Giddings home. Giddings recognized that Wade's rough exterior masked a man also capable of tenderness. On one occasion, Wade confessed to Giddings, "Sir, if my heart is capable of friendship I feel that sentiment for you more than for any person under heaven." ${ }^{135}$

\footnotetext{
${ }^{134}$ Wade's forward views on race equality later made him stand out as an antebellum Ohio senator and also during the 1860 s as a Radical Republican in the U. S. Senate, although he maintained that racial prejudice possibly made colonization a preferred route for free blacks. Unfortunately, no recent biography of Wade exists. The usual source is Hans L. Trefousse, Benjamin Franklin Wade, Radical Republican from Ohio (New York: Twayne, 1963). In 1886 A. G. Riddle wrote a hagiographic biography, The Life of Benjamin F. Wade (Cleveland: Williams), but the slightly expanded version published in 1888 has additional information on both Wade and Giddings. Riddle presents Wade as a man of towering character and independence, never consciously pursuing his own advantage, certainly never self-serving, the opposite of the stereotypical politician that Giddings was, always seeking popularity and trying to win "by management." Remarkably, Riddle claims Giddings "admired and trusted Wade," who "always knew what [Giddings] was really doing." See pages 392393 of the 1888 version. If Riddle accurately represents Wade's feelings toward Giddings, it appears the two men retained an outward friendship even as each one felt the other was ultimately a self-seeking politician undeserving of personal trust. W. D. Howells recalls Wade's reputation for using profanity in Years of My Youth (New York: Harper and Brothers, 1916) 108.

${ }^{135}$ Benjamin Wade to Joshua Giddings, 6 October 1837; and Joshua Giddings to Joseph Addison Giddings, 13 February 1840, both from Joshua Giddings Papers, Maag.
} 
However, Giddings began to think Wade might be correct in wondering if he was capable of true friendship. At some point, Giddings decided he did not entirely trust Ben Wade. He apparently kept his feelings secret, however, only admitting it finally to his near-grown sons after they figured out Wade's selfserving tendencies and sought to warn their father. No longer "charmed" or "deceived," he now felt that Wade had "no principle that he would not sacrifice for his interest, no friend whom he would not sacrifice for his own preferment." In truth, Giddings never got over the fact that "friend Wade" had actually worked against Giddings, secretly promoting his own consideration to fill Whittlesey's old seat in Washington. Giddings also believed Wade never entirely paid his share of jointly-incurred debts. ${ }^{136}$ Nonetheless, Giddings outwardly maintained a friendly relationship with Wade and proceeded with caution.

Giddings once explained his philosophy toward masculine relationships to his sons: "Make all your friends so far as courteous, civil, and gentlemanly deportment will do it," under normal circumstances speaking no ill of even the vice-prone among them. In fact, Giddings masked his feelings about Wade so well that Wade's manner toward Giddings remained casually intimate. Wade addressed him as "Gid" and at one point breezily asked for a hundred-dollar loan. Wade was possibly unaware, then, that Giddings's partnering with Flavel Sutliff signified just how cautious Giddings had become regarding whom he could truly trust. $^{137}$

The Robinson affair and pairing of Giddings with Flavel Sutliff both transpired while the fortunes of Giddings and Whittlesey plummeted alongside the value of their joint-investment real estate as the result of the Panic of 1837.

\footnotetext{
136 Joshua Giddings to Joseph Addison Giddings, 8 and 13 February, 1840, Joshua Giddings Papers, Maag; and Joseph Addison Giddings to George Julian, 21 May 1877, George W. Julian Papers, ISL.

137 Joshua Giddings to Joseph Addison Giddings, 13 February 1840, Joshua Giddings Papers, Maag; and Upton, 575.
} 
Climbing back from near bankruptcy and disillusioned by Whittlesey's crushing betrayal, Giddings now had few remaining markers by which men commonly measured success. Consequently, he counted himself fortunate that in 1838, Whittlesey finally retired. Sadly, this time Giddings had to ask Whittlesey if he might finally verify "reports in circulation" to that effect-stark testimony to the distance now separating them. ${ }^{138}$

Giddings won the special mid-term election to Whittlesey's vacant Washington seat, disproving his mentor's prediction and bolstering his confidence in the rightness of his political aspirations-and competence to speak on behalf of his district. Of course, Whittlesey supported the Whig ticket, but Giddings feared low enthusiasm on the part of Trumbull County Whigs and asked Whittlesey to encourage a more systematized effort. To be sure, district Whigs were in turmoil over abolition, but other issues, such as the role of banking in the wake of the panic, also demanded attention. Consequently, Whig voting results in 1838 for state and national offices mirrored those of 1836, even though Giddings insisted that antislavery discord was already coloring factional alignments within the party. ${ }^{139}$

Giddings's political future still had been uncertain when he formed his partnership with Flavel Sutliff, but their arrangement separated the men's affairs enough that Giddings could control his own obligations-and later manage to be in Washington a good portion of each year. The terms were, however, also remarkably generous, testimony to the fondness Giddings felt for the Sutliff family. Sutliff was to have complete use of the office and law books for free and

\footnotetext{
138 Joshua Giddings to Elisha Whittlesey, 23 June 1838, Elisha Whittlesey Papers, WRHS. Actually, Whittlesey considered retiring in both 1837 and in 1838, and on each occasions Giddings was forced to write Whittlesey to confirm or deny circulating rumors.

${ }^{139}$ Joshua Giddings to Elisha Whittlesey, 10 September 1838, Elisha Whittlesey Papers, WRHS; Vernon L. Volpe, "The Ohio Election of 1838: A Study in the Historical Method?" Ohio History 95 (Summer-Autumn 1986): 85100) and "Benjamin Wade's Strange Defeat," Ohio History 97 (Summer-Autumn 1987): 122-132.
} 
apparently keep all revenues he generated while attached to the esteemed Giddings name. In return, Giddings apparently only asked-at least officiallythat Sutliff complete some business still unresolved from Giddings's old partnership with Wade. ${ }^{140}$ Even after Whittlesey's supposed betrayal, Giddings vowed never to forget what his generous aid early in Giddings's career had meant to him. That example always before him, Giddings now launched what he assumed was his own turn at playing magnanimous professional mentor.

For fifteen years, Whittlesey and Giddings had maneuvered skillfully through periods when potential challengers or nascent parties threatened Whittlesey's tenure. To be sure, the turmoil over slavery that swept the region in the 1830s had certainly complicated Whig coherence and Giddings's relationship with Whittlesey. Still, Giddings believed their circle of political allies could eventually iron out disruptions enough to cooperate. They had done it for years despite individual ambitions, religious differences, local jealousies, and even major disruptions to general harmony, such as the Robinson affair.

So, in spite of his rocky path to Whittlesey's congressional seat, Giddings proceeded in large measure as Whittlesey's example had taught him, hoping to help launch Flavel as Whittlesey had aided Giddings's rise. Partly, this meant managing regional Whig affairs through a small number of trusted local friends, mainly Flavel Sutliff, neighbor Samuel Hendry, and to a lesser degree Milton Sutliff. To be sure, Giddings stayed in contact with Whittlesey, but his former mentor did not function as a confidential political advisor.

That role was apparently shared in large part by Samuel Hendry and Flavel Sutliff. In fact, early on Flavel almost seamlessly became to Giddings what Giddings had been to Whittlesey: assistant, advisor, sounding board, and

\footnotetext{
140 "Memorandum of an Agreement," handwritten copy by Flavel Sutliff dated 7 August 1838, Sutliff Family
} Papers, Sutliff Museum. 
unofficial mouthpiece. From Washington, Giddings tried to manage Whig affairs through Flavel, directing him on men and measures and navigating potential Whig divisions. Often Giddings insisted that his background maneuvering remain confidential, and even sometimes insisted letters be burned after reading. As Giddings got his bearings in Congress and his excitement over coming onto the national stage burgeoned, near frantic letters pondered to Flavel whether-and when-Giddings should try to outsmart the House ban on discussing slavery. ${ }^{141}$

Stationed in Giddings's law office in the side yard of the Giddings residence, Flavel Sutliff was not only in near daily contact with Giddings's family, but the neighboring Hendry family, as well, and Giddings commonly instructed all of them to compare letters to get the full report of his activities. In effect, Flavel Sutliff functioned like a de facto member of the Giddings family. Giddings instructed Flavel to "step to the house" occasionally to give messages to family members. Giddings's office always seemed to have a couple of law students, even in his absence, and Flavel was expected to oversee their training and examination. In fact, Giddings's two older sons also studied some under Flavel's watchful eye. When Laura Giddings complained to her husband that the two older sons were reading novels, it was Flavel he expected to help set them straight. At one point, Giddings praised Flavel for making one of his sons quit a job in a nearby town when the arrangement appeared detrimental. By all appearances then, Flavel was Giddings's beloved friend and trusted confidante, roles Giddings had eagerly played to Whittlesey in the past. ${ }^{142}$

\footnotetext{
${ }^{141}$ Joshua Giddings to Flavel Sutliff, 24 December 1838, Sutliff Family Papers, Sutliff Museum.

142 Unfortunately, exactly how Giddings's relationship to Hendry functioned in unclear; however, he was as close to Giddings as any man on the Reserve by the mid-1830s. No letters exchanged between the two men remain, although Giddings mentions that they existed. The Samuel Hendry Papers in the WRHS provide a small window into Hendry's world, but do not contain letters written to or from Giddings. Joshua Giddings to Flavel Sutliff, 26 April 1840, 23 April 1840 and Flavel Sutliff to Levi Sutliff, 11 July 1840; both from the Sutliff Family Letters, Sutliff Museum. Giddings occasionally laid out for his children the precise appropriate order of personal responsibility: God, family, friends, community, nation, world.
} 
From Giddings's early perspective, Flavel was an excellent man to have stationed in his office, near his family, and functioning as his personal and political contact at home. Sutliff was a fervent reformer, much in demand throughout the region for temperance lectures. He was a dedicated opponent of slavery and a firm Whig, even accepting their nomination to run for prosecuting attorney in Ashtabula County not long after partnering with Giddings. Moreover, Flavel came from one of the most religious and moral families of Giddings's acquaintance, and his personal habits appealed to Giddings immensely. Of course he avoided alcohol and tobacco, but he also, like Giddings, believed morning exercise, limited diet, water therapy, and avoidance of medicinal drugs were part of the "strictest surveillance" necessary to preserve health. So highly did Giddings esteem Flavel that he told his son there was "no man within my acquaintance whose general character is so worthy of imitation." ${ }^{143}$

Flavel's brother Milton could probably take much of the credit for some of what Giddings admired so much in his young assistant. As Flavel grew to real adulthood, Milton embraced the role of directing and guiding his slightly younger brother's development, something he possibly did because of their father's limited education. After leaving for college, Milton wrote remarkably long letters to two brothers still at home, lecturing, moralizing, directing, criticizing, instructing, evaluating, and generally acting as if responsible for marshalling them onto paths of success. Milton was a "man of great self-control" who directed his brothers to follow a strict and regulated daily regimen of study. Neither Flavel nor brother Calvin apparently thought to challenge their older brother's assertiveness. Milton was proving himself a talented student of literature, language, and philosophy and became a respected lawyer shortly after finishing college. His reform credentials were also impeccable. Milton had helped spearhead the movement away from colonization among Western Reserve College students and after

\footnotetext{
${ }^{143}$ Joshua Giddings to Laura Giddings, 9 December 1838 and Joshua Giddings to Comfort Pease Giddings, 26 April 1840; both Joshua Giddings Papers, Maag.
} 
graduation served as a self-funded lecturing agent with the American AntiSlavery Society. He and eldest brother Levi were actually among the earliest actors in the budding state and national antislavery movements. Milton never shrank from the opportunity to debate a wrong idea or promote a right one. His was a daunting example to follow. ${ }^{144}$

Flavel was probably uncertain what to expect from this new arrangement with Giddings, who was functioning not only as a legal partner, but also a political mentor. Moreover, he now had Giddings and Milton both prodding and directing. Flavel cooperated with Giddings for the most part, but eventually confessed on the side that he disliked parts his situation in Jefferson. ${ }^{145}$

Adding to Flavel's discontent, a number of religious antislavery men in his closest circle were becoming disaffected with the Whigs, feeling taken for granted and even abused at the national, state, and sometimes even local levels. In fact, when antiabolitionist Reserve Whigs bolted in 1839 in protest for what they perceived as a ticket overly sympathetic to antislavery, Flavel's bid to become county prosecutor went down in unexpected defeat. Very gradually, a few antislavery men around the country began to noise interest in supporting separate nominations, especially for major offices such as president or governor. As the 1840s progressed, this halting trend turned into a minor groundswell on the Reserve, where some pious antislavery men dubbed themselves "Liberty" partisans and vowed never to vote for candidates who refused to oppose slavery. In fact, there was a great deal of discord on the Reserve over whether the Whigs' 1840 nomination of William Henry Harrison for president represented a token

\footnotetext{
${ }^{144}$ On Milton's involvement in events at Western Reserve College and as an antislavery lecturing agent, see his 1830s correspondence in the Sutliff Family Papers, Sutliff Museum, where also the best information on the Sutliff family appears. Also see History of Trumbull and Mahoning Counties Vol.2, 178-81.

${ }^{145}$ Flavel Sutliff to Levi Sutliff, 11 July 1840 , Sutliff Family Papers, Sutliff Musuem.
} 
gesture to antislavery men who had expected slaveholder Henry Clay to receive the bid. ${ }^{146}$

A frustrated Giddings watched as Flavel, Milton, and Levi Sutliff leaned the Liberty direction, as well as Woolsey Wells, another man with whom he had cooperated on the 1835 revival plan. Along with some other antislavery Whig colleagues of Giddings, these men became weary of all the criticism and general abuse they had taken from conservative Whigs, especially at the national level. Flavel inhabited an especially difficult situation, pulled opposite directions by Giddings and Flavel's two older brothers. Finally, Flavel confessed to Giddings in February of 1840 that he was leaving the Whigs for good.

It was not an easy thing to cross a devoted Whig. To fervent Whig partisans, expectations of loyalty took on almost sacred proportions. One observer claimed Whigs would rather "wade in hot lava up to their armpits" than defect, while another compared it instead to "plucking out the right eye." When Giddings formed his partnership with Flavel Sutliff, he took for granted that they shared his nearly unshakable Whig loyalty. Giddings instructed Flavel on managing potential regional divisions and guarding Giddings's political secrets. He even suggested Flavel work to get up a huge rally for Harrison, a candidate Flavel was not even sure he wholeheartedly supported! During much of the time they partnered, Giddings wrote Flavel confidential letters suggesting Flavel and others "discard this third party" some were trying to "get up" as some regional Whigs-Flavel's brothers included-debated how much longer they could stomach supporting any Whig candidate. ${ }^{147}$

\footnotetext{
${ }^{146}$ Vernon Volpe, Forlorn Hope of Freedom: The Liberty Party in the Old Northwest, 1838-1848 (Kent, Ohio: Kent State University Press, 1990) covers the tensions associated with the development of political antislavery, including those associated with the Reserve.

${ }^{147}$ Vernon Volpe, Forlorn Hope of Freedom, 40, and Volpe, "The Ohio Election of 1838," 91. Giddings was citing House colleague William Slade's concurrence with his own views regarding the "separate party." See Joshua Giddings to Flavel Sutliff, 3 December 1839, Sutliff Family Papers, Sutliff Museum.
} 
Giddings truly felt deflated by Flavel's apostasy from the Whig faith. He was "not angry," he assured Sutliff, but "disappointed." For one thing, Giddings insisted any time antislavery moved off purely "moral grounds" and became overtly political, problems resulted. In fact, Giddings claimed his Washington experience confirmed it after finding it difficult to appeal to House colleagues' consciences when political overtones colored their perceptions of his intentions. On a more personal level, however, in some measure Flavel's rejection of Whiggery marked a rejection of Giddings's presumptive and heavy-handed mentoring style. In fact, Flavel claimed that Giddings had exerted influence on his own abolitionism in a way that led Giddings to defend himself: "[l]t was never my intention that you should surrender your opinion nor do I now understand you to have done so." Mainly, however, Giddings knew the Liberty movement could only complicate his political life considerably. Now he faced potential opposition not only from the usual sources-factions built around regional rivals or antiabolition-but now might include pious antislavery men who had been his closest friends and confidantes. ${ }^{148}$

Softening the blow somewhat, however, was Flavel's explanation of changes he had been recently experiencing. Flavel was recommitting himself to his religious beliefs, or more precisely, finally embracing the beliefs with which he had been raised as his own. Giddings responded that he was "very grateful" that Sutliff shared this personal news and wished God's blessing on him. "[M]an is but a miserable ephemeral being if his existence be confined to this short life," Giddings added. ${ }^{149}$

Giddings's claims notwithstanding, Flavel apparently still struggled with issues of compromise, conscience, and moral consistency. He probably also

\footnotetext{
148 Joshua Giddings to Flavel Sutliff, 25 February 1840 (two letters), Sutliff Family Papers, Sutliff Museum.

149 Joshua Giddings to Flavel Sutliff, 7 and April 1840, Sutliff Family Papers, Sutliff Musuem.
} 
wearied of other men urging him whom to trust and how to think. At one point he pondered to Giddings how much exposure to the world was possible before the devoted Christian compromised his spiritual goals. Giddings replied, "There is nothing in religion according to my view opposed to a correct and diligent discharge of all the ordinary duties of life." In fact, he added, religion was "the great principle that should govern our moral, social, and political duties. . . . the foundation of all philosophy and the true expounder of the objects of life." As proof, Giddings pointed out the various religious meetings House members had and noted that the truly pious could exist consistently among them. However, earlier Giddings had also revealed some of the seamier side of politics by telling his sons the warnings about Ben Wade-whom Flavel knew and respectedshould probably be shared with Flavel. As Flavel observed the maneuverings and manipulations Giddings and others used to manage outward appearances, he could see the masks their system sometimes required them to wear and the compromises to consistency that appeared part and parcel of political success. ${ }^{150}$

Seeking a purer existence, Flavel moved his focus away from thinking about combinations of power and toward reforming man, the creature. $\mathrm{He}$ lectured some on temperance, but his burning passion became pursuing the body reforms made famous by Sylvester Graham. Popular among a small number of reformers, the Graham system mandated a strict, bland vegetarian diet and regulation of sexual activity. However, Graham's more devoted adherents also knew his Edenic vision was intended to eliminate the vices and unchecked passions that Americans generally agreed portended ruin to republics, so dependent upon virtuous citizens for their existence. An America fixated on striving and luxury would only decline "under the domination of an artificial and capricious appetite," Graham warned. Graham's most enthusiastic followers, such as Flavel became, could not miss noting that Graham also

150 Joshua Giddings to Flavel Sutliff, 26 April 1840, Sutliff Family Papers, Sutliff Museum. 
promoted his system to end human oppression, purify political parties seemingly always corrupt, and even produce something akin to millennial triumph, if their beliefs ran that direction. Here were goals already consistent with Flavel's value system, but this field of action was the one venue where he felt he could seize complete autonomy-his own body. ${ }^{151}$

The level of Flavel's adherence to Grahamism drew attention from family, friends, and even strangers. People trying the system wrote him about their experiences, sometimes asking him to share his collected reading materials. $\mathrm{He}$ received an invitation to teach at a nascent academy where dietary restrictions were a central component of the overall plan. Mostly, however, Flavel heard from family members grown worried that Flavel's extreme dietary "abstemiousness" was responsible for his now-emaciated frame and might portend his early demise.

Flavel may have become a mysterious transcendentalist of sorts, seeking special spiritual messages from the universe as he roamed unpredictably and slept in the open air, long-bearded and garbed in homespun robe and rope belt like some barefoot latter-day apostle. Eventually, he may have even heard the universe speaking to him in audible voice. At least this is the mythology kept alive by an 1873 novel set on the Reserve, penned by a regional lawyer and interweaving Reserve notables such as Giddings, Wade, and Sutliff quite prominently in the story. The claim therein is that the brilliant, young nonconformist especially sought out lawyers for discussion and debate, although they mostly avoided Sutliff, who was uncomfortably eccentric and perhaps insane. Indeed, the story emanating from the Giddings household some years

\footnotetext{
${ }^{151}$ Sylvester Graham, A Defense of the Graham System of Living, or Remarks on Diet and Regimen Dedicated to the Rising Generation (New York: W. Applegate, 1835.) The quoted phrase is taken from page 12. The usual scholarly source consulted on Grahamism is Stephen Nissenbaum, Sex, Diet, and Debility in Jacksonian America: Sylvester Graham and Health Reform (Chicago: Dorsey Press, 1998).
} 
later was that Flavel Sutliff, a young lawyer of brilliant promise, had affiliated with Giddings a brief two years before going insane. ${ }^{152}$

Truly a tragic figure, Flavel Sutliff was barely in his thirties when he died early in 1843, around two years after leaving Giddings's office. It is difficult to ascertain what ultimately caused his death, but certainly he was dangerously thin. A few months earlier he had suffered such a spell of high fever and serious general swelling that his family all offered their final goodbyes. Flavel was barely mentioned after his death in Sutliff family correspondence, but then neither was Levi's beloved young wife, Mary, whose lifestyle and mental condition had raised no particular questions before her death. Given the obscurity of the old novel in which Flavel Sutliff appears, what remains to keep Flavel's memory alive is mainly the story that came from the Giddings household, that Sutliff was his partner two years and went insane.

There is a good deal left out of what that truncated report implies, however. First, Flavel left Giddings's office well before his behavior and reputation caused anyone to question his sanity. Granted, his judgment in some areas seemed unnecessarily uncompromising, which worried those closest to him, but he had left Giddings's office before his behavior began to elicit serious apprehension. ${ }^{153}$

152 See A. G. Riddle, Bart Ridgeley: A Story of Northern Ohio (T. Nagar,Chennai (India): Tutis Digital Publishing, 2007). Although Riddle identifies the characters of Giddings, Wade, and other Reserve people by their real names, he barely disguises Flavel, calling him "Sartliff." Perhaps the unflattering nature of the suppositions about his mental state led Riddle to affect the non-disguise. Riddle, a Reserve inhabitant himself, later wrote a biography of Benjamin Wade. His representations of Giddings and Wade in Bart Ridgeley ring remarkably true, given comments others made about them. Whether he took more liberties with the character of "Sartliff" is uncertain. Riddle was himself a young Reserve lawyer and vibrant Whig during the period Giddings and Flavel Sutliff associated. Later, he was a successful attorney in Cleveland and Washington, D. C. Published in 1873, Bart Ridgeley was Riddle's first novel and reportedly was "widely read and favorably noticed as the best American novel of the year," although it is obscure now. See Pioneer and General History of Geauga County, with sketches of some of the Pioneers and Prominent Men (Burton, Ohio: Historical Society of Geauga County, 1880), 327-335.

${ }^{153}$ Nineteenth-century doctors did not agree on either the definition of insanity or its causes. Some believed it had both hereditary and environmental causes, the former probably making victims more susceptible to the latter. Some factors considered as possibly linking to insanity were idleness, bad luck, poverty or luxury, religious 
Eventually, however, they had real reason for concern, especially in the two years following his departure from Giddings. Flavel wandered on a long trip East without telling Milton, who worried that he was without adequate funds and contacted Giddings in Washington to see if he could help. Actually, Flavel made at least two trips East during this general time period, and trying to see Sylvester Graham in person was high on his travel agenda. Relatives continually fretted that he might soon die, given his emaciation and a constitution that had never been robust. Milton pled with him to see Graham for the "knave" he was. Graham's system had not fixed that reformer's own miserable health, and certainly even he expected none would pursue it to the extent Flavel now did. Moreover, how dare Graham publish a letter from Flavel praising the Graham system in his newsletter, editing out portions that might raise questions about its validity! ${ }^{154}$

Giddings, the Sutliffs, and in fact many on the Reserve were open to the many unusual religious or reform movements popular in antebellum America. Much like upstate New York's famed Burned-Over District, the Reserve was a seedbed of experimentation, and inhabitants grew used to neighbors embracing religious perfectionism, strict abstinence in diet or drink, manual labor schools, abolitionism, and later even Spiritualism. To be sure, the majority did not adhere or even perhaps approve, but they were used to the movements existing in their midst.

Yes, the Graham system advised the ingestion of wild foods in their natural state, avoidance of indoor air or restrictive clothing, even that men stop

excitement, sunstroke, atheism, death of a loved one, severe childhood disease, neglect of early physical training, social pressures or problems, and intemperance. See Carla Yanni, The Architecture of Madness: Insane Asylums in the United States (Minneapolis: University of Minnesota Press, 2007), 2-3.

154 Milton Sutliff to Flavel Sutliff, 22 September 1840 and 7 November 1841, Sutliff Family Papers, Sutliff Museum. 
shaving occasionally, and evidence hints that Flavel added those changes of habit to his regimen in an effort to achieve a state of health and awareness closest to that nature intended. Admittedly, Flavel believed in what he understood as the Graham system so completely that he refused to accept that his skeletonized frame signaled true danger. Perhaps he rationalized that it was to be expected, given that Graham also advised adherents to expect periods of decline before their health improved. ${ }^{155}$

The true state of Flavel Sutliff's mental condition as his demise grew near will remain a mystery, apparently. Nonetheless, as he wound down his affairs with Giddings, Flavel was apparently in his right mind. In fact, it was some time into their partnership when Giddings advised one son to "copy after [Flavel's] manner and his habits." Several questions arise. For one thing, no one knows who first broached the idea that Flavel leave, or why, despite sources that may imply otherwise. Certainly the remarkable level of political intimacy once shared by Flavel and Giddings gradually diminished after Flavel left the Whigs and it became clear he would not be persuaded otherwise. However, Flavel also had quietly grown unhappy with the time demands of his position and some of the burdens Giddings placed upon him, as well as the full-time practice of law. Nonetheless, it is obvious Giddings and Flavel truly cared for each other during their association and that Giddings, himself prone to devastating bouts of illness, sympathized with Flavel's health struggles.

\footnotetext{
${ }^{155}$ How is it that Flavel Sutliff, the young man Giddings loved and told his near-adult sons to model themselves after, for a time one of Giddings's most intimate political confidantes, has been relegated to obscurity? Partly, this is due to a lack of primary sources, or more correctly, to historians' lack of awareness that letters between Giddings and Flavel Sutliff existed. A very small number of letters in the Milton Sutliff Papers at the WRHS were actually written to Flavel, although the salutations are vague. A much larger number reside in the Sutliff Family Papers in the Sutliff Museum, although they are barely known and not officially prepared for scholarly use. Perhaps more influential to the historical record has been the early biography of Giddings written by son-in-law George Julian, who must have heard the details of Giddings's brief partnership with Sutliff from Giddings, or at least a close family member. Every historian who even mentions Flavel Sutliff in connection with Giddings repeats what Julian claims. Julian dismisses Flavel Sutliff as a promising young lawyer who had the briefest connection to Giddings before going insane. Couple that information with the dramatically tragic version of Flavel inhabiting the very popular 1873 Riddle novel, wherein he is described as living in an alternate mystical reality while rumors of insanity circulated, and it is no wonder Flavel Sutliff became marginalized, if he was mentioned at all.
} 
Flavel's life subsequent to his departure certainly functioned as a rejection of Giddings's mentorship_and his Whiggery. But it also signaled more than that, as Flavel, who may been an early leader in the Reserve's Liberty movement, soon become unreliable there, too. Eventually, he appeared to reject active political participation altogether while he concentrated on solving society's ills outside politics through the promotion of personal perfection. His particular path was one of rare elevation, however, one that none of his reform-oriented former colleagues or even his assertive older brother dared follow. Truth is, Flavel's life became a critique of all the ambitious men and their political organizations and their reform compromises. It was a protest Flavel Sutliff lived until the day he died, but it also did not motivate successful Reserve men who knew Flavel to correct misrepresentations about his sanity, if they existed. ${ }^{156}$

Among the men who fell from political intimacy with Giddings in the early 1840s were some of his closest friends, soon turned sometime political opponents as Liberty men. Although Giddings tried to maintain an outward level of friendship and cooperation, relations broke down in election years, even becoming bitter for a time. Lacking the level of trust he had formerly taken for granted, Giddings found himself struggling harder than he ever imagined possible to again locate, much less represent, a concentrated voice on the Western Reserve.

For Joshua Giddings, an ambitious man by all accounts, self-perception was inextricably bound up with the role he played in open view on the Reserve.

\footnotetext{
${ }^{156}$ It is possible Flavel Sutliff really did lose his grasp on sanity, but of course that is uncertain, as is whether his physical illness got severe enough to affect his mental coherence. Nonetheless, during his time with Giddings he apparently communicated logically and acquitted himself creditably in court. Unfortunately, most of what we know about Flavel comes from letters written to him, as only a few of those he wrote to others remain.
} 
In large measure, his success testified as much as anything to the fact that he had convinced other men there to let him function as he did. In a region populated mainly by migrants from the "land of steady habits," his were, even by those standards, especially industrious. Giddings built on that work ethic with a knack for fostering goodwill in most of his cooperative masculine relationships, even if some men occasionally grumbled that his role among them had become too prominent. And of course, he never forgot that other men had helped to launch his rise.

Leading men could not rest on their laurels, however, as others also constantly rose to prominence - or at least aspired to it. Moreover, Giddings's humble origins were well known to Reserve neighbors, so he was never exactly sure when he had accomplished enough to prove the legitimacy of his claim to a leadership role, despite his assertion that aristocratic attitudes carried no legitimacy in a republic of supposed equals. On the other hand, anyone could see that the same basic pool of prominent men generally filled leadership roles for the innumerable civic, religious, and benevolent endeavors underway as the newly populated Reserve grew into a settled society. So, rising to true significance on the Reserve meant breaking into that circle and expecting to serve in a variety of diverse capacities while doing so.

One key to Giddings's rapid rise was his early attachment to Elisha Whittlesey and his ability to become so useful to him just as Whittlesey left for Washington. This elevated Giddings in politics in their district. Since Whigs were so overwhelmingly dominant across his part of the Reserve, it effectually elevated Giddings in general, as well. In fact, despite Congressman Whittlesey's enjoyment of great popularity during his fifteen-year tenure, some men at home wondered if his confidante in Jefferson had garnered too much regional power. As the heir-apparent to Whittlesey's seat, Giddings did finally win election to Congress, but the growing rancor over slavery seriously complicated his political 
life. Unfortunately, it also strained relationships once taken for granted and challenged Giddings's ability to shepherd his own political assistant.

Giddings's mentorship style did not function as a silent critique of Elisha Whittlesey, despite the souring of their relationship. Structurally, their approaches to mentorship were remarkably similar, and Giddings at no point viewed his expectations of Flavel Sutliff as violations of his mentee's own civic voice. To see that possibility would have required Giddings to question whether he had subsumed his own independence to Whittlesey all those years he served Whittlesey's interests. His rejection of such notions was possible because Giddings truly viewed promoting Whittlesey's political interests as the complete equivalent of promoting his district's voice and influence. Certainly Giddings could not foresee that Flavel Sutliff would reject the Whigs and even eventually move the site of civil discourse from the body politic to the body proper.

Conversely, Giddings's antislavery did function as a silent critique of Whittlesey, silent because they never allowed their differences on that topic to enter overtly into their dealings. Still, they had that debate in other ways, primarily through the influence each managed to have on their Reserve cohort regarding antislavery. Americans who followed news reports of the conflicts among the colonization, antislavery, and antiabolition movements knew they represented challenges not only to individual rights to assemble or speak, but the right of groups to collectivize their civic voice, despite the dangers to national union others felt accompanied that exercise.

When that discourse colored district political relations, Giddings struggled to hold his Reserve Whigs together, Whittlesey having retired just in time to avoid the worst of the infighting. All political men on the Reserve-which is to say nearly all Reserve men-understood that any discussions occurring widely among them carried the potential to affect how they exercised their collective 
voice. In fact, it was something Giddings stressed as he tried to rein in political divisions over slavery: no man should be proscribed from office for his beliefs on that topic. "I have too long sought for union," Giddings wrote Flavel, to encourage those who "go for proscription." That message had meaning for antiabolitionists who would reject Giddings or other candidates for their antislavery beliefs. However, it also carried a plea to those Liberty men to whom Giddings had been so close, including the Sutliff brothers, that they not reject him for remaining a Whig. Tell Reserve men "your belief" I will not compromise in Congress, Giddings pled, but "shall go as far this year as I did last." 157 From Washington, Giddings perennially performed a precarious high wire act, trying to convince Reserve abolitionists that he went far enough, while assuring the general Reserve constituency he only went as far as Northern rights demanded.

Giddings had grown to political maturity on something he once called the "religion of politics." 158 For most in his anti-Jacksonian cohort, politics took on near-sacred proportions in its solemn mission of preventing Jackson or the Democrats from perverting the proper use of civic life. Giddings received a wakeup call when some of his closest friends, religious antislavery men, abandoned the Whigs for the Liberty movement. Most of these men had more deeply imbibed religion and reform as part of their earliest ideological sustenance. Consequently, they worried more about associating even tangentially with the sin of slavery than the catastrophic effects Giddings and other dedicated Whig partisans predicted could result from the Democratic dominance that threatened if antislavery men divided their votes.

\footnotetext{
157 Joshua Giddings to Flavel Sutliff, 22 February 1840, Milton Sutliff Papers, WRHS.

158 Joshua Giddings, draft of undated speech, George Julian Papers, ISL. This fragment may be related to a joint memorial Giddings made with John Quincy Adams in 1844 asserting Christian truths were foundational to the people's liberties. See "Joshua Giddings," entry in The Biographical Encyclopaedia of Ohio of the Nineteenth Century, Charles Robson, Ed. (Cincinnati: Galaxy Publishing, 1876).
} 
Giddings never doubted that being a man of true significance on the Reserve meant representing the voice of others in some way. This he did as a lawyer, political operative, organizational leader in benevolent or civic endeavors, revival planner, antislavery supporter, and finally as the elected representative from his Reserve district to Congress. Without doubt, however, he imagined his role to include shaping that voice, and the tension between the two imperatives is one he struggled to balance. Whittlesey and Giddings both wrote of ending their congressional careers earlier than they did, but hesitated when doing so might give the appearance that they had caved to pressure from others. They wanted their departure to be on their own terms and avoid the appearance of having been forced out by public opinion or admitting to the "correctness of the opposition." 159 Aspirant men's worries did not end when they secured leadership roles. Constant alertness to changing winds and potential falls from favor were necessary to avoid the perception of rejection by those whose interests they claimed to represent.

Giddings always thought the key to bringing his regional masculine cohort into agreement was the dissemination of knowledge-persuasion by pertinent facts. Toward that end, he published a series of essays in 1842 under the pseudonym "Pacificus," aimed at reuniting disaffected former Whigs who now identified as Liberty men. Their total focus on slavery was too narrow, warned pacifier Giddings: "our people" would not neglect their interests. He tried to

\footnotetext{
${ }^{159}$ The quote is from Joshua Giddings to Flavel Sutliff, 22 February 1840, Milton Sutliff Papers, WRHS. Some of the letters in the Milton Sutliff papers, addressed only to "sir" or "friend," are actually letters written to Flavel, apparently going into Milton's possession sometime after Flavel's death. Giddings's directions to the recipient are the best clues to determining that person's actual identity, which has been complicated by Flavel's correspondence remaining so obscure. Additional difficulties arise in dating Giddings's letters due to his handwriting and mode of abbreviating months. Consequently, errors occasionally exist in some archival finding aids. I always use the correct recipient and date as determined from the actual letter.
} 
convince them that to represent a constituency-to "concentrate their influence," in Giddings's words-it was necessary to really find their voice. ${ }^{160}$

Giddings once told a son on the verge of adulthood that achieving distinction actually took more than the "unflinching application" that he insisted was vital. Another component Giddings touted as necessary for aspiring men was some form of public recognition-and the bolder the circumstances that drew attention, the better. Making one's "debut," he called it. What good were a man's talents if no one took notice-especially in a world seemingly crawling with ambitious men? However, he also advised that the men most likely to lead also learned to watch and listen around other men and learn how each one functioned: "Be silent witnesses of the conduct of mankind." It was a skill a young and poor but ambitious Giddings had no choice but to cultivate, and enabled him to maneuver remarkably well through some rather striking challenges to masculine relationships. During the turbulent 1830 s and early $1840 \mathrm{~s}$, his commitment to religious belief, Whiggery, and benevolent reform firmed some of those attachments even as it strained others. ${ }^{161}$ To some, Giddings represented the quintessential politician-too often manipulating backstage and working his connections. True, without doubt. On the other hand, he also developed a keen sense of how the Reserve community of men functioned, and the necessity that they operate as often as possible together, the only way he could envision their voice sounding loudly enough for the new republic to hear.

${ }^{160}$ See Joshua R. Giddings, Pacificus, the Rights and Privileges of the Several States in Regard to Slavery (1842, digital reprints available through the Cornell University Library Digital Collections). The essays originally appeared serially in the Western Reserve Chronicle after the election of 1842.

161 Joshua Giddings to Joseph Addison Giddings, 10 January, 8 February, and 13 February 1840, Joshua Giddings Papers, Maag. Abolitionist and religious sentiments presented a potential roadblock to maintaining meaningful political influence in Congress, as well, so Giddings reconciled the necessity of political expediency with the demands of his conscience. James Brewer Stewart correctly observes that the congressman resolved this moral dilemma by rationalizing the importance of the Whig party in fulfilling his own reform agenda and cosmological vision. See Stewart, 43-4. 


\title{
CHAPTER 3: OSCAR LEARNARD AND THE
} BROTHERHOOD OF FRIENDS

\author{
A throng of generous hearted brothers, \\ Strong in friendship, high in aim, \\ Striving, with a manly valor, \\ To acquire an honest fame.
}

_- "Chevalier James H. Jerusalem" nee Oscar Learnard"

\begin{abstract}
When "Bleeding Kansas" veteran and pioneer Oscar Learnard died in 1911, one zealous eulogizer wrote: "He came to the territory and fought for freedom when God himself seemed dumb. He did a man's work in a man's way. . ." How Learnard came to his own understanding of pursuing life "in a man's way" is the subject of this study. ${ }^{3}$
\end{abstract}

${ }^{1}$ The University Regulator, April 1855, Oscar Learnard Papers, Kreitzberg Library, Norwich University, Northfield, Vermont.

2"Old Warrior Gone," The Daily Journal-World (Lawrence, Kansas), (date missing) November 1911. Oscar Learnard Papers, University of Kansas Spencer Research Library (hereafter UKSRL).

${ }^{3}$ On the expression of nineteenth-century Northern manhood see Anthony Rotundo, American Manhood: Transformations in Masculinity from the Revolution to the Modern Era (New York: Basic Books, 1993), Stuart Blumin, The Emergence of the Middle Class: Social Experience in the American City, 1760-1900 (Cambridge: Cambridge University Press, 1996), and J. A. Mangan and James Walvin, eds., Manliness and Morality: Middle-Class Masculinity in Britain and America 1800-1940 (Manchester: Manchester University Press, 1987.) All of these authors examine a cohort similar to Learnard in that they focus upon those men who reflected or sought what we now call middle-class status. The distinguishing character of southern manhood is explored in Bertram Wyatt-Brown, Southern Honor: Ethics and Behavior in the Old South (Oxford: Oxford University Press, 1982). David D. Gilmore, Manhood in the Making: Cultural Concepts of 
According to David Gilmore, manhood is the "approved way of being an adult male in any given society." Its "precious and elusive" quality, he notes, transcends "mere maleness" and represents in all cultures a "measure of belonging." ${ }^{4}$ As he entered adulthood, Learnard found that assurance of cohesion and cultural acceptance through close attachments to his father and an intimate coterie of male schoolmates. Codes of conduct formulated in that circle redounded to the understanding of all involved, a process that was probably repeated for other young men in countless variations across the antebellum North. Oscar and his closest male companions helped each other fashion acceptable boundaries for masculine expression within their circle of social acquaintances. However, they also created in Oscar a preference for functioning within a clearly delineated cohort of associates who shared a general agreement upon goals, providing that "measure of belonging" of which Gilmore writes. Safely ensconced within a circle of like-minded peers, Oscar typically rose to prominence, whether in the academy of his boyhood home, away at college, or fighting with the Free State men in Kansas in 1856.

Oscar Learnard was an old man when he mounted the podium to address the annual meeting of the Veterans of Fifty-Six club in September of 1910. Threatening weather had forced the gathering indoors, which would not have happened in 1856, according to one observer. Back then, storms posed "no terrors for men and women who . . . expect[ed] to see armed ruffians coming to slay, burn, and destroy." It had been 54 years since the notorious "Sack of Lawrence" that propelled Kansas Territory into the antebellum spotlight nationwide, however, and Learnard, like many there, was nearly eighty and

Masculinity (New Haven: Yale University Press, 1990) explores the nearly universal understanding of manhood as a special concept.

${ }^{4}$ Gilmore, 1 and 17.

"Was Big One: Annual Meeting of 56ers Yesterday at Learnard Hall," 15 September 1910. Oscar Learnard Papers, UKSRL. 
failing. This day, though, Learnard exhibited some of his old Yankee "go ahead," for he had come finally to set the record straight: John Brown, fellow son of New England, did not merit the recent sensational hagiography fraudulently posing as historical writing. The debate was not a new one in eastern Kansas or elsewhere, but when this respected Kansas pioneer began "stirring up a hornet's nest," reported the Jeffersonian Gazette, it "gave trouble a bigger start than usual."

Learnard was not as famous as John Brown, even in Kansas, but his death the next year elicited reminders that he had been no run-of-the-mill frontier settler: "Another Builder of Kansas Gone," announced the headline in the Topeka Capital story detailing Learnard's demise. As if the message needed emphasis, a caption under the photograph of a distinguished-looking Learnard echoed, "Connected With the Upbuilding of the State."7 It was a task Learnard had cherished doing, although he would have balked at the public hoopla now surrounding his departure. ${ }^{8}$ He disliked exhibiting his accomplishments, and there were many. He studied at respected eastern schools, including Bakersfield Academy and Norwich University in Vermont and Albany Law School in New York. A member of Kansas' first Free-State territorial legislature in 1857, Learnard was also president of the 1859 convention that organized the Republican Party there. In addition, he was a town-founder, circuit court judge, state senator, soldier, newspaper owner, attorney, tax commissioner, husband,

${ }^{6}$ "Truths of History," Jeffersonian Gazette, n.d., Oscar Learnard Papers, UKSRL. The literature on John Brown, radical abolitionist-some would say civil rights terrorist-is quite large. Two books that stand out are Stephen Oates, To Purge This Land With Blood: A Biography of John Brown, $2^{\text {nd }}$ Ed. (Amherst, Massachusetts: University of Massachusetts Press, 1984); and David S. Reynolds, John Brown, Abolitionist: The Man Who Killed Slavery, Sparked the Civil War, and Seeded Civil Rights (New York: Vintage Books, 2006). Recent works contributing to the debate over Brown's memory and legacy include Merrill Peterson, John Brown: The Legend Revisited (Charlottesville, Virginia: University of Virginia Press, 2002); His Soul Goes Marching On: Responses to John Brown and the Harper's Ferry Raid, Paul Finkelman, Ed. (Charlottesville, Virginia: University Press of Virginia, 1995); and Terrible Swift Sword: The Legacy of John Brown, Peggy Russo and Paul Finkelman, Eds. (Athens, Ohio: Ohio University Press, 2005).

7"Another Builder of Kansas Gone," Topeka Capital, n.d., Oscar Learnard Papers, UKSRL.

${ }^{8}$ Notes the Daily Gazette shortly after Learnard's death: "There has never been printed a sketch of the life of Colonel Learnard, because he did not like that sort of thing." See "Death Came: Long Illness of Col. O. E. Learnard Ended by Death Early This Morning," The Daily Gazette, 8 November 1911, Oscar Learnard Papers, UKSRL. 
father, and administrator of a federal Indian school. ${ }^{9}$ It was a satisfying and busy life, one that he truly hated leaving, according to news reports made at his death. ${ }^{10}$

Oscar Learnard was a 24-year-old Vermont migrant with a fresh law degree and military college training only recently arrived in Kansas Territory amidst the chaos of the territorial civil war that inspired the term "Bleeding Kansas." He went looking for land and a future, but events soon swept him into the Free State forces, where before long he commanded a cavalry regiment of volunteers. The familiar camaraderie there and in the "Yankee Town" of Lawrence told him he had found home. Learnard quickly inserted himself into the political and entrepreneurial bustle around him. He felt at ease doing so, since for many years he and close male associates had mapped a blueprint for surviving in competitive environments without damaging others, or themselves, in the process. Codes of masculine conduct formulated in Vermont among an assembly of well-intentioned men-his father and close schoolmates-undergirded this strategy.

\section{Brothers and sisters of the heart}

As an academy student back in New England, Learnard was apparently prone to pessimism concerning his situation in life, which moved one friend to scold: "You are blessed with kind and indulgent parents and a sister to see to your every want. Your every wish is gratified and an education that will take you

\footnotetext{
${ }^{9}$ Biographical information relating to Learnard exists in a variety of obituaries and reminiscences, including Learnard's own, collected in the Oscar Learnard Papers, UKSRL. Learnard's brief autobiographical account appears in "Death Came" The Daily Gazette, 8 November 1911, Oscar Learnard Papers, UKSRL. Also see biographical entries in Coffey County Vol.1 (Coffey County, Kansas: Coffey County Today, 1987), 64; and William E. Connelley, A Standard History of Kansas and Kansans Vol. 5 (Chicago: Lewis Publishing Company, 1918), 2424-2425.

${ }^{10 " C o l . ~ O . ~ E . ~ L e a r n a r d ~ P a s s e d ~ A w a y ~ a t ~ h i s ~ H o m e ~ E a r l y ~ t h i s ~ M o r n i n g, " ~} 6$ November 1911, clipping in Oscar Learnard Papers, UKSRL. The reporter for this unspecified newspaper wrote: "To the end Col. Learnard wished to live as he always had loved life."
} 
comfortably through the world. Kind friends greet you everywhere."11 Learnard knew his friend was right, of course, but he also knew this particular young man, who favored recreational outings more than befitted the serious college-bound scholar, was making excuses for his own relatively lackluster performance. Nonetheless, they were devoted friends, and part of a larger coterie of male schoolmates who were completely aware of each others' relative abilities. ${ }^{12}$ They also were immutably and immovably loyal, which provided safe boundaries within which to experiment with masculine conduct. ${ }^{13}$

Learnard's circle of male associates grew from a core group of close friends at Bakersfield Academy-many of whom, like Learnard, also lived nearby - to include later fellow members of a quasi-fraternity at a Vermont military college. Most took the investment of their "mental wealth" very seriously, and viewed these years of hard study as down payment toward promising futures. They adored belles-lettres and oratorical displays and followed the lyceum circuit. ${ }^{14}$ Many taught school or clerked between prep school and college. Some, like Learnard, traveled through the South or West and some, again like Learnard, did so in an effort to repair health they thought had been damaged by over study. All, however, identified more or less with some circle of young men that constituted Learnard's closest companions.

\footnotetext{
${ }^{11}$ George Wood to Oscar Learnard, 14 September 1851, Oscar Learnard Papers, UKSRL.

${ }^{12} \mathrm{~A}$ good description of young men's evaluations of classmates' relative abilities, and resulting social alignments, appears in Hamilton Holman, "An Indiana College Boy in 1836: The Diary of Richard Henry Holman," Indiana Magazine of History 49 (September 1953): 281-306.

${ }^{13}$ Mary Ann Clawson notes the preponderance in the nineteenth-century United States of "collective" and "extrafamilial" masculine association. "Their effect," she says, "was to promote solidarity among men, to make them aware of their separation from women, and thus to enforce and facilitate the exercise of masculine power." See Mary Ann Clawson, Constructing Brotherhood: Class, Gender, and Fraternalism," (Princeton: Princeton University Press, 1989) 178.

${ }^{14}$ According to Rita Saslaw, improvement in literary skills was, for nineteenth-century college students, considered a path to moral self-improvement, which was the "primary goal of college and of life." See Rita S. Saslaw, "Student Societies in Nineteenth Century Ohio: Misconceptions and Realities, Ohio History 88 (Spring 1979), 198-210.
} 
There were other important people in Learnard's life, of course. He had no biological brothers, but his parents and sister provided a warm and nurturing domestic base, even if the family did not own a home during this time. Perhaps this was the result of the elder Learnard's financial difficulties, for he had endured a business downturn. Consequently, Oscar knew he could not depend on the financial and educational support traditionally expected from New England fathers launching their sons' futures. ${ }^{15}$ As a merchant, however, Tracy Learnard had garnered a good deal of respect in their Vermont region, even dabbling in politics and judicial administration, and was pleased that his talented only son acquitted himself so notably in scholarly pursuits. Aside from Learnard's school chums and a temporary Southern employer, his father represents the only other significant influence during this period. Oscar and his father were close, and the younger man exhibited a protective and tender desire to offset his father's embarrassing and uncomfortable situation, a bond that suggests divergence from the typical emotional alignment of middle-class Victorian sons with their mothers. ${ }^{16}$ Learnard corresponded almost exclusively with his father and male cohort, denoting the existence of a strongly gendered network of evaluation and mutual expectation.

On the other hand, women did not exist outside the realm of Learnard's male circle, and for a time contributed significantly to how it functioned. At Bakersfield Academy, a co-educational institution with slightly under three hundred students, Oscar and his male friends operated socially within two overlapping circles, one entirely male and another expanded one that included female friends. Oscar and sister Amanda both attended the institution located near their home, and many from Oscar's circle there also came from the

\footnotetext{
${ }^{15}$ Anne C. Rose, Victorian America and the Civil War (New York: Cambridge University Press, 1992), 84; and Anne Lombard, Making Manhood: Growing Up Male in Colonial New England (Cambridge: Harvard University Press, 2003), Chapter One.

${ }^{16}$ Ibid., 163.
} 
surrounding region. Learnard's friends used the language of family to express the closeness they felt for each other. One young woman described it this way:

Here we stand-a band of brothers and sisters deeply interested in the welfare of each other-I need not mention the names of those who compose this band-they are treasured in the recess of the heart, on memory's tablet, not soon to be obliterated,--at the response of each name to us endeared, will hover over us the hallowed associations of happy days. ${ }^{17}$

Indeed, Learnard's closest friends of both sexes often addressed each other as "brother" or "sister," whether in direct address or while writing about someone to a third party.

Within a few years, Learnard's interests and activities steered him toward a near-total reliance on his male cohort. However, as he grew into early adulthood, Learnard and his male peers tested their notions about masculine cooperation and competition in a setting that assumed female companions were still a significant part of their interactions. Moreover, the close, familial affection that bound the entire group of young people together allowed young men to test their bonds of loyalty to each other from within a sheltered and nurturing environment. There, the language of family reminded them of the safety of affections and good intentions of friends. This "family," however, existed as a sheltering transitional space for young men only too aware they must soon strike out to test their mettle in the wider world.

${ }^{17}$ Ann Burdick to Oscar Learnard, 30 January 1850, Oscar Learnard Papers, UKSRL. Ann Burdick was the wife of L. F. Burdick, a slightly older friend of Oscar's who had also gone through Bakersfield Academy. Information on the Academy itself appears in Catalogue of the Officers and Students of Bakersfield Academical Institution (Windsor, 1851). This booklet is part of an extensive collection of educational publications at the American Antiquarian Society, Worcester, Massachusetts. Martha Tomhave Blauvelt observes a similar manifestation in the heterosocial friendships of young nineteenth-century academy women that "existed alongside women's loving feelings for each other, almost in a parallel universe." See The Work of the Heart: Young Women and Emotion, 1780-1830 (Charlottesville, Virginia: University of Virginia Press, 2007), 60. 
Despite the fact that Oscar's local male and mixed-gender circles cooperated and overlapped, his masculine cohort still discovered that feminine associates could be the source of a good deal of confusion. Relations to the other sex inspired frequent contemplation and debate, providing insight into the masculine code that governed this assembly of young men. The fellows of Oscar Learnard's circle contemplated young women on two levels. Considered as a class, women of good intentions required chivalrous protection, even as they innocently tempted young men away from preparations for future success. Women whose notoriety placed them outside that category elicited alarm and dismay. As individuals-friends and potential sweethearts-they inspired intense devotion.

The mere presence of women demanded the restraint of masculine passions, which the young men often took it upon themselves to exhort to male friends. After all, wrote one in Learnard's male cohort, "[W]hat should we be [without] their softening, virtuous examples and precepts . . . . [C]oarse-acting villains." This friend coached Learnard how to negotiate social challenges involving women with whom they were also friends: "Be to them all . . . a brother. Turn aside every assassin's hand that is raised to wound their virtue or honor, and even if the blow must fall, apply the balm of consolation rather than the gall of denunciation." ${ }^{18}$

Even the author of such high-minded rhetoric acknowledged that wellintentioned men were still libidinous creatures, capable of sacrificing chivalry to sexual desire: "Had I it in my power tonight to swerve any young lady . . . from the path of virtue and gratify my own selfish propensities. . I would scourge such

\footnotetext{
${ }^{18}$ L. F. Burdick to Oscar Learnard, 29 April 1850, Oscar Learnard Papers, UKSRL. Rodney Hessinger notes that by the mid-nineteenth century, "bourgeois males were being urged to respect women by adopting a standard of chastity." See Seduced, Abandoned, and Reborn: Visions of Youth in Middle-Class America, 1780-1850 (Philadelphia: University of Pennsylvania Press, 2005), 68.
} 
an idea from my mind as a traitor, a treasoner, a murderer." ${ }^{19}$ His "selfish propensities" notwithstanding, this gentleman nobly proclaimed that on the "great day of account" any charges that he had "even insulted the feelings of any lady" would prove the result of misunderstanding. He implored Learnard never to "stoop to passion, but to always live the high-minded, whole-souled, never flinching protector and guarder of female virtue." ${ }^{12}$ The message from this slightly older male companion was that the noble man curbed his sexual energy in the service of honor-that of young women of course, but also his own. Learnard's friends did not view it as a violation of a male friends' privacy to chide him to manage his "passions" so as not to shame himself or his companions.

Once Learnard grew a little older and broadened his acquaintances, an occasional friend challenged the superiority of feminine rectitude. One cocky cohort from military college boasted that he was "decidedly in the field," and encouraged his chum to "get acquainted" with the "fine" women nearby in particularly unchivalrous terms: "Put it to them if possible," he advised. "They all need and deserve it probably. ${ }^{21}$ Such bravado fell outside the norm for Oscar's associates, however, who generally urged each other to watch over the virtue of female acquaintances. One warned Oscar of the potentially destructive effects of the world on women not shielded by a coterie of protective male friends. From boomtown San Francisco, he reported that most women there "go in for their share" of the "satiating and unholy delights of the body." These "abandoned"

\footnotetext{
${ }^{19}$ Ibid. According to Anne Rose, "[T]houghts of physical passion evoked from [middle-class Victorian] men extreme reactions of enthusiasm, revulsion, and silence." Rose, 155.

${ }^{20}$ Ibid. The Illustrated Manners Book of 1855 instructed its male audience: "The man who is liable to fits of passion; who cannot control his temper, but is subject to ungovernable excitements of any kind, is always in danger." Quoted in John F. Kasson, Rudeness and Civility: Manners in Nineteenth-Century Urban America (New York: Hill and Wang, 1990), 148. Kasson notes the particular vulnerability of young ladies' reputations and the "elaborate form of protection" they required of men. See 132.

${ }^{21}$ W. D. Munson to Oscar Learnard, 25 November 1853, Oscar Learnard Papers, UKSRL. While it does not deal directly with the issue of boasting, whether specious or not, Thomas Foster observes that New England men traditionally shared in gossip and "town talk" about other men's sexual exploits. See Sex and the Eighteenth-Century Man: Massachusetts and the History of Sexuality in America (Boston: Beacon Press, 2006), Chapter Four.
} 
women, he added, "stand with men at the bar," "deal the cards" in the "gambling house," and "use the name of God in vain."22

For the most part, however, partaking of "women's society" in Oscar's world portended jolly sleigh rides, respite from serious endeavors, and occasional stolen moments of affection. Friends from Learnard's home region were a "band of brothers and sisters" who typically planned outings in mixed groups.$^{23}$ Some of Learnard's male friends tentatively shared among themselves information about rare intimate meetings with young women, which afforded the pleasure of "gaz[ing] with admiration on [nature's] handiwork." In "secluded" surroundings, wrote one, "lovely and virtuous females with rosy lips and beaming eyes will tend to beguile the tedious hours of the long winter evenings." Although this fellow claimed to enjoy hard study, "still," he wrote, "I would like to make a little sugar-just enough to sweeten my lips." ${ }^{24}$ In small exchanges such as these, Oscar's young male companions tested the bounds of appropriate male contact with women, relying on each other to help guide and regulate their behavior.

At the academy, Learnard was the third member of a self-styled "bachelor's trio." The remaining two confessed a particular "fondness for women." Whether Learnard shared this predilection is not clear, but the ladies evidently favored the confident and well-spoken Oscar, a standout scholar and orator. Male friends bemoaned their own difficulty in making feminine connections, while Learnard appeared to attract them effortlessly without neglecting his more serious pursuits. Yet, Learnard's companions generally

\footnotetext{
${ }^{22}$ Charles Cleveland to Oscar Learnard, 26 July 1853, Oscar Learnard Papers, UKSRL. If Learnard's father or uncles offered any advice regarding his interactions with young ladies, it did not appear in the extant correspondence for this period. Learnard apparently omitted the topic of romantic interests from his correspondence to them, as well.

${ }^{23}$ Ann Burdick to Oscar Learnard, 30 January 1850, Oscar Learnard Papers, UKSRL.

${ }^{24}$ John Maynard to Oscar Learnard, 2 April 1852, 21 September 1853, and 21 March 1853, Oscar Learnard Papers, UKSRL.
} 
acknowledged his eminence, rather than resented it. One remarked that when Learnard left the area his own "diffidence" with their "crowd of girls" subsided: "I can lick the world now you are gone!" ${ }^{125}$ Learnard's sway with young women, whether premeditated or not, was salient enough to prompt one slightly older and now-married friend to pen an overblown diatribe of warning on restraining masculine passions to protect femininity's claim of place on the pedestal of virtue.

Single women presented a decided threat to the determined young man on the move, however. Learnard's friends knew that love, though delightful, was distracting and also interfered with important pursuits. Wrote one: "I begin to realize that Eunice's refusal to my proposal was in accordance with my best interest, as my mind has now all its power to give to my affairs." ${ }^{26}$ As Learnard faced adulthood and eventual independence, increasingly he concentrated his attention upon forging a successful future, excepting one uncharacteristic temporary slip into pining for the company of two favored feminine companions, between whom he was torn. One male friend, taking advantage of Oscar's temporary confusion, teasingly reminded Learnard that when it came time to choose a compatible wife, he should perhaps temper his ambition. ${ }^{27}$

Extant sources are nearly mum regarding precisely how Learnard formulated his plan for navigating past potential romantic obstacles in the path of his scholastic and professional goals. One clue exists in a male friend's reply to something Learnard must have written to him earlier. The friend wrote, "I am surprised at your conclusion in regard to women-but do not know as I have any opinion in regard to them. Still, sometimes I love to have a time with the lovely

\footnotetext{
${ }^{25}$ John Maynard to Oscar Learnard, 18 September 1852, 20 October 1852, and 2 April 1852, Oscar Learnard Papers, UKSRL.

${ }^{26}$ Charles Cleveland to Oscar Learnard, July 26, 1853, Oscar Learnard Papers, UKSRL.

${ }^{27}$ L. F. Burdick to Oscar Learnard, 18 June (n.d.). Nineteenth-century middle-class manners promoted the judicious avoidance of young women's first names. See Kasson, 145.
} 
creatures." $^{28}$ This cryptic reference implies that Learnard may have at some point purposefully determined that he would avoid romantic entanglements. Somehow, Learnard acquitted demanding social obligations to friends and their families, deflected frequent attempts of feminine acquaintances to gain his favor, shone in his scholarly pursuits, and still garnered the loving respect of his "brothers" and "sisters." Not only the smitten young lady who mailed him a beautiful leaf as love's token, but also the dejected suitor whose proposal of marriage was rejected, he assumed, because his intended favored Learnard, recognized that in matters of love Learnard was positioned to be choosy. Remarkably, the bounds of this coterie's friendship extended far enough to cover broken hearts and crushed egos without damaging their relations to each other. Such conditions promoted confidence in ambitious young men like Learnard even as they probably also tempered unfettered drive and inordinate independency.

The young men and women of Learnard's broadest circle did not allow romantic entanglements to damage their normally affectionate and loyal relations. In one instance, a love triangle posed a challenge to the close-knit group, but evidence suggests that the male friends cooperated outside the larger group to resolve it among themselves without weakening the bonds of masculine fealty. Such instances of potential competition between male friends mark one area where Learnard and his male chums envisioned their bond in distinction to the one they also shared with female associates. Their masculine bond took primacy at this time and required protection from threats to its security coming from outside the acknowledged circle of male friends.

The assumption in this merry group of young men and women was that all members loved and supported the others. Within Oscar's male circle, however,

\footnotetext{
${ }^{28}$ John Maynard to Oscar Learnard, 21 September 1853, Oscar Learnard Papers, UKSRL.
} 
that affectionate loyalty took on an especially close dimension. One of Learnard's male friends indicated there were some things he would only discuss with Learnard, and face-to-face. Another found himself rejected by a young woman who apparently favored Learnard, but, nonetheless, bared his soul to Learnard in correspondence. Granted, Learnard was the better man and the girl he loved deserved the best. After all, he asserted, "it must be a kindred heart or none." On the other hand, he confessed, "I cannot forget to think of her, as the attachment I formed has proved too strong. This is for you alone, and if you love me you will not betray it"29 The spurned young man completely trusted the ties of masculine fealty that bound these companions together and elevated that filial devotion over potential romantic attachments. Even though the young adults among Oscar's group of friends included both genders, their interactions functioned to promote increased male bonding.

Despite this fact, Learnard's male companions did not pull away from mixed-gender contact, and constantly exhorted each other to visit their mutual female friends, as well as each other's sisters and mothers. Between friends of both genders, expressions of affection appear remarkably spontaneous and sincere. Women and men both instructed letter writers to send their kisses to the recipients. One male friend instructed Learnard to "kiss all the girls for me." A married friend chided him teasingly for affectionate exchanges made between Learnard and his wife, "for kisses enough has been done in that line by you both." When a young woman from their coterie succumbed to typhus, the same fellow gushed, "I never knew until I knew that she was gone, how much I loved, how dearly I cherished her. It seemed as though a part of myself was torn from me. ${ }^{30}$

\footnotetext{
${ }^{29}$ Charles Cleveland to Oscar Learnard, 25 March 1854 and undated letter,Oscar Learnard Papers, UKSRL.

${ }^{30}$ The freedom with which Learnard's intimate circle-male and female-expressed affection runs exactly contrary to what C. Dallett Hemphill notes the authors of the myriad nineteenth-century advice manuals suggested was appropriate for respectable young men and women. See Bowing to Necessities: A History of Manners in America, 1620-1860 (New York: Oxford University Press, 1999), Chapter Nine. The suggestion
} 
By contrast, Learnard's written interactions with his mother and sister during his absences from home appear restrained and certainly less lighthearted. The exigencies of their life in recent years commanded pragmatism and a focus on strategies for pulling through financially. Moreover, what need had a young man known for special eloquence to display such to family members, who knew him long before he was a celebrated local scholar? Although Learnard was clearly affectionate and devoted to his mother, his relationship with her, nonetheless, evinced a good deal of tension. ${ }^{31}$ On one occasion, away from home, he wrote: "You request me to write often but do not seem inclined to make a ready return. Your receipts from me will be in proportion to mine from you. Please remember that I am as anxious to hear from home are you are from me." Writing on another occasion from Ohio, Learnard reminded her that he accepted his clerking position there and even extended his stay "to gratify you more than any other reason." Younger sister Amanda impatiently watched for letters from Oscar, which his family generally shared with friends eager to stay abreast of his activities. But Learnard's messages to her were generally straightforward and almost paternal. He encouraged his sister to ease the family's financial burden. "Amanda," he commanded, "you must begin to do something for yourself. Teach. Learn a trade or something else, so that you may be independent. We are both

to "kiss all the girls" appears in John Maynard to Oscar Learnard 27 February 1853 . In L. F. Burdick to OEL, 16 September (n.d.). Note that Burdick's passionate description of his feelings for a single female friend seems remarkably out of place by today's standards of social etiquette. It was not so in the written discourse of middle-class Victorian America, where florid, sentimental writing was often highly prized. See Karen Halttunen, Confidence Men and Painted Women: A Study of Middle-Class Culture in America, 1830-1870 (New Haven: Yale University Press, 1982). Burdick's wife, Ann, was similarly inconsolable, for Burdick notes that she "wept herself almost sick." Learnard, even in grief, could not escape attention as the object of so many young ladies' interests. He was mentioned at the funeral, according to Burdick, and the deceased girl's mother asked that Burdick write him the sad news, noting that "she did not suppose there was anything like an engagement between you, but yet she knew that Mary felt an attachment for you that she entertained for but very few."

${ }^{31}$ Antebellum middle-class mothers tended to be closer to their sons than were fathers, but the reverse appears to have been true in the Learnard household. Perhaps the family's financial downturn disrupted what might otherwise have been the normal state of affairs. Anne Rose does note the persistent dominance of fathers on the overall emotional life of the middle-class household, despite the prevalence of domestic literature aimed at women. See Rose, 163, 168-169. 
of us better able to support ourselves than Father and Mother. ${ }^{132}$ On the whole, Learnard's correspondence with his mother and sister reflected the reality of financial downturn for this middle-class New England family. This young man's fantasies and dreams held limited sway there, but were celebrated freely within his coterie of devoted friends, especially his circle of young male companions.

\section{In pursuit of "healthy action"}

Feminine attractions may have challenged the cohesiveness of Learnard's male cohort, but unreliable health was a more demanding mistress. Health problems continually threatened the disruption of educational pursuits-especially college, which could be a significant component in the development of the "whole man" and quest for respected futures. Although there was no direct connection between college and desirable careers in the nineteenth century such as exists today, college graduates were an elite group within the male workforce before the Civil War, constituting not over one per cent. Most male graduates eventually pursued careers in education, government, medicine, law, and the clergy, the very arenas from which many of society's leaders came. Similar to Learnard, large numbers of those students came from "middling circumstances" and many harnessed "intellectual curiosity" to a desire to rise. The financial downturn of Learnard's father created an implied demand that Learnard, as the only son, stay physically resilient enough to build a secure future for himself, and possibly his family. However, even Learnard's friends whose circumstances were more privileged labored under the near universal nineteenth-century expectation that young men must demonstrate their worth by their own accomplishments. The most frequent source of disruption to the plans of striving young men in the early

${ }^{32}$ Oscar Learnard to Polly Learnard, 24 May 1852, Oscar Learnard Papers, UKSRL. Blauvelt suggests that "[Litchfield] Academy girls expressed themselves one way with teachers and another with friends," suggesting that distinct modes of sociality may have marked the various groups with which young people interacted. See page 146. 
republic was unreliable health. Consequently, it was also an ongoing concern of all their acquaintances and constant topic of conversation. ${ }^{33}$

For one thing, ambitious young men had to balance diligence in educational pursuits against the physical dangers thought to attend excessive study. With striking uniformity, Learnard's companions asserted the common belief that mental exertion could dangerously weaken or even destroy masculine vigor. They worried over the ability of each one to resolve the tension between study and health in order to fulfill his life's goals. ${ }^{34}$ One male friend, confirming his devotion to Learnard, noted, "I would glory to have you expand your mental strength, though I cherish not the slightest desire to have you ruin your health by the means." The life of the serious student was, they all agreed, a demanding one. Too much mental exercise strengthened the mind at the expense of the body's other functions, which also required attention. "For what can the mental ability perform and pleasure the mind receive if the other stirring powers are not constantly sustained within their own proper bounds," queried one cohort. ${ }^{35}$ The education most of them acknowledged as a potential guarantor of a distinguished life presented a special dilemma to those who, like Learnard, seemed most turned toward the scholar's life. The most diligent students were at higher risk for ruined health, but without serious application to study, a young man did not achieve that visible success that marked him before the world for future success.

${ }^{33}$ The American College in the Nineteenth Century, Roger L. Geiger, Ed. (Nashville: Vanderbilt University Press, 2000), 3-4.

${ }^{34}$ The perceived dangers of mental exertion did not apply only to men in nineteenth-century America. Excessive reading or thinking contributed to physical decline in women, as well, according to contemporary medical thinking. See Edward Pessen, Jacksonian America: Society, Personality, and Politics (Urbana: University of Illinois, 1985), 65. Belief in a possible connection between deficient character and infirmity lingered into the early decades of the century, as well as the particular association of nervous conditions with femininity, leaving young men stressed by scholarly overwork especially vulnerable to the social associations that might accompany illness contacted under those circumstances. See Pessen, 47; Phillip Andrew Gibbs, "Seasons of American Manhood, 1750-1860: Mirror of the Changing Republic" (Ph.D. diss., Mississippi State University, 1988), 114-116 and 205-212; and Roberta J. Park, "Biological Thought, Athletics and the Formation of a 'Man of Character': 1830-1900," in Manliness and Morality, eds. Mangan and Walvin, 7-13.

${ }^{35}$ Charles Cleveland to Oscar Learnard, 28 June 1853 and 22 June 1853. 
Learnard struggled to find that balance in his own health. Intermittent headaches plagued him. He was selected to deliver the commencement oration at Bakersfield academy, but could not, suffering some illness that also forced a temporary end to his scholastic pursuits and sent him South for a time seeking a return of physical vigor. Learnard also later endured at least one "bilious attack" that wrestled him low for several days. ${ }^{36}$

III health threatened more than the interruption of mental exertion, however, for sound health was intrinsically linked to masculine character. One companion advised Learnard to exercise routinely, but not too violently nor for too long, linking "regularity [of] habits" with "virtue's cause. ${ }^{137}$ Some years later, Learnard assured his father that he understood this component of personal development. "Father," he wrote, "I do not believe you will censure me when I tell you that, regardless of money matters, if life and health are spared me, I will be a man. ${ }^{138} \mathrm{~A}$ sound body did not necessarily make the man, but Learnard linked his conception of manhood to sustainable vitality, and to the making of a potentially successful self. Learnard's companions connected the very concept of health with the same dynamic push that characterized their other ambitious pursuits. A sound constitution displayed "healthy action" and the "stirring powers" of its systems guaranteed the "wonted strength" some feared they might never experience again. One friend reminded Learnard that soundness of body and of character were not only linked, but required purposeful exertion: "[K]eep in. . . active exercise those principles and sources of action that elevate the whole man. ${ }^{139}$

\footnotetext{
${ }^{36}$ Oscar Learnard to "Dear Friends," 25 July 1855, Oscar Learnard Papers, UKSRL.

${ }^{37}$ L. F. Burdick to Oscar Learnard, 29 April 1850, Oscar Learnard Papers, UKSRL.

${ }^{38}$ Oscar Learnard to Tracy Learnard, 2 August 1852, Oscar Learnard Papers, UKSRL.

${ }^{39}$ L. F. Burdick to Oscar Learnard, 29 April 1850, Oscar Learnard Papers, UKSRL.
} 
The experiences of Learnard's circle taught them that despite their own best efforts, health was too often unpredictable and ephemeral. When typhus struck seven members of a close female friend's household, she and most likely a very young brother both died. Too often, access to professional medical care effected no change in outcome and inspired little confidence. Learnard's Tennessee employer, originally annoyed that he must pay "legitimates" to attend his sick wife, later gave this sad report:

"My dear wife died last Thursday. ... She had been complaining for a few days and said herself that her disease was mortal--but the doctors laughed about it and said that painful, it was curable, and that she was in no danger. . . . She suffered intense agony. . . . [and] died in my arms. ${ }^{40 "}$

Most challenges to health were not accompanied with such dramatic scenes. One chronically frail chum from Learnard's masculine coterie struggled over a long period to remedy his "weakened constitution," partly by visiting "water cure" resorts. ${ }^{41}$ Dramatic or mundane, evidence existed everywhere that illness could occur almost without warning and disrupt a young man's pursuit of goals. Ambitious young men in the early republic, Learnard's male friends included, felt intensely vulnerable. They understood precisely how precarious was achieving the independency of manhood when it required physical resilience, which itself was maddeningly difficult to maintain.

Extended travel, especially to the South and West, offered hope to some of achieving renewed vigor. There, moderate climates and healthful air might hasten a return to vitality. Learnard himself left Vermont and canceled plans to attend college-perhaps, he thought, permanently_in an effort to regain physical robustness. Clerking or traveling sales positions, neither of which he fancied, unfortunately, were easily obtainable in developing regions, and neither

\footnotetext{
${ }^{40}$ Alex MacKenzie to Oscar Learnard, 30 August 1852 and 21 September 1853, Oscar Learnard Papers, UKSRL.

${ }^{41}$ Charles Cleveland to Oscar Learnard, 8 December 1854, Oscar Learnard Papers, UKSRL.
} 
dangerously affected bodily resources as did mental exertion. Learnard's ambitious friends periodically suspended their studies and left Vermont, hoping some enchantment in Ohio, Tennessee, or California would eventually free them from poor health and unsatisfactory temporary vocations, allowing their return to school.

Nonprofessional jobs proffered their own charms to health, however. Common labor, because it depended more upon brawn than mental agility, offset the drain of intense study on a young man's overall strength. Temporarily waylaid from school by infirmity, one former classmate commented, "As farmer, I engage daily in physical labor and reap probably some good results." ${ }^{42}$ Another, similarly stalled in scholarly activities due to illness, associated strength and sun-kissed color with nonprofessional occupations. He cheerfully boasted, "Instead of carrying round a pale, sunken countenance, you can now see a black, saucy, and insignificant looking youth, and a member of the counter-jumpers, store sweep, or mercantile tribe!"43 Notice, however, his assertion that the insignificant youth gave this appearance, and the implication that grown men of significance and serious pursuits were probably more pale and decidedly less spry. And here was the dilemma: The very futures they sought health to achieve might return them to the same weakened state. This young man credited his physical turnaround mostly to primitive and manly activities out of doors. "For three weeks," he wrote, "spent my time hunting and fishing. My health immediately commenced improving and continues so to do. Think nothing of eating six potatoes and other things in proportion." ${ }^{44}$ Today, young men worn down by intense scholarly pursuits speak of vacations and time spent in less stressful circumstances. For these ambitious Yankees, threatened with physical obstacles to charting a successful course, primal activities and manual labor returned them

\footnotetext{
${ }^{42}$ Charles Cleveland to Oscar Learnard, 19 June 1852, Oscar Learnard Papers, UKSRL.

${ }^{43}$ L. P. Wetherly to Oscar Learnard, 9 May 1853, Oscar Learnard Papers, UKSRL.

${ }^{44}$ L. P. Weatherly to Oscar Learnard, 9 May 1853, Oscar Learnard Papers, UKSRL.
} 
to a more natural state and brought them back in touch with the essential masculine component of muscular strength.

The young men in Learnard's coterie felt the need to jokingly boast of the means by which they reclaimed physical health because they all knew that avenue existed due to their having temporarily failed at what they really hoped to achieve. Becoming clerks or farmers was not on life's agenda for any of Learnard's male friends, at least not at this stage in life. ${ }^{45}$ Self-effacing jests acknowledged their sense of vulnerability even as it affirmed that these young men trusted each other's good intentions toward each other. This they confirmed in other ways, as well. They watched over each other, worrying about problems with health or education, offering advice or sometimes even financial aid that might have come from older male relatives in the past. Oscar's masculine cohort reinforced in each other a code of success by which they encouraged, aided, or silently judged each other. They all agreed, however, that action was the key to all success-action in life, action in education, and finding that "healthy action" of physical systems that for some appeared the most elusive component to achieving life's goals.

\section{"Pecuniary matters"}

Fascination with health-producing enchantments outside New England did not erase these young men's allegiance to their region of birth. Wherever they traveled, they compared new surroundings and the character of inhabitants there with those they left behind. Regarding Huntsville, Alabama, Learnard wrote that it

\footnotetext{
${ }^{45}$ Although assumed to be the logical path to successful business careers, clerking was not seriously pursued as such by any of Learnard's correspondents, and certainly not by Learnard, who made plain his intention to avoid a mercantile future, perhaps related to his father's experiences. See Brian P. Luskey, On the Make: Clerks and the Quest for Capital in Nineteenth-Century America (New York: New York University Press, 2010), Chapter One.
} 
was "the most charming place I ever saw, out of New England." ${ }^{46}$ The place he landed in Ohio was, however, "very unlike old Vermont." ${ }^{\text {"47 }}$

Learnard's masculine circle compared other people and locales with home for reasons other than outward charm. Yankees possessed certain agreed-upon qualities, according to these correspondents, that were especially appealing to young men chasing success. Yankees were wise in politics, shrewd in business, and unpretentious in religion. Undeterred by hard work, they stood poised to contribute necessary energy - for which they were "reputed . . . the world over"to to undeveloped frontier regions. They valued education, and, like "hero [Ethan] Allen," were smart enough to play an occasional "Yankee trick." ${ }^{48}$ One former classmate, contemplating a move to a distant college, mused to Learnard regarding that region's desirability as a temporary home: "There is everything here to make one pleasant. The country is delightful and the villages beautiful. The people are Yankees; I suppose that is recommendation enough. ${ }^{149}$

The presence of Yankee acquaintances is what generally attracted Learnard's west-venturing friends to particular areas outside their Eastern homes. They quickly sought Vermonters or other New Englanders in each place and then set about leveraging connections to benefit themselves socially and

\footnotetext{
${ }^{46}$ Oscar Learnard to Tracy Learnard, 23 August 1852, Oscar Learnard Papers, UKSRL.

${ }^{47}$ Oscar Learnard to Tracy, Polly, and Amanda Learnard, 24 March 1852, Oscar Learnard Papers, UKSRL.

${ }^{48}$ William Gibbs to Oscar Learnard, 24 July 1850, Oscar Learnard Papers, UKSRL. Whether Learnard's companions formulated their views of Yankeeness through observation or via the general pervasiveness of regional stereotypes in nineteenth-century America is not certain. Their conclusions regarding Yankees generally contain the more positive of the variety of traits thought to characterize New Englanders. See William R. Taylor, Cavalier and Yankee: The Old South and American National Character (Garden City, New York: Anchor Books, 1963), and Susan E. Gray, The Yankee West: Community Life on the Michigan

Frontier (Chapel Hill: University of North Carolina Press, 1996). Migrants of the "Universal Yankee Nation" to the upper midwest elicited praise for their "steadiness and moral probity, but condemn[ation] for their pennypinching and mean spiritedness. Gray, 4. The assumed connection between Yankees and trickiness is discussed in Halttunen, 30-32.

${ }^{49}$ F. Rogan to Oscar Learnard, 19 August 1851, Oscar Learnard Papers, UKSRL.
} 
professionally. ${ }^{50}$ They provided each other the names of agreeable out-of-town relatives, acquaintances, employers, and hotels, hoping to cushion a green young Yankee's landing on unfamiliar soil. For ambitious, educated young men bound by intense filial loyalty, any other course would have seemed unnatural. Learnard's cohort constructed a web of contacts across New England and throughout the West and South to arrange trade, secure jobs, and ease the transition of relocation. One companion, anticipating a move to California, predicted that other transplanted New Englanders would embrace him upon his arrival: "I am to leave . . . the dear relations that cluster around me here . . . yet I do not go into an unknown country. Where I go I expect to find friends, and friends who will assist and direct me. ${ }^{51}$ As expected, this fellow quickly aligned himself in San Francisco with other New Englanders, found Vermonters he had known previously, and even located a Congregational church, the religious equivalent of an old New England friend.

Favorable connections only went so far, though, in Learnard's case, and the inevitable financial problems he encountered while away he generally solved as he went along. His father helped him with a fifty dollar advance when Learnard left for his traveling sales job in the South, but Learnard expected to repay that from his earnings there. There is no evidence that his Ohio uncle was positioned to provide significant assistance, either. Traditionally, New England fathers had felt it their duty to provide sons either with land for farming, a previously arranged craft apprenticeship, or money for a college education. In other words, the duty fell upon them to launch sons into the world adequately prepared to earn their way in it. By the nineteenth century, those traditions came under challenge in New England, land having become more difficult to provide

\footnotetext{
${ }^{50}$ For an assessment the community-building process of westering Yankees, see Gray, The Yankee West; Virginia and Robert McCormick, New Englanders on the Ohio Frontier: Migration and Settlement of Worthington, Ohio (Kent, Ohio: Kent University Press, 1998); and Kim M. Gruenwald, River of Enterprise: The Commercial Origins of Regional Identity in the Ohio Valley, 1790-1850 (Bloomington, Indiana: Indiana University Press, 2002).

${ }^{51}$ Charles Cleveland to Oscar Learnard, 10 January 1853, Oscar Learnard Papers, UKSRL.
} 
and market changes making traditional craft occupations a less obvious route to success. If fathers were unable to launch their sons adequately, family members usually assumed other male relatives, especially brothers, should take up the slack. $^{52}$

However, Oscar had no brothers, his merchant father was in a season of financial transition, and no uncles apparently existed with either the willingness or substantial means to help. Moreover, during his travels Learnard actually helped his father further his Vermont mercantile activities. He located and purchased merchandise-buffalo robes, for example-or assisted in collecting debts. Learnard's primary consideration, one that he shared repeatedly with his parents, was to secure them a future free from financial concern. The only reliable social safety net available to aging parents was to raise sons devoted to their wellbeing whom they also then launched into secure lives of their own. In spite of his family's inability to provide the latter, Oscar remained intent upon including his parents in whatever life he made for himself.

On the other hand, at no time during this period did Oscar Learnard openly admit a serious desire to become wealthy. "I hope you will not allot too much upon my getting rich," he cautioned his father. He must have wondered if the elder Learnard harbored such dreams, for Oscar felt compelled to add, "In every other respect it shall be my endeavor to conform to your wishes. ${ }^{153}$ No doubt, Learnard also wanted to dampen others' predictions of his high success, lest he fall short and disappoint everyone's expectations. Learnard's father had

${ }^{52}$ On the concern New England families traditionally showed regarding the launch of sons' careers, see Lisa Wilson, See Ye Heart of a Man: The Domestic Life of Men in Colonial New England (New Haven: Yale University Press, 1999), 24-36. Learnard did spend a brief time with the uncle's family in Ohio, working as a clerk nearby, but neither the location nor the job offered the kind of prospects he envisioned.

${ }^{53}$ Oscar Learnard to Tracy Learnard, 26 April 1852, Oscar Learnard Papers, UKSRL. Lisa Wilson observes that the traditional goal for ambitious men in New England was what they called "competency" and which she defines as "comfortable if not wealthy." Colonists had viewed "overt quest for wealth" as "suspect." See pages 21-26. 
done all he could to foster his son's educational pursuits, and Oscar knew his father wished he could have done even more. Such devotion demanded acknowledgment and, if possible, recompense: "One thing I promise as a duty I owe, to so attend to pecuniary matters that you may never again be obliged to live any other life than that of ease," he vowed. ${ }^{54}$

In the meantime, Western prospects gleamed. Learnard reported on business conditions wherever he went: cheap land beckoned speculators, specie opened doors for investment ("money counts here"), and merchants were "getting rich." 55 With five-hundred dollars down and most of Oscar's yearly earnings, his father could buy a home in Tennessee, Learnard advised. Despite life's "misfortune," he told the elder man, his "remaining days [could] be spent in ease and happiness, if you will that it be so." His father had no small children to support, Learnard explained, "but you have one that will endeavor to make return in some measure for the ten thousand favors received at your hands." The site of his parents' relocation did not matter to Learnard. If his father preferred Ohio, or even elsewhere in Vermont, he still wanted to help finance the endeavor. ${ }^{56}$ For the time being, Learnard consoled the elder man: "[K]eep up the spirits. And we will stem the current yet." ${ }^{57}$

Despite his close attachment to his father, Learnard counted mostly on connections provided by friends. The young men of his circle emphasized their happiness upon learning of each other's good fortunes. "I am rejoiced to hear of your prosperity," was a typical sentiment. ${ }^{58}$ One companion ventured well beyond this coterie's usual expectations of friendly assistance, however. Claiming

\footnotetext{
${ }^{54}$ Ibid.

${ }^{55}$ Ibid.

${ }^{56}$ Oscar Learnard to Tracy Learnard, 21 June 1852, Oscar Learnard Papers, UKSRL.

${ }^{57}$ Oscar Learnard to Polly Learnard, 24 May 1852, Oscar Learnard Papers, UKSRL.

${ }^{58}$ John Maynard to Oscar Learnard, 5 November 1853, Oscar Learnard Papers, UKSRL.
} 
Learnard as his "intimate friend and brother," Charles Cleveland vowed to help defray Learnard's college expenses from, he announced, a "pure desire to see you prosper." This companion thrilled to the prospect of Learnard's return to classical collegiate studies, and beseeched Learnard not to shorten them to pursue professional legal training. "It is your duty," he wrote. "The world demands it of you, and your success will depend upon it. What I have promised to do toward advancing your good cause, I am going to do, and with my whole heart." ${ }^{.59}$ Ironically, this companion was positioned to help Learnard due to his own adversity, for chronic infirmity had forced his withdrawal from school and relocation to San Francisco, where he found money-if not health's returneasily obtainable. As long as he prospered thusly, Learnard would benefit, no strings attached. "If misfortunes cast her obstructions in my way," he noted, "then I shall only seek consolation in the smiles of your sympathies." This remarkable friend insisted on complete secrecy, for he had, he wrote, "very important reasons that it should be regarded by both of us inviolable." ${ }^{60}$ Cleveland's insistence on complete privacy in the matter remains unexplained. However, Cleveland knew his father observed his spending habits, sometimes with a wary eye, and also probably wished to protect Oscar's pride, and perhaps that of Oscar's family.

Neither Learnard nor the chum who relocated to California was particularly concerned with accumulating wealth at this juncture of their lives. The latter, though busily scouting profitable investments, was not intent simply on stockpiling money. In fact, evidence suggests that he devised a five-year plan for his California venture to fund his own return to college-assuming, of course, the reappearance of good health. For the time being, however, Learnard became the early beneficiary of this pot as Cleveland moved to insure that his former classmate's outstanding talents received proper due. Helping Learnard achieve

\footnotetext{
${ }^{59}$ Charles Cleveland to Oscar Learnard, 25 March 1854, Oscar Learnard Papers, UKSRL.

${ }^{60}$ Charles Cleveland to Oscar Learnard, 13 September 1853, Oscar Learnard Papers, UKSRL.
} 
the college education that Cleveland craved evinced not jealousy, but immense satisfaction. "What I have done," he wrote Learnard, "I have done willingly and without regret. I am now the none poorer." In other words, paying toward his friend's college expenses was not a burden as long as he was no worse off than when he arrived. Apart from the loyalty and camaraderie they convey, these are hardly the words of a man bent on piling up riches, at least not at this stage. ${ }^{61}$

When Learnard moved on from collegiate study and completed law school, even as he stood poised at the threshold of a potentially profitable professional career, acquiring wealth for wealth's sake was not his immediate concern. He illustrated as much to his father when describing his life as a smalltown Ohio lawyer:

My professional business just about pays my board, which fully satisfies me. Sometimes I earn nothing for two full weeks, then a lucky day dawns and I get a five or a ten. Week before last, one day I made ten dollars in less than an hour, and then I was doomed to "dull pursuits," I presume till harvest. Last night I was up until this morning to catch a recreant border for my landlord ... to pay this week's board. This morning I had five dollars, but a brother attorney came along "ded broke" as they say in this country, so I made a transfer of it from my pocket to his. It will come back someday, however, with interest. In the meantime, I have thirty-three cents in my pocket--good American coin." ${ }^{162}$

Learnard had alighted in the quiet Ohio town of Crestline upon the invitation of an old classmate who also practiced law in that vicinity. The fact that Learnard did not linger there long suggests an unwillingness to live very long under such constraints. He certainly exhibited no great concern over ever

${ }^{61} \mathrm{Ibid}$. Charles Cleveland's family was probably better situated financially than Learnard's, and he may have known about the Learnard family's monetary difficulties. At one point, Cleveland considered asking his father to pay for Learnard to join him on his California voyage, but decided against it. It is clear Learnard wanted to go, but lack of funds prevented his making the trip. It may well have been Cleveland's father that $\mathrm{C}$. W. was determined to keep from finding out about the financial assistance given to Learnard. In any case, the younger Cleveland made and tracked his own investments in San Francisco, and money sent to Learnard came specifically from profits made thereby.

${ }^{62}$ Oscar Learnard to "Dear Friends," 9 July 1853, Oscar Learnard Papers, UKSRL. 
collecting the money he so breezily lent a fellow Ohio attorney. ${ }^{63}$ Moreover, at this juncture Learnard was contented to "just about" pay his board through practicing law, and seemed more worried over being "doomed to 'dull pursuits"' than the fact that his pockets were nearly empty. Granted, Learnard felt a kinship with his old classmate and other lawyers in the region, apparently, but this situation lacked the capacity to bind Learnard with these male associates in a clearly delineated and demanding shared goal. Besides, time was steadily passing by and Learnard knew it was up to him to find a situation that would help him to really make something of himself.

The specter of the self-made man hovered before every male American from the middle ranks in nineteenth-century America. ${ }^{64}$ For those like Learnard, raised and educated in concert with middle-class values, the lack of resources necessary to maintain and improve those circumstances threatened the taint of failure and-even worse-the disappointment of expectant family and friends. ${ }^{65}$ Learnard's father expressed a hope that Oscar would overcome such obstacles.

${ }^{63}$ The knowledge that work brought "restraints as well as opportunities" sometimes challenged middle-class Victorians' willingness to accept work that was not sufficiently meaningful. See Rose, 87.

${ }^{64}$ On the pervasiveness of the self-made man myth during this period, see John G. Cawelti, Apostles of the Self-Made Man (Chicago: University of Chicago Press, 1965), 1-3; Michael Kimmel, Manhood in America: A Cultural History (New York: Free Press, 1996), Part One; and Edward Pessen, Riches, Class, and Power: America Before the Civil War (New Brunswick, New Jersey: Transaction Publishers, 1990), 77-79. On its special relationship to the marketplace, see Thomas Augst, The Clerk's Tale: Young Men and Moral Life in Nineteenth-Century America (Chicago: University of Chicago Press, 2003), 5-7, and Brian Luskey, On the Make. Halttunen notes the connection between social liminality and the concept of the self-made man; see pages 27-32. Also see Daniel Walker Howe's work on self-fashioning in American tradition, Making the American Self: Jonathan Edwards to Abraham Lincoln (Oxford: Oxford University Press, 2009). Two recent works begin to tease out some of the latent tensions attendant upon young men, especially New Englanders, trying to express individual ambitions without violating imagined obligations imbued from the founders. See Glenn Wallach, Obedient Sons: The Discourse of Youth and Generations in American Culture, 1630-1860 (Amherst: University of Massachusetts Press, 1997) and J. M. Opal, Beyond the Farm: national Ambitions in Rural New England (Philadelphia: University of Pennsylvania Press, 2008).

${ }^{65}$ Although Learnard's family was struggling during this period, merchants in the northeastern United States were generally prosperous. See Pessen, Riches, Class, and Power, 47-51. According to Pessen, merchants were the chief class of the urban rich in antebellum America. Financial downturn did not signal departure from consideration as part of the middle ranks of antebellum society, however, for values played a distinguishing role in that social identity. See Rose, Victorian America and the Civil War, 11. Consult also Blumin on the role of values and social respectability in establishing middle-class status, 188-191. The ramifications of perceived failure in this period receive explication in Scott Sandage, Born Losers: A History of Failure in America (Cambridge: Harvard University Press, 2005). 
Noting that a new teacher was in town, he wrote, "[He] is a self-made man. He has dug his way through and quite a man too, I guess. . . Go ahead-you may yet be something in this unstable world is the wish of your poor father, who if he was able, would spare no expense to put you through."66 The elder Learnard's undisguised admiration for the new teacher, a "self-made man," sent a message to Oscar that this was a model his father would like him to follow. From his father's perspective, the man made himself who found his way without the traditional launch of a dutiful New England father. However, Oscar had no reason to doubt that they both understood other men might occasionally help fill that breech

Learnard's masculine associates uniformly recognized that uncertainty surrounded even the most diligent and talented young men still in the process of creating a foundation from which to build a successful life. The financial backing of fathers, brothers, and friends occasionally girded this activity. On the other hand, many from Learnard's cohort who anticipated the completion of collegiate or professional education expressed uncertainty about the funding of these endeavors. They took for granted-as did Learnard when lending his last five dollars to a temporarily destitute "brother attorney"-the expansive bounds of masculine fealty and occasional financial assistance of their male associates.

The "zealous desire of riches," as one cohort called obsession with wealth, is notably absent from the ambitions that Learnard's male companions claimed for themselves. This is not to say that they rejected profit-seeking, for many consistently scouted business opportunities wherever they went. Some may have obscured their true intentions, knowing others viewed overt greediness as evidence of unvirtuous character. True masculine success, however, was not ineluctably tied to financial accomplishment, at least at this stage in life. On the

\footnotetext{
${ }^{66}$ Tracy Learnard to Oscar Learnard, 7 September 1853, Oscar Learnard Papers, UKSRL.
} 
other hand, Learnard's friends uniformly sought college or professional training, and certain occupations, if pursued too long, identified them with failure in that respect. The list includes manual labor, such as farming or factory work, but also encompasses entry-level white-collar jobs like clerking or traveling sales. ${ }^{67}$ In another's direct employ, these young men might work diligently, but they always recognized the preeminence and appeal of the "high and important stations in business."

Unfortunately, not everyone with whom ambitious young men dealt had the kind of character that helped them fulfill their goals. The man who hoped to be successful remained alert to the designs of dishonest schemers. "Avoid evil company, warned the elder Learnard. "Admit no one to your friendship too hastily. The world is full of wolves in sheep's clothing." ${ }^{68}$ This was a lesson young Oscar learned for himself not long after leaving life as an academy student. Working for a time in the South as a traveling sales agent, he apparently extended his trust too quickly to another man, who then cheated him. "[T]he conclusion come to by all parties is, that Tom was a $\mathrm{d}$---d scoundrel and robbed you," Learnard's employer claimed. ${ }^{69}$ Learnard could see the value of a close network of friends whose loyalty was without doubt. The issue of whom to trust did not exist as long as Learnard kept his affairs closely tied to a network of men whose character, loyalty, and intentions were not in doubt.

\footnotetext{
${ }^{67}$ Stuart Blumin traces the evolution of distinctions between manual and nonmanual labor, and its special relevance to the nineteenth-century middle class in "The Hypothesis of Middle-Class Formation in Nineteenth-Century America: A Critique of Some Proposals," American Historical Review 90 (April 1985): 299-338. See esp. 313-18. Also see Brian P. Luskey, On the Make: Clerks and the Quest for Capital in Nineteenth-Century America (New York: New York University Press, 2010).

${ }^{68}$ Tracy Learnard to Oscar Learnard, 4 April 1853 and 7 September 1853, Oscar Learnard Papers, UKSRL. Antebellum advice literature warned young fellows at large to beware the "confidence man, who prowled the streets of American cities in search of innocent victims to deceive, dupe, and destroy." Halttunen, xiv.

${ }^{69}$ Alex Mackenzie to Oscar Learnard, 10 January 1853, Oscar Learnard Papers, UKSRL.
} 


\section{An "upright and manly course"}

By the time Learnard returned home from his stint as a salesman he was healthy enough to enter Norwich University, a Vermont military college modeled after West Point. The university was located only sixty miles south of Learnard's hometown of Bakersfield, but central ridges of the Green Mountains punctuate that distance, making direct travel difficult. However, other factors combined with distance to demonstrate to Learnard that he was entering a changed environment. College life lacked any comparison to the nurturing atmosphere that had marked his days at Bakersfield Academy, according to one friend. Accepting an increased responsibility for independence was necessary in college, he advised, especially for young men "about to enter upon the theater of action." His friend continued,

$[H]$ ere one meets the cold side of the world, which looks on with stoic indifference whatever may befall a man-there is not that sympathy which is a predominant characteristic of [academy] life, among a few chosen and confiding companions-where all have a common interest-here every man stands on his own foundation and all will try to throw him down-and accomplish their own aggrandizement upon the ruins of his demolished greatness-and there is nothing said-no such stewing as we had at [Bakersfield]. ${ }^{\text {,70 }}$

Greatness is exactly what all of Oscar's friends expected from him; he could ill afford to be ground down at Norwich.

A few hundred young men constituted the student body at Norwich University. Most were from New England, but some came from the West or South. The school was founded in 1820 by Vermont native Allen Partridge, former superintendent at West Point. Partridge had grown disgruntled with what he perceived as favoritism and unprofessional military standards, and decided to create a "Literary, Scientific and Military Academy" that could surpass West Point

\footnotetext{
${ }^{70}$ J. K. L. Maynard to Oscar Learnard, 25 March 1853, Oscar Learnard Papers, UKSRL.
} 
as a source for officers in the nation, men who would not be "ignorant of the first requirements of both military and every other Science." The Norwich catalog Oscar Learnard would have read also declared the special affinity of Norwich for "the young American," especially "when there is great demand for men, where a new country-new enterprises, new fields of useful and profitable employment are continually inviting the young and active." Strict military drill, dress, and discipline joined instruction in not only the classics, but applied science. The university's goal was to turn out well-rounded men prepared both physically and intellectually "to serve their country . . . in every employment that demands, strength, energy, and endurance.".71

Sleeping on wood slats, scrutinized and drilled daily, the Norwich cadets found themselves bound as much by shared hardship, as anything. Although he worked to succeed by merit, Learnard also linked interests with a few cadets to form a quasi-fraternity. As young men who chafed some under the university's policy of minute regulation, this coterie of cadets asserted their desire for independence in a clandestine organization they called "the Regulators." What they claimed they resented was not discipline or authority per se, but the deficient standards or characters they thought attended some of the faculty, cadets, and trustees to whom they were still required to show great outward respect. $^{72}$

The newsletter they subsequently issued "as needed" served as an organ for anonymously venting frustrations with faculty, trustees, and an occasional

${ }^{71}$ Catalog of the Corporation, Officers and Cadets of Norwich University (Montpelier, Vermont, 1853), American Antiquarian Society. On the move by midcentury to add instruction in science and utility to the usual classical course of college study, see Frederick Rudolph, The American College and University: A History, Rev. Ed. (Athens, Georgia: University of Georgia Press, 1990), Chapter Eleven; and "The Rise and Fall of Useful Knowledge: Higher Education for Science, Agriculture, and the Mechanic Arts, 1850-1875," in The American College in the Nineteenth Century, 153-168. The Partridge quotes are taken from Stephen E. Ambrose, Duty, Honor, Country: A History of West Point (Baltimore: Johns Hopkins University Press, 1999), 61.

${ }^{72}$ On the early history and conditions of Norwich University, see N. L. Sheldon, Norwich University (Reprinted from the New England Magazine, 1899). 
fellow student. Written to amuse as well as inform, The University Regulator declared "no apology necessary" for the group's intention to "regulate" Norwich because it and "vicinity require a good 'hauling over'." Its promoters explained that it was founded it to "exert a moral influence:"

The Regulator-whatever may be true of other papers-is not the organ of rowdyism, nor of that class of young 'swells' who, by their affected and ambitious verbosity, feign the man of importance,- - but it purports now as ever to express the feelings of those order-loving and honorable cadets, who, engaged in the culture of their natural power, have neither time nor inclination to indulge in vulgarity or license. ... Whenever the Faculty take a firm, decided, impartial course, they will find us their most zealous supporters; but when they take a weak, womanish course of threats without performance, or of child-like retaliation, they must not expect to escape the Regulator's lash. ${ }^{73}$

The editor and contributors wrote under fanciful noms de plume. Learnard contributed writing under the cognomen of "Chevalier James $\mathrm{H}$. Jerusalem" and also served as editor his last year at Norwich. ${ }^{74}$

Tensions between college students and officials or faculty were quite common in this period. Demonstrations by students protesting a tradition of "close control" led by midcentury in many institutions to their claiming "considerable autonomy" in an era marked by a general "unshackling of student life." Moreover, faculty often had little will to aggressively enforce strict disciplinary rules that could be holdovers from standards in place several decades earlier. The Regulators responded to these tensions, as well as the "tempered" expectations of faculty or

\footnotetext{
73 The University Regulator, 25 April 1854 and January, 1855, Oscar Learnard Papers, Kreitzberg Library, Norwich University.

${ }^{74}$ For a brief description of the Regulators, their purposes, habits, and members, see William Arba Ellis, Norwich University: Her history, her graduates, her roll of honor (Concord, New Hampshire: William Ellis, 1898 ), 56 and 465.
} 
performance of students, by humorously asserting their awareness of the hypocrisy that attended conditions at Norwich. ${ }^{75}$

Certainly, the clandestine organization served partly as a declaration of independence in men who soon might face their first period of full autonomy, but it also reminded readers that some of the cadets were truly serious about the education and skills Norwich was founded to provide. Many from the central core of the new organization were New England natives who afterward migrated to the West. Learnard, a k a "Jerusalem," and his cohort intended their experience at Norwich to build them into the kind of men who could become successful. Developing regions fairly begged for men with surveying, drafting, and engineering skills; discipline and order were valued by men of character everywhere.

The Regulators, though small in number, took resounding umbrage when they witnessed lackluster attitudes toward their education or training, even if they did so in tongue-in-cheek fashion. For example, the 1854 issue that Learnard edited carried this notice:

OBITUARY. Died in Norwich University, the $20^{\text {th }}$ of July, 1854 , of a lingering illness, Discipline, aged years. ... . Her death is mourned by numerous friends, and her loss can never be repaired.

In the same issue also appeared the following:

$\$ 10$ Reward-for the man who has seen the mathematical instruments of N. U. in operation. Report says there is a microscope, a level, a quadrant, a theodolite, \&c. \&c. Prof. Jackman, is it so? Can you claim the reward? ${ }^{76}$

\footnotetext{
${ }^{75}$ "College as it was in the Mid-Nineteenth Century," Roger Geiger with Julie Ann Bubolz, in The American College in the Nineteenth Century, 82-84; and also see Geiger's introduction, 9. Geiger and Bubolz also note the fairly widespread awareness of lighthearted student "memoirs" or "sketches" appearing during this period.

${ }^{76}$ The University Regulator, August, 1854, Oscar Learnard Papers, Kreitzberg Library, Norwich University.
} 
The Regulators functioned as a secret fraternity at an institution that in the 1850s disapproved of such societies existing on campus, potentially diluting its regulatory hegemony. More than that, it provided that sense of common purpose, high goals, and masculine fealty that Learnard found so appealing. It was also an atmosphere in which he thrived. The cadets who formed this clandestine organization discovered a way to rapidly bind young men together in cooperation, loyalty, and support in a setting much less forgiving than Learnard's beloved Bakersfield Academy. In the process, they also cemented social ties that lasted well beyond their years at Norwich, encouraged the pursuit of high goals while mitigating some of the negative effects of competition, and asserted their own value as men in comparison to some of the hypocritical or underperforming older men overseeing their education. ${ }^{77}$

Learnard's broader cohort generally admired the confident bearing that adhered to military cadets, and his probably increased after rubbing shoulders with scions from some prominent Northern and Southern families. Learnard's circle valued outward appearance as a signifier of inward character and important masculine qualities. ${ }^{78}$ The man of "gentlemanly deportment" who spoke and presented himself well, not courting the favor of others, garnered due respect. No seeker of attention, he also craved not applause-but neither did he shrink from challenge. He took up military pursuits proudly, learned to shoot straight, and appeared formidable in uniform. Not prone to aggressive displays, he sought consensus in problem-solving and disdained dueling. The successful

\footnotetext{
${ }^{77}$ Meeting in Chicago in the spring of 1860 , three of the founding members of the Regulators drew up a resolution to their constitution calling for all former members to gather at Norwich that fall to commemorate "the time of jubilee eight years ago set apart for our observance." Learnard was one of three signing the resolution, although in the true spirit of the secret organization, his name appears as "Chevalier James H. Jerusalem." See document fragment, Oscar Learnard Papers, Kreitzberg Library, Norwich University.

${ }^{78}$ By midcentury, outward signs of respectability had gained considerable currency in the assessment of character. Consequently, "[i]ndividuals grew accustomed to presenting themselves for public appraisal." See Kasson, 7 and 24.
} 
man "elevated" the general condition of not only himself, but those around him. ${ }^{79}$ Steadfast and independent, he stood prepared, when necessary, to aid family and friends.

Most of all, however, the successful man did not disappoint other men. Precisely, he embodied their conceptions of honorable masculine conduct. He could model successful behavior even in the midst of failure, and so maintain his claim to respect. Learnard's father, losing his first political contest, received assurance from his son that this was indeed the case. "I am sorry that you have met with a defeat when just entering upon the arena of politics," wrote Learnard, "but you can console yourself with the fact that this has almost universally been the lot of great men." 80 One cohort advised Learnard similarly: "[l]nstead of yielding to the bickerings of fortune, walk boldly forth in the path of duty and endeavor to overcome the petty vexations of life by an upright and manly course." ${ }^{181} \mathrm{~A}$ man of true substance interpreted defeat as a challenge to keep trying, but he was also aware that his behavior impacted those connected to him. Learnard confirmed this when he wrote to his father, "You have a right to, and may expect of me, that I shall do nothing to bring dishonor upon myself or sorrow to you." 82 In Learnard's most intimate circle, to behave otherwise was selfindulgent and ungrateful.

Even the most determined among them occasionally bent under the weight of others' expectations, however. For Learnard, this moment of selfconscious vulnerability came while battling boredom and isolation as a new lawyer in rural Ohio:

\footnotetext{
${ }^{79}$ Tracy Learnard to Oscar Learnard, 4 April 1852, Oscar Learnard Papers, UKSRL.

${ }^{80}$ Oscar Learnard to Tracy Learnard, 21 September 1853, Oscar Learnard Papers, UKSRL.

${ }^{81}$ John Maynard to Oscar Learnard, 21 March 1853, Oscar Learnard Papers, UKSRL.

${ }^{82}$ Oscar Learnard to Tracy Learnard, 26 April 1852, Oscar Learnard Papers, UKSRL.
} 
For a while my ambition was gone, and my aims and hopes seemed to here sink away with a quiet willingness, almost a wish, to live under the clear sky and amid the rugged steeps of my native home. But I had concluded to go--I had promised myself to make an honest endeavor to accomplish something worthy, while kind friends were cherishing hopes of me which I must strive to fulfill--at least not crush for want of an effort on my part. ${ }^{83}$

The man of honor owed a debt to himself and those close to him to live up to his abilities. Learnard's coterie may have surrounded and protected him, but these ambitious young men also acknowledged his superior talents and demanded that one so honored among their group must not let them—or himself-down. Of this, Learnard was acutely aware. In a moment of candor, he wrote, "I may frankly acknowledge that my ambition for worldly distinction and success is a good deal abated and that this expectation of my friends is one of the chief incentives for me to strive for them, and I am not willing that any consolation I can afford in this way shall be lost to them. ${ }^{184}$

Notable occupations, respectability, and loyalty to the expectations of masculine associates: these traits distinguished the successful man. ${ }^{85}$ Learnard's companions knew that among those who attained this status, some would be more self-made than others. Regarding their relations to each other, this was of little consequence. The only issue before them was meeting the goal. By supporting each other thoroughly and assisting each other when necessary, they downplayed individual accomplishment. These young men were not concerned with being self-made; they were making each other.

\footnotetext{
${ }^{83}$ Oscar Learnard to "Dear Friends," 17 May (n.d.), Oscar Learnard Papers, UKSRL.

${ }^{84}$ Ibid.

${ }^{85}$ "Public evaluation," the source of nineteenth-century respectability, is the central element of honor, according to Wyatt-Brown. In the antebellum North, respectability meant "domestic and civic virtue." See pages 14 and 20.
} 


\section{Bleeding Kansas: "I am not alone"}

The 1854 Kansas-Nebraska Act sent Northerners and Southerners alike scurrying to opposite sides of an imaginary line in the sand, heels dug in for the impending intense battle over slavery's potential extension. Settlers began arriving in Kansas Territory almost immediately, pouring in from Missouri and the Old Northwest, mostly without incident. Soon, however, rumors began swirling through Missouri that wealthy Eastern corporations, known as emigrant aid companies, were sending "armies of hirelings" to dominate the territory and sway elections in favor of slavery's non-extension. Secret defensive societies formed in western Missouri with names that attested to the fraternal and associative nature of early regional alignments: Blue Lodges, Social Bands, Friendly Societies, and Sons of the South. ${ }^{86}$ By 1855 , scores of settlers and hopeful speculators had poured into the eastern portion of Kansas Territory from all directions. Many found that much of the region had been quickly dotted with claims hurriedly staked by Missouri "settlers," many of whom entered Kansas only periodically to sway election outcomes with fraudulent votes or try to harass Eastern claimants off acreage now in dispute. The inevitable early conflicts actually sprang from mixed beginnings. Land hunger mingled with cultural or sectional mistrust that was only inflamed by the high pitch of interest increasingly emanating from the states.

Learnard had been in Kansas Territory only a short time before he was defending himself, but not in relation to the territorial squabble. His father had charged him with instability, and he had a reasonable concern. What was a young professional man like Oscar, who was not an "abolitionist fanatic," doing at the epicenter of this national maelstrom: first Tennessee, then Ohio, and now

\footnotetext{
${ }^{86}$ The role organized emigration played in escalating border tensions is described in Samuel A. Johnson, "The Emigrant Aid Company in the Kansas Conflict," Kansas Historical Quarterly 6:1 (February 1937), 21-33. The current standard work on Bleeding Kansas is Nicole Etcheson, Bleeding Kansas: Contested Liberty in the Civil War Era (Lawrence, Kansas: University Press of Kansas, 2004).
} 
this? Oscar rehearsed his reasoning: Tennessee had been for the benefit of health; the law office in Ohio was not promisingly located. He had been in lowa, scouting prospects, and got the chance to go to Kansas at "trifling expense," which in this case meant alone, on horseback. He would hate not seeing this region, too, when he had the chance..$^{87}$

Learnard informed his family that he was "keeping house" with an old Vermont friend who had staked some acreage just outside Lawrence. Together they quietly passed a winter so severe that it stifled all regional tensions for a few months. He also speculated on some land of his own and worked alongside his friend when farm chores returned with the spring thaw. He never saw a place more likely to bring "unrivaled opportunities" to investors. ${ }^{88}$ "We have in Kansas a country of unsurpassed beauty and advantage," he wrote his family, noting that he became "more attached every day." ${ }^{89}$ Learnard indicated that he still might return to lowa, though, and perhaps visit Vermont, but his funds were tied up in Kansas property for the time being. Besides, titles were not certain until the official market opened for land.

Events of that spring and summer, however, prevented much progress toward staking out claims. Clashes between Free-State and proslavery factions-just breaking out in earnest when Learnard arrived-escalated by spring of 1856 to the full civil war of Bleeding Kansas.

Learnard aligned himself with the Free-State element headquartered in Lawrence, which many then called Yankee Town. The culture already formed in that new community made Learnard feel himself almost back in New England. "I

\footnotetext{
${ }^{87}$ Oscar Learnard to Tracy Learnard, 8 April 1856, Oscar Learnard Papers, UKSRL.

${ }^{88}$ Oscar Learnard to "My Dear Parents and Sister," 6 April 1856 ; and to "Dear Friends," 9 Sept 1856, Oscar Learnard Papers, UKSRL.

${ }^{89}$ Oscar Learnard to Tracy, Polly, and Amanda Learnard, 17 June 1856, Oscar Learnard Papers, UKSRL.
} 
can hardly realize that I am so far away," he wrote, ". . . as most of the inhabitants are from Yankee land, which gives such familiar air to things, unknown in most western towns." Indeed, one Kansas settler noted that it was Lawrence's reputation as a concentration of New Englanders that fueled the determination of Missouri migrants to repeatedly disrupt settlers in that vicinity. ${ }^{90}$ The town's New England roots are evident also in some of the other names by which it was briefly called or which were suggested: New Boston, Sumner after the Massachusetts senator, and finally Lawrence, in honor of Amos A. Lawrence, a prominent Massachusetts force behind the New England Emigrant Aid Society. $^{91}$

Some nineteenth-century observers claimed that "'wherever two or three Yankees are met together there they hold a meeting and organize."' Indeed, the new inhabitants of Lawrence, which was really a glorified collection of "hay tents" of varying sizes for the first year or two, created institutions almost as quickly as they laid their claims to land. Almost immediately, they laid out their town with a main street named "Massachusetts," created ad hoc "laws" in the absence of any other ruling government, and elected officials. In rapid succession also appeared numerous schools, churches, and newspapers, even if most of these operated from "buildings" normally used for other purposes. However, by early 1856, the New England Emigrant Aid Society had erected a comfortable and fortress-like three-story stone hotel, the crowning glory of a town that seemed destined for rapid expansion. ${ }^{92}$

${ }^{90}$ Oscar Learnard to Tracy, Polly, and Amanda Learnard, 6 April 1856, Oscar Learnard Papers, UKSRL. Also see the Lewis Timothy Litchfield Diary, UKSRL.

91 "Lawrence: a Glance at its History," in Neosho County Record, 7 April 1877, clipping in Douglas County Clippings, Vol 1, 1855-1881, Kansas State Historical Society; and "Leis' Reminiscences of Old-Time Lawrence," in Lawrence Journal-World, 21 September 1915, clipping in Kansas Scrap-book, Biographical HeHi Clippings, Vol 11, Kansas State Historical Society. Very briefly at the beginning of settlement, some called Lawrence by the name Wakarusa, the original name of the general region..

92 The most detailed history of early Lawrence is probably Richard Cordley, Lawrence, Kansas: The First Settlement to the Close of the Rebellion (Lawrence, Kansas: E. F. Caldwell, 1895). The quotation is from pages 6-7. 
It is clear that those of New England ancestry who made up the majority of the early inhabitants of the Lawrence region intended to reproduce much of the culture of their heritage. The first funeral was observed "'in our New England way." Soon after arriving, some women set about replicating New Englanders' beloved Thanksgiving with what provisions were available. In fact, Learnard himself dined alongside the Free-State movement's elected leader, Charles Robinson, at one early Thanksgiving feast hosted by former Vermonters. The first Congregational church-itself a New England cultural staple-adapted its creed and constitution from a Boston church. In fact, congregants "voted to name it Plymouth Church on account of the close parallel between the Kansas settlers and the pilgrims at Plymouth., ${ }^{93}$

That comparison is one that was drilled into the consciousness of settlers when they gathered, as they often did, and together sang Whittier's "Hymn of the Kansas Emigrant." Whittier composed the song to proclaim and honor the nobility of the emigrants' mission. Its first performance in Boston at an early send-off rally for Emigrant Aid Society migrants was accompanied by a handful of them who were taking their instruments to Kansas, two Vermonters prominent among them. The song quickly became a sort of national anthem to Eastern emigrants, especially those who settled in the Lawrence area. Sung to the tune of "Auld Lang Syne," it celebrates the Kansas emigrants' New England heritage:

We cross the prairie as of old

The fathers crossed the sea

To make the West, as they the East

The homestead of the free.

\footnotetext{
${ }^{93}$ Ibid., 16-17; and "Woman Who Could Cook 'Saved' First Lawrence Settlement," in the Kansas City Star, 10 October 1929 , clipping in Kansas Scrap-book, Biographical He-Hi, Clippings Vol. 11, Kansas State Historical Society. While Learnard may have celebrated Thanksgiving with the Savage family of Vermont migrants, as their daughter much later reported to the Star, it was probably in the fall of 1855 , not 1854 . Learnard did not arrive until the latter part of 1855 .
} 
Other verses esteem the "mother land" and its "native hills," and in other ways verify the intention to transplant New England cultural values. Verse four, for example, celebrates New England's reputation for advancing the cause of public education:

We go to plant the common school

On distant prairie swells

And give the Sabbath of the wilds

The music of her bells. ${ }^{94}$

Despite being despised by proslaveryites as a supposed "abolitionist stronghold" and destination of emigrant aid settlers, Lawrence mostly contained a variety of ambitious and reasonable men who respected governmental authority. ${ }^{95}$ Learnard was certainly not an abolitionist. Working in Tennessee two years earlier, he remarked on his lack of sympathy for "human cattle" facing auction there: "They all seem to be better off than myself, so I do not mourn over them much." ${ }^{96}$ The Free-Staters in Lawrence were, Learnard later recalled, "men whose former party predilections and affiliations were largely dissimilar, often antagonistic, [who] strove together loyally and faithfully until victory was assured." ${ }^{197}$ Settlers in Lawrence and the surrounding region were drawn together rapidly on terms of intimacy and loyalty by a shared perception of impending danger, abuse, and hardship. Refusing to recognize territorial laws passed by what they considered a "bogus legislature," most learned to avoid disputes or

\footnotetext{
${ }^{94}$ Cordley, 7-8.

${ }^{95}$ Burton J. Williams, "Erastus D. Ladd's Description of the Lawrence Massacre," Kansas Historical Quarterly 29:2 (Summer 1963), 113-121. According to Nicole Etcheson, "Only a minority of the free-state movement. . . can be considered abolitionists." See Nicole Etcheson, 5.

${ }^{96}$ Oscar Learnard to Tracy Learnard, 21 June 1852, Oscar Learnard Papers, UKSRL.

97"Organization of the Republican Party: An Address by O. E. Learnard before the Republican Editorial Association of the Second Congressional District, at Osawatomie, May 18, 1898," Oscar Learnard Papers, Kansas State Historical Society.
} 
resolve them amicably outside the territorial courts. Among themselves, they felt "'under bonds to keep the peace'". 98

This was not an abolitionist assembly, although a few among them were strong abolitionists. For the most part, the fight against slavery's extension into Kansas united Free-State men of varying ideological backgrounds whose primary concern was the non-extension of slavery and the rightful expression of their republican liberties. ${ }^{99}$ No hotheaded fanatics, they worked in concert, by consensus, with long-range common goals in mind, despite their differences. For the most part, they were gentlemen, in spite of the crude surroundings. One observer claimed

It was no uncommon thing to find college graduates driving an ox team through the streets of Lawrence, or cutting timber by the river, or living in some lonely shanty or dug-out. Not in towns alone, but on claims all around, you would find the same class of people. In the loneliest cabins in the most out of the way place, you might find men who could talk to you intelligently of the latest scientific theory, or discuss the latest novel. As a rule, they were peaceable men ...

Despite the fact that there were a few "rough and turbulent characters among them" who occasionally did "rash and wrong things," the core of settlers in the Lawrence region managed themselves in a remarkably orderly fashion. Familiar with masculine relations conducted in this manner, Learnard fit right in. More and more, he began to write of "our men" in Kansas and the injustice afflicted on "our unoffending heads. ${ }^{\text {"100 }}$

Named Lieutenant Colonel of a volunteer Free-State cavalry regiment, Learnard felt even more connected to the contest for Kansas soil. For one thing,

\footnotetext{
${ }^{98}$ Cordley, 83-84.

${ }^{99}$ On the central connection of republicanism to the Kansas conflict, see Etcheson, Bleeding Kansas and Michael F. Holt, The Political Crisis of the 1850s (New York: W. W. Norton and Company, 1978), chapter seven.

${ }^{100}$ Oscar Learnard to "Dear Friends," 6 June 1856 and Oscar Learnard to Tracy, Polly, and Amanda Learnard, 17 June 1856, Oscar Learnard Papers, UKSRL.
} 
that assignment positioned him directly beneath the two acknowledged leaders of the Free-State movement, Charles Robinson and James Lane. Moreover, Learnard liked being active, vitally involved and "constantly employed, not for pecuniary gain, but preparing for emergencies." ${ }^{101}$ Learnard slept on the ground, lived in the saddle. "Yet I do not complain," he wrote. ${ }^{102}$ Military college had prepared Learnard for hardship and duty, and at least this was no deserted law office in a sleepy Ohio town.

"Stirring times" that summer provoked a rise in sentiment, reflected in the letters Learnard sent home. ${ }^{103}$ If forces claiming jurisdiction illegitimately threatened Free-Staters again, "even the color of 'authority' shall not shield them from the vengeance of an outraged people," he vowed. Learnard now identified with "the people," and he knew no better way to express the brave heritage of his noble state than to fully embrace the republican cause. ${ }^{104}$ Real men would do no less, nor would they allow as their "self-appointed masters" the "old neighbors, in many cases friends," who had lately lived beside some of them in Missouri. As one "long accustomed to civic and social restraints," Learnard was appalled at the rule of physical force, and especially the "lawless disposition" of "frontiersmen." ${ }^{105}$ Honorable, respectable, forward-looking men could not thrive under such individualistic conditions, nor should they tolerate them. Learnard and his present masculine associates, his Free-State cohorts, did not intend to do so.

\footnotetext{
${ }^{101}$ Oscar Learnard to Tracy Learnard, 29 May 1856, Oscar Learnard Papers, UKSRL. Idleness was associated with uselessness in traditional New England thinking. See Wilson, Ye Heart of a Man.

${ }^{102}$ Oscar Learnard to "Dear Friends," 9 Sept 1856, Oscar Learnard Papers, UKSRL.

${ }^{103}$ Oscar Learnard to Tracy Learnard, 3 September 1856, Oscar Learnard Papers, UKSRL.

${ }^{104}$ Oscar Learnard to Tracy Learnard, 10 August 1856. Oscar Learnard Papers, UKSRL. According to Thomas Bender, patriotic notions of nationalism at midcentury existed mainly as abstractions, finding truest expression, as the case of Bleeding Kansas illustrates, in local communities. See Thomas Bender, Community and Social Change in America (New Brunswick, New Jersey: Rutgers University Press, 1978), 88.

${ }^{105}$ Oscar Learnard to Tracy, Polly, and Amanda Learnard, April 6 1856, Oscar Learnard Papers, UKSRL. W. Eugene Hollon notes the general tendency toward violence in American borderlands in Frontier Violence: Another Look (New York: Oxford University Press, 1974), Chapter Two.
} 
When the fighting finally died down and titles were more secure, men returned their full attention to the reason most of them had come to Kansas in the first place: land. Almost immediately, Learnard partnered with some other New Englanders, Vermonters salient among them, to found a town about fifty miles south of Lawrence, where Learnard had a claim. Named after a notable Vermont city, Burlington was not one of the myriad "paper towns" that existed in theory in booming frontier regions, but never materialized. In fact, due to Learnard's energetic oversight, partly illustrated by his seeing to the rapid construction of a nascent business district, the town quickly prospered. ${ }^{106}$

Learnard found in Kansas Territory the kind of atmosphere in which a man such as himself could to rise to prominence. His training at Norwich University made him an invaluable military leader. He was surrounded mostly by other relatively young men, his peers, the very population with whom he operated most successfully and among whom he usually shone. Most of them understood each other. They came for land, for the main chance, and were comfortable surrounded by a significant number of Yankees. Learnard and his Free-State cohort were determined to place their own cultural stamp on the region before proslaveryites could get the upper hand. Small wonder, then, that when Learnard presided over the convention that formed the Kansas Repulican Party 1859, he was a mere twenty-six years old. By then, the battle over rights and liberties, and for Kansas' future, had moved from the man-to-man combat of Bleeding Kansas and into the national political realm. ${ }^{107}$

\footnotetext{
${ }^{106}$ A biographical fragment in the Oscar Learnard papers notes that Learnard erected in Burlington the first mill, first "business house," and also the first "building for church and school purposes." UKSRL. The law incorporating the Burlington Town Company appears in The Laws of the Territory of Kansas passed January 12, 1857 (Lecompton: Kansas Territory, 1857), 277. On the founding of Burlington and surrounding region, also see Coffey County, Vol. 1, Wanda Christy, Ed. (Coffey County: June 1987), 36-37. The reference to "paper towns" is on page 25.

107 "Organization of the Republican Party: An Address by O. E. Learnard before the Republican Editorial Association of the Second Congressional District, at Osawatomie, May 18, 1898," Oscar Learnard Papers, Kansas State Historical Society.
} 
A half-century later, an elderly Oscar Learnard was still fighting, only now the contest was over the legacy of John Brown. Addressing his fellow "fiftysixers" in Lawrence in 1910, he decried the elevation of Brown that "perverted" historical memory, and was there to "repudiate and deny" recent claims that Brown was "the savior of Kansas." ${ }^{108}$ Learnard bolstered his contrary assertions with the carefully documented or previously published statements of eye witnesses.

For Learnard, however, the effectiveness of John Brown in the fight for Kansas freedom was no more at issue than his character and the nature of his masculine associations. Remarkably, the Pottawatomie Massacre, for which Brown achieved national notoriety, received small attention from Learnard, although he noted that any butcher so slaughtering livestock would be promptly jailed. Rather, Brown's untrustworthiness and conduct in general demonstrated that this son of New England did not reflect Learnard's conception of respectable manhood formed there among Learnard's father and friends.

Off and on during the Kansas hostilities, Learnard was able to observe or interact with Brown, especially during the summer of 1856 as hostilities really heated up. Learnard claims Brown earlier had represented himself falsely as a veteran soldier, prompting Lane and Robinson to grant Brown the "nominal command of a small squad of men." Before long, however, Learnard's opinion of Brown was so low that he refused Lane's request to allow Brown to accompany Learnard's regiment on one particular mission. Indeed, Brown's "habit of growling and fault-finding" with Free-State allies, otherwise known for their harmonious

\footnotetext{
${ }^{108}$ Oscar E. Learnard, "John Brown of Kansas," Confederate Veteran, Vol. 19 (1911), 58. Oscar Learnard Papers, Kansas State Historical Society.
} 
associations, got him booted from at least one camp of Free-State defenders, said Learnard. ${ }^{109}$

Not prone to accepting orders, Brown also eventually plundered the property of anyone who crossed him and ambushed unsuspecting victims with "forays" and "night alarms," according to Learnard. Such insubordination and unpredictable vigilantism flew in the face of everything Learnard had learned about military discipline and its role in restoring peace. In fact, Norwich University had insisted that its program, although military in form, did not turn its cadets into "lovers of war:"

They cultivate peace, they promote peace by acquiring the ability to defend themselves or others on proper occasions. They themselves learn to observe the rules of good order and to respect the rights of others, while they know what their own rights are and how to defend them. ${ }^{110}$

Entirely contrary, Brown's activities left the border counties ruled by "disquiet and apprehension" until Brown departed Kansas for good, according to Learnard. He was a "loafer," a "brawler," and a "disturber" who "scattered misery with the hand of a sower," killing men who posed no immediate threat to his safety. ${ }^{111}$ Brown epitomized the individualistic lawlessness that had so shocked Learnard in frontier Kansas, where reasonable men working together did not hold the balance of power temporarily, and chaos reigned.

109 Ibid., 58-59; and "Leis' Reminiscences of Old-Time Lawrence," in Lawrence Journal-World, 21 September 1915, clipping in Kansas Scrap-book, Biographical He-Hi Clippings, Vol 11, Kansas State Historical Society; and 'John Brown of Kansas: a Paper read before the Annual Meeting of the 'Veterans of 56' on September 14, 1910, by Col. O. E. Learnard," in The (Lawrence) Jeffersonian-Gazette, 21 September 1910 , clipping in the Oscar Learnard Papers, UKSRL.

${ }^{110}$ Catalog of the Corporation, Officers and Cadets of Norwich University (Montpelier, 1851-2).

${ }^{111}$ Ibid., 58-9. Mark Kann describes the social dangers thought to adhere to "intramale conflict" at the time of the founders: "[D]isorderly men threatened to destroy fraternal unity by acting on 'unmanly ambition' to upset individual lives, destroy families, and ruin social harmony." A Republic of Men: The American Founders, Gendered Language, and Patriarchal Politics (New York: New York University Press, 1998), 105. New Englanders traditionally took very negative views of attacks perpetrated on men while situated upon their own property, such as occurred in the Pottawatomie Massacre. See Lombard, Chapter Five. 
There was more proof of Brown's disrepute, however. "To know the character of the man fully," advised Learnard, examine the pattern of his life. Brown was, he said, a "disappointed, disgruntled, distempered, misanthropel, bankrupt in business and in reputation." Brown's biographers often do not disagree with that assessment. He was, as Learnard asserted, delinquent in business transactions throughout the northeast, dragged into court in six states, and had defied the law on one occasion with shotguns, barricaded in a farmhouse. These facts alone would be enough to discredit Brown with Oscar Learnard, and probably any one of the men from his circle. If there was a leitmotif to their correspondence, it was the necessity of working through established masculine networks, not against them. Brown, on the other hand, was stubbornly and arrogantly self-reliant, refusing all advice and seeking no counsel. It was his downfall in business, and the source of Learnard's scorn. ${ }^{112}$

Despite the "spittle of effulgent adulation" "habitually spread upon his memory," Brown was in no way a credit to Kansas, claimed Learnard. Quoting an editorial from the Topeka Capital, he added, "There is not written in the annuals of Kansas a single incident that reflects credit upon the intelligence of John Brown, his industry, his integrity, or reveals a single admirable quality of heart or mind." Intelligence, industry, integrity--how close Learnard comes to summarizing those very qualities of success formulated within his circle of male companions: notable occupations, respectability, and loyalty to the expectations of masculine associates. Unlike Learnard, a 'builder" of Kansas, Brown had never been a citizen in the true sense, held no "legitimate business or employment" there, and brought no "improvement or development" to it. ${ }^{113}$ In other words, in Kansas, Brown lacked the qualities of successful manhood as determined by his relation

\footnotetext{
${ }^{112} \mathrm{Ibid}$., 59. Brown was not purposefully dishonest in his business dealings, just stubborn, arrogant, and incompetent, according to Oates, To Purge this Land with Blood. On the impetus Brown's business impotence provided for his developing identity with blacks, see John Stauffer, The Black Hearts of Men: Radical Abolitionists and the Transformation of Race (Cambridge, Massachusetts: Harvard University Press, 2002).

${ }^{113}$ Learnard, "John Brown of Kansas," 60.
} 
to a developing environment. After a half-century, in Learnard's estimation, Brown's legacy was determined not only by his being a fanatical revolutionary. Brown was condemned partly on the basis of being a failure.

\section{Conclusion}

Oscar Learnard was the kind of young man who seemed somewhat adrift unless he had a clear focus and purpose in life. It was ultimately the source of some concern on the part of his father, who nervously awaited firm evidence of Oscar's successful launch into full adulthood. ${ }^{114}$ However, although Oscar's endeavors and locations changed periodically, he never lost sight of his primary goal, which was to become a respectable man who was also well-placed enough to provide for his aging parents and sister, if necessary.

In the educational settings of Bakersfield Academy and Norwich University, Learnard came into his own as a young man of superior ambition and ability. Even his friends claimed Learnard was destined to greatness based on their evaluations of him. However, it was also in those settings that Learnard's closest male companions fashioned models for cooperation and loyalty, even as they knew they also competed for scholarly honors.

At Bakersfield, for example, Learnard helped found-with a few of his male friends-an oratorical society they named the "Sons of Elocution." They elected Learnard secretary, so the constitution and records are in his hand. He

${ }^{114}$ Oscar's father may have also worried that his son seemed reluctant to marry, as well as settle down. Along with defending against his father's "charge of instability" in his letter of April 8, 1856, Oscar notes: "The 'snug little home' and 'nice little wife' I intend shall be forthcoming." Bachelorhood also carried negative connotations for achieving true manhood status in traditional New England thinking. At this point, Oscar already knew the Lawrence family whose daughter he later married, but "forthcoming" turned out to mean six years later. Either Oscar's intentions to marry in the general time frame of his 1856 letter fell through or he spoke in abstract terms of his general intentions in life. On the potential for bachelorhood to carry negative connotations for achieving full manhood status see John Gilbert McCurdy, Citizen Bachelors: Manhood and the Creation of the United States (Ithaca, New York: Cornell University Press, 2009); Foster, Chapters One and Five; Lombard, 55-69 and 76-79. 
records therein their reason for organizing: elocution was "of paramount interest to the young man in every deportment of life." Learnard and his chums did not leave to chance that they could master this skill through classroom work alone. Similar to so many nineteenth-century Northerners, they were joiners and organizers of associations. The "Sons of Elocution" first "pledged" themselves to "sustain order and also to subject regulations to the decisions of a majority of the members present." Furthermore, they agreed to rotate the role of acting chairman. Committees determined the subjects of each oration. During the "exercise" members were allowed to "suggest" their own opinions "in an orderly manner." Membership comprised accession to the club's by-laws, a favorable vote from current members, and payment of a small "tax" levied on members to defray expenses. Central to the harmonious functioning of the little group was their dedication to problem solving through consensus and cooperation. Through the negotiation and enforcement of these little measures, Learnard and his fellow society members rehearsed the arranging and rearranging of roles and status.

Despite the fact that no one, certainly not teachers or parents, was likely to object to the coterie spending their time improving their speech-making skills, the "Sons" decided to operate in privacy as much as possible. Toward that end, they devised a password, assigned a committee to act as "doorkeepers," and designed a special "badge" that was "emblematic" of their purpose. These activities testified to their growing awareness of approaching adulthood and the independency from outside authority that must soon attend it.

In organizations such as the "Sons" and later the Norwich "Regulators," Learnard and his closest companions drew into a closed world of peers where they could manage their relations to each other and test those that resided outside. Without rebelling against the values that school officials or parents promoted, they added a form of horizontal evaluation to the top-down one that already existed, but which resided in an unstructured American educational 
system with expectations and grading far from standardized. ${ }^{115}$ Occasionally uncertain of the necessity to acquiesce to opinions of school officials, Learnard's friends created a space for themselves where they could encourage each other to practice the manly art of self-direction in the noble pursuit of success. Learnard demonstrated as much when he revealed his idealization of masculine friendship as part of a much longer poem published in The Regulator:

A throng of generous hearted brothers,

Strong in friendship, high in aim,

Striving, with a manly valor,

To acquire an honest fame. ${ }^{116}$

Despite the self-confidence Learnard exhibited in school settings, in the "real" world between school stints he was often unsure of himself. Where should he go; what should he do? Some of that confusion grew from the uncertainty of health, and what many in the nineteenth century believed was the destructive role of hard study upon it. Testing independence temporarily as a sales agent or clerk only convinced Learnard that he wanted more, and that education was the key to achieving it. Moreover, away from school, Learnard found himself absent the constant admiration and approval that came from daily contact with a close cohort with whom he shared the experience and purpose of identifying as a group.

Learnard could have found appropriate affordable land and settled in any number of places. Indeed, he talked to the family about their all relocating to the South, or Ohio, even before Learnard decided to investigate lowa, and later also Kansas. What kept him in Kansas was again finding purpose and feeling

\footnotetext{
${ }^{115}$ Hessinger notes that, lacking a clear form of professionalism until later in the century, sometimes teachers' "ability to judge students fairly or accurately was vulnerable to doubt." See page 94.

${ }^{116}$ The University Regulator, April 1855, Oscar Learnard Papers, Kreitzberg Library, Norwich University, Northfield, Vermont.
} 
cohesion with others-primarily men-in pursuing that purpose. Where he had "played" soldier at military college, in Kansas he could actually put those skills to valuable use. Learnard had been groomed for leadership in all his academic settings-academy, military college, and legal training — and in Kansas he finally found a ready outlet for all that preparation. There, he found not only the land and financial security he went scouting for, but a strong sense of purpose. Eventually, he also discovered the fulfillment of what his friends had always said they expected from him—great things.

In Learnard's perception, the elevation of the Kansas land struggle to civil war status in the summer of 1856 lifted his activities there to the level of sacred duty. His rapid identification with the New Englanders in the vicinity of Lawrence certainly contributed to that sense of shared crisis and purpose. Too often, John Brown acted contrary to those of the "respectable element" of the Free-State men in pursuit of his own idea of sacred duty. This convinced many of them that Brown was never an appropriate man to represent the interests of Kansas, not at the time, and certainly not in perpetuity. Similar to how Learnard stepped forward in the 1850 s as a leader in that "respectable element" of Kansas men, he also stepped forward decades later to combat Brown's elevation to saint and martyr status as the supposed "savior of Kansas."

Learnard formulated his conceptions of successful manhood before coming to Kansas. The men of his coterie encouraged each other and sought protection from the vagaries of life in the closeness of their connections. Through cooperation, they sought to offset the uncertainties inherent in the nineteenthcentury marketplace. Career anxieties were not their only bond, however, for they formulated much of their code of masculine conduct while many were students working through the challenges of health, education, romance, and the meaning of New England background to an ambitious young man's life. Learnard 
carried this foundation with him as he ventured westward, eventually into Bleeding Kansas.

The war for Kansas freedom was also a contest for an acceptable code of masculine conduct." ${ }^{117}$ Fraternal ties forged in New England anchored Oscar Learnard and guided him through this precarious environment. The sense of masculine commonality that mitigates the effects of competition, so elusive to John Brown, served Learnard well in Bleeding Kansas. The regularity of male association he relied on was again available to him, bringing a sense of order and acceptance to his life-by all accounts a very successful one.

\footnotetext{
${ }^{117}$ Kristen Tegtmeier Oertel notes that the "ideal types of Northern and Southern manhood" seldom "coincided with lived experience, especially in frontier Kansas where sectional violence and lawlessness punctuated settlers' daily lives. See "'The Free Sons of the North' versus 'The Myrmidons of Border Ruffianism': What Makes a Man in Bleeding Kansas?" Kansas History: A Journal of the Central Plains 25 (Autumn 2002), 176.
} 


\section{CONCLUSION}

The heady atmosphere of raw opportunity in the emerging West of the early republic only increased the likelihood that young men could act on the fact that fathers or other male relatives were less and less likely to assert control over their lives. They had choices. They were more free to choose occupations and to select whom to marry and when. They conceivably could take more credit for their successes. What some of them found hard to swallow was that they were also potentially more culpable when the result of their choices was failure. Balancing the tensions between choice and direction or credit and blame often complicated male relationships.

Take the case of Edward Fitch. In 1852, Edward was the twenty-three-yearold son of a tired municipal judge who was nearing seventy. Before Edward left home, Luther Fitch's Portland, Maine, household included, in addition to his wife and a couple of non-family residents, nine grown or near-grown children, one sonin-law, and two grandchildren. If any man should have been thankful that New England traditions had waned requiring fathers to fund or secure livelihoods for their sons, it would be Luther Fitch. ${ }^{1}$

Edward, however, had other ideas. Seeking success in the Chicago area in the early 1850 s, he continually faulted his father for withholding money and letting Edward's dreams - and other men—pass him by. It began when Luther neglected to fulfill his son's request to send a new suit of clothes. Edward writes, "If I have to stay in the house because I have no decent clothes to wear you must not expect me to obtain employment." His requests for aid continued, and escalated:

If I had money as I have always told you, I could do something but without it is no use trying. There are numbers of young men here doing nothing and waiting for chances for employment. ... There are

\footnotetext{
${ }^{1}$ See the Edward Fitch Papers, Newberry Library.
} 
always opportunities for doing business here if a person has means but without the chances are small indeed. ... . So for mercies sake send me means and let me do something if possible for I am ashamed of myself for doing nothing for such a long time. ${ }^{2}$

Edward's letters to his father continued in this vein for two years, despite his father's frequent reminders that he was "drained of money." It seems Edward never tired of reminding his father that he expected to be placed into a situation by which he could eventually make his own way.

Edward Fitch's letters were not typical; in fact, they were far from it. Most Western migrants of Yankee origins treated their fathers with a great deal more respect. Most of them also had too much pride to make such blatant and persistent overtures for substantial aid. However, Edward's unusual bluntness demonstrates with remarkable clarity that traditional expectations regarding a father's aid had not entirely died. Edward's letters highlight the uncertainty that accompanied a Western venture, and the frustration that often resulted.

By the 1850s, it seemed Americans universally admired the idea of a selfmade man, one who supposedly succeeded despite adversity, and on his own merits. Apparently it was not a status to which Edward Fitch aspired. It was, however, one that Oscar Learnard's father embraced, perhaps out of necessity, in this same time period. Not able to aid his son in any substantial manner, he encouraged Oscar to model himself after the local schoolteacher, a "self made man" who had "dug his way through." He urged, "Go ahead-you may yet be something in this unstable world." ${ }^{3}$ One has to wonder if the celebration of selfmade manhood resulted when men like Luther Fitch and Tracy Learnard realized they could not honor the New England tradition of fathers launching their sons. "Go-ahead" and "self-made man" may have been code for "I cannot do it for you."

\footnotetext{
${ }^{2}$ Edward Fitch to Luther Fitch, 28 March 1852 and 6 May 1852, Edward Fitch Papers, Newberry Library.

${ }^{3}$ Tracy Learnard to Oscar Learnard, 7 September 1853, Oscar Learnard Papers, UKRSL.
} 
Certainly by the 1850s, when a frustrated Edward Fitch fretted over the hesitance of his father to continue aiding his Western dreams, we might expect that the tide of post-Revolutionary individualism had arisen high enough to squelch expectations inherent in old patriarchal family arrangements. Unfortunately, the usual paragraph or so historians devote to this topic does not allow them to do more than gloss over the fact that change took place, and perhaps exaggerate its effects. Like all social transformations, however, this transition was uneven and took hold slowly in many instances. Those firm bands of consanguinity that formerly prevented young men from entirely choosing their own futures had also protected them from feeling the full impact of those choices. Those who planted their futures in the West harvested the consequences there.

Unfortunately, the rising culture of individualism had origins not only in Revolutionary era thinking but also in the waning of opportunity in the older and more populated seaboard states. We sometimes forget that in an age that was characterized by increased professionalism, expanding markets, nascent capitalism, and exploding technology it was still land ownership that many men, perhaps most, associated on some level with security. Samuel Thing raved about the benefits of land in the Cincinnati region in the early nineteenth century. He boasted, "I have seen corn myself so high that I could not reach the low end of the ear by a foot and a half. ... [Men] can raise twice as much with half the work, and a man can get land to suit himself in this country, and he has a good chance to pay for it." Land represented not only a potential home, expansive farm, or rentproducing estate. It was also the single most desirable commodity to those men who sought their futures in the West. Western "fever" resulted when letters like this one poured back to Eastern friends and relatives, and Thing added a sense of urgency by commenting on the flood tide of migrants: "This country is settling very 
fast. There is a great many goes through the place every day that is moving from all parts."4

In the seaboard states, overly divided estates, high land prices, or weary soils discouraged some young men contemplating independent futures. In addition, the perception that the ranks of successful men were already overcrowded there added the final nudge that pushed some men westward. Despite struggling to find a profitable mode of existence in the West, Moses Atkinson confessed to his uncle that he was "still of the opinion that I could succeed better in this country than in the East." ${ }^{5}$ Plentiful, affordable land combined with a perception that Western opportunities were as fertile as the acreage there to provide the pull necessary to finally entice many men away from Eastern homes.

Edward Fitch had to learn that choices have consequences, and they certainly do in the writing of history. However, the fact that "Go-Ahead Men" isolates men of Yankee background who migrated to the emerging West should not imply an a priori conclusion that they constituted a discrete or distinctive group. In fact, it is only through hindsight that we may even consider them as a "group," for involved in their massive migration across the Appalachians after the American Revolution were myriad individual decisions to go prompted by as many personal imaginings of what might be. Something common to this cohort was that they all wanted to advance their station and that the West was the place to do it. Who could doubt it, given the glowing reports that flowed back East from some of the earliest migrants? Samuel Thing assured his brother, "[Y]ou do not know how much better and easier you might live if you were here. ... [H]ome is a fool to this

\footnotetext{
${ }^{4}$ Samuel Thing to John Thing, 8 November 1814, Thing Family Papers, Indiana Historical Society.

${ }^{5}$ Moses Atkinson to Josiah Little, 1 November 1840, Moses Atkinson Papers, Abraham Lincoln Presidential Library.
} 
place as to getting a living." ${ }^{\prime 6}$ One thing these men believed-in fact, they counted on it-was that choices had consequences.

The three men featured in this study self-selected for inclusion in a way, although were any alive today to hear of it, none would be pleased. In truth, it was the complicated nature of their masculine relationships that drew me to read most deeply in the archives. Originally, I envisioned this project as a fairly standard whowhat-when-where narrative about ambitious Yankees seeking Western opportunities. Instead, it was the "whodunit" nature of certain stories that captivated my interest. Running beneath the life stories of John Cleves Symmes, Joshua Giddings, and Oscar Learnard was a subtext related to the ways other men earned or betrayed trust and met or failed expectations in times of crisis. Sources relating to these three men were so revealing that they invited the asking of some questions I had never seen asked before. That is how the subtitle came to be "Yankee Westerners Test Masculine Bonds in the Early American Republic."

Times of crisis or conflict reveal the weaknesses, or strengths, of relationships. They certainly did in the case of John Cleves Symmes. Symmes is unusual in that he migrated westward in his fifties after having made his mark back East. In fact, he had risen to prominence in New Jersey before the Revolution and owned a good deal of land there. So why did he move? Symmes did not want to try to recreate his leadership role in New Jersey, but he was also extremely ambitious. Dreams were not the exclusive property of the young, and his were visions of grand proportions.

Having come to age in the mid-1700s, Symmes found it hard to move from the self-perception that he was a landed gentleman patriarch, a man whose knowledge of the classics, surveying, and law were not meant to be primary 
sources of support, but ornaments suitable to a man of elevated rank. The sonless Symmes harbored similar dreams for his grandsons, John and Charles Short, and took it upon himself to sow the seeds for futures he envisioned for them also as landed gentlemen, living primarily on tenant rents. What better place than the newly opened territory north of the Ohio River to make that happen? Symmes was already there attempting to secure his own Western estate and a place in history as territorial judge and regional developer.

Symmes's connections to New England were somewhat removed. He was certainly no parochial rural Yankee, as his involvement in early national affairs and ready insertion into the heterogeneous population of the Ohio Valley region attests. His conscious attachments were to New Jersey more than anywhere else, and his wives were all from substantial mid-Atlantic families, through whom he expanded his connections. Association with the Virginia gentry came rather naturally through Symmes's acquaintances and activities.

At first, the transplanted planter's son who married Symme's elder daughter seemed the Kentucky counterpart to Symmes's vision of himself. Early on, they cooperated in their dual pursuits to become wealthy, landed gentlemen. To be sure, there were aspects of his grandsons' upbringing Symmes might wish were different, especially after Maria's death, but he contented himself with regular, instructive letters and the knowledge that he was helping to make the boys' gentlemanly futures secure.

The rapid decline of Symmes's wealth and Peyton Short's dramatic financial collapse forced Symmes to articulate more clearly the realization that economic security in the emerging West was not as easily gained as he once asserted. However, Short's flight from the reality of his condition-and his familyoffered Symmes an opportunity to act on that new awareness. He began to assert an older, patriarchal kinship model as he claimed responsibility for directing the 
boys' futures. By his actions Symmes upheld the concept of men launching male progeny into successful futures, even as he encouraged that the boys take up professions as actual income generators.

The loss of New Jersey lands the boys had inherited from their mother represented more than the squandering of potential incomes, however. Those lands, along with some Symmes bought for the boys in his own Ohio tract, represented an important way for Symmes to link to his posterity. He also intended that they function as ties to his New Jersey and New England roots, firming his own imprint on the boys' lives. Symmes had suspected Peyton Short did not support that function for the lands in question, and it finally became a wedge in their relationship. Unfortunately, it also eventually colored Symmes's relationship to John and Charles as they grew into men. Despite Symmes's outwardly cosmopolitan appearance, his New England background carried important meaning for Symmes, not so much for its general cultural implications, but because it of his ancestors' roles there.

Joshua Giddings did not have the luxury of riding influential connections all the way to Western opportunities, as did Symmes. In fact, his early boyhood was spent moving haltingly toward an eventual home in Ohio's Western Reserve. His family followed the path most typical of other early nineteenth-century New England migrants, and settled where Yankees dominated. The fact of New England origins was so common to most of Giddings's associates that they rarely felt compelled to mention it.

However, the relative homogeneity of the Reserve did not mean everyone was viewed the same way. This Giddings understood well, carrying as he did the burden of being known as the poor son of a failed man. Giddings's rise to regional prominence was aided by relatives, neighbors, and a former employer who all saw something in him worth investing in. In essence, they substituted their assistance 
for what Giddings's father could not, or would not, provide. Giddings's remarkable work ethic helped, but he also wisely linked his future success to that of Congressman Elisha Whittlesey. To financial aid and a prominent mentor he then added a cultivated ability to cooperate with Reserve men building the institutions of society in a rapidly developing environment.

So closely was Giddings identified with the men shaping that regional environment that he could not envision himself as successful without also being viewed by them as worthy of representing their collective civic voice. He weathered threats to a firm sense of self emanating from anti-Masonry and the Panic of 1837, but it was the debate over slavery that represented the greatest and most sustained challenge to masculine bonds. Historians point to the Western Reserve as an example of homogeneous transplanted New England culture and also of concentrated antislavery sentiment, even correctly noting the connection between the two. Those generalizations, while substantially true, mask an undercurrent of disrupted relationships, community discord, and constant negotiation that also existed.

Just as Giddings had functioned as Whittlsey's district political mouthpiece without questioning whether it compromised his personal civic voice, he expected Whig loyalties to bind his own young assistant to him in the same way. When some regional antislavery Whigs rejected the party and Flavel Sutliff went one step farther, moving the site of civic discourse entirely away from politics, Giddings discovered unexpected ways the slavery debate could strain close male relationships. In so doing, it also challenged him to more carefully craft the image he promoted as both guide and representative of his district's interest in Congress.

Oscar Learnard was the only one of the three men closely studied for this project who grew to adulthood in New England. He was also the one most selfconscious about owning, and promoting, Yankee culture. Remarkably, he was also 
the only one of the three who would have considered living in the slave South. Despite his chauvinism, the lure of opportunity and possibility of creating a reliable future that included his family were what drove Learnard's earliest considerations of where to settle.

Learnard was also the only one of the three for whom his closest male relationships were not a source of great disappointment. He was not a peoplepleaser, however. Those who knew him claimed he had strong opinions and expressed them openly. Two things in Learnard's favor helped him learn how to create and maintain successful masculine friendships. He spent a lot of his youth in school settings and clubs where he learned to cooperate, even in competitive settings. He also developed a strong sense of belonging and self-confidence in those academic environments, where he always excelled.

Men appeared naturally to respect Learnard, but he was sometimes uncertain whether his father was among them. In fact, he occasionally wondered exactly who it was he was working so hard to prove himself to-himself, his father, or his friends. That he cared so much about not disappointing other men's expectations of him is the reason he found the elevation of John Brown's memory so upsetting. Writers and others constructing Brown's legacy had not only perverted the real nature of the Kansas struggle; they had elevated one aberrant son of New England above those who really had, in Learnard's mind, done the important work to make Kansas free.

Similar to most Northerners of the era, Symmes, Giddings, and Learnard took for granted the opportunities that accrued only to free, white men-mobility, land ownership, and political participation. Moreover, they believed it was their right to seek fortunes or assert themselves as potential leaders. Francois Furstenberg makes a similar observation when he asserts that in the early republic, freedom "meant more than national independence, more than the right of 
self-determination, more even than the absence of physical and political coercion." According to Furstenberg, it "also lay in humans' agency: their ability to alter circumstances, to change the environment, to reform government, and above all to resist oppression." The men in this study depended upon these things being true, and often viewed obstacles placed in their way as personal affronts.

The national discussion regarding freedom and oppression was not lost on Symmes, Giddings, or Learnard. Again, similar to most Northerners, each tolerated the existence of a Southern slave society, even if he viewed it somewhat negatively, but engaged the topic more vigorously when he felt personally threatened by it. Symmes defensively asserted the superiority of free-soil regions to struggling but aspiring young men hoping to become self-respecting gentlemen, of course hoping to rescue his grandsons from following their planter father's calamitous example. Giddings found the Reserve debate over slavery threatened to disrupt his relationships on several levels. Even he, a master of cooperative male relationships, could not smooth over all the ruptures the debate produced with political or religious compatriots. Learnard, at one point willing to relocate with his parents in the South, transformed into a Kansas Free-State champion when he felt his political freedoms-and his land titles_-might be trampled by would-be slaveholders. All three men treasured the assumed privileges of free, white men in a democratic republic, embraced other men who could help them achieve their goals, and saw the topic of slavery inserted into those relationships in some degree, just as it entered the national discourse regularly in the same period.

What ambitious westering Yankees wanted most from their closest male associates was respect. The younger ones normally said they welcomed the advice of friends or male relatives, but they wanted them to acknowledge that as

\footnotetext{
${ }^{7}$ Francois Furstenberg, "Beyond Freedom and Slavery: Autonomy, Virtue, and Resistance in Early American Political Discourse," The Journal of American History (2003) 89 (4): 1295-1330.
} 
grown men, they were generally capable of finding their way, however indirectly. To be sure, the struggling younger ones also were sometimes not above letting relatives, mainly fathers, know they lacked funds, but consistently what most wanted from friends and relatives alike was acknowledgement of their abilities and judgment. Nathan Smith expressed this sentiment to his uncle, who apparently advised him to return to New England. He wrote, "Indeed I could not have expected a manifestation of more true friendship in a letter from a father. . . and although I have not proceeded according to some of your fatherly advice, I hope to convince you that I had some good reasons for not returning to New England before I close my letter." Moses Atkinson confessed to his uncle that he "may have erred in judgment" in chasing his "western fever," but the gentle message buried in this letter was that it was his decision to make when he decided to go. Ever mindful of maintaining his sense of self respect, Atkinson also noted that he might return, "[b]ut not unless I can honorably to myself." The ambitious men who migrated West wanted other men to recognize them fully as men.

Part of that expectation of respect was that close male associates would be loyal. Loyalty became especially important in times of challenged reputations or financial distress. Samuel Willard, "by venturing too far" lost everything, and confessed his distressing plight to a sympathetic relative back in Boston. Willard wrote,

I have been in apparent prosperity, surrounded by friends and enjoying the confidence of my fellow citizens. The pleasing illusion has now vanished. My sunshine friends are fled, public confidence is withdrawn, and instead of being called a man of integrity . . I am now unjustly branded with the epithets of villain and knave.'

Men who ran into misfortune expected their closest male associates to sympathize and not turn into "sunshine friends," fleeing associations that might threaten their

${ }^{8}$ Moses Atkinson to Josiah Little, 28 November 1839, Moses Atkinson Papers, Abraham Lincoln Presidential Library.

9 Samuel Willard to Julius A. Willard, 24 January 1816, Samuel Willard Family Papers, Abraham Lincoln Presidential Library. 
own fragile reputations. In other words, they hoped that bonds, once created, would remain firm.

Most of these men were hesitant to claim openly that they wanted much else from close male associates or relatives. However, this should not imply that they did not highly value the gestures that other men made on their behalf. When H. C. Beard's brother Samuel died, H. C. listed the many ways his brother's generosity had touched him:

[Samuel] had tried to do good unto others, he left his own business when poor and destitute, to minister to the wants of a sick brother; and when fortune favored him, her remembered others. . . . He said that when he got home, he would send me a thousand dollars to invest in young cattle, and we were to share alike in the profits. He liked the country so well that he was going to send me some land warrants, to enter him a large tract of land, which I was to improve, and make a beautiful farm. He left two hundred dollars with me, to hire help, to cut hay. ${ }^{10}$

There were several things these men consistently expected of themselves, as well. Across the board, they expected to apply themselves to making improvements-in their lands, in themselves, and in the communities they helped to build. The vast majority placed a high priority on maintaining family relationships, across distance if necessary. C. J. F. Clarke wrote to his friend back in New Hampshire to "[w]rite me all the town news and neighborhood scandal and the whereabouts of all my relation, uncle, aunts and cousins." ${ }^{11}$ Those who migrated as single men intended eventually to marry and create families. Although many intermingled with Native Americans, they did not intermarry with them nor promote meaningful social interaction. Actually, most found wives whose backgrounds resembled their own. As one man described it, his friend wanted "a Yankee girl for his wife, one that knows how to take care of herself." Speaking his own mind on the matter, he added, "I expect most all of the Yankee girls will get married ... . Those western

\footnotetext{
${ }^{10}$ H. C. Beard to Dear Friend, 27 July 1853, Beard Family Papers, Vermont Historical Society.

${ }^{11}$ C. J. F. Clarke to Doc Moses Hill, November, 1842, Clarke Family Papers, Abraham Lincoln Presidential Library.
} 
girls can never suit me, not never."12 These men also inserted themselves into the mainstream social and political world around them; ambitious men by definition do not tend to avoid social contact. Nearly to a man, they took an interest in the political life of the new nation.

As these men determined who they could and could not trust, they also assessed the reliability of themselves. As men who hoped to rise in the estimation of others, they frequently monitored or analyzed their own actions or thoughts, assessing whether they measured up to expectations-those of themselves and others. Consistently, they hoped they could count on their bodies to perform what their wills intended. Symmes, finding it so hard to keep reliable help, was thankful he remained so hearty well into his sixties. His life would have changed dramatically if that had not been the case. Learnard's life course took an unexpected turn away from schooling when his health faltered, leading him to an earlier examination of regions outside Vermont than he would otherwise have experienced, and a firmed commitment to additional schooling. He was able to attend college because a close friend could not, but had instead discovered easy money in California, where he had gone to remedy his own physical complaints. Giddings's own illness and foreboding of an early death eventually led him to concentrate his focus on fighting slavery with a level of commitment few could match. Faltering health was the most frequent disappointment young men encountered, and even the healthy ones consistently said they hoped their bodies did not disappoint what their ambitious natures intended them to achieve.

Finally, there was one thing that all these men expected of themselves and of close male associates, and that was that their relationships were the result of ongoing negotiation. Their close male relationships were dynamic, partly the result

\footnotetext{
12 Lucius Salisbury to Dear Harriet, 29 April 1844, Lucius Salisbury Correspondence, Vermont Historical Society. A useful recent exploration of cross-cultural relationships is Laura Ann Stoler, Haunted by Empire: Geographies of Intimacies in North America (Durham, North Carolina, 2006).
} 
of their always striving, and partly because so many men around were also working to go ahead. Often, circumstances outside the relationships themselves still had a profound impact on them. Giddings found this to be true as he witnessed the decline of first one close friendship and then others when the antislavery debate disrupted social and civil discourse across the Reserve. Symmes certainly never expected that the nature of his relationship to his grandsons would change as it did, the result of Peyton Short's dramatic fall from grace. And Learnard, who went to Kansas out of curiosity and with the thought of speculating in land, found a compelling reason to stay, a use for his previous education, and a substitute for his "beloved Green Mountain home" that felt-except for the mountains-remarkably similar. The ultimate form these men's important male relationships took was the complex result of countless considerations, negotiations, and decisions.

But still, choices have consequences. And one of the demands of formulating this study is positing that the shaping, negotiating, and testing of masculine bonds among these men was as important in its own way as the fact of their founding towns and businesses, writing laws, or guiding communities. I claim that it was. Across the board, the important male relationships of these men determined to a significant level the final direction their lives took. What scholars sometimes miss as they assess the "big picture" is that they have forgotten to ask who gave the artist his brush, or canvas, or even suggested to him that he could paint in the first place. In the developing post-Revolutionary West, the metaphoric givers of those things were other men, or more precisely, other men whose bonds of friendship or consanguinity were strong enough to help propel each other forward, but could not always bear the strain that resulted from that advance.

Although there existed a diversity of manhood models in the early republic, just as there were many kinds of men, the men in this study represent what Mark Kann calls a "mainstream culture of manhood." They were free, white, heterosexual, and fully aware that the economic and political opportunities around 
them could be theirs under the right circumstances. Despite the diversity of men's lives, Kann observes that there was still a "general consensus" that certain "norms were central to all manly ideals."

One consensual norm was that manhood required the economic and political independence sometimes known as "manly freedom." . . . An independent man was self-supporting. . . . He could afford to have his own conscience and demanded the liberty to resist any government that threatened to rob him of liberty and property, and he felt entitled to participate in public deliberations and decision making. A "man" was an independent agent of his personal and public nature. ${ }^{13}$

The diaries and letters of Yankee migrants to the emerging West concur with this general normative model of American manhood. However, a rare exception would be the man who achieved any of those things without a substantial degree of negotiation with other men important to his life-relatives, mentors, employers, or friends. Occasionally, that debate turned bitter, strainingand even breaking - the ties of fraternity. In testing those bonds, men discovered in whom and upon what they could rely.

Their impact in the developing West depended upon more than the noteworthy careers or institutions their go-aheaditive natures predicted would result. Because they did occur with such frequency, however, there sometimes exists a tendency to insert a teleological slant into the related historical narrative. There were triumphs, to be sure, but they were not inevitable. The outcomes of their lives, if those of Symmes, Giddings, and Learnard are indicators, depended as much upon the relationships men negotiated as they did the other decisions they made. Those choices also had consequences.

\footnotetext{
${ }^{13}$ Mark Kann, A Republic of Men: the American Founders, Gendered Language, and Patriarchal Politics (New York: New York University Press, 1998), 15. Francois Furstenberg concurs in the importance of free-agency to men in the early republic, and relates it to an ongoing discourse regarding slavery.
} 


\title{
BIBLIOGRAPHY
}

\section{Manuscript collections, unpublished}

\author{
Abraham Lincoln Presidential Library, Springfield, Illinois \\ Moses Atkinson Papers \\ Samuel Willard Family Papers \\ Clarke Family Papers \\ Filson Historical Society, Louisville, Kentucky \\ Short Family Papers \\ Anderson-Latham Family Papers \\ Indiana Historical Society, Indianapolis, Indiana \\ Thing Family Papers \\ William Henry Harrison Papers \\ Indiana State Library, Indianapolis, Indiana \\ George W. Julian Papers \\ Kent State University Library, Kent, Ohio \\ Betsey Mix Cowles Papers \\ Giles H. Cowles Papers \\ Kreitzberg Library, Norwich University, Northfield, Vermont \\ Oscar Learnard Papers \\ Library of Congress, Washington D.C. \\ Short-Symmes-Harrison Papers \\ Maag Library, Youngstown State University, Youngstown, Ohio \\ Joshua Giddings Papers (microfilm) \\ Newberry Library, Chicago, Illinois \\ Edward Fitch Papers \\ Spencer Research Library, University of Kansas, Lawrence, Kansas \\ Oscar Learnard Papers \\ Sutliff Museum, Warren Ohio \\ Sutliff Family Papers \\ Vermont Historical Society, Barre, Vermont
}


Beard Family Papers

Lucius Salisbury Correspondence

Western Reserve Historical Society, Cleveland, Ohio

Elisha Whittlesey Papers

Marius Robinson Papers

Vertical File Material

\section{Manuscript collections, published}

The Correspondence of John Cleves Symmes: Founder of the Miami Purchase. Edited by Beverley W. Bond, Jr. New York: MacMillan Company. 1926.

The Intimate Letters of John Cleves Symmes and His Family. Edited by Beverley W. Bond, Jr. Cincinnati: Historical and Philosophical Society of Ohio. 1956.

Letters of James Gillespie Birney, 1837-1857 Vol. 1. Edited by Dwight L. Dumond. Gloucester, Massachusetts: Peter Smith. 1966.

Letters of Theodore Dwight Weld, Angelina Grimke Weld, and Sarah Grimke, 1822-1844 Vol. 2. Edited by Gilbert Barnes and Dwight L. Dumond. Gloucester, Massachusetts: Peter Smith, 1965.

Letters of Mrs. Ann Biddle Wilkiinson from Kentucky, 1788-1789. Ann Biddle Wilkinson and Thomas Robson Hay. Kessinger. 2006.

Papers of Henry Clay Vol. 6. Edited by Mary W. M. Hargreaves and James F. Hopkins. Lexington: University Press of Kentucky. 1981.

\section{Newpapers and news journals (clippings/scrapbooks not included)}

African Repository and Colonial Journal, Vols. 9-16. 1833-1840

Ashtabula (Ohio) Sentinel. 1834-1838

Liberator. 1833-1837

Ohio Luminary. 1830

Ohio Observer. 1835-1837

University Regulator. Norwich University, Kreitzberg Library (Oscar Learnard Papers). Northfield, Vermont. 1854-1855.

Western Reserve Chronicle. 1837 


\section{Miscellaneous publications (proceedings, laws, magazines, and catalogs)}

Acts of a General Nature Passed by the Forty-Seventh General Assembly of the State of Ohio Vol. XLVII. Columbus. 1849

American Magazine of Useful and Entertaining Knowledge. Vol.1. Boston: Sibley and Ticknor. 1836.

American Magazine of Useful and Entertaining Knowledge. Vol. 3. Boston: Sibley and Ticknor. 1837.

Ballou's Monthly Magazine, Vol. 13. Boston: 1861

Catalog of the Corporation, Officers, and Cadets of Norwich University. Montpelier, Vermont. Publications for 1851-2 and also 1853.

Catalogue of the Officers and Students of Bakersfield Academical Institution. Windsor. 1851.

Fourth Annual Report of the American Anti-Slavery Society. New York. 1837.

Knowledge: An Illustrated Magazine of Science, Literature and Art, Vol. 10. Edited by Richard Proctor. Richard Proctor. 1886.

Third Annual Report of the American Antislavery Society. New York: William S. Dorr. 1836.

Western Reserve and Northern Ohio Historical Society Ninth Annual Meeting, May, 1877. Cleveland: Western Reserve Historical Society. 1877.

\section{Books and Articles}

Abzug, Robert H. Cosmos Crumbling: American Reform and the Religious Imagination. New York: Oxford University Press. 1994.

------. Passionate Liberator: Theodore Dwight Weld and the Dilemma of Reform. New York: Oxford University Press. 1980.

Ambrose, Stephen E. Duty, Honor, Country: A History of West Point. Baltimore: Johns Hopkins University Press. 1999.

The American College in the Nineteenth Century. Edited by Roger L. Geiger. Nashville: Vanderbilt University Press. 2000 
Americanisms, Old and New. Edited by John. S. Farmer. London: Poulter and Sons. 1889.

Appleby, Joyce. Inheriting the Revolution: The First Generation of Americans. Cambridge, Massachusetts: Belknap Press. 2000.

Appleton, Elizabeth Haven. In Memory of Elizabeth Haven Appleton is Printed this Selection of Her Lectures. Cincinnati: Robert Clarke and Company. 1891.

Augst, Thomas. The Clerk's Tale: Young Men and Moral Life in NineteenthCentury America. Chicago: University of Chicago Press. 2003.

Bartlett, Irving $\mathrm{H}$. The American Mind in the Mid-Nineteenth Century, $2^{\text {nd }}$ ed. Wheeling, Illinois: Harlan Davidson, Inc. 1982.

Barron, Hal S. Those Who Stayed Behind: Rural Society in Nineteenth-Century New England. Cambridge: Cambridge University Press. 1984.

Bender, Thomas. Community and Social Change in America. New Brunswick, New Jersey: Rutgers University Press. 1978.

Billingsley, Carolyn Earle. Communities of Kinship: Antebellum Families and the Settlement of the Cotton Frontier. Athens, Georgia: University of Georgia Press. 2004.

Blauvelt, Martha Tomhave. The Work of the Heart: Young Women and Emotion, 1780-1830. Charlottesville: University of Virginia Press. 2007.

Blumin, Stuart M. The Emergence of the Middle Class: Social Experience in the American City, 1760-1900. Cambridge: University of Cambridge Press. 1989.

------. "The Hypothesis of Middle-Class Formation in Nineteenth-Century America: A Critique of Some Proposals." American Historical Review 90 (April 1995): 299-338.

Bond, Beverley W., Jr. The Civilization of the Old Northwest: A Study of Political, Social, and Economic Development, 1788-1812. New York: MacMillan Company. 1934.

Brooks, Van Wyck. The Flowering of New England, 1815-1865, Rev. Ed. E. P. Dutton and Company. 1940

Bradburn, Douglas. The Citizenship Revolution: Politics and the Creation of the American Union, 1774-1804. Charlottesville: University of Virginia Press. 2009. 
Brady, Patricia. A Being So Gentle: the Frontier Love Story of Rachel and Andrew Jackson. New York: Palgrave. 2011.

Buell, Walter. Joshua R. Giddings: A Sketch. Cleveland: William W. Williams. 1882.

Buley, R. Carlyle. The Old Northwest: Pioneer Period, 1815-1840. Bloomington: Indiana University Press. 1950.

Calhoun, Daniel H. Professional Lives in America: Structure and Aspiration, 17501850. Cambridge: Harvard University Press. 1965.

Carnes, Mark C. "Middle-Class Men and the Solace of Fraternal Ritual." In Meanings for Manhood: Constructions of Masculinity in Victorian America. Edited by Mark C. Carnes and Clyde Griffen. Chicago: University of Chicago Press. 1990.

Cashin, Joan. A Family Venture: Men and Women on the Southern Frontier. Baltimore: Johns Hopkins University Press. 1994.

Castiglione, Baldesar. The Book of the Courtier. Translated by George Bull. Middlesex, England: Penguin Books. 1980.

Cawelti, John G. The Apostles of the Self-Made Man. Chicago: University of Chicago Press.1965.

Cayton, Andrew R. L. The Frontier Republic: Ideology and Politics in the Ohio Country, 1780-1825. Kent, Ohio: Kent State University Press. 1986.

--.-. "Land, Power, and Reputation: The Cultural Dimension of Politics in the Ohio Country." William and Mary Quarterly, $3^{\text {rd }}$ ser., Vol. 47, No. 2 (April 1990): 266-286.

Cayton, Andrew R. L. and Peter S. Onuf. The Midwest and the Nation: Rethinking the History of an American Region. Bloomington: Indiana University Press. 1990.

Chambers, Thomas A. Drinking the Waters: Creating an American Leisure Class at Nineteenth-Century Mineral Springs. Washington: Smithsonian Institution. 2002.

Church, Charles A. History of Rockford and Winnebago County Illinois from the First Settlement in 1834 to the Civil War. Rockford, Illinois: New England Society of Rockford, Illinois. 1900. 
Clark, Christopher M. Social Change in America. Chicago: Ivan R. Dees. 2006.

Clawson, Mary Ann. Constructing Brotherhood: Class, Gender, and Fraternalism. Princeton: Princeton University Press. 1989.

Clinton, Catherine and Christine Lunardini. The Columbia Guide to Women in the Nineteenth Century. New York: Columbia University Press. 2000.

Coffey County Vol. 1. Edited by Wanda Christy. Coffey County. June 1987.

Coffey County Vol. 1. Coffey County, Kansas: Coffey County Today. 1987.

Cole, Donald B. Vindicating Andrew Jackson: The 1828 Election and the Rise of the Two-Party System. Lawrence, Kansas: University of Kansas Press. 1999.

Condensed History of Jefferson, Ashtabula County, Ohio. Jefferson: J. A. Howells and Co. 1878.

Connelley, William E. A Standard History of Kansas and Kansans. Vol. 5. Chicago: Lewis Publishing Company. 1918.

Connelley, William E. and Ellis M. Coulter. History of Kentucky, in five volumes. American Historical Society. 1922.

Cutler, Carroll. A History of Western Reserve College: during is first half-century 1826-1876. Cleveland: Crocker's Publishing House. 1876.

Corbett, Theodore. The Making of American Resorts: Saratoga Springs, Ballston Spa, and Lake George. New Brunswick, New Jersey: Rutgers University Press. 2001.

Davison, Kenneth Edwin. "Forgotten Ohioan: Elisha Whittlesey, 1783-1863." Ph.D. dissertation. Western Reserve University. 1953.

DeBlasio, Donna Marie. "Her Own Society: The Life and Times of Betsey Mix Cowles, 1810-1876." Ph.D. dissertation. Kent State University. 1980.

D'Emilio, John and Estelle B. Freedman. Intimate Matters: A History of Sexuality in America, $2^{\text {nd }} \mathrm{Ed}$. Chicago: University of Chicago Press. 1998.

Ditz, Toby L. "Shipwrecked: or, Masculinity Imperiled: Mercantile Representations of Failure and the Gendered Self in Eighteenth-Century Philadelphia." The Journal of American History, Vol. 81, No. 1 (June 1994): 51-80. 
Donnelley, William Elsey and Ellis Merton Coulter. History of Kentucky, in five volumes. American Historical Society. 1922.

Cordley, Richard. Lawrence, Kansas: The First Settlement to the Close of the Rebellion. Lawrence, Kansas: E. F. Caldwell. 1895.

Elllis, William Arba. Norwich University: Her history, her graduates, her roll of honor. Concord, New Hampshire: William Ellis. 1898.

Eslinger, Ellen. "The Evolution of Racial Politics in Early Ohio." In The Center of a Great Empire: The Ohio Country in the Early Republic. Edited by Andrew R. L. Cayton and Stuart D. Hobbs. Athens, Ohio: Ohio University Press. 2005.

Etcheson, Nicole. Bleeding Kansas: Contested Liberty in the Civil War Era. Lawrence, Kansas: University Press. of Kansas. 2004.

-----. "Manliness and the Political Culture of the Old Northwest, 1790-1860." Journal of the Early Republic 15 (Spring 1995): 59-77.

Faris, John T. The Romance of Forgotten Men. Freeport, New York: Books for Libraries Press. 1969.

Feller, Daniel. The Jacksonian Promise: America, 1815-1840. Baltimore: Johns Hopkins University Press. 1995.

-----. Daniel. “Oh Why, Oh Why Ohio?” Reviews in American History 17 (1989): 205-209.

Finkelman, Paul. An Imperfect Union: Slavery, Federalism, and Comity. Union, New Jersey: Lawbook Exchange, Ltd. 2000.

Finney, Charles G. Charles G. Finney: an Autobiography. Westwood, New Jersey: Fleming H. Revell. 1908.

Fischer, David Hackett and James C. Kelley. Bound Away: Virginia and the Westward Movement. Charlottesville, Virginia: University of Virginia Press. 2000.

Fleming, Thomas. The Intimate Lives of the Founding Fathers. New York: Harper Collins. 2009.

Freeman, Joanne B. Affairs of Honor: National Politics in the New Republic. New Haven: Yale University Press. 2001. 
Foote, Abram W. Comprising the Geneaology and History of Nathaniel Foote of Weathersfield, Conn., and his Descendants Vol. 1. Rutland, Vermont: Marble City Press-The Tuttlle Company. 1907.

Foster, Thomas A. Sex and the Eighteenth-Century Man: Massachusetts and the History of Sexuality in America. Boston: Beacon Press. 2006.

Frank, Stephen M. Life With Father: Parenthood and Masculinity in the Nineteenth Century. Baltimore: Johns Hopkins University Press. 1998.

Friend, Craig Thompson. "Belles, Benefactors, and Blacksmith's Son: Cyrus Stuart and the Enigma of Southern Gentlemanliness." In Southern Manhood: Perspectives on Masculinity in the Old South. Edited by Craig Thompson Friend and Lorri Glover. Athens, Georgia: University of Georgia Press. 2004.

Furstenberg, Francois. "Beyond Freedom and Slavery: Autonomy, Virtue, and Resistance in Early American Political Discourse." The Journal of American History (2-3) 89 (4): 1295-1330.

Galbreath, C. B. "Anti-slavery Movement in Columbiana County." Ohio Archaeological and Historical Quarterly 30 (October 1921): 355-395.

Garrison, William Lloyd. Thoughts on African Colonization, or an Impartial Exhibition of Doctrines, Principles and Purposes of the American Colonization Society, together with the Resolutions, Addresses and Remonstrances of Free People of Color. Boston: Garrison and Knapp. 1832.

Geiger, Roger with Julie Ann Bubolz. "College as it was in the Mid-Nineteenth Century." In The American College in the Nineteenth Century. Edited by Roger L. Geiger. Nashville: Vanderbilt University Press. 2000.

Gibbs, Phillip Andrew. "Seasons of American Manhood, 1750-1860: Mirror of the Changing Republic." Ph.D dissertation. Mississippi State University. 1988.

Giddings, Joshua R. Pacificus, the Rights and Privileges of the Several States in Regard to Slavery. 1842. Cornell University Library Digital Reprint Collections.

Gilmore, David D. Manhood in the Making: Cultural Concepts of Masculinity. New Haven: Yale University Press. 1990.

Glover, Lorri. “'Let Us Manufacture Men': Educating Elite Boys in the Early National South." In Southern Manhood: Perspectives on Masculinity in the Old South. Edited by Craig Thompson Friend and Lorri Glover. Athens, Georgia: University of Georgia Press. 2004. 
-----. Southern Sons: Becoming Men in the New Nation. Baltimore: Johns Hopkins University Press. 2007.

Goodman, Paul. Towards a Christian Republic: Antimasonry and the Great Transition in New England, 1826-1836. New York: Oxford University Press. 1988.

Graham, Sylvester B. A Defense of the Graham System of Living, or Remarks on Diet and Regimen Dedicated to the Rising Generation. New York: Applegate. 1835.

Gray, Susan E. The Yankee West: Community Life on the Michigan Frontier. Chapel Hill: University of North Carolina Press. 1996.

Green, Thomas Marshall. The Spanish Conspiracy: a review of the early Spanish movements in the South-West. Ithaca: Cornell University Library. 2009.

Greenberg, Kenneth S. Honor and Slavery: Lies, Duels, Noses, Masks, Dressing as a Woman, Gifts, Strangers, Humanitarianism, Death, Slave Rebellions, the Proslavery Argument, Baseball, Hunting, Gambling in the Old South. Princeton: Princeton University Press. 1996.

Griffin, Patrick. American Leviathan: Empire, Nation, and Revolutionary Frontier. New York: Hill and Wang. 2007.

Griffeths, D., Jr. Two Years in the New Settlements of Ohio. Ann Arbor, Michigan: University Microfilms, Inc. 1966.

Grossberg, Michael. "Institutionalizing Masculinity: The Law as a Masculine Profession." In Meanings for Manhood: Constructions of Masculinity in Victorian America. Edited by Mark C. Carnes and Clyde Griffen. Chicago: University of Chicago Press. 1990.

Gruenwald, Kim M. River of Enterprise: The Commercial Origins of Regional Identity in the Ohio Valley, 1790-1850. Bloomington: Indiana University Press. 2002.

Haines, Michael R. "The White Population of the United States, 1790-1820." In A Population History of North America, edited by Michael R. Haines and Richard Hall Steckel. Cambridge: Cambridge University Press. 2000.

Halttunen, Karen. Confidence Men and Painted Women. New Haven: Yale University Press. 1982. 
Hambrick-Stowe, Charles E. Charles G. Finney and the Spirit of Modern Evangelism. Grand Rapids, Michigan: W. B. Eerdmans. 1996

Harrison, Lowell H. and James C. Klotter. A New History of Kentucky. Lexington: University of Kentucky Press. 1997.

Hatcher, Harlan. The Western Reserve: The Story of New Connecticut in Ohio. Kent, Ohio: Kent State University Press. 1991.

Hemphill, C. Dallett. Bowing to Necessities: A History of Manners in America, 1620-1860. New York: Oxford University Press. 1999.

Hermann, Richard Muelder. Fighters for Freedom: A History of Anti-slavery Activities of Men and Women Associated with Knox College. New York: Columbia University Press. 2005.

Hessinger, Rodney. Seduced, Abandoned, and Reborn: Visions of Youth in Middle-Class America, 1780-1850. Philadelphia: University of Pennsylvania Press. 2005.

Hirrel, Leo P. Children of Wrath: New School Calvinism and Antebellum Reform. Lexington: University Press of Kentucky. 1998.

His Soul Goes Marching On: Responses to John Brown and the Harper's Ferry Raid. Edited by Paul Finkelman. Charlottesville: University of Virginia Press. 1995.

Historical Collections of the Mahoning Valley. Youngstown, Ohio: Mahoning Valley Historical Society. 1876.

History of Trumbull and Mahoning County Vol. 2. Edited by H. Z. Williams and Bro. Cleveland: H. Z. Williams and Bro. 1882.

Holbrook, Stewart H. The Yankee Exodus: An Account of Migration from New England. (New York: MacMillan. 1950.

Hollon, W. Eugene. Frontier Violence: Another Look. New York: Oxford University Press. 1974.

Holman, Hamilton. "An Indiana College Boy in 1836: The Diary of Richard Henry Holman." Indiana Magazine of History 49 (September 1953): 281-306.

Holt, Micahel F. The Political Crisis of the 1850s. New York: W. W. Norton and Company. 1978. 
Howard, Victor B. Conscience and Slavery: The Evangelistic Calvinist Domestic Missions, 1837-1861. Kent, Ohio: Kent State University Press. 1990.

Howe, Daniel Walker. Making of the American Self: Jonathan Edwards to Abraham Lincoln. Oxford: Oxford University Press. 2009.

Howe, Daniel Walker. What Hath God Wrought: The Transformation of America, 1815-1848. New York: Oxford University Press. 2007.

Howe, Henry. Historical Collections of Ohio in Two Volumes, Vol. 1. Cincinnati: State of Ohio. 1900.

Howells, W. D. Years of My Youth. New York: Harper and Brothers. 1916.

Hurt, R. Douglas. "John Cleves Symmes and the Miami Purchase." In Builders of Ohio, edited by Warren Van Tine and Michael Pierce. Columbus, Ohio: Ohio State University Press. 2003.

-----. The Ohio Frontier: Crucible of the Old Northwest, 1720-1830. Bloomington, Indiana. 1996.

Johnson, Samuel A. "The Emigrant Aid Company in the Kansas Conflict." Kansas Historical Quarterly 6:1 (February 1937): 21-33.

James, Marquis. The Life of Andrew Jackson. New York: Garden City Publishing. 1940.

Jeffrey, Julie Roy. The Great Silent Army of Abolitionism: Ordinary Women in the Antislavery Movement. Chapel Hill: University of North Carolina Press. 1998.

Jenks, William L. "Territorial Legislation by Governor and Judges." The Mississippi Valley Historical Review 5, no. 1 (1918): 36-50.

Johnson, Paul. A Shopkeeper's Millennium: Society and Revivals in Rochester, New York, 1815-1837. New York: Hill and Wang. 2004.

Julian, George Washington. The Life of Joshua R. Giddings. Chicago: A. C. McClurg and Company. 1892.

Kann, Mark. A Republic of Men: the American Founders, Gendered Language, and Patriarchal Politics. New York: New York University Press. 1998.

Kasson, John F. Rudeness and Civility: Manners in Nineteenth-Century Urban America. New York: Hill and Wang. 1990. 
Kennedy, William S. The Plan of Union or a History of the Presbyterian and Congregational Churches of the Western Reserve. Hudson, Ohio: Pentagon Steam Press. 1856.

Kierner, Cynthia A. "Martha Jefferson and the American Revolution in Virginia." In Children and Youth in a New Nation. Edited by James Marten. New York: New York University Press. 2009.

Kimmel, Michael. Manhood in America: A Cultural History. New York: Free Press. 1996.

Knepper, George W. Ohio and its People. Kent, Ohio: Kent State University Press. 1989.

Laslett, Peter. Illicit Love in Earlier Generations: Essays in Historical Sociology. Cambridge: Cambridge University Press. 1980.

The Laws of the Territory of Kansas passed January 12, 1857. Lecompton: Kansas Territory. 1857.

Lewis, Charlene M. Boyer. Ladies and Gentlemen on Display: Planter Society at the Virginia Springs, 1790-1860. Charlottesville: University Press of Virginia. 2001.

Lewis, Jan. "The Blessings of Domestic Society." In Jeffersonian Legacies, edited by Peter S. Onuf. Charlottesville: University Press of Virginia. 1993.

Linklater, Andro. The Artist in Treason: the Extraordinary Double Life of General James Wilkinson, Commander in Chief of the United States Army and Agent 13 in the Spanish Secret Service. New York: Walker. 2009.

Lombard, Anne. Making Manhood: Growing Up Male in Colonial New England. Cambridge: Harvard University Press. 2003.

Luskey, Brian P. "Jumping Counters in White Collars: Manliness, Respectability, and Work in the Antebellum City." Journal of the Early Republic 26 (Summer 2006): 173-219.

------. On the Make: Clerks and the Quest for Capital in Nineteenth-Century America. New York: New York University Press. 2010.

Manliness and Morality: Middle-Class Masculinity in Britain and America 18001940. Edited by J. A. Mangan and James Walvin. Manchester, England: Manchester University Press. 1987. 
Matajasic, Thomas D. "Whig Support for African Colonization: Ohio as a Test Case." Mid-America: 66: 2 (1981): 79-91.

McCormick, Virginia and Robert McCormick. New Englanders on the Ohio Frontier: Migration and Settlement of Worthington, Ohio. Kent, Ohio: Kent State University Press. 1998.

McCurdy, John Gilbert. Citizen Bachelors: Manhood and the Creation of the United States. Ithaca, New York: Cornell University Press. 2009.

McFarland, Gerald. A Scattered People: An American Family Moves West. New York: Penguin Books. 1987.

McGrane, Reginald Charles. The Panic of 1837: Some Financial Problems of the Jacksonian Era. Chicago: University of Chicago Press. 1965.

Memorial of the Pioneer Women of the Western Reserve Vol. 1. Edited by Gertrude Van Rensselaer Wickham. Cleveland: Cleveland Centennial Commission. 1896.

Merrill, Boynton, Jr. Jefferson's Nephews: A Frontier Tragedy. Lincoln, Nebraska: University of Nebraska Press. 2004.

Meyers, Marvin. The Jacksonian Promise: America 1815-1840. Baltimore: Johns Hopkins University Press. 1995.

Middleton, Stephen. The Black Laws: Race and the Legal Process in Early Ohio. Athens, Ohio: Ohio University Press. 2005.

Milligan, Fred J. Ohio’s Founding Fathers. Lincoln, Nebraska: iUniverse. 2003.

Nelson, Dana D. National Manhood: Capitalist Citizenship and the Imagined Fraternity of White Men. Durham, North Carolina: Duke University Press. 1998.

Nissenbaum, Stephen. Sex, Diet, and Debility in Jacksonian America: Sylvester Graham and Health Reform. Chicago: Dorsey Press. 1998.

Nye, Russell B. "Marius Robinson, a Forgotten Abolitionist Leader." Ohio Archaeological and Historical Quarterly 55 (April-June 1946): 139-154.

Oates, Stephen. To Purge This Land With Blood: A Biography of John Brown, $2^{\text {nd }}$ ed. Amherst, Massachusetts: University of Massachusetts Press. 1984.

The Oberlin Jubilee, 1833-1883. Edited by W. G. Ballantine. Oberlin, Ohio: E. J. Goodrich. 1883. 
Oertel, Kristen Tegtmeier. "'The Free Sons of the North' versus "The Myrmidons of Boder Ruffianism': What Makes a Man in Bleeding Kansas?" Kansas History: A Journal of the Central Plains 25 (Autumn 2002).

Opal, Jason M. Beyond the Farm: National Ambitions in Rural New England. Philadelphia: University of Pennsylvania Press. 2008.

Owens, Robert M. Mr. Jefferson's Hammer: William Henry Harrison and American Indian Policy. Norman, Oklahoma: Oklahoma University Press. 2007.

Park, Roberta J. "Biological Thought, Athletics and the Formation of a 'Man of Character, 1830-1940." In Manliness and Morality: middle-class masculinity in Britain and America 1800-1940. Edited by J. A. Mangan and James Walvin. Manchester, England: Manchester University Press. 1987.

Parker, L. Newton. History and Genealogy of the Ancestors and Descendants of Captain Israel Jones of Barkhamsted, Connecticut. Prepared for Hon. Asahel Wellington Jones. 1902.

Parsons, Lynn Hudson. The Birth of Modern Politics: Andrew Jackson, John Quincy Adams, and the Election of 1828. New York: Oxford University Press. 2009.

Pessen, Edward. Jacksonian America: Society, Personality, and Politics. Urbana: University of Illinois Press. 1985.

-----. Riches, Class, and Power: America Before the Civil War. New Brunswick: Transaction. 1990.

Peterson, Merrill. John Brown: The Legend Revisited. Charlottesville: University of Virginia Press. 2002.

Pioneer and General History of Geauga County, with sketches of some of the Pioneers and Prominent Men. Burton, Ohio: Historical Society of Geauga County. 1880.

Power, Richard Lyle. Planting Corn Belt Culture: The Impress of the Upland Southerner and Yankee is the Old Northwest. Indianapolis: Indiana Historical Society. 1953.

Price, Robert. "Further Notes on Granville's Anti-abolition Disturbances of 1836." Ohio History 45 (October 1936): 365-368. 
------. "The Ohio Anti-slavery Convention of 1836." Ohio History 45:2 (April 1936).

The Pursuit of Public Power: Political Culture in Ohio, 1787-1861. Edited by Jeffrey P. Brown and Andrew R. L. Cayton. Kent, Ohio: Kent State University Press. 1994.

Ratcliffe, Donald J. "The Market Revolution and Party Alignments in Ohio." In The Pursuit of Public Power: Political Culture in Ohio, 1787-1861, edited by Jeffrey P. Brown and Andrew R. L. Cayton. Kent, Ohio: Kent State University Press. 1994.

-------. Party Spirit in a Frontier Republic: Democratic Politics in Ohio, 1793-1821. Columbus: Ohio University Press. 1998.

Remini, Robert V. Andrew Jackson. New York: Harper Perennial. 1966.

Reznick, Samuel. "The Social History of an American Depression, 1837-1843." American History Review 40 (October 1934-July 1935): 662-687.

Reynolds, David S. John Brown, Abolitionist: The Man Who Killed Slavery, Sparked the Civil War, and Seeded Civil Rights. New York: Vintage Books. 2006.

Richards, Leonard L. "Gentlemen of Property and Standing": Anti-Abolition Mobs in Jacksonian America. New York: Oxford University Press. 1971.

Riddle, A. G. Bart Ridgeley: A Story of Northern Ohio. T. Nagar, Chennai, India: Tutis Publishing. 2007.

-------. The Life of Benjamin F. Wade. Cleveland: Williams. 1888.

Robertson, Stacey. Hearts Beating for Liberty: Women Abolitionists in the Old Northwest. Chapel Hill: University of North Carolina Press. 2010.

Rohrbaugh, Malcomb J. The Transappalachian Frontier: People, Societies, and Institutions 1775-1850. New York: Oxford University Press. 1978.

Rose, Anne C. Victorian America and the Civil War. New York: Cambridge University Press. 1992.

Rotundo, Anthony. American Manhood: Transformations in Masculinity from the Revolution to the Modern Era. New York: Basic Books. 1993.

Rudolph, Frederick. The American College and University: A History, Rev. Ed. Athens,Georgia: University of Georgia Press. 1990. 
-----. "The Rise and Fall of Useful Knowledge: Higher Education for Science, Agriculture, and the Mechanic Arts, 1850-1875." In The American College in the Nineteenth Century. Edited by Roger L. Geiger. Nashville: Vanderbilt University Press. 2000.

Ryan, May P. Cradle of the Middle Class: the Family in Oneida County, New York, 1790-1865. Cambridge: University of Cambridge Press. 1981.

Salmon, Marylynn. Women and the Law of Property in Early America. Chapel Hill: University of North Carolina Press. 1986.

Sandage, Scott A. Born Losers: A History of Failure in America. Cambridge, Massachusetts: Harvard University Press. 2005.

Saslaw, Rita. "Student Societies in Nineteenth Century Ohio: Misconceptions and Realities." Ohio History 88 (Spring 1979): 198-210.

Sellers, Charles. The Market Revolution in America: Jacksonian America, 18151846. Chicago: Ivan R. Dee. 2006.

Shackelford, George Green. Jefferson's Adoptive Son: The Life of William Short, 1759-1848. Lexington, Kentucky: University Press of Kentucky, 1993.

Shannon, Timothy J. "This Unpleasant Business: The Transformation of Land Speculation in the Ohio Country, 1787-1820." In The Pursuit of Public Power: Political Culture in Ohio, 1787-1861, edited by Jeffrey P. Brown and Andrew R. L. Cayton. Kent, Ohio: Kent State University Press. 1994.

Sheldon, N. L. "Norwich University." New England Magazine. 1899.

Silbey, Joel. Martin Van Buren and the Emergence of American Popular Politics. Lahman, Maryland: Rowman and Littlefield. 2002.

Smith, Daniel Scott. "The Long Cycle in American Illegitimacy and Prenuptial Pregnancy." In Bastardy and its Comparative History: Studies in the History of Illegitimacy and Marital Non-conformism. Edited by Peter Laslett. Cambridge, Massachusetts: Harvard University Press. 1980.

Speed, Thomas. The Political Club, Danville, Kentucky, 1786-1790. Louisville: Filson Club Publications. 1894.

Stauffer, John. The Black Hearts of Men: Radical Abolitionists and the Transformation of Race. Cambridge, Massachusetts: Harvard University Press. 2002. 
Stewart, James Brewer. Joshua R. Giddings and the Tactics of Radical Politics. Cleveland: Case Western Reserve University. 1970.

Stoler, Laura Ann. Haunted by Empire: Geographies of Intimacies in North America. Durham, North Carolina. 2006.

Stone, Lawrence. Road to Divorce: England, 1537-1987. Oxford: Oxford University Press. 1990.

Taylor, William R. Cavalier and Yankee: The Old South and the American National Character. Garden City, New York: Anchor Books. 1963.

Temin, Peter. The Jacksonian Economy. New York: W. W. Norton and Company. 1969.

Terrible Swift Sword: The Legacy of John Brown. Edited by Peggy Russo and Paul Finkelman. Athens, Ohio: Ohio University Press. 2005.

Toplovich, Ann. "Marriage, Mayhem, and Presidential Politics: The RobardsJackson Backcountry Scandal." Ohio Valley History (Winter, 2005): 3-22.

Trefousse, Hans L. Benjamin Franklin Wade, Radical Republican from Ohio. New York: Twayne. 1963.

Upton, Harriet Taylor. History of the Western Reserve Vol. 1. Chicago: Lewis Publishing. 1910.

Volpe, Vernon L. "Benjamin Wade's Strange Defeat." Ohio History 95 (SummerAutumn 1987): 122-132.

------. Forlorn Hope of Freedom: The Liberty Party in the Old Northwest, 18381848. Kent, Ohio: Kent State University Press. 1990.

------. "The Ohio Election of 1838: A Study in the Historical Method?" Ohio History 95 (Summer-Autumn 1987): 122-132.

Wade, Richard C. The Urban Frontier: Pioneer Life in Early Pittsburgh, Cincinnati, Lexington, Louisville, and St. Louis. Chicago: University of Chicago Press. 1959.

Wallach, Glenn. Obedient Sons: The Discourse of Youth and Generations in American Culture, 1630-1860. Amherst, Massachusetts: University of Massachusetts Press. 1997. 
Watson, David K. "The Early Judiciary, Early Laws and Bar of Ohio." Ohio History 3 (1897), 141-160.

Weber, Max. The Protestant Ethic and the Spirit of Capitalism. New York: Scribner and Sons. 1958.

Whitman, Walt. I Sit and Look Out: Editorials from the Brooklyn Daily Times, by Walt Whitman. Edited by Emory Holloway and Vernolian Schwartz. New York. 1932.

Williams, Burton. "Erastus D. Ladd's Description of the Lawrence Massacre." Kansas Historical Quarterly 29:2 (Summer 1963): 113-121.

Williams, William O. History of Ashtabula County, Ohio. Philadelphia: William O. Williams. 1878.

Wilson, Lisa. Ye Heart of a Man: The Domestic Life of Men in Colonial New England. New Haven: Yale University Press. 1999.

Wood, Gordon S. The Creation of the American Republic 1776-1787. Chapel Hill: University of North Carolina Press. 1969.

Empire of Liberty: A History of the Early Republic, 1789-1815. New York: Oxford University Press. 2009.

-------. The Radicalism of the American Revolution. New York: Vintage Books. 1991.

Wyatt-Brown, Bertram. Southern Honor: Ethics and Behavior in the Old South. Oxford: Oxford University Press. 1982.

Yanni, Carla. The Architecture of Madness: Insane Asylums in the United States. Minneapolis: University of Minnesota Press. 2007.

Young, Nancy Beck. "Anna Tuthill Symmes Harrison." In Presidential Wives, an Anecdotal History. Edited by Paul F. Boller. New York: Oxford University Press. 1998. 


\title{
CHARLOTTE (CATHY) RODABAUGH
}

\author{
242 Bradford Drive, Canfield, OH 44406
}

330-533-3964 (home), 330-233-2743 (cell); catrodabaugh@gmail.com

\section{Education}

Ph.D. History, West Virginia University

Fields: $19^{\text {th }}$-Century US, Colonial US, World History

Dissertation: "Go-Ahead Men: Yankee Westerners Test Masculine Bonds in the Early American Republic"

M.A. (2004) and B.A. (2001), History, Youngstown State University

Professional Writing/Editing minor

\section{Professional Experience}

Graduate instructor, WVU Department of History (2004-2008). Courses: US I, US II, World II

Researcher, copyeditor, Walking/Driving Tour Book of Youngstown, Ohio (YSU Center for Historic Preservation)

Researcher, Erie Canal Western Gateway Project (YSU Center for Historic Preservation)

Contributor, The Business Journal, Youngstown, $\mathrm{OH}$

Editorial assistant, History of the Irish in the Mahoning Valley, Irish-American Archival Society/Arcadia Press

Editorial assistant, Antislavery Papers of the Western Reserve project, phase one

ETS national AP US history exam reader 


\section{Publications}

"The Emancipation of a Political Abolitionist: Joshua Giddings and the Struggle for Manhood." Under revision for The Journal of the Early Republic.

Review of lan Michael Spurgeon, Man of Douglas, Man of Lincoln: the Political Odyssey of James Henry Lane (University of Missouri Press, 2008), for Journal of the Early Republic (Summer 2010).

Review of Fred W. Sauceman, The Place Setting: Timeless Tastes of the Mountain South, from Bright Hope to Frog Level (Mercer University Press, 2006), for West Virginia History, (forthcoming).

Review of Peggy A. Russo and Paul Finkelman, eds., Terrible Swift Sword: The Legacy of John Brown (Ohio University Press, 2005), for West Virginia History (Fall 2008).

Review of Patrick Griffin, American Leviathan: Empire, Nation, and Revolutionary Frontier (Hill and Wang, 2009), for West Virginia History (Fall 2009).

The World of Frederick Douglas, 1818-1895 (Oxford Press, 2006), two entries.

The Encyclopedia of Slavery and Emancipation (Greenwood Press, 2006), two entries

\section{Presentations}

"The Body Proper and the Body Politic: the Giddings-Sutliff Relationship as a Case Study": Society for Historians of the Early American Republic (SHEAR) (July 2011)

"Joshua Giddings and the Emancipation of a Political Abolitionist": Illinois Historical Society Annual Symposium (2010) and SHEAR (2009) and Rush D. Holt History Conference (2009) and Ohio Academy of History (2004)

"'A Man's Work in a Man's Way': Oscar Learnard and the Transmission of Masculine Culture to Bleeding Kansas": SHEAR (2008)

"Making Great as Well as Good Men: John Cleves Symmes and His Grandsons": Ohio Valley History Conference (Western Kentucky University, 2005) and Rush D. Holt History Conference (WVU, 2007) 
"Ambitious Brotherhood: Yankee Masculinity and the American Frontier": Eberly College Research Festival (2007) and WVU Inaugural Week (2007, by invitation)

Antislavery Papers of the Western Reserve project, phase one: Quest (2004)

"Anti-German Responses in Youngstown in 1918": Ohio Academy of History (2002)

"The Early Burial Culture of Canfield, Ohio": Quest (2001)

\section{Awards, Honors}

Outstanding Doctoral Student award, Department of History, WVU

Gilder Lehrman Institute of American History Research Fellowship

Filson Historical Society Research Fellowship

Colonial Dames of America Fellowship

Winterthur Museum and Estate Research Fellowship

Weston Cate Research Fellowship of the Vermont Historical Society

Stuart and Joyce Robbins Fellowship

Department of History (WVU) Doctoral Dissertation Fellowship

WVU Graduate Office Doctoral Dissertation Fellowship

Wesley M. Bagby (doctoral) Award

Eberly College of Arts and Sciences Incoming Doctoral Student Fellowship

Research Development Grant, WVU

B'nai B'rith Award (for historical studies), 2001 and 2004

Department of History (YSU) Outstanding Essay Award (for historical studies) 


\section{Service}

Rush D. Holt History Conference, program/papers committee chair WVU Department of History, Research and Scholarship Committee WVU Department of History, Graduate Instructor Orientation organizer/presenter National History Day (volunteer/judge) and Ohio Lake-to-River Science Fairs (judge)

Youngstown Board of Education, Writing to Read pilot project and grant writing volunteer

Ohio Association for Gifted Children, Youngstown Chapter, charter member/past president

\section{Affiliations}

Phi Kappa Phi

Phi Alpha Theta

Society for Historians of the Early Republic

Organization of American Historians 